\title{
COPYRIGHT AND THE PUBLIC INTEREST
}

$$
\text { by }
$$

\author{
Gillian Davies
}

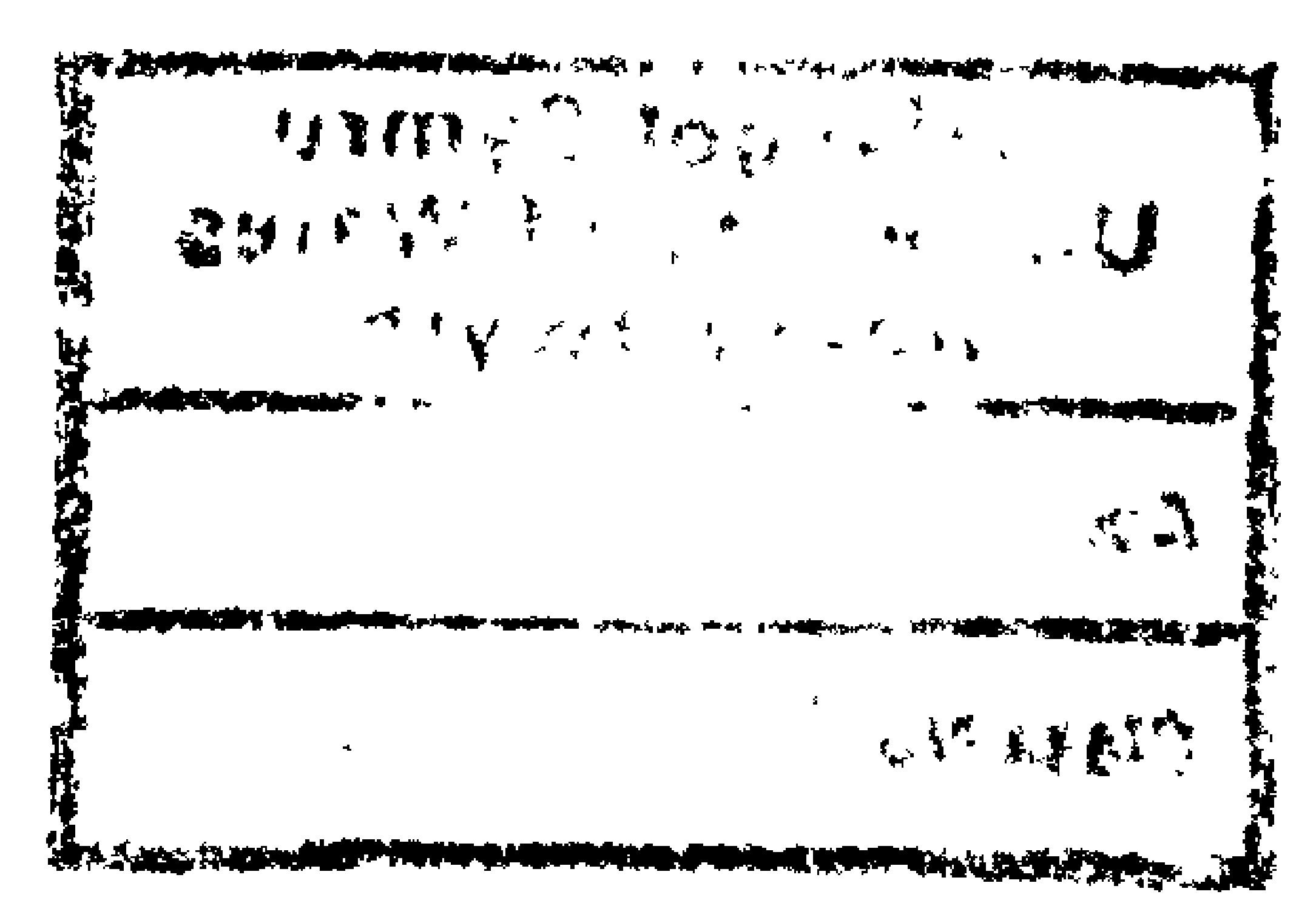


This work has not previously been accepted in substance for any degree and is not being concurrently submitted in candidature for any degree.

Signed $\ldots \ldots \ldots \ldots \ldots \ldots \ldots \ldots \ldots \ldots \ldots \ldots \ldots \ldots \ldots \ldots \ldots$ (candidate)

Date ......7... April . 1997

STATEMENT 1

This thesis is the result of my own investigations, except where otherwise stated.

Other sources are acknowledged by footnotes giving explicit references. A bibliography is appended.

Signed $\ldots \ldots \ldots \ldots \ldots \ldots \ldots \ldots \ldots \ldots$ (candidate)

Date ........... . . 199.7...........

Signed $\ldots \ldots \ldots \ldots \ldots \ldots \ldots \ldots \ldots$ (supervisor)

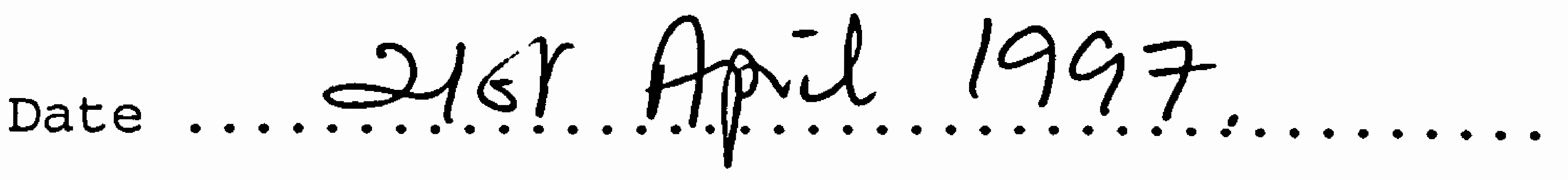

STATEMENT 2

I hereby give consent for my thesis, if accepted, to be available for photocopying and for inter-library loan, and for the title and summary to be made available to outside organisations.

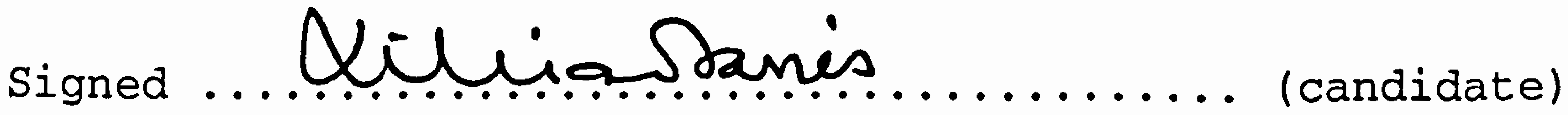

Date ..........Aomil .1997. 
The law of copyright will celebrate its tricentennial in thirteen years time. First introduced in England in 1709 in response to the invention of printing, its history has been one of constant development to keep pace with significant changes in technology. In the 1990s, copyright is more topical than ever. The potential for worldwide distribution of multi-media works over the emerging Global Information Infrastructure is the latest challenge facing the copyright system. This situation has prompted ambitious programmes for copyright reform and harmonisation at national level and within the Berne Union and the European Union. It is timely therefore to reexamine the basic justifications for copyright.

The first two legislative texts on copyright, the UK Statute of Anne 1709 and the Copyright Clause of the US Constitution 1787, embodied the concept that providing copyright protection for authors for a limited time would encourage and promote learning and progress and thus act for the public good.

The thesis explores the underlying principles governing copyright legislation in the light of the proposition that copyright is a just and proper concept, established and developed in the public interest. In recent years, this proposition has been contested in the context of the challenges to the copyright system posed by technical developments. In this debate, the philosophical basis for copyright and its moral and economic functions have been called into question and the public interest has been invoked, not in favour of improved protection for copyright owners, but in favour of free and unfettered access by the public to copyright works.

By reexamining these issues, the thesis aims to contribute to the ongoing debate on public policy in relation to copyright reform and harmonisation. 


\section{The chief glory of every people arises from its authors}

Samuel Johnson 
Preface . . . . . . . . . . . . . . . . viii

$\begin{array}{llll}\text { PART I THE PUBLIC INTEREST IN THE COPYRIGHT SYSTEM } & 1\end{array}$

Chapter 1. Introduction . . . . . . . . . . . 1

Chapter 2. The Underlying Principles Governing

Copyright Legislation . . . . . . . 8

(i) Natural Law . . . . . . . . 12

(ii) Just Reward for Labour . . . . . . 12

(iii) Stimulus to Creativity . . . . . 13

(iv) Social Requirements ........ 14

Chapter 3. Origins of Copyright Law in Europe . . . . 18

PART II THE CONCEPT OF THE PUBLIC INTEREST IN THE HISTORY OF COPYRIGHT - NATIONAL EXAMPLES .

Chapter 4. United Kingdom . . . . . . . . . . . . 24

The Eighteenth Century Debate

on the Nature of Copyright . . . . . . . 24

The Revision Act of 1842 . . . . . . . . 28

The 1878 Royal Commission Report . . . . . 30

The Twentieth Century . . . . . . . . 32

- The 1911 Act ........... . 32

- The 1956 Act . . . . . . . . . . 35

The Public Interest in the Debate for

Reform and the 1988 Act . . . . . . . 36

Post 1988 - Act Developments . . . . . . . 42

The Public Interest and Limitations

on Copyright . . . . . . . . . . . . . 43

- Term of Protection ... . . . . . 44

- Fair Dealing . . . . . . . . . . 46

- Public Interest Defence . . . . . . 48

- Statutory Exemptions in Favour of Education and Libraries . . . . . . 
- Special Regulations Concerning

Libraries and Archives . . . . . 51

- Other Statutory Defences . . . . . 52

Conclusion . . . . . . . . . . . 52

Chapter 5. The United States of America . . . . . . . 62

Origins of the 1790 Act . . . . . . . 62

Legislative Developments between

1790 and 1976 ............ . 65

- 1790-1909............. 65

- The Long Road to Reform and

the 1976 Act . . . . . . . . . 66

- Recent Developments . . . . . . 68

The Underlying Philosophy in the

US Law of Copyright . . . . . . . . 72

The Public Interest and Limitations

on Copyright . . . . . . . . . . 75

- Term of Protection . . . . . . 75

- Fair Use . . . . . . . . . . 79

- Statutory Exceptions to Protection . 82

Conclusion .. . . . . . . . . . . 84

Chapter 6. France . . . . . . . . . . . . 93

Origins of the Law . . . . . . . . . 93

The Revolution and the Decrees of

1791 and 1793 . . . . . . . . . . . 98

- The Performance Right . . . . . . 99

- The Reproduction Right . . . . . 101

The Development of the Law between

1793 and 1957 . . . . . . . . . . . 103

- Legislation . . . . . . . . 103

- Case Law . . . . . . . . . 106

- Exceptions .. . . . . . . . 107

- Moral Rights . . . . . . . . 107

- Proposals for Reform in the Nineteenth Century - Perpetual Rights versus the Public Interest . . . . . . . . 108

- The Evolution of French Concepts of Authors' Rights . . . . . . . 110 
The Twentieth Century

- The Road to Reform:

The Draft Law of 1945

- The 1957 Law on Literary and Artistic Property . . . . . . . . . . .

- The Public Interest in the Debate for Reform and the 1985 Law . . . . . 117

- Statutory Exceptions to Protection - 120

- Recent Developments . . . . . . 120

Conclusion

Chapter 7. Germany . . . . . . . . . . . 133

Origins of the Law . . . . . . . . . 133

Legislative Developments: 1870-1901 . . . 137

The Twentieth Century . . . . . . . . 139

- 1901-1949............ . 139

- 1949-1965 ............. 144

- The 1965 Act . . . . . . . . . 148

The Public Interest and Article 14 of the Basic Law . . . . . . . . . . . . 151

Subsequent Amendments to the 1965 Act . . . 157

- The 1972 Amendment . . . . . . 157

- The Amendment Act 1985 . . . . . 158

- Follow-up to the 1985 Act . . . . . 160

- Recent Developments . . . . . . 162

Conclusion .............. . 164

PART III COPYRIGHT AND PUBLIC POLICY . . . . . . . 172

Chapter 8. Introduction . . . . . . . . . . . 172

Chapter 9. The Functions of Copyright Revisited . . . 177

Chafee's Six Ideals of Copyright . . . . . 177

The Moral Justifications for

Copyright Revisited . . . . . . . . 180

The Economic Justifications for

Copyright Revisited . . . . . . . . 182

Alternatives to Copyright . . . . . . . 187 
Chapter 10. Limitations on Copyright . . . . . . . 197

Duration of Protection . . . . . . . 197

Exceptions to Protection ........ 206

- Free Fair Use . . . . . . . . . 206

- Non-Voluntary Licensing Systems . . 207

- Private Use and Modern Technology . . 208

The Exercise of Rights . . . . . . . . 211

Chapter 11. Conclusions . . . . . . . . . . 220

Appendices

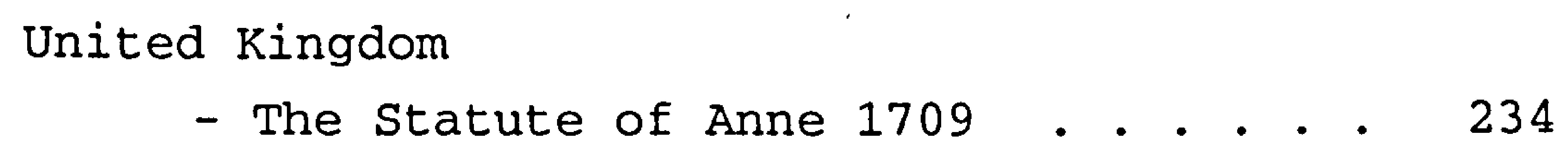

- The Statute of Anne 1709 . . . . . 234 U.S.A.

- Copyright Act 1790 . . . . . . . 241 France

- Décret des 13-19 janvier 1791 relatif aux spectacles ..... . 245

- Décret des 19-24 juillet 1793 . . . 245 Germany

- Preußisches Gesetz zum Schutze des Eigent/hums an Werken der Wissenschaft und Kunst gegen Nachdruck und Nachbildung vom 11. Juni 1837 . . . 247

Bibliography . . . . . . . . . . . . 259 


\section{PREFACE}

Throughout its near three-hundred year history, the law of copyright has been closely linked to developments in technology. First introduced in England in 1709 in response to the invention of printing, copyright law has been adapted continually to technological change, as new works and new uses of works have resulted from technical progress. During the present century, this process has accelerated to accommodate the advent of the film, sound recording, radio, television, cable and satellite broadcasting, computer technology and advances in copying techniques. In the 1990s, these developments have been compounded by the use of computer technology to digitise works in combination with new digital distribution and communication technologies. The potential for distribution of multi-media works on a global scale over the emerging Global Information Infrastructure is the latest challenge facing the system.

This situation has prompted ambitious programmes for copyright reform and harmonisation at national level and within the Berne Union for the Protection of Literary and Artistic Works and the European Union. At present, copyright is more topical than ever and it is timely, therefore, to reexamine the basic justifications for copyright.

The first two legislative texts on copyright, the UK Statute of Anne 1709 and the Copyright Clause of the US Constitution 1787, embodied the concept that providing copyright protection for authors for a limited time would encourage and promote learning and progress and thus act for the public good.

The thesis discusses the proposition that copyright is a just and proper concept, established and developed in the public interest, and explores the extent to which the notion of the public interest has influenced the copyright laws of a few major jurisdictions, namely, France, Germany, the United Kingdom and the United States of America from their origins in the eighteenth century to date. 
The proposition that copyright is in the public interest has been taken for granted in the past but, in recent years, it has been contested in the context of the challenges to the copyright system posed by the technical developments referred to above. In this debate, the underlying philosophy of copyright and its moral and economic functions have been increasingly called into question and the public interest has been invoked, not in favour of strengthening the protection afforded to copyright owners, but in favour of free and unfettered access by the public to copyright works.

By examining the underlying principles which have governed the copyright system from its origins, the study also draws attention to the fact that the roots of European and US copyright shared a common approach and that, contrary to the prevailing opinion that the Continental European and Anglo-American approaches to copyright are diametrically opposed, historical analysis shows that there is in fact a rich tradition of consensus as regards the justifications for and legislative solutions to copyright on which to draw during the harmonisation process.

The thesis is presented in three parts. Part I provides an introduction to the concept of the public interest in the copyright system and explores the underlying principles governing copyright legislation, as well as its origins in Western Europe. Part II reviews the concept of the public interest in the history of copyright in the United Kingdom, the United States of America, France and Germany. Part III deals with copyright and public policy, considering the moral and economic functions of copyright in relation to the alternatives thereto, the limitations imposed on copyright in the public interest and, finally, draws some conclusions in relation to the public policy role of the state in maintaining the copyright system. 
The thesis is a revised and updated version of a study by the author first published in $1994^{1}$ in Germany under the auspices of the Max Planck Institute for Foreign and International Patent, Copyright, and Competition Law, Munich, which provided her with the opportunity to begin research on this study.

Munich, 31 October 1996

Gillian Davies

1 Davies, G., Copyright and the Public Interest, Volume 14 IIC Studies in Industrial Property and Copyright Law, Max Planck Institute for Foreign and International Patent, Copyright and Competition Law, Munich, Weinheim; New York, NY; VCH 1994. 


\title{
PART I THE PUBLIC INTEREST IN THE COPYRIGHT SYSTEM
}

Chapter 1: Introduction

\begin{abstract}
The system of copyright has great advantages and great disadvantages, and it is our business to ascertain what these are, and then to make an arrangement under which the advantages may be as far as possible secured, and the disadvantages as far as possible excluded.'

T. Macaulay
\end{abstract}

The purpose of this study is to discuss the proposition that copyright $^{2}$ is a just and proper concept, established and developed in the public interest and to explore the extent to which the notion of the 'public interest' has influenced the copyright laws of a few major jurisdictions from their origins in the eighteenth century to date. In this context, the basic justifications for copyright and the public policy role of the state in relation to copyright are examined, with particular reference to the challenges to the modern copyright system posed by technical developments.

"When considering the public interest ... it is to be remembered that one feature ... is that justice should always be done and should be seen to be done." ${ }^{3}$ The concept of pro bono publico is Roman: according to Cicero, "The good of the people is the chief law." 4

Whether a particular act is 'in the public interest' is probably not subject to any objective tests. Inherent in the noble motive of the public good is the notion that, in certain circumstances, the needs of the majority override those of the individual, and that the citizen should relinquish any thoughts of self-interest in favour of the common good of society as a whole. Milton expressed this principle cogently:

"That grounded maxim

So rife and celebrated in the mouths

of wisest men; that to the public good

Private respects must yield." 5 
The first two important legislative statements on copyright, the English Statute of Anne $1709^{6}$ and the copyright clause of the American Constitution, framed in 1787, both address the public interest issue. The statute of Anne is described as "an Act for the encouragement of learning, by vesting the copies of printed books in the authors or purchasers of such copies, during the times therein mentioned."

The Preamble gives three main motivations for the legislation. First, to prevent for the future the printing and publication of "books and other writings, without the consent of the authors or proprietors of such books and writings," that is, to outlaw the pirate trade in books. Second, by preventing piracy to remedy a practice seen as being to the "very great detriment" of authors, leading "too often to the ruin of them and their families." Third; "for the encouragement of learned men to compose and write useful books." The copyright clause of the US Constitution vests Congress with the power "to promote the progress of science and useful arts, by securing for limited times to authors and inventors the exclusive right to their respective writings and discoveries." 7

These two statements embody the concept that providing protection for the author against unauthorised publication for a limited period will encourage and promote learning and progress and thus act for the public good.

The copyright system as we know it today is still built on these early foundations. The premise is accepted that creating is worthwhile and that copyright provides a means of giving creators what is properly due to them, thereby stimulating cultural activity, a result which cannot be other than for the common good.

National laws are only enacted if they are in the public interest, or at least it must be assumed that the enacting body so regards them. "Those who govern must act as if they were defending the public good, the general interest; it is even useful that they should believe it, because faith strengthens 
conviction".$^{8}$ Moreover, "Copyright is an instance in which the public good fully coincides with the claims of individuals". Certainly, this has been the consistent view of the British throughout the past 200 years, as the following quotations from Macaulay speaking in 1841 and from the Whitford Committee's report in 1977 demonstrate.

"The advantages arising from a system of copyright are obvious. It is desirable that we should have a supply of good books; we cannot have such a supply unless men of letters are liberally remunerated and the least objectionable way of remunerating them is by way of copyright." 10

"The exclusive rights which are granted by national copyright, patent, trademark and design laws are granted because it is in the public interest to grant them." ${ }^{11}$

Over 130 countries have enacted copyright laws. The Berne Convention for the Protection of Literary and Artistic Works has 117 member States (as of 1 January 1996) and the Universal Copyright Convention has 95 members (as of the same date). This confirms the fact that there is virtually universal agreement that the copyright system is indeed in the public interest. In the course of the 20th century, many nations have subscribed to the Universal Declaration of Human Rights (United Nations 1948) and/or the International Covenant on Human Rights (League of Nations 1919). These two documents provide, inter alia, for the protection of authors' rights in Art. 27(2) of the former and Art. 15(1) of the latter. They confirm the consensus that the copyright system has a significant part to play in stimulating worldwide cultural activities for the mutual benefit of those who create, and those who enjoy the fruits of that labour.

The proposition that copyright is in the public interest is mostly taken for granted. References to the issue are scarce in the literature. However, in recent years, the proposition has been questioned in the context of the challenges posed to the copyright system by technical developments. These challenges are proliferating year by year in the present period of rapid 
technological change. In the 1970s and 1980s they included: advances in copying techniques which led to unauthorised reproduction of copyright works on an unprecedented scale; new uses of works made possible by new technology such as video production, satellite transmission and cable distribution; the creation and production of new categories of works, such as, e.g. computer programs, data bases and multi-media works. In the $1990 \mathrm{~s}$ these developments have been compounded by the use of computer technology to digitise works in combination with new digital distribution and communication technologies. The potential for distribution of multi-media works on a global scale over the emerging Global Information Infrastructure made available by a combination of computer, telephone, satellite and cable technologies is the latest challenge facing the copyright system.

As a result, the copyright system has been labouring for the past two decades under considerable strain and has attracted the attention not only of legislators, called upon by the interested parties to update and improve the level of protection provided to right owners in their national laws, but also of economists and academics. In this debate, the underlying philosophy of copyright and its basic functions have been called into question and the public interest has been invoked, not in favour of strengthening the protection afforded to authors and other right owners, but in favour of free and unfettered access by the public to copyright works.

The copyright system as it has developed over the past nearly three hundred years, has created, in the public interest, a balance between the rights of the authors, on the one hand, and the interest of the public in access to protected works, on the other. From the inception of copyright law, rights have been subject to limitations of duration and exemptions for personal and scientific use. This balance has been expressed in Art: 27 of the Universal Declaration of Human Rights which provides:

(i) Everyone has the right freely to participate in the cultural life of the Community, to enjoy the arts and to share in scientific advancement and its benefits; 
(ii) Everyone has the right to the protection of the moral and material interests resulting from any scientific, literary or artistic production of which he is an author.

Thus, copyright systems are recognised as having a two-fold purpose: to accord exploitation rights to those engaged in literary and artistic production and to answer to the general public interest in the widest possible availability of copyright material.

In assessing the balance between these two apparently conflicting purposes, so as to ensure the protection of the individual and the public, different Governments have adopted varying approaches to the questions: "What is fair?" and "What rights and limitations are required?"

These differences reflect the different emphases placed in different parts of the world on the several basic principles underlying copyright. "The very concept of copyright from a philosophical, theoretical and pragmatic point of view differs country by country, since each has its own legal framework influenced by social and economic factors." 12

The emphasis placed on the relationship between copyright law and the public interest also differs.

This study explores, first, the underlying principles governing copyright legislation internationally and the origins of copyright law in Western Europe; second, the importance attributed to the concept of the public interest in the history of the copyright laws of the United Kingdom, the United States of America, France and Germany, in that order. As a matter of history, that is the order in which the respective states first legislated on copyright. Thirdly, issues related to copyright and public policy are examined, including the moral and economic functions of copyright, the alternatives to copyright and the nature and extent of the limitations imposed on copyright. In the discussion of these issues, the various arguments and theories are tested against the yardstick of the principles laid down in the six ideals of copyright law postulated by Professor Zechariah 
Chafee in his seminal article published in 1945 and entitled "Reflexions on the Law of Copyright". ${ }^{13}$ In conclusion, the public policy role of the state in maintaining the copyright system is considered. 
Hansard, Vol. 56, 5 February 1841, at 346 (T. Macaulay).

Throughout this study, the word 'copyright' is used in its widest sense as a generic term to describe the various systems of law, which in 1996 protect authors of literary, artistic and musical works and other right owners, such as performers, film producers, producers of phonograms (sound recordings) and broadcasting organisations. Evidently, in the discussion of the history of copyright it is authors of literary, artistic and musical works, as well as publishers, with whom we are mainly concerned. There are two basic approaches to the protection of the various categories of copyright owners. The system of 'droits d'auteur' (author's rights), based on the protection of the individual author, and that of 'copyright,' which admits protection both of individuals and of corporate bodies and thus permits a wide variety of creative endeavour to share the umbrella of copyright. The 'droit d'auteur' system as a general rule affords protection only to individual authors; others, such as performers, producers of phonograms and broadcasting organisations, are protected by means of related, sometimes called neighbouring rights ('droits voisins'). Copyright systems do not make the same distinction.

This study does not deal in any detail with these distinctions, being concerned with the broad concept of copyright. However, for the sake of clarity, where in this study author's rights, in particular, as opposed to copyrights in general, are referred to, the term 'author's rights' is used. Likewise, the term 'droit d'auteur' is translated as author's right.

Per Morris, L J (Ellis $v$ Home office 1953, 2QB 135).

De Legibus III, iii.8.

Samson Agonistes, line 865.

The Statute of Queen Anne, 1709, Chapter XIX (see p. 234 of this study). This was the first parliamentary English Copyright Act and the first without provision for censorship.

7 United States Constitution, Article I, 8, cl. 8.

8 Recht, Pierre, Copyright, a New Form of Property, 1969 Copyright 94.

9 Madison, James, quoted in: Goldstein, Paul, Copyright Principles, Law and Practice (Little Brown and Company, 1989), at 5, n. 2 .

Macaulay, T. in: Hansard, 10c. cit., supra, n. 1.

Copyright and Designs Law, Report of the Committee to consider the Law on Copyright and Designs, Chairman - The Honourable Mr Justice Whitford, March 1977, HMSO, Cmnd 6732, para. 84.

Masouyé, Claude, Guide to the Berne Convention (WIPO, March 1978), para. 1.15 .

13 Chafee, Zechariah: Reflexions on the Law of Copyright, 45 Columbia Law Rev. 503 and 719 (1945). 
Chapter 2: The Underlying Principles Governing Copyright Legislation

"What is its history - its judicial history? It is wrapt in obscurity and uncertainty." Judge Joseph Hopkinson ${ }^{1}$

The development of the modern copyright system has been referred to as being

due in no small measure to the confusion of ideas resulting from the events in eighteenth century England, ... The ideas - that copyright is a monopoly; that copyright is primarily an author's right; that the author has natural rights in his works which must be limited by statute - once stated by the courts, became a fixed part of the heritage of copyright. ${ }^{2}$

It is important to begin an examination of the underlying principles governing copyright legislation with the eighteenth century English Statute of Anne because it is the foundation upon which the modern concept of copyright in the Western World was built. "In changing the conceptual nature of copyright, it became the most important single event in copyright history. Two of the principles on which it rests were revolutionary: recognition of the individual author as the fountainhead of protection and adoption of the principle of a limited term of protection for published works." ${ }^{3}$ Or as Barbara Ringer has put it more colourfully, the statute of Anne is "the mother of us all and a very possessive mother at that". "It is important also to note that it was not the first English statute to deal with copyright but the first to be adopted by Parliament as opposed to royal decree and the first to be unconnected with censorship. ${ }^{5}$

Prior to the Statute of Anne, from the early 16th century onwards, in England and elsewhere in Europe, 'privileges' had been granted by the sovereign to booksellers following the invention of printing, to regulate the book trade and to protect printers against piracy. These privileges were in time used as an instrument of censorship by the authorities. From 1557, in England, privileges were the monopoly of members of the Stationers' Company. The royal interest in granting the monopoly was not to provide protection to the stationers' property rights 
but to satisfy the desire of the crown for an effective control over the publishing trade and the press so as to outlaw the publishing of seditious and heretical books. 6

The system of privileges was abolished with the Cromwellian Revolution. Privileges had derived their authority from the Crown and, along with the King's authority, were set at nought. They were replaced by a series of Parliamentary ordinances. These prohibited printing unless the book was first licensed. Printing was prohibited without the consent of the owner. In 1662 , the Licensing $\mathrm{Act}^{7}$ was passed which prohibited the printing of any book unless first licensed and entered in the register of the stationers' Company. It also prescribed regulations as to printing and outlawed books suspected of containing matters hostile to the church or Government. The Act further prohibited any person from printing or importing, without the consent of the owner, any book which any person had the sole right to print. The penalty for piracy was forfeiture of the books and a fine to be paid half to the king and half to the owner. Thus, "The sole property of the owner is here acknowledged in express terms as a common law right. " ${ }^{8}$ The Act of 1662 was continued by several Acts of Parliament but expired in 1679. The system had fallen into disrepute because the power of members of the stationers' Company to claim copyright in perpetuity had led to high prices and a lack of availability of books. The control of the book trade exercised by the stationers' Company was broken with the result that book piracy flourished.

Parliament was regularly petitioned, therefore, for a new Licensing Act. The booksellers argued that failure to continue exclusive rights of printing had resulted in disincentives to writers. Without some form of protection to encourage authors, the public interest would be harmed by the decreased flow of works. 9 To the entreaties of members of the stationers' Company was added in 1690 the voice of the philosopher, John Locke, who, although opposed to licensing as leading to unreasonable monopolies injurious to learning, "demanded a copyright for authors which he justified by the time and effort expended in the writing of the work which should be rewarded like any other 
work." He also advocated limiting the term of protection to a period of from 50 to 70 years after the death of the author. ${ }^{10}$

In response, the Statute of Anne was passed in 1709 and came into force on 10 April 1710. The Act, adopted, as we have seen from the Preamble, for the encouragement of learning, simultaneously sought to satisfy:

(i) the demands of the Stationers' Company by restoring to them the sole right to print books then printed for a period of 21 years;

(ii) the demands of authors and their assigns for recognition of their sole right to print books not yet printed, published or "that shall hereafter be composed" for a term of 14 years from the date of publication. After the expiration of the 14-year term, the sole right of printing or disposing of copies returned to the author, if living, for another term of fourteen years. Thus the statutory copyright was not to be limited to the members of the Guild, and it was not to exist in perpetuity.

(iii) the public interest in the supply of cheap books by providing that "if any bookseller or booksellers, printer or printers, shall ... set a price upon, or sell, or expose to sale, any book or books at such a price or rate as shall be conceived by any person or persons to be too high and unreasonable; it shall be and may be lawful for any person or persons, to make complaint thereof" to the Archbishop of Canterbury, Lord Chancellor (or to a number of specified dignitaries of church and bench) who were given powers to enquire into the price and "to limit or settle the price of every such printed book ... according to the best of their judgements. "11

Title to the copy of a book had to be registered before publication with the stationers' Company and nine copies had to be delivered for the use of certain libraries. 
Penalties for infringement were severe: infringing books were subject to forfeiture and a fine of a penny for every sheet copied. This resulted in a steep fine when many copies of a substantial book were pirated. The fine was divided equally between the Crown and the complainant.

An interesting additional feature is that the Act expressly provided that the importation and sale of books in Greek and other foreign languages printed "beyond the seas" should remain unaffected by its provisions.

It is apparent then that this, in historical terms, first copyright law, responded to several objectives. Its stated purposes were to be for the encouragement of learning, for preventing the practice of piracy for the future, and for the encouragement of learned men to compose and write useful books.

To achieve these objectives, it sought to break the perpetual monopoly of the booksellers and printers of the stationers' Company over the book trade. It recognised for the first time a right of the author to control the publishing and printing of his work and the interest of the author himself, as well as his assigns, to be protected against piracy. It gave a nod to the natural rights of authors by recognising that piracy was not only "to their very great detriment" but also "too often to the ruin of them and their families." Yet it also sought to provide the public with a supply of "useful" books at cheap prices.

The Act was a compromise between the demands of the publishers and what Parliament considered the public interest ... the legal monopoly which the printers had in perpetuity was broken but they were still left in a strong position. The character of the Act is that of a Trade Regulation, but the law nevertheless recognised that the source of the copyright is the work created by the author. ${ }^{12}$

In this Act, therefore, are found the seeds of the underlying principles on which the modern international copyright system is founded. 
These principles have been described under four main headings: ${ }^{13}$

(i) natural law

(ii) just reward for labour

(iii) stimulus to creativity

(iv) social requirements

\section{(i) Natural Law}

The rights of the author over his work are considered as embodied in natural law, inherent in the "very nature of things." ${ }^{14}$ He is the creator of the work; it is an expression of his personality and the fruit of his mind. The natural law of property was propounded by Locke. ${ }^{15}$ Starting from the premise that people had a natural right of property in their bodies, he argued that people also owned the labour of their bodies and the results of that labour. It followed that the author has an exclusive natural right of property in the results of his labour and should have control over the publication of his work as well as the right to object to any unauthorised modification or other attack on the integrity of his work. "It is just, that an author should reap the pecuniary profits of his own ingenuity and labour. It is just, that another should not use his name, without his consent. It is fit that he should judge when to publish, or whether he ever will publish." ${ }^{16}$

\section{(ii) Just Reward for Labour}

"It is certainly not agreeable to natural justice, that a stranger should reap the beneficial pecuniary produce of another man's work." 17

If it is accepted that creating is worthwhile, be it art, music, literature or other work and that the fruits of such labour enrich our lives, then the authors deserve to be remunerated when their work is exploited. Remunerating a creator for the use of his work enables him to continue working and is natural justice in accord with the maxim that the labourer is worthy of his hire. 
After all, in Dr Johnson's view, "no man but a blockhead ever wrote except for money". ${ }^{18}$

The author is thus entitled to economic rewards. As the US Supreme Court stated in 1954, "Sacrificial days devoted to ... creative activities deserve rewards commensurate with the services rendered." 19

Moreover, today, copyright provides the economic basis for investment by the cultural industries in the creation, production and dissemination of works and other protected subject-matter.

In the modern world considerable investment is needed to make the creation of some works, such as works of architecture or films, possible. As the purpose of the creation of practically all works is to make them available to the public, that process too, such as publication and distribution of books or records, is expensive. These investments will not be made unless there is a reasonable expectation of recouping them and making a reasonable profit. ${ }^{20}$

\section{(iii) Stimulus to Creativity}

Just reward for labour provides a stimulus to creativity; thus, these two basic principles of copyright are inextricably linked.

As we have seen, the UK Statute of Anne and the copyright clause in the American Constitution both laid emphasis on the role of copyright protection in the stimulation of creativity. A stated aim of the English law was the "encouragement of learned men to compose and write useful books". The US Constitutional clause aimed "to promote the progress of science".

"Copyright law presupposes that, absent subsidy, authors and publishers will invest sufficient resources in producing and publishing original works only if they are promised property rights that will enable them to control and profit from their work's dissemination in the marketplace". ${ }^{21}$

"Take away from English authors their copyrights, and you would very soon take away from England her authors". ${ }^{22}$ 
"It is important to emphasise that the main purpose of copyright protection must be to stimulate the production of intellectual works" . ${ }^{23}$

Like most other observers, I am irrevocably convinced that the facilities which copyright affords for the remuneration of intellectual creativity stimulates creatively gifted people to go in for activities of this kind. As far as I can judge, the thesis of all creativity being the exclusive result of inward compulsion is untenable. Very often a person has to choose between artistic activity and some other means of gaining a livelihood. If the economic proceeds of artistic activity were not assured, the choice would often fall in the other direction. ${ }^{24}$

\section{(iv) Social Requirements}

"The social usefulness of copyright consists in providing an economic basis for creation". ${ }^{25}$

It is a social requirement in the public interest that authors and other right owners should be encouraged to publish their works so as to permit the widest possible dissemination of works to the public at large. "If the ideas and experiences of creators can be shared by a wide public within a short space of time they contribute to the advance of society" ${ }^{26}$

"The sole interest of the United States and the primary object in conferring the monopoly lie in the general benefits derived by the public from the labors of authors". ${ }^{27}$

One has come to realise that in the final analysis the protection of copyright leads to the enrichment of the national cultural patrimony; that the higher the level of protection the more authors are encouraged to create and, in consequence, to expand the literary and artistic influence of their respective countries; that the more intellectual creations there are, the greater the extent to which the entertainment industry, and the book and recording industries, etc., which are the essential partners of authors, are encouraged to establish themselves and grow. ${ }^{28}$

These four fundamental principles are, of course, cumulative and interdependent. They are applied in the justification of copyright in all countries, although different countries give varying emphasis to each of them. To generalise, it is true to say that, in the development of modern copyright laws, the economic and social arguments are given more weight in the 
Anglo-american laws whereas, in Continental law countries, the natural law argument is to the fore.

These differences in approach, common law copyright, with its emphasis on protection of the work with a view to encouraging authors to create and disseminate their works, and the civil law author's right, which puts the protection of the author in relation to his rightful property in the first place, are illustrated by the national accounts of the development of the copyright laws in Part II with respect to the United Kingdom, the United States of America, France and Germany. The natural law justification for copyright has had particular influence on the concept and development of moral rights. The differences should not however be exaggerated and as this study shows there is much common ground in the historical and present-day justifications for copyright in the common law and civil law countries. ${ }^{29}$ 
1 Per Circuit Judge Joseph Hopkinson in the lower court opinion in the landmark US case of Wheaton $V$ Peters, 29 Fed. Cas. 862, 871 (n. 17486) (C.C.E.D.Pa 1832).

Patterson, L. Ray, The Statute of Anne: Copyright Misconstrued, 3 Harv. J. Legis 223 (1966).

3 Halsbury's Laws of England, fourth edition, Lord Hailsham of St. Marylebone, Vol. 9, Butterworths, London, 1974

4 Paper delivered at WIPO seminar, Montreux, 1971.

5 Earlier Star Chamber Decrees, censorship ordinances during the Interregnum and the Licensing Act of 1662 were copyright as well as censorship Acts.

6 The preamble of the Stationers' Company charter reads as follows: "Know ye that we, considering and manifestly perceiving that certain seditious and heretical books rhymes and treatises are daily published and printed by divers scandalous malicious schismatical and heretical persons, not only moving our subjects and leiges to sedition and disobedience against us, our crown and dignity, but also to renew and move very great and detestable heresies against the faith and sound catholic doctrine of Holy Mother Church, and wishing to provide a suitable remedy in this behalf."

Licensing Act 1662 (13\& 14 Car. 2 c.33).

8 Copinger and Skone James on Copyright, Including International Copyright with the Statutes, Orders, Conventions and Agreements thereto relating and precedents and court forms also related forms of protection (Sweet \& Maxwell, 13th ed. 1991), para. 1.25.

9 Patterson, L., Copyright in Historical Perspective, Nashville, Vanderbilt University Press, 1968, at 142.

10 Locke, John, Two Treatises of Government (1690), edited by: Laslett, Peter, Cambridge University Press, 1988, \$27. And see Locke, John, Memorandum to Edward Clark, cited in Rose, Mark, Authors' and Owners, the Invention of Copyright, Harvard University Press, 1994, at 32, 33.

11 The Statute of Queen Anne, 1709, Chapter XIX, Section IV (see p. 236 of this study)

Patterson, The Statute of Anne, n. 2 supra, op. cit., at 13.

13 Stewart, S.M., International Copyright and Neighbouring Rights Butterworths, London, 1983, at 22 .

Kase, J. R., Copyright Thought in Continental Europe (1971), at 8.

J. Locke, The Second Treatise of Civil Government $\S 27$, in Two Treatises of Government, op.cit.: "Whatsoever then he removes out of the state that Nature hath provided, and left it in, he hath mixed his Labour with, and joyned to it something that is his own, and thereby makes it his Property. It being by him removed from the common state Nature placed it in, it hath by his Labour something annexed to it, that excludes the common right of other Men. For this Labour being the unquestionable Property of the Labourer, no Man but he can have a right to what that is once joyned to, at least where there is enough, and as good left in common for others". On the natural law and copyright, see Yen, Alfred $C_{\text {. }}$, Restoring the Natural Law: Copyright as Labor and Possession, 51 Ohio State Law Journal, No. 2 (1990). For a discussion of the purpose of copyright including the Lockean justification therefor, see also Friedman, Barbara, From 
Deontology to Dialogue: The Cultural Consequences of Copyright, 13 Cardozo Arts and Entertainment (1994) 157.

16 Millar $v$ Taylor, per Lord Mansfield, 4 BURR. 2334, at 252 .

17 Ibid., per Mr Justice Willis, at 218.

18 Boswell, Life of Johnson (L. F. Powell's revision of G. B. Hill's edition), at 19,5 April 1776.

19 Mazer $v$ Stein, 347 US 201, 219.

20 Stewart, op. cit., para. 1.03.

21 Goldstein, Paul, Copyright Principles, Law and Practice (Little Brown and Company, 1989), para. 1.1.

Trollope, A., Autobiography, Chapter 6 .

23 Ljungman, S. Nogot om Verkshöjd, 1972 NIR 35.

24 Ljungman, S., The Function of Copyright in Present Day Society: Some Reflections with Reference to the Nordic Situation, 88 RIDA 51, 65 (1976).

25 Kerever, André, Is Copyright an Anacronism, 1983 Copyright 368.

Stewart, op. cit., para. 1.05.

27 Chief Justice Hughes in Fox Film Corp. V Doyal, 286 US 123, 127.

28 Masouyé, Claude, Droit d'auteur: Horizon 2000, 1979 Il Diritto di Autore 163 (author's translation).

29 On the nature and extent of these divergencies and the impact of international harmonisation measures thereon, see Davies, Gillian, The Convergence of Copyright and Authors' Rights - Reality or Chimera?, 26 IIC 964 (1995). 
Chapter 3: Origins of Copyright Law in Europe

"Copyright is a beast of substantial historical ancestry". Sheldon N. Light ${ }^{1}$

Thus far, we have looked primarily at the origins of copyright law in England for the reason that England was the first country to legislate on the subject. Before examining the legislative history in relation to the public interest of individual countries, it may be useful briefly to contrast the origins of copyright law in Continental countries with the situation in England. ${ }^{2}$

The invention of the printing press led to the introduction of printing in Europe in the late fifteenth and early sixteenth centuries. The possibility to print multiple copies of books cheaply resulted in a new market for books for a public who previously had not had access to the manuscripts available in the past only to the most privileged members of society. Printers and publishers made substantial investments; they acquired works from authors (or republished classics which they edited or translated anew) and presses and paper were expensive. "These first printers were and had to be men of great learning and ingenuity. They either wrote or translated most of the material they produced. They built their own presses, cut their own type, made the incidental parts and bound their own works." 3

The printers and publishers soon formed themselves into powerful guilds and petitioned the authorities for protection against unfair competition from printers who copied their editions. Unfettered competition, with freedom for any printer to copy another's editions, led in all the major European countries to a situation in which "piracy was born, so to speak, with the art itself." 4

In this situation, a pattern emerged all over Europe. Exclusive privileges were granted to printers and publishers by national authorities to print certain works or a number of works. 5 In every country, the authorities' interest was the same: to control 
the book trade which represented a new method of making information available to the people and to encourage a new industry. Moreover,

It did not take the authorities long to realise that by restricting the rights to privileges, which were granted only to a small number of people, they could control all publications quite easily ... and this gave the Governments an easy and effective weapon allowing them to exercise a very tight censorship over this new medium. ${ }^{6}$

The period of privileges lasted longer on the Continent than in England. In Germany, the first privilege was granted in 1501 (the earliest privilege in England dated from 1518) and the system was not entirely abolished until the first German copyright law was adopted following the creation of the German Empire in 1871. From 1832, the Alliance of German states had provided for reciprocity in respect of the protection of privileges, and certain minimum standards were agreed upon in 1837. Privileges were granted originally by the Heads of the Lander with effect for the various German states and by the Kaiser with effect for the German Reich. They were awarded to printers and publishers as in England but, according to Ulmer and von Rauscher: "It has become apparent from more recent research into copyright law that they were also granted in a number of cases to authors".?

In France, privileges dated from the early-sixteenth century and the system continued until abolished in the Revolution of 1789 . The first privileges were granted to printers in 1507 and 1508 and "the Crown found the further advantage of censorship in the exclusive right to print and publish, but no interest was shown in the rights of the author". ${ }^{8}$

Modern copyright systems derive three basic features from the privileges: the exclusive rights of reproduction (printing) and distribution (publication) and the fact that privileges were limited in time. ${ }^{9}$ Remedies included seizure and forfeiture of infringing copies as well as fines. In some cases, remedies were more drastic. In France, under an Ordinance of 1566, the penalty for infringement was death by hanging or strangling. 
"In all of this, the role and status of the author was minimal"." Ricketson suggests two main reasons for this: first, that in the early days of printing, most of the books published were old or classical texts; second, that authors still looked to patronage for their chief source of income.

The author owned the manuscript, but was dependent on the printers and booksellers if he wished to communicate his work to the new reading public. The printers bought manuscripts outright. However, from 1642 onwards in England, the publisher had to have the author's consent to print and to use his name ${ }^{11}$. However,

right of copy was the stationer's not the author's. Living authors furnished some of the material for the printing mills, and, increasingly, these manuscripts had to be purchased in a business way (usually payment was made in a lump sum); but upon entry the author dropped away and it was the stationer who had the right of multiplication of copies...12

Authors complained, but by all accounts were more concerned with what are now called moral rights (a late nineteenth-century concept introduced into the Berne Convention at the Rome Revision Conference in $1928^{13}$ and only gradually incorporated in national legislation subsequently), objecting to publication without consent, false attribution of authorship and modifications to the text which were harmful to their reputation. Wittenberg gives a number of examples of such complaints from English authors, including the following heartfelt attack by one George Wither, an English author, in 1625:

For many of our moderne booksellers are but needlesse excrements, or rather vermine, ... yea, since they take upon them to publish bookes contrived, altered and mangled at their own pleasures, without consent of the writers; and to change the name sometymes, both of booke and author (after they have been ymprinted).

Stewart also gives examples of the concern of authors with their moral rights, including that of Martin Luther's complaint to the Council of Nuremberg that his works had been published in altered and amended form. ${ }^{15}$ 
The transition from the system of privileges to copyright in Western Europe took over a century. The gradual end of absolute monarchy led inexorably to the end of privileges. As Kerever tells us:

All the States of Western Europe experienced a changeover in that the effect of the law was to replace the sovereign by the author himself as the source of the right to prohibit unlawful copies, whereby the right was transferred to the publisher under a contract. This changeover was far from simultaneous. ${ }^{16}$

The English Statute of Anne came first in 1709. Denmark and Norway adopted an ordinance in 1741 and Spain a law in 1762. The French revolutionary decrees of 1791 and 1793 came next. Copyright for publishers was first recognised in the Prussian Code of 1794 but authors were not to obtain rights of their own in Prussia until 1837. Privileges were not replaced by copyright in the various Italian states until early in the nineteenth century, for example, Milan in 1810 and the Two Sicilies in 1811. Following the unification of Italy, a law on copyright was adopted in $1865 .{ }^{17}$ 
Light, Sheldon N., Parody, Burlesque and the Economic Rationale for Copyright, 11 Connecticut Law Review, No. 4, 615 (1979).

2 This brief summary relies particularly on:

Stewart, S. M., International Copyright and Neighbouring Rights (London, Butterworths, 2nd ed. 1989); Ricketson, S., The Berne Convention for the Protection of Literary and Artistic Works: 18861986, (London, Centre for Commercial Law Studies, Queen Mary College, 1987); Cornish, W. R., Intellectual Property: Patents, Copyright, Trade Marks and Allied Rights, (London, Sweet \& Maxwell, 1989); Wittenberg, P., The Protection of Literary Property (Boston, The Writer Inc, 1986/1978, revised ed. 1978); Patterson, L. Ray, The Statute of Anne: Copyright Misconstrued, 3 Harv. J. Legis 223 (1966) and Copyright in Historical Perspective (Nashville; Vanderbilt University Press 1968); Birrel1, A., Seven Lectures on the Law and History of Copyright in Books (London, Cassell, 1899); Dock, M.-C., Etude sur le droit d'auteur, Libraire générale de droit et de jurisprudence (Paris, 1963); Pouillet, E., Traité théorique et pratique de la propriété littéraire et artistique (Paris, Marchal et Billard, 3rd ed. 1908).

Wittenberg, op. cit. at 10 .

4 Dock, Marie Claude, Genèse et évolution de la notion de propriété littéraire, LXXIX RIDA 165 (1974).

The first recorded grant appears to have been that made in 1469 by the Venetian Senate to John of Speyer, a German printer who had settled in Venice, for a period of five years. The grant actually afforded him a complete monopoly of printing in Venice. Perhaps fortunately for the Venetian printing trade he died soon after. Prager, Frank D.A., History of Intellectual Property From 1545 to 1787,26 Journal of the Patent Office Society, No. 11 (1944) at 715 (full text of grant at 750). See also, Dock, Marie Claude, Etude sur le droit d'auteur (Paris, Librairie générale de droit et de jurisprudence, 1963), at 63 .

Stewart, op. cit., para. 2.04.

Stewart, op. cit., para. 15.01, by Eugen Ulmer and Hans Hugo von Rauscher auf Weeg. For a detailed history of German Copyright see Vogel, M., Deutsche Urheber- und Verlagsrechtsgeschichte zwischen 1450 und 1850 (Frankfurt 1978).

Stewart, op. cit., para. 14.01, by Pierre Chesnais.

Privileges from the Crown were limited in time. The UK stationers' copyright, regulated by company ordinances, was deemed to exist in perpetuity.

Ricketson, op. cit., para. 1.1.

11 Venice had introduced such a rule in 1545, providing that "no printer of this city shall dare to print... any works...unless...the author or his heirs...have declared their consent and requested the printing". Quoted in Prager, Frank.D.A., supra, n. 5, at 719 and 750 .

Kaplan, Benjamin, An Unhurried View of Copyright (Colombia University Press, 1967), at 5 .

13 Berne Convention for the Protection of Literary and Artistic Works 1883, Paris Act 1971, Art. $6^{\text {bis }}$.

Wittenberg, op. cit., (2nd ed.) at 25. 
15 Stewart, op. cit., para. 2.06.

16 Kerever, André, The Achievements and Future Development of European Legal Culture, 1990 Copyright 131.

17 De Sanctis, Valerio \& de Sanctis, Vittorio in: Stewart, op. cit. at 448 . 


\section{PART II THE CONCEPT OF THE PUBLIC INTEREST IN THE HISTORY OF COPYRIGHT - NATIONAL EXAMPLES}

Chapter 4: United Kingdom

\section{The Eighteenth Century Debate on the Nature of Copyright}

The historical evolution of the copyright system in England up to and including the entry into force of the statute of Queen Anne on 10 April 1710, has been described in Chapter 2. This Statute remained in force, virtually unchanged, until superseded by the Copyright Act of $1842 .^{1}$ It was amended in $1814^{2}$ when the two contingent 14-year periods of protection were replaced by a single term of 28 years, calculated from the day of first publication, or the natural life of the author if he was still living at the expiration of that period. In the meantime, however, the Statute of Anne had given rise to an impassioned debate about the nature of copyright, often referred to as "The Question of Literary Property", ${ }^{3}$ or "The Battle of the Booksellers", which was fought out in the Courts.

In 1731, 21 years after the Statute of Anne came into force, the stationers' monopoly on printing books already in print when the Statute had come into force expired. Printers in Scotland and in the provinces issued new editions of old books and the London booksellers sought means to prevent this in a series of cases brought before both the English and Scottish courts. The booksellers argued that at common law, and regardless of the expiry of the statutory period of protection, authors had a perpetual right to authorise printing, rights which had been assigned to them. ${ }^{4}$

It was not disputed that the manuscript of a work was the property of the author and that prior to publication his right to it could exist indefinitely. The question was posed only with 
regard to published works. As Kaplan puts it: "Did the copyright in published works cease at the expiration of the limited periods specified in the statute, or was there a non-statutory, common law copyright of perpetual duration, with the statute merely furnishing accumulative special remedies during the limited periods?" 5 The argument thus raged over whether copyright was an inalienable form of property arising from the act of creation or a limited right of control or monopoly bestowed by statute in the public interest.

The debate is interesting for the purpose of this study because it opposed squarely the 'public interest' theory of copyright with that of 'natural rights'.

The issue was first decided in favour of the perpetual right by a majority of the Court of King's Bench in the case of Millar $V$ Taylor in $1769 .^{6}$ The Court held that there was a common law right of an author to his copy stemming from the act of creation and that that right was not taken away by the statute of Anne. The decision was subsequently overturned, however, by the House of Lords in Donaldson $v$ Beckett in $1774,{ }^{7}$ a case which "finally decided that the effect of the statute was to extinguish the common law copyright in published works, though leaving the common law copyright in unpublished works unaffected." ${ }^{8}$

The arguments put forward on both sides are as fresh today as in the eighteenth century.

Finding in favour of the common law right on grounds of natural law, Mr Justice Willis said:

It is certainly not agreeable to natural justice, that a stranger should reap the beneficial pecuniary produce of another man's work.... It is wise, in any state, to encourage letters, and the painful research of learned men. The easiest and most equal way of doing it, is by securing to them the property of their own works.... A writer's fame will not be the less, that he has bread, without being under the necessity of prostituting his pen to flattery or party, to get it...."

Lord Mansfield's eloquent expression of the author's natural right is famous: 
Because it is just, that an author should reap the pecuniary benefits of his own ingenuity and labour. It is just, that another should not use his name, without his consent. It is fit that he should judge when to publish, or whether he ever will publish. It is fit he should not only choose the time, but the manner of publication; how many; what volume; what print. It is fit, he should choose to whose care he will trust the accuracy and correctness of the impression; in whose honesty he will confide, not to foist in additions.... ${ }^{10}$

In Lord Mansfield's opinion, the same reasons held after publication and, therefore, it seemed to him "just and fit" to protect the copy after publication.

Mr Justice Yates, in a dissenting opinion, was against a perpetual common law copyright. For him:

all property has its proper limit, extent and bounds ... the legislature had no notion of any such things as copyrights as existing for ever at common law: ...on the contrary, they understood that authors could have no right in their copies after they had made their works public; and meant to give them a security which they supposed them not to have had before.... ${ }^{11}$

He went on to address "the inconvenient consequences the public may feel" if perpetual copyright were to be established. "Instead of tending to the advancement and the propagation of literature, I think it would stop it; or at least might be attended with great disadvantages to it."

An exclusive perpetual property in authors would be dangerous; it would give them the right to suppress as well as publish; it would lead to uncertainty and litigation if the author abandoned his copy; could lead to the fixing of such an exorbitant price upon a book as to "lock it up" "from the general bulk of mankind"; it would lead to restraints on trade. He concluded, therefore:

The legislatures have provided the proper encouragements for authors; and, at the same time, have guarded against all these mischiefs. To give that legislative encouragement a liberal construction, is my duty as a judge; and will ever be my own most willing inclination. But it is equally my duty, not only as a judge, but as a member of society, and even as a friend to the cause of learning, to support the limitations of the statute. ${ }^{12}$

The issue did not rest there. According to Birrell: "The question of literary property was discussed everywhere and by everybody."13 
In his views, Mr Justice Yates was in distinguished company. Boswell reports Dr Johnson as having been against perpetual copyright and as having the following opinion, expressed in 1773 :

\begin{abstract}
There seems (said he) to be in authors a stronger right of property than that by occupancy; a metaphysical right, a right, as it were, of creation which should from its nature be perpetual, but the consent of nations is against it; for were it to be perpetual, no book, however useful, could be universally diffused amongst mankind should the proprietor take it into his head to restrain its circulation. No book could have the advantage of being edited with notes, however necessary to its elucidation, should the proprietor perversely oppose it. For the general good of the world, therefore, whatever valuable work has once been created by an author, and issued out by him should be understood as no longer in his power, but as belonging to the public; at the same time the author is entitled to an adequate reward. This he should have by an exclusive right to his work for a considerable number of years. ${ }^{14}$
\end{abstract}

Furthermore, when the issue came for a final resolution to the House of Lords some years later in Donaldson $V$ Beckett (1774), the opinions of all the Judges were solicited by the House of Lords to assist it in reaching its decision. These opinions were not decisive but advisory. A majority ${ }^{15}$ of judges found there had been a common law copyright but that it had been taken away by the Statute of Anne so that an author was "precluded from every remedy, except on the foundation of the said statute, and on the terms and conditions prescribed thereby".

The House of Lords debated the case in the light of the opinions of the Judges and, according to the report of the case in the Parliamentary History of England, the Lords voted against the existence of common law copyright by a vote of twenty-two to eleven. ${ }^{16}$ Thus, copyright was found to be the deliberate creation of the statute of Anne and thereafter treated as statutory property. The principal opponent of common law copyright was Lord Camden, who saw in it a monopoly which would be damaging to the public at large.

Some authors are careless about profit as others are rapacious of it; and what a situation would the public be in with regard to literature, if there were no means of compelling a second impression of a useful work.... All our learning will be locked up in the hands of the Tonsons and Lintons of the age, who will set what price upon it their avarice chuses to demand, till the public become as much their slaves, as their own hackney compilers are. ${ }^{17}$ 
The fascinating aspect of these cases is the fact that they focused with such passion and eloquence on issues which are still relevant to copyright today. In Miller $v$ Taylor, the spotlight was fixed for the first time on the rights of the author. In both cases, the question of the need for a balance to be found between the rights of the author, on the one hand, and the interests of the general public, on the other, came strongly into focus. And it is the constant need to balance these two interests that has remained the principal challenge to the legislator on copyright ever since.

Between 1709 and the major copyright revision Act of 1842, the Statute of Anne was amended from time to time to add to the list of protected works. The 1709 Act protected only "books and other writings" and gradually engravings, prints, lithographs and works of sculpture were added. In 1777, musical and dramatic compositions were held to be books within the meaning of the Statute of Anne ${ }^{18}$ and in 1833 the Dramatic Copyright Act provided for a public performance right in dramatic works. ${ }^{19}$

\section{The Revision Act of 1842}

The passage of the 1842 Copyright Act ${ }^{20}$ provided the occasion for a further battle royal, this time in Parliament, on the nature of copyright; particularly controversial was the issue of the period of protection. Once again, the natural rights of the author and the public interest were at issue. The principal proponents in the debate were sergeant Talfourd, a barrister, who put forward the bill, and Lord Macaulay, the famous historian, who opposed it. The Act extended the period of copyright to the life of the author and 7 years after his death or a term of 42 years from publication, whichever should be the longer. Posthumous works were protected for 42 years from publication.

Talfourd brought all his eloquence to bear on the issue in the face of his great opponent. Arguing for extension of protection beyond the death of the author he said: 
... at the moment when his name is invested with the solemn interest of the grave - when his eccentricity or frailties excite a smile or a shrug no longer - when the last seal is set upon his earthly course, and his works assume their place among the classics of his country your law declares that his works shall become your property, and you requite him by seizing the patrimony of his children.

In making his proposal he said "he had regard to what was expedient to authors, to publishers, and to the public...." Prior to the increase in the term of protection in 1814

precisely the same arguments were then urged as against the present bill, that books would become dearer, there would be fewer written, fewer published, and fewer sold. Now, since the year 1814, books had greatly increased in number, and diminished in price, and, therefore, had he not a strong and unanswerable proof that extensions of copyright, by no means implied dearness of books.

He did not, he said, rest the "right of this bill merely on the ground of some natural right, without regard to expediency...."22

Macaulay opposed extending the period of protection beyond the life of the author, being satisfied that the measure would "inflict grievous injury on the public, without conferring any compensating advantage on men of letters." 23 He emphasised that the legislature must be free to legislate for the public good and that "no natural right of property" could survive the original proprietor. The speech contains his most famous passages about copyright, including the following:

The system of copyright has great advantages, and great disadvantages, and it is our business to ascertain what these are, and then to make an arrangement under which the advantages may be as far as possible secured, and the disadvantages as far as possible excluded....

The advantages arising from a system of copyright are obvious. It is desirable that we should have a supply of good books; we cannot have such a supply unless men of letters are liberally remunerated: and the least objectionable way of remunerating them is by means of copyright....

It is good that authors should be remunerated; and the least exceptionable way of remunerating them is by a monopoly. Yet monopoly is an evil. For the sake of the good we must submit to the evil; but the evil ought not to last a day longer than is necessary for the purpose of securing the good.

He did not think that authors would be stimulated to produce more by the knowledge that their heirs would benefit from a copyright post mortem: "Now would the knowledge, that this copyright would 
exist in 1841, have been a gratification to Johnson? Would it have stimulated his exertions? Would it have once drawn him out of his bed before noon?"

Macaulay was also of the opinion that if heirs had a copyright they would misuse it to the detriment of the public, seriously fearing, "that if such a measure as this should be adopted, many valuable works will be either totally suppressed or grievously mutilated."

As was to be expected, the debate resulted in a compromise. The principle of copyright protection continuing after the death of the author was accepted but, instead of the 60 years called for by Sergeant Talfourd, a period of only 7 years after death, or 42 years from publication, whichever should be the longer, was adopted.

Between 1842 and 1911, there were only minor legislative adjustments made: to extend protection to paintings, drawings and photographs in $1862^{24}$ and to regulate performance rights in musical works $(1882$ and 1888$) .{ }^{25}$

\section{The 1878 Royal Commission Report}

In 1875, a Royal Commission was set up to examine the laws relating to "Home, Colonial, and International Copyright", which reported in $1878 .^{26}$ It concluded that the form of the copyright law, as opposed to its substance, was badly in need of revision, it being "in many parts so ill-expressed that no-one who does not give much study to it can expect to understand it." Recommending a codification and clarification of the law, the Commission entertained "no doubt that the interest of authors and the public alike requires that some specific protection should be afforded by legislation to owners of copyright."

Of particular interest is the fact that the Commission responded to a proposal put forward for the exclusive rights of the copyright owner to be replaced by "a system of royalty": the 
first proposal for a compulsory or statutory licence. The "royalty" lobby had urged "the benefit that it is supposed would arise to the public from the early publication of cheap editions." The Commission was unconvinced and concluded "that copyright should continue to be treated as a proprietary right."

The public interest is a recurring theme in the report. A major recommendation was that the duration of copyright should in no case be calculated from the date of publication but should last for the life of the author and a fixed number of years after his death, in order "to secure that adequate encouragement and protection to authors which the interests of literature, and therefore of the public, alike demand from the state". The Commission's recommendation was to follow the example of Germany and adopt a term of life plus 30 years.

A continuing preoccupation with the need for the public to have access to cheap books is reflected in the evidence given by the Permanent Secretary to the Board of Trade, the department whose successor, the Department of Trade and Industry, is still in charge of copyright. He argued in favour of the importation into Britain without the consent of the author of colonial reprints, based on consideration of the public interest. Prices of books were allegedly very high and "altogether prohibitory to the great mass of the reading public". Colonial reprints would be cheaper and authors would not lose because they would benefit from an extended market. The Commission was not persuaded, recommending that colonial imports should be subject to the author's consent.

Important in the history of British copyright also is the strong recommendation to the Government of the day to enter into a bilateral copyright agreement with the United States of America in order to provide for reciprocal protection for British and US authors.

The recommendations of the Commission remained a dead letter. It was Britain's involvement in the preparatory work on the Berne Convention which finally gave the necessary impetus for reform. Britain was active in the conferences leading to the adoption of 
the Convention in 1886 and ratified it the following year. However, following the revision conference in Berlin in 1908, the law had to be revised if Britain was to be able to give foreign copyright owners the level of protection required by the new Berlin Act of the Convention, including protection without compliance with any formalities and a period of protection of life and 50 years thereafter.

\section{The Twentieth Century}

In 1909, therefore, a new Committee was appointed to consider and make recommendations for changes to the copyright law required by the Berlin Act. The Committee examined the Berlin Act Article by Article to see which, if any, amendments were required to the UK Act.

The report echoed the concern of the 1878 report at the confusion prevailing from the plethora of legislative provisions governing copyright, saying: "It would be a great advantage if the British law were placed on a plain and uniform basis, and that basis were one which is common so far as practicable to the nations which join in the [Berne] Convention." ${ }^{27}$

The public interest arose as an issue in relation to adopting the new term of protection recommended by the Berlin Act, namely the life of the author and 50 years after his death (hereinafter referred to as "p.m.a." (post mortem auctoris)). The committee concluded: "We do not consider that it would be prejudicial to the public interests to adopt the proposed term, and we think that it would tend to beneficial assistance in the development and progress of literature and art." ${ }^{28}$

\section{The 1911 Act}

The Copyright Act $1911^{29}$ brought about several major reforms: it abolished the requirement for registration, that leftover from the days of the Stationers' Company, altogether; it extended the term of protection to the international standard of life plus 
50 years; it provided protection for photographs and sound recordings. Works of architecture were protected as artistic works and choreographic works as dramatic works.

The adoption of 50 years p.m.a. to conform with international practice was subject to an important proviso. At any time after the expiration of 25 years from the death of the author of a published work, a compulsory licence permitted reproduction subject to payment by the publisher to the author's heirs of a $10 \%$ royalty. ${ }^{30}$ It had been argued that the interest of the public was in securing the utmost cheapening of books at the earliest possible moment. There was a similar provision under which at any time after the death of the author of a literary, dramatic or musical work which had been published or performed in public, application could be made to the Judicial Committee of the Privy Council to require the owner of the copyright to grant a licence allowing reproduction or performance of the work in public if he had refused consent. ${ }^{31}$

Films were not specifically protected but that gap was remedied by the courts in 1912 when it was held that each photograph in the film was an artistic work. ${ }^{32}$ The author was given new rights with respect to the use of his work in the making of cinematographic films and sound recordings and certain doubtful areas of the law were clarified, the author being given a dramatisation right, a translation right and a public performance right in musical works. In 1934, the courts held that the copyright in sound recordings, of which the maker or producer was the author, also included a performance right separate from that in the works recorded. ${ }^{33}$

The influence of the Berne Convention continued to make itself felt; it was revised twice in subsequent years, in 1928 at Rome and in 1948 at Brussels. Following the Brussels Revision Conference, a new Committee was appointed in 1951:

to consider and report whether any, and if so what, changes are desirable in the law relating to copyright in literary, dramatic, musical and artistic works with particular regard to technical 
developments and to the revised International Convention for the Protection of Literary and Artistic Works signed at Brussels in June 1948, and to consider and report on related matters.

The Committee in its report ${ }^{34}$ noted that the field of activity covered by its terms of reference "affects the general public to a far greater extent than would appear at first sight". It recommended that the law should be amended so as to allow accession to the Brussels Act of the Berne Convention:

We believe that it is in the interests alike of the general public and of authors, composers and artists, that the rights of the latter in the works of their brain should not merely enjoy protection in the country of origin, but also that wider protection to be gained only in association with other countries. The protection of intellectual property is not a matter which should be restricted to national boundaries. ${ }^{35}$

The perennial issue of perpetual copyright was raised, the case for it having been argued before the committee; the latter rejected the case observing: "the public at large has an overwhelming interest in the reproduction of literary, dramatic and musical works, and we are satisfied that it would be quite impossible to justify a right in perpetuity." ${ }^{36}$

The Committee further recommended the repeal of the compulsory licence provisions referred to above, stating:

For the great bulk of published works the question of a period of copyright, so far as it affects the general public, is of no importance after the first 25 years have expired. But as to the exceptional book which remains in demand at, say, the end of the first 25 years, the general public are interested in two ways. Firstly, they are concerned that authors and publishers alike should secure adequate returns for their labours, so as to ensure that these exceptional works continue to be written and published. Secondly, they are also concerned that the copyright period should not be so long that the copyright owner can indefinitely maintain prices at too high a level.

Having assessed the evidence, the Committee concluded that the compulsory licences were not "decisive to secure the publication of books in cheap editions which would not otherwise be available to the public at, or at about, the same prices". ${ }^{38}$ Moreover, no applications had ever been made to the Judicial Committee of the Privy Council for their authority to issue works of deceased authors. 
Voices were raised in protest at the Committee's recommendation and called for the Government to reject it in the name of the public interest. The compulsory licences were regarded by some as a safeguard to historians and other students requiring ready access to works of past generations.

Plant considered the safeguard to have "served as a reminder to copyright owners that there is a public interest in the exercise of the privilege which will, if necessary, be protected." 39

The Committee also proposed a number of specific amendments to the law to bring it up-to-date, and in 1956 a new Copyright Act was adopted. This Act repealed the 1911 Act and all outstanding copyright legislation.

\section{The 1956 Act}

The 1956 Act $^{40}$ duly repealed the compulsory licence provisions of Secs. 3 and 4 of the 1911 Act. It introduced for the first time specific protection for 50 years from publication to films (cinematographic works), to sound and television broadcasts and to published editions of works. The performance right in sound recordings recognised by the courts in 1934 was confirmed.

The Act also established the Performing Right Tribunal to which disputes over the terms of broadcasting and public performance licences for the use of musical works and sound recordings by broadcasters and others could be referred.

Performers were not protected by the 1956 Act. Protection under the criminal law against misappropriation of their performances was first introduced in 1925. A series of statutes -- the Performers' Protection Acts 1958-72 -- subsequently extended the protection available to them, establishing summary offences against making recordings or films of performances, performing them in public and broadcasting performances without the written consent of the performer. 


\section{The Public Interest in the Debate for Reform and the}

\section{Act}

The pace of technical development, allied to the continuing evolution of the Berne Convention, which was revised in Stockholm in 1967 and again in Paris in 1971, prompted the setting up of a new departmental Committee in 1973, under the Chairmanship of $\mathrm{Mr}$. Justice Whitford, with terms of reference, inter alia: "to consider and report whether any, and if so what, changes are desirable in the law relating to copyright as provided in particular by the Copyright Act $1956 \ldots$. $^{41}$

The Whitford Committee's report was published in $1977 .{ }^{42}$ It proposed simplification of the general structure of the Copyright Act 1956 and a whole series of reforms aimed at rationalising and updating the law, including such changes as were necessary to enable the United Kingdom to ratify the 1971 Paris Acts of the Berne and Universal Copyright Conventions.

The report was acclaimed as a highly valuable contribution to the copyright debate but legislation did not follow for over a decade. During this period, the Government legislated on an ad hoc basis to deal with such urgent matters as improved remedies against piracy and the protection of computer software and cable programmes, and produced a series of consultative documents. ${ }^{43}$ These culminated only in 1986 with a white Paper outlining the Government's legislative intentions. ${ }^{44}$ The intervening debate, described by Cornish as "a ferment of proposition and counterproposition" " ${ }^{45}$ is relevant to the subject of this study since the various reports and papers published took the public interest into account to some degree or another.

The Copyright, Designs and Patents Act $1988^{46}$ represented a major reform. It dealt not only with copyright but also revised the law relating to industrial designs, patents and trademarks. The Act has one major advantage over that of 1956; it restates the law on a more logical and consistent basis and in much clearer language and, thus, is more readily intelligible to the layman. It incorporated the previous ad hoc amendments to the 1956 Act 
which had dealt with remedies against piracy and protection with respect to computer software and cable programmes. It also introduced specific protection with respect to satellite broadcasting and cable programmes for their operators and for right owners, granted the right to control rental to the authors of films and phonograms (under UK law in both cases the producers) and computer programmes, created moral rights for authors and film directors to enable the UK to ratify the Paris Act of the Berne Convention, replaced the Performing Right Tribunal with a Copyright Tribunal with extended powers over collecting societies and provided civil rights of action for performers and producers of phonograms against unauthorised exploitation of performances.

It is instructive to examine the extent to which the Whitford Committee's report and the Government's Green and White Papers specifically addressed the issue of the public interest.

The Whitford Committee made clear its commitment to the proposition that copyright is in the public interest, within the context of the relationship between national intellectual property rights and the principle anchored in EC law of free flow of goods and services:

... There is a danger that the rights may be whittled down to an extent that makes them insufficiently rewarding to achieve their object. It is always hard for those brought up to believe in competition as the most beneficent market force, to realise that the exclusive rights which are granted by national copyright ... laws are granted because it is in the public interest to grant them. And the greater the extent to which these rights are devalued the less the benefit to the public interest. ${ }^{47}$

In relation to the problem of reprography, the Committee expressed the view "that the fact that 'education' is a good cause is not in itself a reason for depriving copyright owners of remuneration". ${ }^{48}$ Stressing the need for action to ensure remuneration for photocopying, the committee drew attention to the economic justification for copyright: 
Unless something is done there is a serious danger that, in some fields at least, publication will cease. We can envisage a vicious circle: the increase in library and other copying means smaller circulations; which means higher costs; which in its turn means more copying. In the end publication ceases.

And that, clearly, would not be in the public interest.

The Committee considered the public interest also in relation to the term of protection. It considered that "the main purpose of any copyright law must be the protection of the proper interests of the creators of works ... which are the subject of copyright." 49 It heard arguments for an increase in the term of protection of literary and artistic works and from "voices which are raised in support of a drastic reduction in term ... upon the basis that at present insufficient attention is given to the public interest in as widespread and unfettered a dissemination as possible of works of all categories." 50 It concluded that the term of protection of 50 years p.m.a in the case of literary and artistic works and from publication in the case of works produced by legal entities should remain unchanged, finding that these terms "appear to be adequate to ensure a proper return to copyright owners." The Committee also heard evidence in favour of a perpetual copyright in certain works "which, on expiry of the original term, should vest in Trustees, who would be obliged to exploit the works for the benefit of the public and to use the proceeds of exploitation for cultural purposes", that is, a public paying domain. ${ }^{51}$

The question posed by the Committee was "whether it is right in principle to establish any extended term or perpetual copyright, and more particularly any extended term or perpetual copyright with this particular aim in mind." The Committee saw the issue as a question of public interest:

Those in favour say that the public interest is best served by financing the country's cultural projects through the exploitation of the works of its dead authors. Those against say that copyright protection is only acceptable, and then only in the relatively short term, in order to resolve the conflict of public interest between a fair return to the creator and the desirability of the public having an unrestricted right of use. ${ }^{52}$ 
The Committee concluded that a perpetual copyright to provide a public paying domain was not in the public interest.

The Committee also considered the public interest with respect to exceptions, i.e. uses of copyright works which are considered as non-infringing. Newspaper interests had proposed that publication 'in the public interest' should be admitted as a defence to infringement of copyright and it called for it to be made clear, in the area of fair dealing, that extensive quotation or, indeed, in some cases, reproduction in full, could be justified on this ground. ${ }^{53}$

The Committee recommended a general exception in respect of fair dealing which, in accordance with Art. 9(2) of the Berne Convention, does not conflict with normal exploitation of the work and does not unreasonably prejudice the legitimate interests of copyright owners. It took the view that:

Any sort of work is likely to be of public interest, and the freedom to comment and criticise, to discuss and to debate, ought not, in principle, to be restricted.... There must, however, be some protection for the interests of copyright owners and ... a copyright owner is surely entitled to complain if his market is being cut into, in the sense that other people are selling the work rather than their views on the work. ${ }^{54}$

This proposal was not taken up by the Government which adopted the view that this definition could "enlarge the freedom available to users".$^{55}$

The Whitford Committee put forward two proposals which were subsequently the subject of fierce debate and ultimately rejected by the Government. These are of particular interest in the context of the public interest. The first was for a statutory blanket licensing scheme for reprography, removing photocopying from the scope of the 'fair dealing' and library exceptions. The second was for a royalty system or levy on the sale of recording machines for audio and video private copying, coupled with a supplemental blanket licensing scheme for educational recording. 
The report made the case as follows:

Complete freedom for individuals and education establishments to record for nothing from any source would not only weaken the record industry but also harm the interests of composers, writers, publishers, performers and others who are dependent on that industry, to the ultimate detriment of the whole community. ${ }^{56}$

The latter proposal was subsequently the subject of heated discussion and deliberation. The Government's view of the issue and of the public interest in relation thereto seesawed; first it called for further and convincing evidence that a levy system would provide an acceptable solution; ${ }^{57}$ subsequently, it supported the introduction of such a scheme for audio and video home taping in a Green Paper ${ }^{58}$ and put forward detailed recommendations for legislation in a White Paper in $1986 i^{59}$ finally, it dropped the matter in the Bill introduced to parliament in 1987,60 and vigorously opposed all efforts to include it during the Bill's subsequent passage through Parliament. In this debate, the Government appeared to identify the public interest only with the interest of consumers.

For example, in its 1985 Green Paper outlining Government proposals for the introduction of a levy on the sale of blank audio and video tapes, the Government proposed setting the maximum level of the levy by legislation to safeguard the public, there being "a strong public interest element entailed, with consumers likely to bear the ultimate cost." 61 The fact that, as the Government admitted "a fundamental right conferred by copyright law cannot be used in present conditions for the purpose intended by the statute, and that home taping is a major use of copyright material for which copyright owners receive no payment", appeared to weigh less in the balance. ${ }^{62}$

When in 1986, the Government set out its legislative intentions in a White Paper, it recalled that "Intellectual property is about creative ideas - ...widespread dissemination of these ideas benefits society as a whole and stimulates further creative activity." 63 In concluding that a levy on audio blank tape would be the best solution to the home recording problem, the Government stated it had taken account of the need to balance the 
interests of copyright owners and performers with those of the public at large. When the Government subsequently dropped the levy, it said it had reconsidered the balance between those interests, announcing that it had concluded that any financial benefit to copyright owners and performers would be outweighed by the adverse effects the levy would have had on consumers, especially handicapped people, concluding this time: "It is a question of balance, and on this question we have come down on the side of the consumer." ${ }^{64}$

In its 1981 Green Paper, the Government stated that: "Copyright plays a significant role in commercial life and has a considerable impact in areas such as education where there is also a public interest" and acknowledged that "consideration has to be given to its evolution in response to changing economic conditions, social requirements and technical developments." 65

In relation to the duration of copyright, the Government concurred with the recommendation of the Whitford report that the normal term of copyright should remain unchanged, recalling that: "The term of life plus 50 years is a compromise between on the one hand the economic interests of authors and their direct descendants and on the other hand the public interest in widespread and unfettered dissemination of works." 66

The Government also agreed with Whitford that perpetual copyright in unpublished works should be abolished, holding "that it is wrong for any material of possible public interest and importance to be protected by copyright in perpetuity. "67 Thus unpublished works would attract a term of life plus 50 years, as for published works.

The public interest was also addressed in the 1981 Green Paper in relation to exceptions to the right of reproduction: "The public interest demands that not every unauthorised reproduction of copyright material should constitute an infringement of copyright." ${ }^{68}$ The aim of such exceptions is "to avoid copyright acting as an impediment to the use of copyright material for certain defined purposes, while ensuring the economic interests 
of copyright owners are not thereby damaged." The Government rejected Whitford's suggestion to define fair dealing as use which "does not unreasonably prejudice the economic interests of the author" because it considered it might unjustifiably result in "further encroachment into the basic copyright."

In 1983, the Chief Scientific Adviser in the Cabinet office, who had been asked by the Prime Minister to examine whether the existing system of intellectual property was best suited to the national interest, published a report which inter alia put the case for intellectual property rights including copyright in the United Kingdom.

A system of intellectual property rights should encourage new products and processes to reach the market and bolster trade in ideas.... For a nation which produces proportionately more good ideas than most countries but has a relatively small home market and has been less successful in the application of technology, the public good lies in trading products and ideas. It is therefore in the overall national interest that a strong worldwide system of protecting intellectual property should exist. ${ }^{69}$

\section{Post 1988 - Act Developments}

Since the 1988 Act came into force, a number of statutory instruments amending the Act have been adopted to implement recent EC Directives on the subject of copyright and related rights and a further draft statutory instrument is now before Parliament. ${ }^{70}$ The 1988 Act will no doubt come to be seen as the last copyright legislation to be passed in the United Kingdom free of influence from the European Commission's programme of harmonisation of the laws on copyright and related rights. This programme was launched in 1988, with the publication of the Commission's Green Paper entitled "Copyright and the Challenge of Technology: Copyright Issues Requiring Immediate Action. "71 The Commission has the intention to legislate on a number of other issues in the future.

Implementation of the EC Directives has already had and will continue to have a considerable impact on UK copyright legislation. Since the copyright approach of the United Kingdom is in a minority within the European Union, certain concepts of 
the Continental-European author's right approach will inevitably find their way into UK law. For example, the Rental Right Directive obliges the United Kingdom to treat the principal director of a film as an author in addition to the producer, who is considered the author under the present law. Similarly, rental rights are to be granted not only to producers of films and phonograms and to authors of computer programs (as in the present UK law) but to all authors and also to performers. The Commission's future copyright programme includes a number of other areas not covered by the 1988 Act, such as home copying of sound and audiovisual materials and artists' resale rights. ${ }^{72}$

Of more immediate interest to the subject of this study is the Duration Directive, which provides for a uniform period of protection for authors of 70 years p.m.a., thus harmonising upwards to the longest period of protection in any state, that of Germany, and affecting the public interest. The rationale for this directive is discussed below in Part III. Protection for holders of so-called related rights under the directive, including film and phonogram producers, broadcasting organisations and performers is to last for 50 years. The impact of the implementation of the directive in the United Kingdom is discussed below.

\section{The Public Interest and Limitations on Copyright}

"In Britain or any other Berne Convention State, copyright arises upon the creation of a literary or artistic work and is enforceable without formalities: its potency is accordingly the greater and the need to qualify it in the public interest may be more pressing. "73

Thus, the public interest guides the legislator in determining the term for which copyright protection is accorded and the extent of the statutory exemptions or permitted acts in relation to copyright. 
As we have seen, the question of term has been central to the evolution of the debate in the United Kingdom related to maintaining the balance between the public interest in stimulating creativity by means of protecting right owners and the public interest in dissemination of and access to works protected by copyright. The case for perpetual copyright and that for a drastic reduction in the term of protection were argued, as noted above, as recently as before the Whitford Committee.

Macaulay called copyright "a tax upon the public ... [which should] not last a day longer than is necessary for the purpose of securing the good." ${ }^{74}$

As Cornish states, this 'tax' "should be broadly commensurate with the objectives of conferring copyright. The obvious economic test of this is: what measure of protection is needed to bring about the creation and production of new works and other material within the copyright sphere? ... the issue is largely a matter of the duration of copyright".$^{75}$

Duration has ever been and will surely remain a controversial matter. However, the present term of protection for authors of 50 years p.m.a. has attracted a wide consensus and follows the standard set by the Berne Convention. It is, of course, an arbitrary standard. As the Whitford Committee pointed out: "The development of copyright law in this and other countries and the acceptance of obligations under international conventions has made it virtually impossible to deal with term on a logical basis." 76

Whitford also considered whether a shorter term was justified in the case of photographs, sound recordings, cinematograph films, published editions and broadcasts. It had been suggested that there was an element of industrial activity in the creation of these works which made them less worthy of a long term of protection than literature and the arts. The Committee rejected the suggestion, pointing out that "merit, literary or artistic, 
has got nothing to do with copyright. Copyright can subsist in a work involving no creative ability". "7t concluded that the term of protection for these works - 50 years from publication should remain unchanged. Whitford finally commented, "if there are to be major changes in term it should, we think, be on the basis of international agreement." 78

As mentioned above, the duration of copyright in literary, dramatic, musical and artistic works has recently been increased to 70 years p.m.a. to comply with the EC Directive on duration. Likewise individual contributors to the making of a film benefit from 70 years p.m.a. Introducing the legislation in the House of Commons, the Minister stated that the increase was necessary because harmonisation at 50 years would have been difficult because it would have meant protection reductions in three member states, Germany (life plus 70), France (life plus 70 for musical works) and Spain (life plus 60 years). "The directive was, moreover, subject to qualified majority voting, and it became clear that most other member states were willing to accept harmonisation at life plus 70 years. In those circumstances, the UK agreed, albeit reluctantly, to accept the increased term" ${ }^{79}$ The debates in both Houses of Parliament on the matter demonstrated almost total aquiescence in what amounted in fact to a fait accompli and the public interest was scarcely mentioned. Only one peer complained that "To add twenty years to what is a generous form of law is extraordinary". ${ }^{80}$ The public interest was invoked by the Government spokesman in the Lords only in relation to the balance to be achieved between the interests of the public and those of right owners in safeguarding the interests of users affected by the revival of copyright by means of the introduction of a licence of right in consideration of reasonable remuneration. ${ }^{81}$

The increase in the term of protection has been subject to strong criticism in the United Kingdom. Laddie has described the increase as providing "an over-abundance of protection to the monopoly right owner" and posed the question: 
...what justification is there for a period of monopoly of such proportions? It surely cannot be based on the principle of encouraging artistic creativity by increasing the size of the carrot. No one is going to be more inclined to write computer programs or speeches, compose music or design buildings because 50,60 or 70 years after his death a distant relative whom he has never met might still be getting royalties. ${ }^{82}$

Another commentator, Parrinder, points out that "Dead authors already enjoy an ample period of copyright protection in this country. Will a further increase in the term of protection benefit anyone but the copyright holders? Nobody has said that it will, and the public have never been asked. ${ }^{83}$

\section{Fair Dealing}

Since the 1911 Act, certain statutory defences have been available in relation to infringement of copyright, the most important of which is fair dealing, a defence equivalent to that of 'fair use' in the USA. ${ }^{84}$ Prior to the 1911 Act, this defence had been recognised in the case law. ${ }^{85}$ According to the Government's Green Paper: "These exceptions are of obvious importance in that they seek to establish a proper balance between the legitimate interests of copyright owners and the legitimate desires of users of copyright material." 86

In the long process of deliberation leading up to the passage of the 1988 Act, there was much argument both in favour and against permitted wider exceptions. The balance of interests in the 1988 Act has not shifted substantially in one or the other direction.

The question of infringement only arises if the whole or a substantial part of a work is taken. The quality of what is copied is more important than quantity ${ }^{87}$ and, in this respect, the courts have approved the test that "what is worth copying is prima facie worth protecting." 88

The 1988 Act $^{89}$ permits fair dealing for three purposes, as did the 1956 Act: research or private study; criticism or review; reporting current events. The exception for research or private study applies only to literary, dramatic, musical and artistic works and (new in the 1988 Act) to the typographical arrangement 
of published editions. Only the production of single copies is allowed. ${ }^{90}$ It does not apply to sound recordings, films, broadcasts and cable programmes.

Whitford made a recommendation ${ }^{91}$ which the Government accepted ${ }^{92}$ to restrict the scope of the term 'research or private study' so as to exclude research carried out for the business ends of a commercial organisation. This became the subject of controversy when the Bill was introduced in Parliament. The Government was persuaded by British industrial interests to drop the restriction. They argued "that to exclude commercial research would impose additional costs on industry which would decrease its worldwide competitiveness and that any revenue raised would be swallowed up by the administrative costs of collecting it." ${ }^{93}$

Fair dealing for purposes of criticism and review is permitted in respect of all books. Multiple copies may be made provided sufficient acknowledgement is given. The same applies with respect to reporting current events except that photographs may not be copied and no acknowledgement is required if the reporting is done by means of a sound recording, film, broadcast or cable programme.

Whether a particular use has been 'fair' is for the courts to determine. Lord Denning MR stated the test to be applied, as follows :

It is impossible to define what is 'fair dealing'. It must be a question of degree. You must consider first the number and extent of the quotations and extracts. Are they altogether too many and too long to be fair? Then you must consider the use made of them. If they are used as a basis for comment, criticism or review, that may be fair dealing. If they are used to convey the same information as the author, for a rival purpose, that may be unfair. Next, you must consider the proportions. To take long extracts and attach short comments may be unfair. But, short extracts and long comments may be fair. Other considerations may come to mind also ${ }_{94}$ But after all is said and done, it must be a matter of impression. ${ }^{94}$

Other factors to be taken into account are whether the work is unpublished - an unpublished work is not automatically outside the provisions of the fair dealing defence but appropriation of 
unpublished material is a more substantial breach of copyright, if unjustified, than publication of an extract from a published work.

\section{Public Interest Defence}

The common law defence of public interest "is a defence outside and independent of statutes, is not limited to copyright cases and is based upon a general principle of common law." 95 It has, however, been given statutory recognition in the 1988 Act: "Nothing in this part affects any rule of law preventing or restricting the enforcement of copyright, on grounds of public interest or otherwise." 96 The scope of the defence remains a matter for the courts.

The courts have found that

public interest, as a defence in law, operates to override the rights of the individual, (including copyright), which would otherwise prevail and which the law is also concerned to protect. Such public interest as now recognised by the law, does not extend beyond misdeeds of a serious nature and importance to the country. ${ }^{97}$

However, as Lord Denning has stated, "The information must be such that it is a proper subject for protection", that is, not obscene, blasphemous or seriously deceptive of the public, and "there are some things which may be required to be disclosed in the public interest, in which event no confidence can be prayed in aid to keep them secret." 98

In the mid-eighties, ${ }^{99}$ the court stressed the need to differentiate between what is interesting to the public (no defence) from what it is in the public interest to be made known (defence available). The defence exists "to protect the community from destruction, damage or harm". This principle was illustrated in a 1991 case, where the court held that the defence of public interest allows the publication of secret information which, in the public interest, should be known. The fact that the information may interest the public is not sufficient. Once the information has been published, there is no further public interest requirement for further publication. ${ }^{100}$ 
An interesting example of the application of the public interest defence arose in 1988 in a case before the House of Lords. It was held that the United Kingdom courts have a general equitable jurisdiction to decline to enforce copyright claims in certain cases; two examples of such circumstances were where a work contained false statements calculated to deceive the public; and where the work was of a grossly immoral tendency. In the case in question, the publication was held to have been against the public interest and in breach of the duty of confidence which the author had owed to the crown. This being so "it was inconceivable that a United Kingdom court would afford to him or his publishers any protection in relation to any copyright which either of them may possess in the book" ${ }^{101}$

\section{Statutory Exemptions in Favour of Education and Libraries}

The 1956 Act allowed certain libraries to copy at the request of those engaged in research or private study. The development of photocopying technology "has placed on this exception a weight which it was never designed to bear". ${ }^{102}$ It was considered inappropriate, therefore, by Whitford, who proposed that a blanket licensing system should be imposed by statute, and that photocopying should be removed from the scope of the fair dealing and library exceptions. In its 1981 and 1986 Green Papers, the government rejected these proposals, concluding that voluntary blanket licensing was the appropriate solution in most cases. It recognised that, for example, music publishers believe that licensing of photocopying is not in their best interests and considered "that copyright owners should not in general be obliged to join blanket licensing schemes and should in general retain their exclusive rights." 103 It proposed a derogation from this principle, however, for education. It proposed providing legislation "to facilitate the establishment of licensing schemes for photocopying, and to ensure the right balance of interest between copyright owners and users of copyright materials." 104

The 1988 Act has made it clear that the making of multiple copies by libraries for the purposes of research and private study is not fair dealing. The Act also gives the Copyright Tribunal 
jurisdiction over general licensing schemes for reprographic copying. A number of such schemes have come into existence since the 1981 Green Paper under the aegis of the Copyright Licensing Agency (CLA), representing authors and publishers.

In the field of education, a blanket licensing scheme has been in existence between the CLA and local education authorities, representing schools, since 1986. In return for a lump sum fee, multiple copies of up to 5\% of a book published in the UK or the whole of an article in a periodical are permitted. Certain types of work are excluded, such as printed music, newspapers, maps, etc. All copying outside the terms of the licence is an infringement. A similar agreement is in force with independent schools and, since 1988, an experimental scheme is operated with certain universities. This differs from the schools scheme in that the licence fee is not a lump sum but is related to the actual number of copies made. The university scheme also preserves the fair dealing exception with respect to single copies.

The 1988 Act sets out to promote such schemes. As noted above, the Copyright Tribunal has power to arbitrate in any disputes arising therefrom but the Government has also provided a statutory licence to cover the case where no blanket licensing scheme exists. Section 36 permits photocopying by an educational establishment for the purposes of instruction of up to $1 \%$ of any work in any quarter of the year. Moreover, no blanket licence system may restrict the proportion of a work which may be copied to less than that amount, although payment may be required.

The terms of any licensing scheme for reprographic copying may be referred to the Copyright Tribunal in the case of dispute. The 1988 Act requires the Tribunal to have regard to: "(a) the extent to which published editions of the works in question are otherwise available, (b) the proportion of the work to be copied, and (c) the nature of the use to which the copies are likely to be put." 105 
The Government has also taken powers, subject to certain procedures, to extend the coverage of a licensing scheme for reprographic copying by an educational establishment for the purposes of instruction to similar works "unreasonably excluded" from the scheme, provided that such extension would not conflict with the normal exploitation of the works or unreasonably prejudice the legitimate interests of the copyright owners. ${ }^{106}$

The Act permits a number of other acts for the purpose of education including: certain things done for the purpose of instruction or examination; ${ }^{107}$ the inclusion of short passages of literary or dramatic works in anthologies for educational use ${ }^{108}$ performing, playing or sharing a work in educational activities; ${ }^{109}$ and educational recording of broadcasts and cable programmes in the absence of a licensing scheme. ${ }^{110}$

\section{Special Regulations Concerning Libraries and Archives}

There are a number of special provisions in the 1988 Act regulating copying of works by prescribed libraries and archives and the Government is given power to set out more detailed conditions in regulations, ${ }^{111}$ including the definition of prescribed libraries. Non-profit making (local authority and educational) libraries are intended and single copies may be made and supplied to people requiring them for research or private study of one article from any periodical and parts of published works, subject to payment of the cost of producing the copy and an overhead charge. There are specific restrictions prohibiting the making of multiple copies ${ }^{112}$ and rules governing, inter alia, the supply of copies to other libraries, preservation or replacement copies, etc. It should also be noted that the new right to control rental of sound recordings, films and computer programs applies to library lending whether or not a charge is made by the library. However, the Government again has powers to grant compulsory licences if the copyright owners refuse unreasonably to grant licences. ${ }^{113}$ 


\section{Other statutory Defences}

Other statutory defences to infringement include: the incidental inclusion of any work in an artistic work, sound recording, film, broadcast or cable programme; ${ }^{114}$ the use of copyright material by the public administration, e.g. in parliamentary or judicial proceedings, etc $i^{115}$ abstracts of scientific and technical articlesi ${ }^{116}$ exemptions concerning artistic works to permit photography or sketching of a publicly exhibited sculpture or building; ${ }^{117}$ playing sound recordings for purposes of non-profitmaking clubs; ${ }^{118}$ public showing or playing of broadcasts or cable programmes where no admission charge is made; ${ }^{119}$ time-shift recording of television and radio broadcasts for private and domestic use. ${ }^{120}$

\section{Conclusion}

Introducing the Copyright, Designs and Patents Bill to the House of Lords in 1988, the Secretary of State for Trade and Industry gave expression to the view of the Government of the day with respect to copyright, saying:

\footnotetext{
It has been observed that nothing can be more properly described as a man's property than the products of his mind, and over the years a system of law has been established to protect ideas - patents for inventions, copyright for literature and art, and so on. The intellectual property system has served us well by encouraging creativity and innovation and the spread of ideas.

Intellectual property is of substantial economic significance. It forms the foundations of major industries. Without copyright law, the publishing and record industries would scarcely operate. The entertainment world would be in chaos. ${ }^{121}$
}

On the question of the balance of interest between the creator and the public, he observed: "In drawing up the Bill, we have sought to provide a fair return for creative talent and those who develop and use their work, while ensuring that ideas are not locked away but are accessible to society as a whole." 122

He went on to suggest that the Bill would encourage creativity and enterprise and the growth of fair competition. 
It will be seen, therefore, that the justifications for copyright legislation in the United Kingdom have remained constant over the years. On the one hand, there is the aim to protect the natural rights of the author by protecting the products of his mind; at the same time, the copyright system aims to encourage creativity and the dissemination of ideas and knowledge to the general public. There has been a concern to balance the interest of the author in protection, on the one hand, with the interest of the public in access to works, on the other. There has been also a consistent policy on the part of successive British Governments to bring the law up-to-date regularly in order to deal with the latest technical developments. Finally, throughout the nearly 300 years of copyright law in the United Kingdom, there has been a continual concern for copyright legislation to be adapted to the public interest.

In the Government's White Paper, "Intellectual Property and Innovation", published in April 1986, the Government stressed that the protection of intellectual property benefits society as a whole and stimulates further creative activity. In order to keep intellectual property law abreast of changing conditions, it suggested that there were three aims to be achieved: first, new technical developments should be accommodated (and a review of the historical development of copyright law shows that each new major revision was prompted by such technical developments); second, the Government has to ensure that intellectual property rights strike the appropriate balance between, on the one hand, protection which ensures an adequate reward for authors and creators and, on the other hand, access to creative ideas in ways which stimulate competition and allow for the use of modern technology; thirdly, there must be an efficient system for the enforcement of intellectual property rights. The report further summed up the United Kingdom's attitude to intellectual property. saying :

The United Kingdom relies heavily on getting value from its intellectual property. To this end, it is vital that the intellectual property system should strike the right balance between protection and exploitation; it should provide protection and reward as incentives to innovation but not at the expense of stifling competition or preventing the wider use of technology. ${ }^{123}$ 
As regards copyright, it stated that the broad aims of the Government in the revision of copyright law "are to ensure continued protection for those who create copyright works, while at the same time recognising that the public has a substantial interest in the availability of their works."124

The question whether the Government pays sufficient attention to the importance of intellectual property to the economy was considered in a report published in December 1983 by the Chief Scientific Adviser to the Cabinet office. He concluded that: "While the Government devotes considerable resources to encouraging innovation generally, it does not give adequate priority to providing the system of intellectual property rights that British business requires." 125

He considered that as a nation and compared to the UK'S main trading partners, "there is insufficient awareness of the importance and value of intellectual property rights".

Following the publication of that report, the Common Law Institute of Intellectual Property (CLIP) has undertaken a series of studies into the economic value of intellectual property in order to encourage the Government to give adequate priority to the subject. Its first report on the Economic Importance of Copyright was published in $1985 .{ }^{126}$

A further study entitled "The Export Performance of the Copyright-Dependant Industries was published in 1988."127 The study showed that the copyright industries made a significant contribution to the UK balance of payments on both the visible (goods) account and in the invisible (royalties) sector. In 1988, their total export earnings represented $2.4 \%$ of total UK exports. The copyright industries were also shown to have a particularly rapid rate of growth: 127\% over the period 1982-1988 compared with 38\% for exports overall. The report concluded that the copyright industries make a very significant and increasing contribution to the UK's export earnings. 
In 1993, CLIP followed these studies up with an updated and expanded version of its 1985 study on the economic importance of copyright. ${ }^{128}$ This showed that in 1990 the copyright industries with primary direct dependence on copyright accounted for $3.6 \%$ of GDP (Gross Domestic Product), up from 2.6\% in 1982, and employed more than 800.000 people, an increase of 200.000 over 1982. Industries "substantially dependent" on copyright account for a further 1.8\%, bringing the total to $5.4 \%$ of GDP and employment of 1.3 million. The study underscores the economic value of the copyright industries and their growth potential as well as the importance of copyright to the national economy. 
Donaldson $v$ Beckett, 4 BURR. 2407. The previous year, the court of Session in Scotland had already ruled against the common law copyright in the case of Hinton $V$ Donaldson (1773) Mor 8307. Lord Kames rejected common law copyright as "contrary to law, as ruinous to the public interest, and as prohibited by statute."

\& Copinger and Skone James on Copyright, including International Copyright with the statutes and orders relating thereto and forms and precedents. Also related forms of protection (London, Sweet \& Maxwell, 13th ed. 1991), para. 1.30.

Millar v Taylor, supra note 6 , at 2334.

Ibid., at 2398 .

11 Ibid., at 2391.

See Howard B. Abrams, Historic Foundation of Copyright Law, 29 Wayne Law Review 1119 (1983); and see 17 Parl. Hist. Eng. 953 (HL 1774). Abrams argues that Donaldson $v$ Beckett has been consistently misinterpreted by the Courts in the USA and UK ever since. He points out that the usual interpretation that a common law copyright had existed but was overriden by the statute of Anne is incorrect. In fact, the House of Lords decided there had never been a common law copyright. For a further discussion of the case, see Rose, Mark, op. cit., see n. 3 above. 
17 Parl. Hist. Eng., (HL 1774), at 1000.

Bach V Longman (1777), 2 COWP 623.

Dramatic Literary Property Act 1833 (3\& 4 Will., 4, c. 15).

Copyright Act 1842 (5\&6 Vict., c. 45).

Quoted by Stewart, S. in: Two Hundred Years of English Copyright Law, 1977 Copyright 228.

Hansard, vol. 56, 1841, at $342 / 3$.

Ibid., at 344 et seq.

Fine Arts Copyright Act 1862 (25\&26 Vict., c. 68)

Copyright (Musical Compositions) Act 1882 (45\& 46 Vict., C. 40) and Copyright (Musical Compositions) Act 1888 (51 \& 52 Vict., c. 17).

Report of the Commissioners of the Copyright Commission, 1878 $[C-2036]$.

Report of the Committee on the Law of Copyright, 1909, Cmnd 4976, at 7 .

Ibid., at 16 .

Copyright Act 1911 ( 1 \& 2 Geo. 5, c. 46).

Ibid., Sec. III.

Ibid., Sec. IV.

Barker V Hutton 1912, 28 TLR 496.

Gramophone Co Ltd $v$ Stephen Cawardine \& Co, [1934] Ch. 450.

Report of the Copyright Committee, October 1952, HMSO, Cmnd 8662.

Ibid., at 3 para. 3 .

Ibid., at 7 para. 17.

Ibid., at 8 para. 20 .

Ibid., at 9 para. 23 .

Plant, Arnold, The New Commerce in Ideas and Intellectual Property (1953).

Copyright Act 1956 (4\& 5 Eliz., 2, c. 74).

There was a specific exclusion from the terms of reference of "any consideration of the merits of lending to the public as one of the acts restricted by copyright in a work." In fact, the Public Lending Right Act 1979 established a public lending right in respect of books in an entirely separate legislative process.

Report of the Committee to consider the Law on Copyright and Designs, Chairman, the Honourable Mr Justice Whitford, Cmnd 6732, HMSO, March 1977.

Reform of the Law relating to Copyright, Designs and Performers Protection, Cmnd 8302, HMSO, July 1981. Intellectual Property Rights and Innovation, Cmnd 9117, December 1983. The Recording and Rental of Audio and Video Copyright Material, Cmnd 9445, February 1985. 


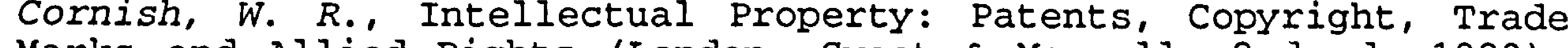
Marks and Allied Rights (London, Sweet \& Maxwell, 2nd ed. 1989), para. 9-018.

1988 Copyright, Designs and Patents Act, Chapter 48, HMSO.

Whitford Committee report, supra note 42 , para. 84 .

Ibid., para. 268.

Ibid., para. 627.

Ibid., para. 636.

Ibid., para. 643 .

Ibid., para. 646.

Ibid., para. 667.

Ibid., para. 676.

Op. cit., Cmnd 8302, supra, n. 43, Chapter 13, para. 4.

Op. cit., Whitford Committee report, Cmnd 6732, para. 320 .

Op. cit., Cmnd 8302, supra, n. 43, para 23.

The Recording and Rental of Audio and Video Copyright Material. A Consultative Document. [Green Paper] February 1985, HMSO, Cmnd 9445 .

Intellectual Property and Innovation. April 1986, HMSO, Cmnd 9712. Copyright, Designs and Patents Bill (House of Lords) 1987.

Op. cit., Cmnd 9445, Sec. VII.

Ibid., Sec. II.

op. cit., Cmnd 9712, para. 1.

Hansard, House of Lords Official Report, Vol. 489, No. 34, Thursday, 12 November 1987, at 1532 .

Op. cit., Cmnd 8302, Introduction, para. 4.

Ibid., Chapter 12, para. 5.

7 Ibid., Chapter 12, para. 8; op. cit., Cmnd 9712, Chapter 15, paras. 15.2 and 15.7 .

Op. cit., Cmnd 8302, Chapter 3, para. 1.

Intellectual Property Rights and Innovation, December 1983, HMSO, Cmind 9117, para. 1.8.

S I 1992 No. 3233 on Copyright - The Copyright (Computer Programs) Regulations 1992 (came into force 1 January 1993) implementing Council Directive 91/250 EEC of 14 May 1991 on the legal protection of computer programs; S I 1995 No. 3297 on Copyright - Rights in Performances (came into force 1 January 1996) implementing Council 
Directive No. 93/98/EEC of 29 October 1993 harmonising the term of protection of copyright and certain related rights. Two other directives, the Directive on rental right and lending right and on certain rights related to copyright in the field of intellectual property of 19 November 1992 (92/100 [1992] 0.J. L346/61) and the Directive on the coordination of certain rules concerning copyright and rights related to copyright applicable to satellite broadcasting and cable retransmission of 27 September 1993 (93/83: [1993] 0.J. L248/15) have not yet been implemented, although a draft statutory instrument for that purpose was laid before Parliament in early 1996 and is due to enter into force on 1 December 1996.

Dworkin and Taylor state that the government resisted attempts to change the term to 'fair use' because the meaning of the term was well established: Dworkin \& Taylor, Blackstones Guide to the Copyright, Designs and Patents Act, 1988 (London, Blackstone Press Limited, 1989), at 72 .

COM. (88) 172 final.

A draft proposal on home copying is expected to be put forward by the Commission to the Council before the end of 1996. A proposal for a Directive on artists' resale rights was published by the Commission on 13 March 1996 (Com (96) § 7 final).

Cornish, $W . R$., Intellectual Property: Patents, Copyright, Trade Marks and Allied Rights (London, Sweet \& Maxwell, 2nd ed. 1989), at 340, para. 13-003.

Hansard, op. cit., Vol. 56, at 348 .

Cornish, op. cit. at 259.

Op. cit., Cmnd 6732, para. 41.

Ibid., para. 633

Ibid., para. 637.

Per the Minister for Science and Technology, Ian Taylor, introducing the statutory instrument to the House of Commons, 16 December 1995, reproduced in 43 Journal, Copyright Society of the USA, No. 2, 1995, at 199 .

Lord Peston, 10c. cit. at 230.

S I 1995 no 3297, Regulation 24.

Laddie, Hugh, (The Hon. Mr. Justice Laddie), Copyright: Overstrength, Over-regulated, Over-rated?, [1996] 5 EIPR 253.

Parrinder, Patrick, The Dead Hand of European Copyright, [1993] 11 EIPR 391. See also Cornish, William R., Intellectual property, in 13 Yearbook of European Law (1994), at 485.

Bradbury V Hotten, [1872] L.R.8 Ex. 1; and see Copinger and Skone James on Copyright (London, Sweet \& Maxwell, 1980), para. 512.

Op. cit., Cmnd 8302, Chapter 13, para. 2 .

Hawkes \& Son (London) Ltd $V$ Paramount Film Service Ltd, [1934] Ch. 593. 
88

University of London Press Ltd $v$ University Tutorial Press Ltd [1916] $2 \mathrm{Ch} .601,610$; and see Copinger, op. cit., paras. 8.26 to 8.29 .

89 Op. cit., 1988 Act, s. 29 and 30.

90

Ibid., s. 29 (b) .

Op. cit., Whitford Committee report, Cmnd 6732, para. 291.

op. cit., Cmnd 8302, Chapter 2, para. 8.

Dworkin \& Taylor, op. cit. at 73.

Hubbard V Vosper, [1972] 2 WLR 394.

Beloff $V$ Pressdram, [1973] RPC 783. See also Sayal, Meena, Copyright and Freedom of the Media: A Balancing Exercise? (1995) 7 ENT.LR 263. 1988 Act, s. $171(3)$.

Per Ungoed-Thomas $\mathrm{J} .$, in Beloff $V$ Pressdram, supra n. 95.

Op. cit., Hubbard $v$ Vosper, at 395-6.

Lion Laboratories Ltd $v$ Evans, [1985] QB 526.

Newspapers v. News (UK) Ltd. [1991] F.S.R. 37.

Per Lord Jauncey in Attorney General $v$ Guardian Newspapers; same $V$ Observer; same V Times Newspapers (No. 2), [1990] A.C. 109, at 293.

Dworkin \& Taylor, op. cit. at 169.

Op. cit., Cmnd 9712, Chapter 8, para. 8.3.

Ibid., para. 8.6.

Op. cit., 1988 Act, s. 130.

Ibid., s. 137.

Ibid., s. 32 .

Ibid., s. 33 .

Ibid., s. 34 .

Ibid., s. 35 .

Ibid., s. 37-44.

Ibid., s. 40 .

Ibid., Schedule 7, ss. 6,8 and 34 .

Ibid., s. 31 .

Ibid., s. 45-50.

Ibid., s. 60 .

Ibid., s. 62-65. 
118 Ibid., s. 67.

119 Ibid., s. 72 .

120 Ibid., s. 70.

121 Supra n. 64, op. cit. at 1476 .

122 Loc. cit.

123 op. cit., Cmnd 9712 , at 3 para. 3.

124 Ibid., at 35 para. 4.

125 Op. cit., Cmnd 9117 - summary para. 3.

126 Phillips, Jennifer, The Economic Importance of Copyright (CLIP, 1985).

127 Skilbeck, Jennifer, The Export Performance of the Copyright-Dependent Industries (CLIP, 1988).

128 Price, Tristan, The Economic Importance of Copyright, Common Law Institute of Intellectual Property, (CLIP), London, 1993. Unlike the 1985 study, the 1993 one includes computer software for the first time among the industries totally dependent on copyright. 
Chapter 5: The United States of America

\section{Origins of the 1790 Act}

The British Colonies in America had no separate copyright statute. Immediately following the war of Independence $(1775-1783)^{1}$ and the establishment of the United States of America, Congress passed a resolution recommending to the several States that they secure to authors or publishers of any books not before printed the copyright of such books for a term of not less than 14 years. ${ }^{2}$ During the next two or three years, 12 of the 13 States passed Copyright Acts. ${ }^{3}$ These were variously entitled. Seven had as their object the 'encouragement' or 'promotion of literature and genius'. Four were described as having the purpose of 'securing to authors the exclusive right and benefit of publishing literary productions.'

The preambles to these early laws show that the legislators in question justified copyright under both natural law and economic principles and also had regard to the public interest. This is well illustrated by the preamble to the Connecticut statute which provided:

Whereas it is perfectly agreeable to the Principles of natural Equity and Justice, that every Author should be secured in receiving the Profits that may arise from the sale of his Works, and such Security may encourage Men of Learning and Genius to Publish their Writings; which may do Honor to their Country, and Service to Mankind.

The term of protection varied, the longest period being 21 years. While the contents of these laws were not identical, they were all clearly modelled on the Statute of Anne.

Printing in the American colonies was run on purely commercial lines.

Perhaps the most important difference between colonial America and Europe in the seventeenth and eighteenth centuries was that literature did not rely as much on patronage in America as it did in Europe and therefore American writers looked to the general public rather than wealthy or influential individuals for their financial rewards." 
Newspapers and periodicals published most of the output of American writers in serialised form.

With twelve State copyright statutes, it was not surprising that when the Constitution was drafted it should include provision for copyright. "The constitutional clause empowering Congress to enact a copyright statute reflects the belief that property rights, properly limited, will serve the general public interest in an abounding national culture." 5 The copyright clause authorises Congress to legislate: "to promote the progress of Science ... by securing for limited times to authors ... the exclusive right to their respective writings." Legislation followed rapidly. Congress passed the original Copyright Act on 31 May 1790.6 The Act was entitled: "An Act for the encouragement of learning by securing the copies of maps, charts and books, to the authors and proprietors of such copies, during the times therein mentioned." It provided for "a term of 14 years and if the author be living at the expiration of the term, an extension for a further term of 14 years, or if not, to his executors, administrators or assigns."

In the state statutes, the copyright clause of the Constitution and in the 1790 Act, the same basic ideas as to the functions of copyright were apparent as those which prevailed in England. These were that copyright is for the promotion of learning; for the benefit of the author; to prevent harmful monopoly (by imposing a limited term); and is granted by the state to provide order in the book trade.

The dominant idea in the minds of the framers of the Constitution appears to have been the promotion of learning. The proposals submitted [to the Constitutional Convention] by Madison and Pinckney, apparently arrived at independently, are instructive on this point. Both manifest an interest in having the Federal Government promote knowledge, and provide for the author's copyright in addition to other provisions for this specific purpose. The idea next in importance seems to have been protection for the author.?

As the Supreme Court said in 1954:

"The copyright law, like the patent statutes, makes reward to the owner a secondary consideration." United States $v$ Paramount Pictures, 334 US $13168 \mathrm{~S}$ Ct 915, 929, $92 \mathrm{L.Ed} \mathrm{1260.} \mathrm{However,} \mathrm{it} \mathrm{is} \mathrm{"intended}$ 
definitely to grant valuable, enforceable rights to authors, publishers, etc., without burdensome requirements; 'to afford greater encouragement to the production of literary [or artistic] works of lasting benefit to the world." "Washingtonian Pub. Co V Pearson, 306 US $30,36,59 \mathrm{~s}$. Ct. 397, 400, 83 L. ED 470.

The economic philosophy behind the clause empowering Congress to grant patents and copyrights is the conviction that encouragement of individual effort by personal gain is the best way to advance public welfare through the talents of authors and inventors in "Science and useful Arts." Sacrificial days devoted to such creative activities deserve rewards commensurate with the services rendered. ${ }^{8}$

Nimmer refers to "the philosophical issue as to whether copyright should be regarded as properly based upon the 'natural right' concept fundamental (at least in origin) to the theory of private property". In his view:

there is nothing to indicate that the Framers, in recognising copyright, intended any higher standard of creation in terms of serving the public interest than that required for other forms of personal property. We may assume that the men who wrote the Constitution regarded the system of private property per se as in the public interest. In according a property status to copyright they merely extended a recognition of this public interest into a new sector. ${ }^{9}$

The 1790 Act provided protection only to the author of maps, charts and books. Only citizens or residents of the US were protected as well as their executors, administrators or assigns. Protection was afforded against the following acts done without authorisation: printing, reprinting or publishing copyrighted works; importing copies of a protected work and selling infringing copies knowingly. Penalties included delivering up of the infringing copies to the author for destruction and a fine of 50 cents for every infringing sheet. Only half of the fine was paid to the author, the other to the US Government. The pirating of foreign works was expressly allowed and, in this, the US Statute differed from the statute of Anne. However, as regards unpublished manuscripts, the author was specifically protected against unauthorised publication.

The question whether a common law copyright in published works had existed in the US prior to the adoption of state and Federal legislation arose. As we have seen, the question whether a perpetual common law copyright existed had been settled in Great Britain in the case of Donaldson $v$ Beckett in 1774. The House of Lords had rejected the concept of a common law property in 
literary works; copyright had been established by the Statute of Anne. In 1834, the question was considered in the case of Wheaton $\checkmark$ Peters by the U.S. Supreme Court. It was decided that there had been no common law copyright in published works in the United States but that copyright had been created by the 1790 Act.

That Congress, in passing the Act of 1790 did not legislate in reference to existing rights, appears clear, from the provision that the author \& $c$. "shall have the sole right of printing," \&c. Now if this exclusive right existed at common law, and congress were about to adopt legislative provisions for its protection, would they have used this language? Could they have deemed it necessary to vest a right already vested? Such a presumption is refuted by the words above quoted, and their force is not lessened by any other part of the act. Congress, then, by this act, instead of sanctioning an existing right, as contended for, created it. ${ }^{10}$

So far as manuscripts were concerned, however, the court found: "that an author, at common law, has a property in his manuscript ... cannot be doubted; but this is a very different right from that which asserts a perpetual and exclusive property in the future publication of the work, after the author shall have published to the world... That every man is entitled to the fruits of his own labor, must be admitted; but he can enjoy them only, except by statutory provision, under the rules of property which regulate society, and which define the rights of things in general."

Legislative Developments Between 1790 and 1976

\section{$1790-1909$}

The 1790 Act was followed by a series of amending legislation extending the scope of copyright protection. Between 1789 and 1905 there were altogether 25 laws dealing with copyright. In 1802, protection was extended to prints; in 1831 musical compositions were granted protection and the term was prolonged to a first term of 28 years with a renewal term of 14 years. In 1856, the protection afforded to dramatic compositions was extended to include a public performance right. In 1865, photographs and negatives were protected. In 1870, a general revision of the copyright law took place and protection was 
extended to paintings, drawings, statues, etc. and to translations and dramatisations of existing works. In 1882 , "designs for moulded decorative articles, tiles, plaques, or articles of pottery or metal" were added. A further general revision of the law took place in 1891. That Act for the first time provided protection for non-US citizens from countries party to an international agreement to which the US belonged and which provided reciprocal protection for US works. However, the effect of this was limited by the notorious manufacturing clause which provided that foreign works were protected only if printed in the United States of America, a clause which was only repealed by the 1976 Copyright Act. The Copyright Act of 1909, which codified the law and extended the renewal period to 28 years, remained in force until 1 January 1978, when the 1976 Act took effect.

\section{The Long Road to Reform and the 1976 Act}

From 1924 until the outbreak of the 1939-45 Second World War, many efforts were made to revise the 1909 Copyright Act. A number of revision bills were introduced mainly with a view to bringing US law into conformity with the Berne Convention. "In the end, however, all these efforts bogged down in controversy among the various private interests, particularly over the fundamental differences between the Berne Convention and the US Law."11

After the war, legislative efforts aimed at US membership of the Berne Convention were abandoned and the US participated in the work leading to the adoption of the Universal Copyright Convention (UCC) in 1952. Only minor amendments to US law passed in 1954 were needed to conform with the UCC, to which the US became a party when it entered into force in 1955.

In 1955, Congress asked the Copyright office to undertake a series of studies to provide the groundwork for a general revision. "The studies were designed to present, as objectively as possible, the history and provisions of the [1909] present law, the problems it raises, past proposals for revision, comparable provisions in foreign laws and international conventions, and an analysis of the issues and alternative 
solutions."12 Using the resulting 34 studies as a basis for debate, the Register of Copyrights presented comprehensive recommendations for revision of the law to Congress in July $1961 .^{13}$ In doing so, he stated:

In arriving at our recommendations we have given consideration to all the views expressed on a particular problem.... The needs of all groups must be taken into account. But these needs must also be weighed in the light of the paramount public interest.

We have tried to find practical solutions that will afford a balance between the various private interests and at the same time safeguard the welfare of the public. ${ }^{14}$

As regards the purpose of copyright, the report concluded:

The primary purpose of copyright is to stimulate the creation and dissemination of intellectual works, thus advancing "the progress of science and useful arts". The grant of exclusive rights to authors is a means of achieving this end, and of compensating authors for their labors and their contributions to society.

Within limits, the author's interests coincide with those of the public. Where they conflict, the public interest must prevail. The ultimate task of the copyright law is to strike a fair balance between the author's right to control the dissemination of his works and the public interest in fostering their widest dissemination. ${ }^{15}$

Throughout the 1960s and 1970s, a series of bills for general revision of the 1909 Act were introduced at regular intervals in both Houses of Congress. The revision process was dogged by controversy, notably with respect to cable television, and action was delayed pending the adoption by the Federal Communications Commission of new cable television rules. Revision represented a huge task. As the House Report on the 1976 bill stated, since the 1909 Act was passed:

...significant changes in technology have affected the operation of the copyright law. Motion pictures and sound recordings had just made their appearance in 1909, and radio and television were still in the early stages of their development. During the past half century a wide range of new techniques for capturing and communicating printed matter, visual images, and recorded sounds have come into use, and the increasing use of information storage and retrieval devices, communications satellites, and laser technology promises even greater changes in the near future. The technical advances have generated new industries and new methods for the reproduction and dissemination of copyrighted works, and the business relations between authors and users have evolved new patterns. ${ }^{16}$

In 1971, however, special legislation ${ }^{17}$ was passed to create a limited copyright in sound recordings to tackle what had become 
the widespread problem of unauthorised reproduction (commonly known as piracy).

Following extensive hearings, the 1976 revision Act was finally adopted on 19 October 1976. It represented a comprehensive revision of the copyright law and was the result of more than 20 years of deliberation. It offered federal copyright protection for both published and unpublished works and specifically prohibited the application of state law to subject-matter of copyright specified in the Act. ${ }^{18}$ The Act gives protection to a broad variety of works.

The legislative history of the 1976 Act makes clear that it was intended to cover everything that had previously been subject to statutory protection, to add some new classes of copyrightable material, and to leave the door open for the courts to expand statutory coverage in step with technological advances. ${ }^{19}$

As the House Report stated:

Authors are continually finding new ways of expressing themselves, but it is impossible to foresee the forms that these new expressive methods will take. The bill does not intend either to freeze the scope of copyrightable technology or to allow unlimited expansion into areas completely outside the present congressional intent. ${ }^{20}$

Three fundamental criteria for protection are required: originality, authorship and fixation. A major reform was brought about as regards duration of protection, which, in line with international copyright norms, now lasts for 50 years from the death of the author. This reform has had consequential effects on the duration of pre-existing copyrights. Works made for hire, anonymous and pseudonymous works and sound recordings created after 1 January 1978 are protected for 75 years from the date of publication.

\section{Recent Developments}

The 1976 Act has been amended several times in the meantime. ${ }^{21}$ The most important amendment was the 1988 Berne Convention Implementation Act. This paved the way for the US adherence to the Berne Convention on 1 March 1989, "an epochal event" 22 bringing the USA into the major multilateral copyright 
Convention. Moral rights, which had never gained statutory recognition in the USA but which Member states of the Berne Convention are bound to respect, were provided for "under the confirmation of a great many common law precedents, several state statutes, and federal laws." 23 In 1990, however, Congress enacted the Visual Arts Rights Act, ${ }^{24}$ which affords limited rights of attribution and integrity to a narrowly defined class of visual artists with respect to certain artistic works and photographs. In the same year, the Computer software Amendments Act was adopted, granting authors or producers of software the right to authorise or prohibit the rental of copies, even after sale. ${ }^{25}$

The Audio Home Recording Act adopted in $1992^{26}$ deals with the problem of private copying (the non-commercial copying of recordings for personal, domestic use), combining a royalty payment system for the benefit of copyright owners with the obligation to incorporate a technical control mechanism to prevent unauthorised serial copying of copyright works in digital audio recordings and interface devices. The Act only tackles audio private copying, leaving aside the problem of video private copying. The obligation to incorporate technical controls means that any digital audio recording device or audio interface device manufactured, imported or distributed on the US market must be fitted with a device controlling copying, known as the 'serial Copy Management System'. This system does not prevent copying altogether. It allows individuals to make copies directly from original digital audio recordings; however, no further copies can then be made from those copies, thus preventing what is known as 'serial copying'. Thus the consumer's right to make copies is preserved, but the proliferation of copies which would displace sales and harm investment is avoided. ${ }^{27}$

Introducing the Act in the US House of Representatives, Congressman William $J$. Hughes said that it represented a compromise between the interests of "record companies, hardware manufacturers, and musical interests, while protecting the broader public interest." 28 
Legislation implementing the successful outcome to the Uruguay Round of the General Agreement on Tariffs and Trade (the URAA) was signed on 8 December 1994 and took effect on 1 January $1996 .^{29}$ This included changes in domestic law arising from the Agreement on Trade-Related Aspects of Intellectual Property, Including Trade in Counterfeit Goods (the TRIPs Agreement), signed on 15 April 1994. The URAA contains several significant amendments to the copyright law. It creates civil and criminal remedies to protect performers against unauthorised fixation and trafficking in sound recordings and music videos of live musical performances (bootlegging). It also provided for copyright in certain foreign works that had fallen into the public domain in the United States but not in their country of origin, being a member of the World Trade Organisation or the Berne Convention, to be restored with effect from 1 January 1996.

The Digital Performance Right in Sound Recordings Act $1995^{30}$ provides owners of copyright in sound recordings with an exclusive performance right in sound recordings that are performed by means of subscription service digital transmissions. The Act is notable for its restricted scope: it does not apply to traditional radio and TV broadcasts, or to background music services such as Muzak. Nor does it apply to music transmitted at public venues, such as restaurants, hotels and night clubs. ${ }^{31}$

Several further bills on copyright matters have been introduced in Congress since and in May 1996 an "Omnibus Copyright Bill" 32 was drafted embracing these into one piece of legislation covering the amendments proposed to adapt the Copyright Act to the digital, networked environment of the National Information Structure (NII), to extend the term of protection for copyright owners, and to expand exemptions for the payment of performance royalties with respect to broadcasting of copyright music on television and radio.

The amendments proposed by the Working Group on Intellectual Property Rights of the National Information Infrastructure Task Force and the rationale therefor are of particular interest..$^{33}$ (The proposal to extend the period of protection is discussed 
below. ${ }^{34}$ ) The role of the Working Group was to examine the intellectual property implications of the NII and make recommendations on any appropriate changes to US intellectual property law and policy. ${ }^{35}$ It is envisaged that the NII of the future will be an advanced high-speed, interactive, broadband, digital communications system connected up to a Global Information Infrastructure (GII) that will allow the world to share information, to connect, and to communicate as a global community. ${ }^{36}$ The Working Group's conclusions may be summarised as follows: the NII represents significant changes in technology that upset the balance that currently exists under the Copyright Act; its goal therefore is to accommodate and adapt the law to technological change so that the intended balance is maintained and the Constitutional purpose is served. ${ }^{37}$

Copyright protection is not an obstacle in the way of the success of the NII; it is an essential component. Effective copyright protection is a fundamental way to promote the availability of works to the public. ${ }^{38}$

... weakening copyright owners' rights in the NII is not in the public interest; nor would a dramatic increase in their rights be justified.

With no more than minor clarification and limited amendment, the Copyright Act will provide the necessary balance of protection of rights -- and limitations on those rights -- to promote the progress of science and the useful arts. Existing copyright law needs only the fine tuning that technological advances necessitate, in order to maintain the balance of the law in the face of onrushing technology. ${ }^{39}$

Congress bears a heavy responsibility in dealing with the current load of copyright legislation, all resulting from significant changes in technology which are capable of upsetting the delicate balance between competing interests and those of the public. There has been an increasing tendency in Congress to refer contentious issues "to off-the-record negotiations among interested parties" to develop a compromise they can all support. ${ }^{40}$ It is encouraging to note therefore that the chairman of the House Subcommittee on Intellectual Property and the Administration of Justice has gone on record as taking the view that Congress should be $a$ leader in the development of intellectual property policy and not merely a reactive force, encouraging parties to resolve their differences and then codifying the off-the-hill agreement. To do so: 
is an abdication of Congress's constitutional responsibility. If Congress fails to act in the face of changing circumstances, it lets others decide by default how the constitutional goal of promoting the progress of science should be achieved...Our responsibility is first and foremost to make policy: policies, which in our judgement will best further the Article 1 [of the Constitution] goal.

\section{The Underlying Philosophy in the US Law of Copyright}

The combined result of the 1790 Act and the case of wheaton $V$ Peters was to lead to a rejection of the natural rights theory as a premise for copyright protection. As Goldstein states:

The US Supreme Court expressly rejected a natural rights basis to copyright in its landmark decision wheaton $v$ Peters, where it observed that Congress, "instead of sanctioning an existing right, ... created it" when it enacted the 1790 Act. The House Report on the 1909 Copyright Act emphazized that "the enactment of copyright legislation by Congress under the terms of the Constitution is not based upon any natural right that the author has in his writings ... but upon the ground that the welfare of the public will be served and progress of science and useful arts will be promoted by securing to authors for limited periods the exclusive rights to their writings." ${ }^{42}$

Patterson describes the decision of the court in wheaton $v$ Peters in which there were dissenting judgements, as follows:

The striking point about the premises of the majority and the dissenters is that they are polar, one proceeding from the interest of the public, the other from the interest of the individual creator. This is not to say that both views did not take into account the interest of both the public and the individual author; it is to say that their premises brought the justices to different conclusions as to how best to resolve the conflict between the public's interest in learning and the author's interest in his property. The majority, viewing copyright as a monopoly, were content to protect the author's property for a limited period under the conditions prescribed by the Statute. To do otherwise would be contrary to the public interest. ${ }^{43}$

Thenceforth, the justification for copyright law in the USA was based primarily on the social benefits derived therefrom and not on reward for the author. The House Report on the 1909 Copyright

Act stated, for example:

In enacting a copyright law, Congress must consider ... two questions: First, how much will the legislation stimulate the producer and so benefit the public, and, second, how much will the monopoly granted be detrimental to the public? The granting of such exclusive rights, under the proper terms and conditions, confers a benefit upon the public that outweighs the evils of the temporary monopoly. ${ }^{4}$ 
The public interest has been, therefore, an essential factor in the development of US copyright law in the positive sense that it is regarded as a mechanism for the stimulation of creativity for the ultimate benefit of the public. "The sole interest of the United States and the primary object in conferring the monopoly lie in the general benefits derived by the public from the labours of authors." 45

The US Supreme Court has on a number of occasions interpreted the scope of the Constitutional clause and its impact on legislation enacted under it. It has frequently drawn attention to the positive aspect in which copyright serves the public interest.

The [constitutional] clause thus describes both the objective which Congress may seek and the means to achieve it. The objective is to promote the progress of science and the arts. As employed, the terms "to promote" are synonymous with the words "to stimulate", "to encourage", or "to induce". To accomplish its purpose, Congress may grant to authors the exclusive right to the fruits of their respective works. An author who possesses an unlimited copyright may preclude others from copying his creation for commercial purposes without permission. In other words, to encourage people to devote themselves to intellectual and artistic creation, Congress may guarantee to authors and inventors a reward in the form of control over the sale or commercial use of copies of their works. ${ }^{46}$

"Congress thus seeks to define the rights included in copyright so as to serve the public welfare and not necessarily so as to maximize an author's control over his or her product. "47

We have often recognized that the monopoly privileges that Congress has authorized, while intended to motivate the creative activity of authors and inventors by the provision of a special award, are limited in nature and must ultimately serve the public good. ${ }^{48}$

The monopoly privileges that Congress may authorise are neither limited nor primarily designed to provide a special private benefit. Rather, the limited grant is a means by which an important public purpose may be achieved. It is intended to motivate the creative activity of authors and inventors by the provision of a special reward, and to allow the public access to the products of their genius after the limited period of exclusive control has expired.

The limited scope of the copyright holder's statutory monopoly, like the limited copyright duration required by the constitution, reflects a balance of competing claims upon the public interest: creative work is to be encouraged and rewarded, but private motivation must ultimately serve the cause of promoting broad public availability of literature, music, and other arts. The immediate effect of our copyright law is to secure a fair return for an "author's" creative labour. But the ultimate aim is, by this incentive, to stimulate artistic creativity for the general public good. ${ }^{50}$ 
This same concern for the public interest is exhibited by Congress when considering amendments to the Copyright Act. We have seen the importance attached to the public interest by the House Report on the 1909 Act, and by the Register of Copyrights' Report of $1961 .{ }^{51}$ According to Goldstein:

The premise of social benefit imports a value judgement and an empirical judgement. Everytime Congress amends the Copyright Act it makes a value judgement about the quantity and quality of literary, musical and artistic works that are socially desirable and an empirical judgement about the amendment's probable efficiency in achieving that end. ${ }^{52}$

"But the touchstone for decision in all these cases is the same: copyright law's overarching ambition to encourage the widest possible production and dissemination of literary, musical and artistic works. Each of copyright law's principal features reveals a particular accommodation of the competing demands of incentives and access." 53

In expanding the scope of copyright protection over the years to new classes of copyright subject-matter, these principles have been applied by congress. The constitutional notions of 'writings' and 'authors' have been interpreted liberally to accommodate new classes of works deriving from new technology. As the supreme court has pointed out:

These terms [the "writings" of "authors"] have not been construed in their narrow literal sense but rather, with the reach necessary to reflect the broad scope of constitutional principles ... the congressional determination to consider specific classes of writings is dependent, not only on the character of the writing, but also on the commercial importance of the product to the national economy. As our technology has expanded the means available for creative activity and has provided economical means for reproducing manifestations of such activity, new areas of federal protection have been initiated. "54

"Sound policy, as well as history, supports our consistent deference to Congress when major technological innovations alter the market for copyrighted materials. Congress has the constitutional authority and the institutional ability to accommodate fully the varied permutations of competing interests that are inevitably implicated by such new technology. "55 


\section{The Public Interest and Limitations on Copyright}

The public interest has played a determining role, therefore, in the justification for copyright protection in the USA and in determining the subject-matter of such protection. This emphasis on taking the public interest into account may be said to have played a positive role. It also has an important impact on the duration of protection afforded and on the exceptions permitted under US copyright law by means of the application of the doctrine of fair use and pursuant to specific statutory limitations in the Copyright Act itself.

\section{Term of Protection}

The copyright clause of the Constitution empowered Congress to legislate to secure authors an exclusive right "for limited times". As Nimmer notes: "This phrase creates a very real limitation upon Congressional power ..." and "seems to represent an attempt to strike a balance between two competing interests: the interest of authors in the fruits of their labour on the one hand, and on the other, the interest of the public in ultimately claiming free access to the materials essential to the development of society."56

There could be no question in the USA of a perpetual copyright because it would be unconstitutional. Congress, nevertheless, has an unfettered discretion when it comes to fixing the term.

As we have seen, the 1790 Act originally followed the Statute of Anne on duration, providing for a term of 14 years from registration of the title prior to publication; this term was renewable by the author, if still alive, for a further 14 years. When in 1831 the original term was lengthened to 28 years, the purpose of the amendment was said to be "to enlarge the period for the enjoyment of copyright, and thereby to place authors in this country more nearly upon an equality with authors of other countries. " ${ }^{57}$ 
In 1909, the starting point of the period of protection was changed so that it was measured from the date of publication; the renewal period was also extended to 28 years, bringing the total possible term of protection to 56 years. The 1909 Act remained in force and the period of protection unchanged until 1 January 1978 although, throughout the intervening period, numerous bills were introduced to Congress which included proposals to change the period of protection.

According to a study on the duration of copyright prepared for a Congressional Committee and published in $1961,{ }^{58}$ in the various proposals put forward in these bills:

Generally speaking, the individual creators and their publishers supported a longer term and favored the life of the author plus 50 years, although they were willing to agree to a term of 60 or 56 years from creation or publication if some of their other aims could be achieved.... On the other side, favoring no extension of the term were such users as radio broadcasters and record manufacturers.

The same study considered the length of the term in the light of the limitation imposed on Congress by the copyright clause in the Constitution and stated that:

The basic consideration, therefore, is to determine what duration of limited time will best promote the progress of science and useful arts.

The term should be long enough to provide an incentive for the author, i.e., to encourage him to create by giving him the assurance that, if successful, his economic reward will be adequate.... It is not only the author who must be considered but also the members of his immediate family whom he may be obliged to support. Further, it is to the author's advantage and to the advantage of the public, to provide an adequate term of protection to make it commercially feasible for publishers and other distributors to aid him in exploiting his work. The period of protection should be sufficient to provide an adequate economic return to all of these interests, if it is true, as seems to be assumed in the Constitution, that it is to the benefit of the public to promote the creation and dissemination of intellectual works.

That statement reflects the principles of one of Professor Chafee's proposed six ideals of copyright law, ${ }^{59}$ according to which the term of protection should not exceed the purpose of protection. As the study pointed out:

The theory of the Constitution seems to be that after a period of protection sufficient to provide incentive by assuring to the successful authors and distributors an economic return adequate to 
take care of their legitimate interests, it is to the benefit of the public to have the work fall into the public domain. ${ }^{60}$

The basic term decided on in the 1976 Act, namely the life of the author plus 50 years, calculated from the "creation" of the work, brought the United States of America into line with the international standard of the Berne Convention and raises no problems with regard to the "limited times" proviso. This reform represented a major departure from the US tradition. The arguments for the change put forward by the House Committee Report in 1976 may be summarised as follows:

(1) The 56-year term under the 1909 Act was not long enough to ensure an author and his dependents the fair economic benefits from his works. Life expectancy had increased substantially.

(2) The tremendous growth in communications media has substantially lengthened the commercial life of a great many works.

(3) Too short a term harms the author without giving any substantial benefit to the public. The public frequently pays the same for works in the public domain as it does for copyrighted works, and the only result is a commercial windfall to certain users.

(4) A system based on the life of the author would provide a clearer method of computing term than a system based on "publication".

(5) The burden and expense of the renewal procedure would be removed.

(6) The perpetual, unlimited common law rights in unpublished works were to be abolished; the statutory term of 50 years p.m.a. would represent a fair recompense for that loss.

(7) The need for the USA to conform with a generally recognised world standard. ${ }^{61}$

The House Report concluded that "the advantages of a basic term of copyright enduring for the life of the author and for 50 years after the author's death outweigh any possible disadvantages." ${ }^{62}$ 
The reform also satisfied Chafee's test; for him 50 years p.m.a. had four merits. It satisfies the ideal of international protection; with the abandonment of formalities, publication ceases to be a good starting-point for the copyright period; it comes closer to the ideal of just protection - the author's life is a natural measure to which the lives of his children are related; it ceases at one and the same time for the whole of an author's life work. ${ }^{63}$

Meanwhile a proposal has been put forward to lengthen the term of copyright protection to life plus 70 years for individual authors and to 95 years for authors with legal personality. To this end the US Copyright office has held hearings and bills have been introduced in Congress. ${ }^{64}$ The proposal is a response to the adoption in the European Union of the EC Directive harmonising the term of protection of copyright and certain related rights adopted in 1993 and due to have been implemented in the member states by 1 July 1995. As discussed above, ${ }^{65}$ this increases the term of protection for individual authors to life plus 70 years and it is proposed that US law should be harmonised with the standard of the European Union to avoid US creators having 20 years less protection than their European counterparts, 20 years when Europeans would not be paying for the use of US copyright works. It is suggested that this would be unfair to authors and harmful economically to the country.

The proposal has had mixed reactions so far. International harmonization is admitted to be the primary rationale for the proposed increase in term. Opponents have argued that it would benefit corporate copyright owners rather than individual authors and the public, and would threaten access to and preservation of works that would otherwise fall into the public domain. A cogent adverse comment on the proposal from a group of professors of law at US law schools, has questioned the justification for the proposed extension and suggested that its proponents have not presented any evidence to show that the public interest in such an extended term outweighs its costs. They point out: 
We do not recognise new intellectual property rights, or strengthen old ones, simply because it appears that a worthy person may benefit; rather we do so only for a public purpose and where it appears that there will be a public benefit... the Copyright Act of 1976 is itself the product of lengthy debate and represents innumerable compromises that seek to achieve the proper balance between private returns to authors and public benefit, including a broad public domain... A natural corollary is that this delicate balance can easily be upset by a series of ad hoc changes. ${ }^{66}$

The professors also reject the idea that the United States should follow the European lead: "that should not cause us to change our underlying intellectual property philosophy, nor does it provide a reason for avoiding the careful cost/benefit analysis called for by that philosophy... The United States should be leading the world toward a coherent intellectual property policy for the digital age and not simply following what takes place in Europe." 67

\section{Fair Use}

The Supreme Court in 1985 has stated that fair use was traditionally defined as "a privilege in others than the owner of the copyright to use the copyrighted material in a reasonable manner without his consent,"68 and that the statutory formulation of the defence of fair use in the Copyright Act 1976 reflects the intent of Congress to codify the common-law doctrine. ${ }^{69}$

The earliest judicial recognition of the doctrine of fair use was given by Justice story in a decision of 1841:

The question, then, is, whether this is a justifiable use of the original materials, such as the law recognizes as no infringement of the copyright of the plaintiffs.... It is certainly not necessary, to constitute an invasion of copyright, that the whole of a work should be copied, or even a large portion of it, in form or in substance. If so much is taken, that the value of the original is sensibly diminished, or the labors of the original author are substantially to an injurious extent appropriated by another, that is sufficient, in point of law, to constitute a piracy pro tanto.... In short, we must often, in deciding questions of this sort, look to the nature and objects of the selections made, the quantity and value of the materials used, and the degree in which the use may prejudice the sale, or diminish the profits or supersede the objects, of the original work. ${ }^{70}$

For over a century, the Courts developed this theory, excusing certain otherwise infringing acts on the ground of fair use. The common-law doctrine was not codified until the Copyright Act 
1976. However, the House Report on the 1976 Act makes it clear that the intention of the legislature was not to change the doctrine as it had evolved over the years. Stating that, "the endless variety of situations and combinations of circumstances that can arise in particular cases precludes the formulation of exact rules in the statute", the report emphasises: "Section 107 is intended to restate the present judicial doctrine of fair use, not to change, narrow, or enlarge it in any way. "71 Furthermore, the statute leaves the courts freedom to consider additional factors ${ }^{72}$ and provides no guidance as to the relative weight to be given to each of the factors.

Section 107 of the 1976 Copyright Act lays down the principle that "the fair use of a copyrighted work ... for purposes such as criticism, comment, news reporting, teaching (including multiple copies for classroom use), scholarship, or research, is not an infringement of copyright". It then gives a non-exhaustive list of four factors which the courts should take into account in determining whether the use made of a work in any particular case is fair. These are:

(1) the purpose and character of the use, including whether such use is of a commercial nature or is for non-profit educational purposes;

(2) the nature of the copyrighted work;

(3) the amount and substantiality of the portion used in relation to the copyrighted work as a whole; and

(4) the effect of the use upon the potential market for or value of the copyrighted work.

A recent amendment has made it clear that the fact that a work is unpublished shall not itself bar a finding of fair use if such finding is made upon consideration of all the above factors. ${ }^{73}$

According to Ball: "The author's consent to a reasonable use of his copyrighted works had always been implied by the courts as a necessary incident of the constitutional policy of promoting the progress of science and the useful arts." 74

For Goldstein: "Section 107 and its decisional and legislative history leave no doubt that the object of the fair use defense is to confirm, not contradict, copyright law's basic goal - to 
put copyrighted works to their most beneficial use so that 'the public good fully coincides ... with the claims of individuals. "75

The fair use doctrine has also been described as having "evolved to guard against the possibility that the author's right of control over his works could defeat rather than serve the public interest in dissemination. "76

The factors enumerated in Sec. 107, were based on criteria evolved from case law. Nimmer cites the following as a typical example of factors taken account of by the courts:

Fair use is to be determined by a consideration of all of the evidence, and among other elements entering into the determination of the issue, are the extent and relative value of copyrighted material, and the effect upon the distribution of objects of the original work. Whether a particular use of a copyrighted article, without permission of the owner, is a fair use, depends upon the circumstances of the particular case, and the court must look to the nature and objects of the selections made, the quantity and value of material used, and the degree in which the use may prejudice the sale, diminish the profits, or supersede the objects of the original work ... fair use is to be determined by a consideration of all the evidence in the case....77

Goldstein states that Congress and the courts have reconciled the public good with the claims of individuals through two, overlapping, approaches to the fair use doctrine. These approaches he describes as a private benefit approach and a public benefit approach. The former excuses uses that the copyright owner would have licensed but for insurmountable transaction costs. The latter excuses the use, even in the absence of transaction costs, "if the social benefit of the use outweighs the loss to the copyright owner." The private benefit approach to fair use allows use that would have been made under licence if transaction costs (costs of user in searching out and negotiating a licence with the copyright owner) had not precluded licence negotiations; in other words where there has been market failure. This approach requires also that the benefits conferred by the use will exceed the losses its use will inflict on the copyright owner.

"The public benefit approach to fair use will excuse users, even in the absence of transaction costs, if the social benefit of the 
use outweighs the loss to the copyright owner." ${ }^{78}$ However, as the Supreme Court noted in Harper $v$ Row: "It is fundamentally at odds with the scheme of copyright to accord lesser rights in those works that are of greatest importance to the public. Such a notion ignores the major premise of copyright and injures author and public alike."79 For the public benefit approach to allow fair use an overriding public need must be conclusively demonstrated. ${ }^{80}$ But

where a claim of fair use is made, a balance must sometimes be struck between the benefit the public will derive if the use is permitted and the personal gain the copyright owner will receive if the use is denied. The less the adverse effect that an alleged infringing use has on the copyright owner's expectation of gain, the less public benefit needs to be shown to justify the use. ${ }^{81}$

\section{Statutory Exceptions to Protection}

The public interest also dictates the decisions of Congress with regard to the express limitations imposed in the Copyright Act itself on the exercise of the exclusive rights granted to right owners. Section 106 of the Copyright Act grants copyright owners the exclusive right to do and to authorise five uses of their works, subject to the general limitation for fair use (Sec. 107), already discussed, and subject also to certain specific limitations.

The five exclusive rights granted are the rights to reproduce; to prepare derivative works; to distribute copies to the public; to perform the work publicly and to display the work publicly. "The five fundamental rights that the bill gives to copyright owners - the exclusive rights of reproduction, adaptation, publication, performance, and display - are stated generally in Section 106. These exclusive rights, which comprise the so-called 'bundle of rights' that is a copyright, are cumulative and may overlap in some cases." 82

These five rights are expressed in broad language and together cover nearly all economically important uses of copyright works. However, limitations are imposed on these all-encompassing rights in subsequent sections which narrow the scope of the rights to 
meet what are considered to be the needs of the general public. The limitations include exemptions (e.g. certain reproductions by libraries for archives and for non-profit and charitable uses), compulsory licences (e.g. in connection with public broadcasting activities) and the defence of fair use.

The principle that guided Congress in deciding whether to leave a particular exclusive right intact or to subject it to an exemption, compulsory license or defense is the long-standing precept that rights should be so adjusted that the public good fully coincides ... with the claims of individuals.... Either or both of two judgements, one economic, the other political, underlie Congress' decision in any case to subject an exclusive right to an exception, compulsory license or defense. ${ }^{83}$

Goldstein gives various examples of how these principles have been applied in the law. He suggests that the exemption for performance or display of a work by instructors or pupils in the course of face-to-face teaching activities (Sec. 110(1))

reflects the economic judgement that search and negotiation costs will systematically prevent classroom teachers from obtaining licenses to perform copyrighted works in classroom settings.... The exemption for classroom performances also reflects a political judgement that educational uses are more socially productive than certain other uses of copyrighted works and thus should enjoy added weight in the copyright balance between private claims and the public good.

Similar considerations prompted Congress in establishing the compulsory licence system in favour of cable operators. As is stated in the House Report:

In general, the Committee believes that cable systems are commercial enterprises whose basic retransmission operations are based on the carriage of copyrighted program material and that copyright royalties should be paid by cable operators to the creators of such programs. The Committee recognizes, however, that it would be impractical and unduly burdensome to require every cable system to negotiate with every copyright owner whose work was retransmitted by a cable system. Accordingly, the Committee has determined to maintain the basic principle of the Senate bill to establish a compulsory copyright license for the retransmission of those over-the-air broadcast signals that a cable system is authorized to carry pursuant to the rules and regulations of the FCC. ${ }^{85}$

An important limitation on the rights of copyright owners is provided for in Sec. 108 with respect to reproduction by libraries and archives. In this provision, Congress sought to establish a balance between the interests of right owners and users by allowing libraries and archives or their employees to 
reproduce or distribute no more than one copy of a protected work, under certain conditions. To ensure that this balance has been fairly struck and will continue to be so, Congress directed the Register of Copyrights to submit to Congress, at five-year intervals, "a report setting forth the extent to which this section has achieved the intended statutory balancing of the rights of creators and the needs of users." 86

\section{Conclusion}

As we have seen, in the United States of America the underlying purpose and philosophy of copyright legislation is to foster the growth of learning and culture for the public welfare. The grant of exclusive rights to authors for a limited time is seen to be a means to that end. These principles were stated cogently in the House Report on the Copyright Act of $1909:^{87}$

The enactment of copyright legislation by Congress under the terms of the Constitution is not based upon any natural right that the author has in his writings, for the supreme court has held that such rights as he has are purely statutory rights, but upon the ground that the welfare of the public will be served and progress of science and useful arts will be promoted by securing to authors for limited periods the exclusive rights to their writings. The Constitution does not establish copyrights, but provides that Congress shall have the power to grant such rights if it thinks best. Not primarily for the benefit of the author, but primarily for the benefit of the public, such rights are given. Not that any particular class of citizens, however worthy, may benefit, but because the policy is believed to be for the benefit of the great body of people, in that it will stimulate writing and invention to give some bonus to authors and inventors.

Protection for authors and other right owners is therefore granted because it is deemed to be in the public interest to stimulate creativity and to ensure the widest possible dissemination of works. Similar considerations determine the extent of limitations on authors' rights. The principles governing the establishment of such limitations were described in the Register's report on the general revision of the US Copyright Law of July 1961.

Within reasonable limits, the interests of authors coincide with those of the public. Both will usually benefit from the widest possible dissemination of the author's works. But it is often cumbersome for would-be users to seek out the copyright owner and get his permission. 
There are many situations in which copyright restrictions would inhibit dissemination, with little or no benefit to the author. And the interests of authors must yield to the public welfare where they conflict.

While some limitations and conditions on copyright are essential in the public interest, they should not be so burdensome and strict as to deprive authors of their just reward. Authors wishing copyright protection should be able to secure it readily and simply. And their rights should be broad enough to give them a fair share of the revenue to be derived from the market for their works. ${ }^{88}$

In recent years, there has been an increasing recognition on the part of the US Government of the economic and cultural importance of copyright. As regards its cultural impact, the Register in a supplementary report published in 1965 emphasised:

The inter-relation between copyright and the communications revolution is fully as important to our age as the inter-relation between copyright and the revolution brought on by the printing press was to an earlier one. Somehow people must be made to realise that the copyright statute of a country not only shapes its cultural and intellectual development, but actually penetrates into the lives and thinking of every citizen. ${ }^{89}$

As regards the economic significance of copyright, in 1983, the Copyright office was requested by the chairman of the Subcommittee on Patents, Copyrights and Trade Marks of the Senate Committee on the Judiciary, to prepare biennial reports concerning the economic scope of the copyright industries and their impact on the US economy. The first of these reports was published in $1984 . .^{90}$

The major findings of the 1984 report, which was based on 1977 statistics, was that the copyright industries in the United States of America contributed some US\$55 billion to the US economy, which amounted to approximately $2.8 \%$ of the Gross National product. It also showed that the copyright industries employed 2.2 million people, that is, approximately $2.2 \%$ at the time of the civilian labour force of the United States of America. Due to budget cuts, no subsequent reports were issued by the Copyright office.

Since then surveys on the economic contribution of the copyright industries to the US economy have been published at regular intervals in 1990, 1992, 1993 and 1995 by the International Intellectual Property Alliance. ${ }^{91}$ The 1990 report showed that the 
US copyright industries had achieved dramatic growth in the intervening years since the 1984 report and concluded that "the continued health of these industries had become critical to the longterm prospects of the US economy".

According to the latest report published in January 1995, the copyright industries have continued to grow more rapidly than the remainder of the economy. From 1977 to 1993, the core US copyright industries ${ }^{92}$ share of US GDP (Gross Domestic Product) rose from $2.2 \%$ to $3.7 \%$, employing more than 2.9 million people or $2.5 \%$ of the US work force. Over the period 1991-1993, these core copyright industries had experienced an annual growth of $5.6 \%$ per year whereas, during the same period, the remaining sectors of the US economy had grown at only $2.6 \%$ annually. The report also drew attention to the fact that the copyright industries of the United States had large foreign markets, estimating that in 1993 the core US copyright industries generated revenues from foreign sales of over US\$45.8 billion (thousand million).

Copyright in the United States of America has become, therefore, an increasingly important issue in national policy debates. It is also playing a prominent role in US diplomatic and trade policy. Obtaining improved protection for intellectual property, including copyright, abroad has become a major objective of the US administration's efforts in its bilateral relations with other countries. This was demonstrated, in particular, in the Uruguay Round negotiations of the General Agreement on Tariffs and Trade (GATT), which inter alia resulted in the adoption of the Agreement on Trade-Related Aspects of Intellectual Property Rights, Including Trade in Counterfeit Goods (the TRIPs Agreement), signed on 15 April 1994.

In 1988, the then US trade representative, Mr Clayton Yeutter, remarked:

No country benefits from the theft of another's intellectual property. The United States is not the only country with inventors. We want to encourage innovative people everywhere to bring their creativity to the international market place. If countries throughout the world were to provide incentives to foster technological invention and 
innovation, rather than to steal it, we would all be vastly better off. We cannot build a sound international trading system on a foundation of piracy. ${ }^{93}$

The constancy of the copyright policy of the United States of America was recently illustrated in the september 1995 Report of the Working Group on Intellectual Property Rights "Intellectual Property and the National Information Infrastructure" already referred to, as follows:

The copyright law should also serve the public interest -- and it does. While, at first, blush, it may appear to be in the public interest to reduce the protection granted works and to allow unfettered use by the public, such an analysis is incomplete. Protection of works of authorship provides the stimulus for creativity, thus leading to the availability of works of literature, culture, art and entertainment that the public desires and that form the backbone of our economy and political discourse. If these works are not protected, then the marketplace will not support their creation and dissemination, and the public will not receive the benefit of their existence, or be able to have unrestricted use of the ideas and information they convey. ${ }^{94}$ 
The independence of the new nation was recognised by Great Britain in the Treaty of Paris (1783).

2 Resolution of 2 May 1783 on the reports of Mr Williamson, Mr Izard and Mr Madison, see Wittenberg, Philip, The Protection of Literary Property (Boston, The Writers Inc Publishers, rev. ed. 1978), at 32 .

3 Wittenberg, op. Cit., at 33.

Connecticut, 1783, January session: An act for the encouragement of literature and genius;

Massachusetts, 17 March 1783: An act for the purpose of securing to authors the exclusive right and benefit of publishing their literary productions for twenty-one years;

Maryland, 21 April 1783: An act respecting literary property;

New Jersey, 27 May 1783: An act for the promotion and encouragement of literature;

New Hampshire, 7 November 1783: An act for the encouragement of literature and genius, and for securing to authors the exclusive right and benefit of publishing their literary productions for twenty Years;

Rhode Island, 1783, December session: An act for the purpose of securing to authors the exclusive right and benefit of publishing their literary productions for twenty-one years;

Pennsylvania, 15 March 1784: An act for the encouragement and promotion of learning by vesting a right to the copies of printed books in the authors or purchasers of such copies during the time therein mentioned;

South Carolina, 26 March 1784: An act for the encouragement of arts and sciences;

Virginia, October 1785: An act for securing to the authors of literary works an exclusive property therein for a limited time;

North Carolina, 19 November 1785: An act for securing literary property;

Georgla, 3 February 1786: An act for the encouragement of literature and genius;

New York, 29 April 1786: An act to promote literature.

4 Stewart, S. M., International Copyright and Neighbouring Rights (London, Butterworths, 2nd ed. 1989), para. 2.17.

Madison James, see Introduction, supra n. 9.

6 Laws of the First Congress, Second Session, Chapter XV (see p. 241 of this study).

7 Patterson, L. R., Copyright in Historical Perspective (Nashville, Vanderbilt University Press, 1968), at 193.

8 Mazer V Stein, 347 US 201, 74 S. Ct. 460.

9 Nimmer, Melville B., Nimmer on Copyright. A Treatise on the Law of Literary, Musical and Artistic Property and the Protection of Ideas, Vol. I (Matthew Bender, 1990 ed.), para. 1.03A.

1033 US ( 8 Peters) 591.

11 Report of the Register of Copyrights on the General Revision of the US Copyright Law, 87th Congress, 1st session, July 1961, at $\mathrm{x}$.

LoC. cit.

13 Register's Report, op. cit., supra n. 11. 

$S$ 483); music licensing bills (HR 789, S 1137, S 1619 and $S$ 1628); these bills all died with the adjournment of the $104^{\text {th }}$ Congress in October 1996 but are likely to be reintroduced in the future. The Omnibus Bill was never in fact actually introduced to Congress. 
Report of the Working Group on Intellectual Property Rights (NII Report), Bruce A. Lehman, Assistant Secretary of Commerce and Commissioner of Patents and Trademarks, Chair, Washington, September 1995.

See infra p. 78 .

NII Report, op. cit. at 2 .

Ibid. at 8 .

Ibid. at 212 .

Ibid. at 16 .

Ibid. at 17 .

See supra nn. 28 and 31. This occurred with respect to the music licensing bill S 1628, since overtaken by the Omnibus Copyright Bill, which when introduced in the senate "was offered as a compromise measure, worked out through hours of negotiations with the interested parties". See BNA's Patent, Trademark \& Copyright Journal, Vol. 51, No. 1271 of 28 March 1996. The same happened over the adoption of the fair use bill H R 4263 in 1992 (P.L.102-492, 106 stat. 3145, 102d. Cong. 2d. sess. (1992). See comment by Litman, Jessica, in Copyright and Information Policy, 55 Law and Contemporary Problems, (1992) 185 at 196. See also Olson, Thomas $P_{\text {., }}$ The Iron Law of Consensus: Congressional Responses to Proposed Copyright Reforms since the 1909 Act, 36 Journal, Copyright Soc. of the USA, 109 (1989).

Speech of Rep. William Hughes (D-NJ) to Copyright Society of the USA, 7 October 1993.

Goldstein, Paul: Copyright Principles, Law and Practice, 3 Vols. (Boston, Little, Brown \& Co. 1989), para. 1.1.

43 Patterson, L.R.: Copyright in Historical Perspective (Nashville, Vanderbilt University Press 1968) p. 211.

44 House of Representatives Report No. 2222, 60th Congress, 2nd session, (1909) p. 7.

45 Film Fox Corp v Doyal, 286 US 123,127 [1932].

46 Goldstein $v$ California, 412 US 546, 37.

47 Harper \& Row Publishers Inc $v$ Nation Enterprises, 225 US PQ 1089.

48 Fogerty V. Fantasy, Inc., 114 S. Ct. 1023 [1994].

49 Sony Corp of America V Universal City Studios, 220 US PQ 673.

Twentieth Century Music Corp $v$ Aiken, 186 US PQ 67.

51 See supra nn. 11 and 44.

52 Goldstein, op. cit., para. 1.1.

53 Ibid., para. 1.2.1.

54 Goldstein $v$ California, supra note 46 , at 177. 

Analysis of the Betamax Case and its Predecessors, 82 Colum. L. Rev. 1600 (1982).

77 Nimmer, op. cit. at 13-102.9, citing Mathews Conveyor Co. v PalmerBee Co., 135 F 2d 73, 85 (6th Cir. 1943).

Sony Corp of America v Universal City Studios, 220 US PQ 675.

Nimmer, op. cit., para. 1.05.

Report of the Committee on the Judiciary of the House of Representatives, 7 Register of Debates, Appendix CXIX.

Study 30 - Duration of Copyright, prepared for the Subcommittee on Patents, Trade Marks and Copyrights of the committee on the Judiciary, US Senate, Eighty-Sixth Congress, Second Edition, Washington 1961.

Chafee, z. Jr., Reflexions [sic] on the Law of Copyright, I \& II, 45 Columbia Law Rev. 503 (1945).

Supra n. 58, op. cit. at 80 .

Supra n. 16, op. cit. at 134.

Ibid. at 136 .

Chafee, op. cit. at 731.

See supra n. 32 .

See supra, pp. 43 and 45 .

Karjala, Dennis S. et al., Comment of US Copyright Law Professors on the Copyright office Term of Protection Study, [1994] 12 EIPR 531.

Ibid. at 532 .

Ba11, H., The Law of Copyright and Literary Property (1944), at 260. Harper $v$ Row, supra n. 47, at 1076 .

Folsom v Marsh, 9F Cas. 342, at 348.

House of Representatives Report No. 94, at 66.

$D C$ Comics Inc $v$ Unlimited Monkey Business Inc, 598 F Supp. 110 (N D Ga 1984).

P.L. 102-492, 106 Stat. 3145, 102d. Cong. 2d. Sess. (1992).

Ba11, H., supra n. 68, 10c. cit.

Goldstein, op. cit., para. 10.1.

Goldstein, op. cit., para. 10.1.2.

Harper $v$ Row, supra note 47 , at 1080. 
80 Supplementary Report of the Register of Copyright on the General Revision of the US Copyright Law, 89th Congress, 1st session, May 1965, at 27-28.

81 MCA InC $V$ Wilson, $677 \mathrm{~F} 2 \mathrm{~d} 180,211$ US PQ 577.

82 Supra n. 16, op. cit. at 61.

83 Goldstein, op. cit. at 515.

84 Goldstein, op. cit. at 516 .

85 House Report, supra n. 71, op. cit. at 90.

86 Copyright Act 1976, Title 17 US Code, Sec. 108 (i).

87 Supra. n. 44 , op. cit. at 7.

88 Register's Report, op. cit., supra n. 11, at 6.

89 Supplementary Report of the Register of Copyrights on the General Revision of the US Copyright Law, 89th Congress, 1st session, May 1965, at XIV.

90 Report of the US Copyright office to the Subcommittee on Patents, Copyright and Trademarks of the Committee on the Judiciary, US Senate, on the size of the Copyright Industries in the United States, December 1984 .

91 Siwek, Stephen \& Furchtgott-Roth, Harold, Copyright Industries in the US Economy, Reports prepared for the International Intellectual Property Alliance (IIPA), November 1990, September 1992, October 1993 and January 1995.

92 Defined as industries that primarily create copyright works or produce copyright-protected materials.

Press Release, Office of the US Trade Representative, 26 February 1988.

94 NII Report, op. cit., n. 33 supra, at 16. 


\section{Chapter 6: France*}

\section{Origins of the Law}

In France, as elsewhere in Europe, the history of copyright, or to be more precise of authors' rights, has its origins in the development of the printing trade. The first printing press began operating in Paris in 1470 and, by 1510, there were more than fifty in use. ${ }^{1}$ The grant of the first privileges to printers took place in 1507 and 1508. Their aim, according to Pouillet, was, "by the grant of a monopoly to the publisher, to protect him against the disastrous competition which other printers could have subjected him to by profiting from his work and thereby to enable him to recover the costs invested by him in the operation" . ${ }^{2}$

The first privileges were granted with respect to religious texts, such as, for example, the epistles of St. Paul. Even before the age of printing, new books could not be published without permission of the Theology Faculty of the University of Paris, and such permission continued to be required before a new book could be printed. This was a mere licence to print, which conferred no exclusivity on the holder, but certified that there was nothing in the book contrary to the faith or state security. This system of censorship was confirmed by an edict of François I in $1521^{3}$ and in 1537 the requirement to obtain permission to print any book was again confirmed at the same time as an obligation on the printer to deposit one copy thereof in the King's Library at Blois was introduced. ${ }^{4}$ Originally, permission to print was separate from the privilege and had to be obtained before a request for a privilege was made. In time, permission to print and a request for a privilege were sought and granted simultaneously from the crown. The privilege did not recognise authors' rights and was not intended to reward the creation of the work. By granting the beneficiary the exclusive right to print and sell the work in question, the privilege was intended to enable the publisher to recoup his printing costs and obtain some reward for his commercial risk. 
In the early days, privileges were not granted to authors themselves. ${ }^{5}$ Privileges served the crown as a means of encouraging the publication of such works as it considered to be in its interest. To facilitate censorship control, privileges were only granted on condition the book would be published by a Parisian bookseller. This led in due course to protests from booksellers in the provinces but throughout the sixteenth century enabled the monarchy to keep strict control of the book trade. Penalties for failure to obey the law were draconian. An order of 1566 forbade the printing of any book without permission on pain of being hanged or strangled. 6

Privileges were originally temporary and granted for a certain number of years. Like in England, however, the printers sought perpetual privileges on the ground that short-term privileges did not enable them to recover their costs. The Parliament opposed perpetual privileges since the monopolies they represented, by eliminating all competition, meant that the price of books was too high. Thus, in a series of Decrees adopted by Parliament between 1551 and 1586, and subsequently confirmed by letters patent of the king in 1618, the following principles were established:

- privileges could only be granted in respect of new works;

- they could not be renewed unless the existing work had had new material added to it.

Thus, at the start of the seventeenth century, privileges for old works were no longer available and such works had entered the public domain. It was considered that prolongation of privileges was damaging to freedom and industry and that privileges for new works would encourage creativity ${ }^{7}$. This was not the end of the story, however. In 1649, in response to the demands of the booksellers, the crown reintroduced both privileges and prolongations for old books. The booksellers had successfully argued that the fact that these were no longer available caused great harm to the public, because without them it was uneconomic to publish such books. However, Parliament refused to ratify the royal edict. This confused and unsatisfactory situation continued 
throughout the seventeenth and well into the eighteenth centuries, but the crown held the upper hand. Privileges continued to be granted only to Parisian booksellers and renewals continued to be granted for "new" books, although from 1671 on renewals were not granted for "old" books, defined as having been written by authors dead before 1470. These were considered to have fallen into the public domain.

Throughout this period, authors, as such, remained unprotected by the law. Their rights did not remain totally unrecognised, however, and from an early stage privileges were sometimes granted to authors themselves. Dock gives a number of examples, including those granted by François I and Henry II to Rabelais and by Charles IX to Ronsard. ${ }^{8}$ However, the author had no right to print or sell his work and was therefore obliged to cede exploitation to a bookseller and, as a matter of practice, manuscripts of books were sold outright. Nevertheless, the special nature of the connection between the author and his work was not wholly overlooked. As early as 1586, in a dispute over the grant of a privilege, Marion stated: "The author of a book is fully the master thereof, and as such may freely dispose thereof.... The reason for this is that men, by common instinct, recognise one towards the other that each individual is lord of what he makes, invents and composes". ${ }^{9}$

The authors themselves did not claim rights. Dock suggests that this was because they felt it to be beneath their dignity to concern themselves with material matters and because financially they were supported by the booksellers, by payments in return for dedicating books to patrons, and by pensions received from patrons.

As in England, it was the booksellers who first invoked the rights of the authors in a dispute which pitted the booksellers of Paris against those of the provinces, who argued that prolongations of privileges were contrary to the public interest. ${ }^{10}$ In 1725, Louis d'Héricourt, the advocate who defended the monopoly of the paris booksellers, based his case on the following arguments: the author creates, and his creation is his 
own; it is his property; his right is independent of the privilege accorded to the bookseller; he is the absolute master thereof and, therefore, he is free to dispose of it to whom he pleases. The booksellers of Paris hold their rights, not from the King and his privileges, but from the authors and the agreements concluded with them; they may not, therefore, have their rights taken away. He went so far as to say: "Thus, the king has no right thereto, so long as the author is alive or represented by his heirs or beneficiaries; he may not transfer it to anyone by means of a privilege without the permission of he to whom the work belongs" [i.e. the bookseller]. ${ }^{11}$

D'Héricourt suggested that the property right of the author was a perpetual right. Conceding that works "must be communicated to the public in the public interest", this meant that the authors should be in a position to sell or transfer their works to others in order to bring such communication about. Thus, a bookseller who had obtained a privilege to print the work should remain the owner of the text in perpetuity, and be able to pass it on to his descendants like a piece of land or a house. ${ }^{12}$

As Pouillet pointed out, the principle of the property right of authors, first invoked by the booksellers in their own interest, was a double-edged sword, which inevitably came to be turned against them. ${ }^{13}$ Thus, in the course of time, the authors and, in particular, their heirs claimed the prolongation of expired privileges for themselves, arguing that privileges could not be renewed in favour of booksellers without the consent of the author or his heirs. In 1761, the grand-daughters of la Fontaine obtained a new privilege, on the expiration of that of the original publisher, which was granted to them by the King's Council on the ground that "the works of their grandfather belonged to them by right of heredity". ${ }^{14}$ Recognition that authors had certain rights dates from this time, although such rights as they had were by common consent transferred to the bookseller contracted to print and publish the work. ${ }^{15}$ It was not until 1777 that the rights of the author were formally recognised within the system of privileges. 
Provincial booksellers continued to petition the crown in opposition to the de facto monopoly over the new-book market of the Parisian booksellers. In support of their case, they invoked the public interest. A petition addressed to the King by the booksellers and printers of Lyon is typical of their claims:

What is a privilege? It is a prerogative or advantage accorded by the Sovereign to a person who benefits therefrom to the exclusion of all others, contrary to the common law.... Once an inventor or author has been compensated for his costs and expenses, his arrangements and his efforts, whether financially or as regards his reputation, everybody should have the right to enjoy the gift of his work. Society owes gratitude and recompense, but both have their limit and measure. If this were not so, every invention would represent a tax on each individual, which would hinder industry and would necessarily destroy competition and trade. ${ }^{16}$

On 30 August 1777, six regulations were promulgated by the King's Council concerning the printing and book trade, of which two are relevant, those concerning privileges and counterfeiting. ${ }^{17}$

The Regulation on Privileges, as amended in 1778, provided that a bookseller who had obtained a privilege would enjoy its benefit for the specific duration granted or for the life of the author, if the latter survived the term of the privilege. After the expiration of a privilege, or the death of the author, the holder of the privilege could obtain a licence to reprint the work but without prejudice to the right of third parties also to obtain a licence to print the same work. An author who obtained a privilege in his own name had the right to print and sell his own work himself and in such case could benefit from the privilege for himself and his heirs in perpetuity. However, if he sold the right to exploit his book to a bookseller he lost all rights in the work and the duration of the privilege was reduced to the life of the author.

The King's Council defined the nature of a privilege from the Crown as follows:

His Majesty has recognised that a privilege for a text is a grace founded in Justice... The perfection of the work requires that the publisher be allowed to enjoy this exclusive claim during the lifetime of the author...but to grant a longer term than this, would be to convert the enjoyment of a grace into a property right. ${ }^{18}$ 
Dock described the effect of these regulations as follows: "[The privileges] of publishers were real, temporary monopolies, granted in the interest of the general public and which sacrificed freedom to publish works for a period in order to encourage publishers with the incentive of short-term exclusivity" ${ }^{19}$

The Regulation on Counterfeiting prohibited the reproduction of books for which privileges had been given and the printing of such books without permission after expiry of a privilege and the death of the author. Remedies for infringement of the law included seizure and destruction of the offending copies and damages for the holder of the privilege.

This was the position at the start of the Revolution in 1789 .

As seen above, the system of privileges concerned published editions of literary works. The authors of dramatic works had different problems. Their plays were performed in the years running up to the Revolution by the Comedie française, which by that time had established itself as a complete monopoly, being the only licensed theatre in France. The authors of dramatic works in principle enjoyed the right to be paid royalties for the public performance of their works. However, their position was precarious and they were exploited by the actors. Any right to royalties also ended with the death of the playwright. It was the playwrights who in 1790 led the cause of all authors, when they petitioned the Constitutive Assembly for the abolition of the monopoly of the Comédie française and for the exclusive right to control the performance of their works during their lifetime and for five years thereafter.

\section{The Revolution and the Decrees of 1791 and 1793}

The system of privileges was abolished on 4 August 1789 and the Royal Administration of the Book Trade was disbanded in August $1790 .{ }^{20}$ The following year, the commercial monopoly of the Publishers' and Printers' Guild was abolished. ${ }^{21}$ As Hesse 
explains: "The revolutionaries wanted to free the minds of citizens from censorship and to liberate the means of spreading and exchanging thoughts - literally, the presses and bookshops".22 All this left a vacuum soon to be filled.

At first the vacuum was filled by a burgeoning pirate trade, which put the book publishers at risk and led them to petition the National Assembly to provide them with relief by way of a new regulation of the book trade. It was also filled by a proliferation of seditious and libellous pamphlets.

The National Assembly itself was in the throes of a conservative backlash against the collapse of all regulation of the printed word. In the face of a flood of anonymous, libellous and seditious pamphlet literature, the assembly heard repeated demands for laws requiring authors to sign published works and holding authors accountable for their publications. Thus the economic complaints from publishers converged with the political outcry...

A number of proposals for legislation to control the press and publishing followed, ${ }^{24}$ leading eventually to the adoption of the so-called Revolutionary Decrees of 1791 and 1793 .

\section{The Performance Right}

The Decree of 13-19 January 1791 concerning performances was the first law in France to grant an exclusive right to authors. However, as pointed out by Ginsburg, "the author's concerns clearly [did] not occupy centre stage". ${ }^{25}$ The main goal of the Decree was to introduce the freedom for any citizen to establish a theatre and there to perform the plays of his choice, thus breaking the Comédie francaise's monopoly over the works of Corneille, Molière and Racine. The abolition of that monopoly would also lead to competition between theatres, thus making it easier for playwrights to have their new plays performed. At the same time, the Decree provided that the works of living authors could not be performed in France without their express consent in writing. The penalty for failure to observe this right of the author was forfeiture to him of any revenue derived from the performance. The right of the author lasted for his life and 
accrued to his heirs for five years thereafter. All works of authors dead for more than five years fell into the public domain. ${ }^{26}$

Le Chapelier introduced the draft Decree in a speech much quoted for the eloquence with which he espoused the rights of authors. The fact that he also considered the public interest in connection with these rights has attracted less attention. He began his report by saying that the law should be decided according to the principles of liberty and public property. He said that, in seeking rights for themselves, the dramatic authors recognised the rights of the public and accepted without hesitation that five years after the death of the author works should become public property.

He defined the rights of authors and their rights in relation to those of the public, adding that this was the system operating in England, as follows:

The most sacred, most legitimate, most unassailable, and if I may put it this way, the most personal of all properties, is a work which is the fruit of the imagination of a writer; however, it is a property of a kind quite different from other properties.

When an author has delivered his work to the public, when the work is in the hands of the public at large, so that all educated men may come to know it, assimilate the beauties contained therein and commit to memory the most pleasing passages, it seems that from that moment on the writer has associated the public with his property, or rather has transmitted it to the public outright; however, during the lifetime of the author and for a few years after his death nobody may dispose of the product of his genius without consent. But also, after that fixed period, the property of the public begins, and everybody should be able to print and publish the works which have helped to enlighten the human spirit. ${ }^{27}$ [Emphasis added]

A proposal to increase the term of protection p.m.a. to 10 years was rejected. ${ }^{28}$

A subsequent Decree of 30 August 1792 concerning the rights of dramatic authors made these rights subject to compliance with formalities; the author was obliged to notify the public, at the time of publication of the play, that he had retained the public performance rights. The notice had to be printed at the head of the text of the play and deposited with a notary (Arts. 4-6). Otherwise the author lost his rights. The Decree also reduced the 
term of protection of plays to ten years following publication (Art. 8), as opposed to the period of life plus five years provided for by the 1791 Decree. This revolutionary Decree cannot be said to have advanced the cause of authors' rights; on the contrary, the potential term of protection was greatly reduced.

\section{The Reproduction Right}

The reproduction right of the author obtained recognition with the adoption by the Convention of the Decree of 19-24 July 1793 . It was agreed upon without discussion following a report of de Lakanal as eloquent as that of Le Chapelier, describing the rights of authors as "of all properties the least subject to dispute, the increase of which can neither harm republican equality, nor offend liberty". ${ }^{29}$

The Decree provided that authors of writings of all kinds, composers of music, painters and makers of drawings who make engravings of paintings and drawings, should enjoy during their lifetime the exclusive right to sell, have sold and distribute their works in France and to assign their property therein in whole or in part. Their heirs enjoyed the same rights for a period of 10 years after the death of the author. Provision was also made for the deposit of two copies of works of literature and engravings with the national library and, as Ginsburg has observed, several early court decisions under the 1793 law held that it was the required deposit that gave rise to the copyright. ${ }^{30}$

Penalties for infringement included seizure of unauthorised copies and damages of up to the equivalent of the price of 3,000 copies of the original edition.

The two texts of 1791 and 1793 remained the basic legislation in force in France in the field of authors' rights until 1957, complemented only by case law and a series of legislative texts which modified those of the Revolution as regards term of protection and on matters of detail. 
On the occasion of the second centenary of the French Revolution, the revolutionary Decrees on authors' rights were commemorated inter alia in an article by the distinguished French copyright expert, André Kerever. ${ }^{31}$ He drew attention to the following:

There is often a misconception about Le Chapelier's report which refers to authors' rights as "the most sacred and the most legitimate, the most unassailable and the most personal of all properties", which terms are echoed in Lakanal's report introducing the 1793 Decree where a relationship is established between authors' rights and "natural law". This absolute character of the property right merely concerns non-disclosed ${ }^{32}$ works, for once they have been disclosed, $i . e$. "when an author has handed his work over to the public, he (the author) has made it (the public) a party to his property or, rather, he has transferred his property to it in full".

This was because the Revolutionary legislators, men of 1 aw and order, were bent on providing "stationers" [publishers] or "theatrical companies [disseminators] with a legitimate legal basis against piracy or infringement...."

Thus, far from being personalist in nature, authors' rights as they emerged from the French Revolution were inspired above all by legal and economic considerations. It was the 19 th Century which, through the case law endorsed by the law of 11th March 1957, was to begin to shape out the personalist aspect of authors' rights....

In other words, authors 'rights as sketched out by the French Revolution differ very little from English or American copyright. It could even perhaps be held that the copyright recognised by the American Consitution of 1787 is more personalist than the one stemming from the Decrees of 1791 and 1793 since the American text recognises the authors' exclusive right without restriction whereas the Le Chapelier report insists on the fact that a work which has been disclosed belongs to the "public"....

Thus the French Revolution's "droit d'auteur" was perfectly in line with the corresponding English and American copyrights. At the end of the 18th Century, the right's "continental drift" - creators' rights and right over the copy - had not yet occurred. ${ }^{33}$ It was the $19 \mathrm{th}$ century that was to witness this drift, this separation between an author's right as a right of the person of the creator over the work, considered to be an extension of that person, and the system of copyright which dissociates the right of the person, governed by common law, from the economic right of exploitation of the work.

Kerever's viewpoint is shared by Ginsburg:

While traditional comparisons of French to Anglo-American law assert that France rejected intrumentalist theories in favor of copyright as the just and fair prerogative of creators, research in primary sources prompts a different conclusion. The various legislative texts reveal a hesitating and uneven progress toward protection of authors' rights. Authors are not securely at the core of the new literary property régime; rather, the public plays a major role. The 1791 text appears predominantly preoccupied with the recognition and enlargement of the public domain. [Lakanal's] speech made in favor of the 1793 law emphasizes that protecting authors will not prove detrimental to society. ${ }^{34}$ 


\section{The Development of the Law Between 1793 and 1957}

In the following section of this Chapter, the development of legislation on authors' rights during the next 150 years will be briefly traced. As will be seen, the changes in the law brought about by legislation during this period were not significant. As plaisant noted, referring to the Law of 1793: "for 163 years, with just seven articles, [it] had been enough to protect the whole right of authors in the most extensive manner and in relation to the most unexpected matters." "That this was so is a tribute both to the law itself and to the courts which developed the law of copyright through case law.

\section{Iegislation}

The number and importance of the legislative texts adopted between 1793 and 1956 relevant to authors' rights and the book trade is not substantial. It is interesting to note, however, that in several of these texts the object appears to be more to control the book trade than to protect the rights of authors. ${ }^{36}$

A Decree of 15 June 1795 (25 prairial, year III) provided that the Commissioners of police and justices of the peace were responsible for enforcing the rights of authors granted by the 1793 Decree.

Two Decrees of 22 March 1805 ( 1 germinal, year XIII) and of 8 June 1806 regulated the rights of the owners of posthumous works and prohibited publishing such works together with works already in the public domain in order to prevent such owners obtaining "in their favour a sort of privilege for the sale of works which have become the property of the public".

A Decree of 5 February 1810 guaranteed the property rights of an author for himself and his wife for their lifetimes and for his children for 20 years after his death. Other heirs only benefitted for 10 years. It also contained provisions regulating the printing and book trade in response to a report from the Police Minister which stated: the aim to be achieved by a law on 
the book trade, is: (1) to prevent counterfeits which attack property, discourage industry and ruin commerce; (2) to prevent the publication of writings which could disturb public order or corrupt morals.

The Penal Code of 1810 made counterfeiting a misdemeanour and set the level of fines to be paid by those found guilty thereof.

A Law of 6 May 1841 and an Order of 13 December 1842, concerning customs, regulated the importation of books into France. Where there was a presumption that copies of a book were pirated, importation was suspended and the matter referred to the Interior Ministry for decision within 40 days.

A Law of 3 August 1844 guaranteed the widows and children of authors of dramatic works the right to authorise the public performance thereof for twenty years p.m.a. in conformity with the Decree of 5 February 1810.

A Decree of 28 and 30 March 1852 conferred protection on works published abroad, making it a misdemeanor to counterfeit such works in France. Thus, the protection of the law was extended to foreign authors unconditionally. Similarly, the importation of pirated copies of French works from abroad was prohibited. This Decree was abrogated by the 1957 Law, when the French legislature decided to bring to an end this period of unilateral generosity.

A Law of 8-19 April 1854 gave widows of authors, composers and artists the rights in their deceased husband's works for the rest of their own lives. Children were entitled to enjoy these rights for 30 years after the death of the last surviving parent.

Decrees of 9 December 1857 and 29 October 1887 extended the laws on literary property to the colonies.

A Law of 16 May 1866 gave a special exemption for the reproduction without authorisation of music by mechanical musical instruments. This was subsequently revoked on 10 November 1917. 
On $14 \mathrm{July}$ 1866, the duration of the rights of authors, their heirs and successors-in-title was set at 50 years p.m.a. A widow lost her rights in her late husband's works if legally separated at the time of his death or on remarriage.

A Law of 29 July 1881 provided for the deposit of two copies of all books and other printed publications with the national collections as well as of three copies of prints, engravings, sheet music and of all reproductions of works expressed otherwise than in the printed word.

The Law of 11 March 1902 extended the protection of the Law of 19-24 July 1793 to the works of sculptors and designers, "whatever the merit and purpose of the work".

A Law of 9 April 1910 regarding the rights of authors of artistic works provided that: "Subject to agreement to the contrary, the disposal of a work of art does not result in the disposal of the right of reproduction".

On 20 May 1920, artists were granted a 'droit de suite' (artists' resale right) meaning that they became entitled to receive a percentage of the sales price of works of art sold at public auctions.

On 19 May 1925, the protection afforded to authors' rights was dissociated from the formality requiring legal deposit of copies of works.

On 25 February 1956, the National Fund for Letters (Caisse nationale des lettres) was established and a public paying domain introduced.

As Dock has pointed out: "On the whole, the legislation on authors' rights remained laconic. The upheavals which affected the dissemination of creative works as a result of the advent of records, films, radio and television were not the subject of any legislation for a long time". ${ }^{37}$ 


\section{Case Law}

A number of important principles emerged from the case law over the years. The merit or literary importance of a work was held to have no influence on rights. Thus, all works regardless of their quality were protected. The courts also took a broad view of what could be considered a literary or artistic work; it had only to be the result of personal effort and work of the mind. Thus case law afforded protection inter alia to translations, theatrical adaptations, ballet scenarios, atlases, maps, plans, newspaper articles, compilations, dictionaries, guides, catalogues, prospectuses, etc. The form of the work, not the ideas contained therein, was protected. The same rules applied to musical works; arrangements and variations on works in the public domain were protected. As regards artistic works, the courts applied the 1793 Law "to all works of the graphic and plastic arts without distinction, provided it was the result of personal effort, however minimal the effort and however modest the personality". ${ }^{38}$

The protection of photographs was much disputed. The courts were divided. According to one view, propounded in a series of cases beginning in 1863, a photograph was not an artistic work because it resulted from a mechanical process without recourse to the talent of an artist. According to a second line of cases, beginning also in 1863, photographs were considered to be productions of the mind within the meaning of the law. The photographer was responsible for deciding how the subject should be photographed and exposed to the light; in so doing he exercised taste, discernment and skill and therefore the resulting photograph represented a work of the mind. ${ }^{39}$ According to a third approach, the court should decide case by case whether a particular photograph for which protection was sought merited protection as an artistic work. This was evidently the least satisfactory approach, introducing as it did subjective, artistic criteria for protection, contrary to the spirit of the 1793 Law, which as seen above protected works without regard to their literary or artistic merit. 
In 1905, it was held that a cinematographic film was an artistic work protected under the 1793 Law. ${ }^{40}$

\section{Exceptions}

The making of manuscript copies for the personal use of the individual making the copy was not considered an infringement of copyright, whereas a manuscript copy made for commercial purposes was. In 1928, it was held that the copying of extracts of works for use in schools was not an infringement (Paris, 22 March 1928). Quotation for the purpose of literary criticism or in support of or against an argument was permitted (Civil Court of the Seine, 11 March 1897), as was quotation for the purpose of historical documentation, teaching and information.

\section{Moral Rights}

The concept of the moral rights of authors developed in France in the last quarter of the nineteenth century and the first half of this century. Pouillet described these rights as being:

the right, for the writer and artist, to create and to have his work respected.... Differences of opinion exist as to its basis. Some consider it to be the very heart of the right of the author, others see in it only one aspect of that right; others distinguish it from the right of reproduction and give it a different basis, arguing that it is derived from the right that every man has to respect for his personality. ${ }^{41}$

Desbois described the moral right as it had developed through case law prior to the 1957 Law, as follows:

In a word, on first publication, the work enters the community, and a fortiori, the national heritage, but the economic exploitation thereof will be submitted to the influence or rather the supremacy of the moral right: the exercise of the latter will temper the effect of the transfer, in order to ensure respect for the links which unite the work to the personality of the creator. ${ }^{42}$

Moral rights were to find their apotheosis in the 1957 Law. 


\section{Proposals for Reform in the Nineteenth Century - Perpetual Rights} versus the Public Interest

In the course of the nineteenth century, the French government appointed a number of committees to look into and propose reform of the revolutionary laws on authors' rights. An account of the work of these committees by Jean Matthyssens published in 1954 relates that these committees all paid attention to the public interest, ${ }^{43}$ as a study of the sources confirms.

In 1825, a committee was set up under the Chairmanship of the Vicomte de la Rochefoucault. According to Matthyssens: "The King insisted that this Committee should make every effort to reconcile the interests of authors and artists, and equally those of the public and trade".

The question of making authors' rights perpetual arose once more. In its report to the king dated 1828, the Committee rejected perpetual rights for the following reasons:

Such a privilege existed nowhere else; it would harm education by a monopoly lasting too long; it would become either onerous for the public, or illusory for the families; it would often falsely interpret the intentions of the author himself, who by publishing his work, had hoped that editions would increase and multiply easily after him. It therefore appeared to us, Sire, that while the present term of the exclusive right should be extended there should be a limit thereto.

The Committee recommended a period of protection of 50 years p.m.a., commenting that "the provisions of the draft are the most favourable to their authors and their families that have ever been made in any country. They will stimulate talented men to compose great and serious works, in the certainty that their families will enjoy an honourable patrimony for many years". ${ }^{44}$

Nothing came of the proposals of the Committee.

A further Committee, this time under the chairmanship of the Comte de Ségur, was appointed in 1836. Again the question of perpetual rights was discussed. Although it seems the Committee "leaned towards perpetuity", it rejected it, expressing: 
fears that such a system would establish to the advantage of the authors' heirs or his assigns, a kind of everlasting tax on publishers, thus increasing the mercenary value of the books and putting a premium on foreign pirating, finally creating costly difficulties, awkward for trade and almost insurmountable as to assessment and the collection of this new tax.... It was then a question for the Committee of fixing fair limits in the interests of all to the right of ownership of the various heirs of the authors.

The Committee settled in the end for 50 years p.m.a. but was concerned to reconcile the rights of an authors' heirs with the rights of the public to the enjoyment of works. The Committee proposed that, in the public interest, if an heir refused to authorize publication of a work, fifteen years after the death of the author the matter could be referred to the courts for an auction of the rights.

Again, nothing came of the Committee's report.

Early in 1839, the Minister of Education, M. de Salvandy, 'was charged with making a report to the chambre des Pairs. "The public interest seems to have been the first care of the Minister". ${ }^{45}$

Recommending a period of protection of 30 years p.m.a., M. de Salvandy said:

Is there not another interest than that of the author and his children? Is there not another acquired right than theirs? Does the book really belong to them only? Can the verses of Racine be the exclusive property of a family, do they not belong to us all?... Manifestly, literary ownership has its particular character inasmuch as it is indivisible between the parties entitled of the author [sic: i.e. heirs] and the community itself; that besides the right of some to exploit, there is the right of all to enjoy.

In May 1839, the Vicomte Siméon presented a draft Law relating to the rights of authors in their production in letters and arts. He also proposed a period of protection of 30 years p.m.a., giving the following reasons:

The government found the duration of 50 years proposed by the Committees of 1825 and 1836 too long. They consider that the exclusive right of publishing thus prolonged, instead of serving the interests of the authors' descendants, would encourage pirating, just as prohibition in trade matters encourages smuggling. The sale of books is a trade that must not be over-shackled if it is to prosper. 
In addition, it is of interest to note that siméon also stated that "the right guaranteed to authors was not a natural right, but a privilege resulting from a benevolent concession of the law".

This draft was never submitted to the Chamber of Deputies.

In 1841, M. Villemain, Minister of Education, was asked to take up the matter once more. M. de Lamartine took part in the debate and persuaded his colleagues to propose a period of protection of 50 years p.m.a. Again, nothing came of the proposals for reform.

It was not until 1861 that a new Committee was set up of which M. Walewski was rapporteur and which reported to the Emperor in 1863. ${ }^{46}$ This Committee favoured perpetual rights: "the Committee does not limit itself to adding as a new favour a few years to those that the present legislation grants as a benevolent remuneration, it grants perpetuity without which there is no true ownership". ${ }^{47}$ However, referring to the need to reconcile the interests of authors and their families with the requirements of the public interest, the committee recommended 50 years protection p.m.a. "as a major concession to the public interest", followed by a right to a royalty of $5 \%$ on the sales price of reproductions of works and, in the case of dramatic works, half the amount of royalties paid to living authors. ${ }^{48}$

The question of duration was finally settled in 1866 by the Law of $14 \mathrm{July,}$ which fixed the duration of authors' rights at 50 years p.m.a. The argument for perpetual rights was lost for the moment only to be revived a century later in the perpetual moral rights granted by the 1957 Law. Unlike all the preceding drafts, which had aimed at a general revision of the law, the 1866 Law dealt only with the question of duration.

\section{The Evolution of French Concepts of Authors' Rights}

Case law solved some of the problems posed by new technology but, when a new Law on authors' rights was finally adopted on 11 March 
1957, the legislator failed to address many of these problems. Desbois described the philosophy of the 1957 Law as being to "respect and develop the traditional principles of the French concepts of authors' rights". ${ }^{49}$

The question may be posed, "What were the traditional principles of the French concepts of authors' rights" evoked by Desbois in 1957? How had these concepts evolved in the 150 years between the revolutionary laws of 1791 and 1793 and the Law on authors' rights of 1957 ?

As we have seen, the aims and objectives of the revolutionary laws did not differ greatly from the pre-existing copyright laws of England and the United States of America. What Kerever has called the authors' rights "continental drift - creator's right and right over the copy" - did not emerge from the legislative texts briefly described above but from case law and out of the development of the theory of moral rights by the courts from the last quarter of the nineteenth century onwards. The only clue the legislation described above gives to the drift lies in the laws which steadily increased the period of protection of the author and, after his death, of his widow and children.

Indeed, as seen above, until the Law of 1866 introduced a period of protection of 50 years p.m.a., so ending the controversy, there were continual voices calling for authors' rights to be perpetual, a demand which caused attention to be given to the nature of authors' rights.

The Rochefoucauld Committee on Literary Property in its 1826 report observed that there was no unanimous view of the nature of authors' rights:

Two different ways of considering these rights have given rise to two opposed views. Some consider the creation of a literary work as establishing in favour of the author a property right which confers on him, together with the freedom to dispose of his work, the exclusive and perpetual benefit of the profits derived from its publication. Others see in this publication of ideas a hommage to society, which therefore becomes the owmer of the published work, but has an obligation to indemnify the author for his work by the grant to him of certain advantages. 
Renouard, whose personal opinion was that a balance should be struck between the interests of authors and those of the public, and who feared that a property right would tip the balance too far in favour of authors, ${ }^{51}$ described the state of the law in 1838 as follows: "Our legislation concerning intellectual property is incoherent and, above all, incomplete; however, at least it has a stable basis, and the establishment of rights limited in time has resolved the problem of conciliating the rights of authors with those of society". 52

In 1881, the Cour de Cassation stated: "literary and artistic property, which is essentially personal property, has the same characteristics and should be treated in the same way as any other kind of property, with the exception of the limit which the public interest has imposed on its duration". 53

In relation to this definition, Desbois noted that, at that time, the analysis of moral rights had not been developed sufficiently for the Supreme Court to take account of it in parallel with economic rights. ${ }^{54}$

Pouillet, writing in 1908, gave the following definition of author's rights:

The right of the author is the privilege recognised by the law to exploit his work, and reap all the benefits which the work admits of, to the exclusion of all others for a certain period. Once that period has expired, the work falls into the public domain and everybody is free to exploit it without restriction. ${ }^{55}$

For Pouillet, the right was a property right, albeit one of a special character, subject to special regulation. While having its source in natural law, it required different treatment to other types of property. As regards the argument that, since the author's right was a property right, it should be perpetual, Pouillet remarked the following:

Did the legislator not have the the right, when for the first time he recognised and afforded protection to this property right, to lay down the conditions to which he considered it necessary to subject that protection, in the general interest.... Is it not natural, therefore, 
for the legislator, in the general interest, in order to safeguard the right of the public to the intellectual enjoyment of the work, to refuse to endorse perpetual authors' rights? ${ }^{56}$ [Emphasis added]

Thus, at the turn of the present century, it would seem that authors' rights were regarded as special property rights, granted by the state, i.e. not arising automatically out of natural law, and limited in duration in the public interest.

\section{The Twentieth Century}

\section{The Road to Reform: The Draft Law of 1945}

In August 1945, a Committee on Intellectual Property established under the chairmanship of Professor Jean Escarra, submitted draft legislation to the government. The draft was accompanied by a letter which stated the aims of the Committee:

Thus the present draft is first of all a codification of the right of literary and artistic ownership: it is constantly inspired in the final reading of each text, by the concern to use the copyright as a means of favouring literary and artistic creation and of insuring the integrity of works each of which has its share of originality."

This was the first draft of what in due course became the 1957 Law. In the meantime, successive drafts were considered by the various government departments concerned and discussed with interested parties. It was not until 9 June 1954 that a bill was finally tabled at the National Assembly and that the work of the Committee came to an end.

\section{The 1957 Law on Literary and Artistic Property}

The Parliamentary debates which led to the adoption of the new Law on 11 March 1957 thus lasted three years. The preamble of the bill had stated its object as being:

To codify the case law that has been created in the last century and a half concerning authors' rights and to lay down in a definitive text the latest state of French doctrine in this field; to answer also to the need felt by intellectual creators to be protected, taking into 
account the new economic and technical conditions and also the new forms of art which have come into being since the legislation of the French Revolution. ${ }^{58}$

The Vice-President and Rapporteur of the Intellectual Property Committee of the Government, Marcel Boutet, stated in a commentary on the new Law: "French law had from the beginning to choose between two intellectual tendencies; the one which attributed the pre-eminence to the person of the author and the other that envisaged above all the purpose of the book, that is to say its communication to the public".

According to him, the author's right:

Born during the French Revolution which proclaimed the eminent dignity of the human person ... the texts of 1791 and 1793 could not fail to give precedence to the creator. It is the creation, intellectual manifestation of the personality, that invests the author with a number of rights, without inasmuch injuring public interests.

The aim of the legislation was:

less to seek to innovate than to codify the existing law.... Effectively, the new law presents no modification in structure with respect to the old texts and to the case law built up over a century and a half; it is still the spirit of the original doctrine of copyright that goes on living.

It is thus that the legislation of 1957 carries into effect the synthesis of the author's rights and the interests of the public, in the preeminence of the creator. ${ }^{59}$

The references to the interests of the public in the passages cited above are among the very few such references that the author has found in the reports on the preparatory work leading to the adoption of the 1957 Law and in the commentaries which followed on from its adoption. A lone voice in the Council of the Republic (the equivalent of the present senate under the 1946 Constitution) spoke briefly during the parliamentary debate of the public interest and the role of copyright in the dissemination of works to the public. ${ }^{60}$ Even where reference is made to the interests of the public, these are not defined and there is no discussion of the need to establish a balance between the rights of authors and the interests of the public. In assessing the new Law, most commentators took as their starting point the question posed by Alphonse Tournier "whether in the 
interests of authors it has conserved the achievements of the old law and the so-called legacy of the past". ${ }^{61}$ Tournier, however, also considered whether, and to what extent, it had taken into account new ideas and new facts which had emerged in the modern world. Tournier refers to the public interest only in relation to certain limitations imposed by the law on the rights of authors:

Whereas the legislator showed the utmost concern for the author, he was obliged to take account of 'the author's social role', and, therefore, to limit him in the exercise of his rights. The diffusive power of modern technical devices is such that literary and artistic productions have become an integral part of the daily life of the masses, and the author must therefore make certain concessions in the public interest.

According to Desbois, the 1957 Law raised the moral right "to the first place because, on the juridical level, its mission is to protect the personality of the author through the work."

Hence the new Law in its Art. 1 stressed that:

The author of an intellectual work shall, by the mere fact of its creation, enjoy a property. The legislator does not intervene to attribute to the writer, the artist, the composer, an arbitrary monopoly, under the influence of considerations of opportunity, in order to stimulate the activity of men of letters and artists in the interest of the collectivity; the author's rights exist independently of his [the legislator's] intervention. ${ }^{62}$

It will be seen that, in Desbois' opinion, the 1957 Law by giving pride of place to moral rights had recognised that authors' rights exist independently of the intervention of the legislator. This was a new approach in French copyright law. As seen above, up to and including the early part of the present century authors' rights were regarded as special property rights, granted by the state.

The 1957 Law consolidated the existing legislation and case law. As discussed above, moral rights were introduced here for the first time in French legislation, the author enjoying the right to respect for his name, his authorship and his work. The right was attached to his person and was to be perpetual, inalienable and imprescriptible (Art. 6). The non-limitative list of protected works embraced all those works previously recognised 
by the courts as protected by the revolutionary laws and included cinematographic works and works produced by a process analagous to cinematography. ${ }^{63}$ Photographic works were protected to the extent that they were of an artistic or documentary character as were other works of a like character produced by a process analagous to photography (Art. 3 ). Authorship was confined to physical persons. Legal entities could not be regarded as authors except in the case of a collective work. Thus authorship of a cinematographic work vested in the co-authors (of the script, adaptation, dialogue, music and the director), although the Law introduced a legal presumption of assignment to the producer of the right to exploitation of the work (Art. 17). Case law had previously recognised the producer as the author. ${ }^{64}$

The economic rights of the author included the performance right and the right of reproduction. Performance was defined as consisting in the direct communication of the work to the public by means of public recitation, musical and dramatic performance, public presentation, dissemination by any method of words, sounds or images, public projection and broadcast transmission (Arts. 26 and 27). The principle that the author should benefit from a proportional participation in the receipts resulting from the sale or exploitation of a work was laid down (Art. 35). Detailed rules were established with regard to performance and publishing contracts for the protection of authors.

As mentioned above, in the public interest, a number of limitations on the rights of authors were laid down in the Law. Permitted uses included: free, private performances produced exclusively within the family circle; copies or reproductions for the private use of the copyist; analyses and quotations made for critical, educational, scientific, etc. reasons or for review; publication of public speeches in the press and in broadcast programmes; parodies, pastiches and caricatures (Art. 41). Certain recordings of broadcasts were also permitted "by reason of the national interest which they may represent or of their documentary character" for preservation in official archives (Art. 45). 


\title{
The Public Interest in the Debate for Reform and the 1985 Law
}

Commenting on the adoption of the 1985 Law on Authors' Rights and on the Rights of Performers, Producers of Phonograms and Videograms and Audiovisual Communication Enterprises, the Minister of Culture, Jack Lang, set out the philosophy of the Government of the day with regard to these rights, saying inter alia:

\begin{abstract}
This reform is one of the essential juridical aspects of an overall strategy aimed at endowing France with the material and intellectual means of meeting the challenges confronting it in the cultural sphere. It behoves the national community to apply itself to fostering the creation of intellectual works. The state does so by appropriating considerable resources and by organising suitable institutions to provide for needs that the market alone cannot meet.

It does so also by providing its partners in the private sector with rules of the game that are clear and adapted to technological and social developments. Such is the purpose of the law....

In order to do this, the technical upheavals that have occurred during the past thirty years had to be taken into account and the economic and financial conditions required to foster creation had to be established....

This draft law drew its inspiration from three principles:

- to facilitate concerted action among those participating in the creation of intellectual works;

- to provide them with one of the most advanced systems of legal protection in the world;

- to foster the dissemination of works to the public. ${ }^{65}$
\end{abstract}

M. Lang had introduced the bill into Parliament with the same words in his exposé des motifs. He made therein a number of other points relevant to the public interest. In respect of Part II of the bill concerning related rights he remarked:

It is in this field that there is the most acute need to legislate. It is a question of conferring rights [on performers, producers and audiovisual communication enterprises] in order to enable them to master the economic and social consequences of the rapid development of new means of communication without however obstructing their use.

With reference to Part IV, which established rules governing the operation of collecting societies for the first time, subjecting their activities to the approval of the Ministry of Culture, he observed that this was "necessary in order to guard the authors, performers and producers as well as the broadcasters and the public against possible abuses in the exercise of their rights by the societies". ${ }^{66}$ 
During a debate in the Senate in April 1985, M. Lang expressed the belief that the bill represented a balance between the needs of the various interested parties, including those of the public interest. ${ }^{67}$

The rapporteur of the Committee of the National Assembly, M. Alain Richard, in his report on the bill said:

The main purpose of the bill (no. 2169) is to adapt the legislation on literary and artistic property to technical, economic and social developments, recognising moreover specific rights in favour of those auxiliaries of creation, the performers and producers.... It is incumbent on the state to fix the respective rights of the various partners in intellectual creation, with the aim of promoting a large measure of cooperation, ensuring that the interested parties obtain appropriate legal protection and finally of encouraging the exploitation of the national heritage. ${ }^{68}$

Reference may also be made to the Report of M. Charles Jolibois, rapporteur of the responsible senate Committee on the occasion of the second reading of the bill. He stated that:

The senate, throughout its consideration of the draft law, has endeavoured never to lose sight of the fact that authors' rights and the rights related thereto should be exercised within a competitive French production. It is of course a question of being in a position to produce works competitively as against competitors abroad and, moreover, to avoid blockages in the mechanism of production. ${ }^{69}$

Likewise, the report of $M$. Charles Metzinger, on behalf of the Committee for Cultural, Family and Social Affairs, stressed the fact that the bill aimed to ensure a favourable environment for creativity by adapting "our legislation to the technological upheavals which have taken place over the past thirty years and by creating the economic and financial conditions which are essential for the furtherance of creativity."70

It is important to note that the 1985 Law did not replace the 1957 Law but amended it. It extended the definition of cinematographic works to include "other works consisting of moving sequences of images, with or without sound, together referred to as audiovisual works". The limitation on the protection of photographs to those "of an artistic or documentary character" was removed. Graphical and typographical works and computer programs were protected. Producers of audiovisual works 
were given protection and their rights defined (the presumption of assignment to the producer of the exclusive exploitation rights in the audiovisual work was confirmed). The term of protection for musical compositions was extended to seventy years. Part II of the Law dealt with so-called neighbouring or related rights, introducing for the first time protection for performers and producers of phonograms and videograms. Moral rights were recognised for performers as well as the right to authorise the fixation, reproduction and communication to the public of performances. The authorisation of producers of phonograms and videograms was required for reproduction, making available to the public by way of sale, exchange or rental, or communication to the public of their phonograms or videograms. However, neither the producer nor the performer could oppose the broadcasting or public performance of a phonogram, such use entitling them only to remuneration. These rights were granted for a period of fifty years from publication or performance. The Law also introduced remuneration to be paid to authors, performers and producers for the private copying of phonograms and videograms (Part III). Part IV introduced rules governing the administration of collection and distribution societies. All activities in respect of videograms intended for the private use of the general public were made subject to supervision by the National Cinematographic Centre (Part VI). Finally, the sanctions and penalties for infringement in the Penal Code were updated and strengthened.

The increase in the period of protection of musical works to 70 years p.m.a. was, as reported by Kerever,

introduced during parliamentary discussion of the government bill without eliciting any major theoretical debate. The Parliament appeared to be more sensitive to publishers' problems than to the author's situation. The idea was to enable publishers to amortize investments, larger for certain works than for others, by lengthening the term of protection. ${ }^{71}$

According to $M$. Richard's report on the second reading of the National Assembly, the senate, which had introduced the amendment, had also been influenced by the fact that a number of France's competitors granted a longer period of protection than 
50 years. ${ }^{72}$ A proposal by the National Assembly to extend the term of protection of all literary and artistic works was rejected by the Senate. ${ }^{73}$

\section{Statutory Exceptions to Protection}

As already mentioned above, ${ }^{74}$ the 1957 Law had imposed certain statutory limitations on the rights of authors in what Tournier described as "certain concessions in the public interest". 75 These limitations were laid down in Art. 41 of the 1957 Law and are summarised above. The 1985 Law modified the provisions of Art. 41 of the 1957 Law in only two respects. First, it extended the exception allowing broadcasting of public speeches so as to cover any means of telecommunication. ${ }^{76}$ Second, and of major importance, the exception permitting the making of copies for the private use of the copyist ${ }^{77}$ was restricted in that the authors and performers of works fixed on phonograms or videograms: and the producers of such phonograms or videograms were given the right to receive remuneration for the reproduction of works for private use. ${ }^{78}$ Thus, it remains legal for an individual to make a copy for his own use but in consideration therefor the right owners are entitled to be remunerated for the making of the copy. As $M$. Richard pointed out in his report of the committee of the National Assembly on the Bill, ${ }^{79}$ it was necessary to provide such a system of remuneration because: "the private copying of works had the result not only of reducing the remuneration due individually to each author or auxiliary of creation, but also of reducing the activity of the cultural and artistic professions and hence the level of employment". For this reason, also, the law requires that $25 \%$ of the amounts derived from the remuneration for private copying should be used for activities aimed at promoting creativity, live entertainment and the training of performers.

\section{Recent Developments}

Since the 1985 Law was adopted, there have been a number of legislative developments. 
In 1992, the laws on industrial and literary and artistic property were codified in one text, the Intellectual Property Code of 1 July of that year. The new code did not make substantive changes to the law, being designed only to group together in one text all previous laws in the field of intellectual property. ${ }^{80}$ It is of interest, however, to note that the code expressly defines both authors' rights and related rights as literary and artistic property. ${ }^{81}$

Increased protection against infringement of all intellectual property, including authors' and related rights, was introduced in $1994 .^{82}$ New maximum penalties have been imposed of up to two years imprisonment and a fine of up to $\operatorname{FFr} 1$ million.

The first new law to implement European Union legislation in the field of authors' and related rights was also adopted in 1994 . This concerned amending the code to comply with the EC Directive on the legal protection of computer programs. ${ }^{83}$

In 1995, the Code was further amended to provide for compulsory collective administration of rights with respect to reprographic reproduction of works. ${ }^{84}$ Only paper copies made for non-commercial use are covered by the new arrangements. It also dealt with the distribution of royalties payable to foreign authors from private copying of their work on blank audio and video tapes.

\section{Conclusion}

The above analysis has shown that, like in England and the United States of America, concern for the public interest was an important consideration in the revolutionary French Decrees of 1791 and 1793, which, while giving recognition to the rights of authors, also laid emphasis on the rights of the public to access to those works and the importance of public education. As discussed above, a number of commentators have drawn attention to the prominence the revolutionary Decrees of 1791 and 1793 accorded to the public interest and to their similarity in this respect to Anglo-American notions of intellectual property. 
Renouard, writing in 1838, described the system of copyright in France as he saw it at the time, stating that authors were:

workers and not property owners; if the laws ensure them exclusive exploitation of their works, it is by virtue of a positive grant of civil law and of a tacit contract which, at the moment of publication, intervenes between the public and the author. It is by the establishment of a privilege, created as a legitimate and fair compensation, that the full and free exploitation of a published work is forbidden to all persons composing the public. This is the system of the law of 19 July $1793 .^{85}$

Thus, the revolutionary Decrees had reflected the positivist approach to authors' rights, according to which the law is a creation of the state.

In the course of the next one hundred and fifty years, the law relating to the rights of authors developed gradually. "Both legal writers and the courts relied on a few lines of these [revolutionary] Decrees to adapt authors' rights to the new techniques of communication and reproduction which entirely transformed social and cultural life". ${ }^{86}$ During this gradual process, the theoretical approach to authors' rights in France changed in emphasis, the naturalist approach according to which a work is inseparable from the person who has created it, it being an expression of his personality, gaining in influence. Thus authors' rights came to be considered as personal and inalienable rights, rooted in natural law and belonging to the actual physical person who creates a work. It was advocates of the naturalist approach who attempted to introduce perpetual rights for authors during the nineteenth century. It was also the influence of personalist ideas in copyright theory that led to the development through case law of the concept of moral rights. In the naturalist approach, the rights of authors take precedence over the public interest.

However, the naturalist approach did not completely dominate the work of the various committees which considered proposals for reform during the nineteenth century. These committees continued to take account of the public interest. Thus, the 1825 Rochefoucault Committee's terms of reference, for example, called on it "to reconcile the interests of authors and artists, and 
equally those of the public and trade". The many, repeated debates on the question of perpetual rights for authors, which lasted until 1866, turned on the need to achieve a balance between the interests of the authors, those of the publishers, the rights of the public to access works and avoiding impediments to trade in books, such as piracy and smuggling.

It is pertinent to note that, in 1937, the public interest was evoked by Escarra, Rault and Hepp in their joint work on the French law on authors' rights. They made the following observations on the subject:

All legislation of this kind must essentially represent a labour of seeking to reconcile equally respectable interests.... Moreover, one forgets too often that the battle - if battle there is - is not limited to the author on the one hand and the publisher on the other. There is a third interested party, namely, the public. It is a first truth to affirm that the general public must be put in a position to enjoy, in the most favourable possible conditions, the fruits of literary and artistic creation. ${ }^{8}$

By the time that the Law of 11 March 1957 was adopted, in French copyright theory the interests of the author had gained ascendancy over those of the public. The moral rights of the author were given pride of place so as to protect the personality of the author through the work. Desbois described the law as having been based on three guiding principles, which ensured the homogeneity and solidity of its construction; these were: "1. authors rights arise out of the act of intellectual creation alone; 2. authors' rights come into being in the person or patrimony of the creator; 3. moral rights take priority". He added that these rights resulted from the natural order, and arose independently of the intervention of the legislator. ${ }^{88}$

The public interest at that time seems only to have been taken into account in relation to limitations upon the rights of authors. It was recognised that the author had a social role and must therefore make certain concessions in the public interest.

By 1985, the public interest had reappeared as an issue in the debate on the reform of the law. As quoted above, ${ }^{89}$ the Minister of Culture, Jack Lang, emphasised at the time that the national 
community had a duty to foster the creation of intellectual works and that it was necessary to establish the economic and financial conditions required to do so. The three principles on which the law was based did not place authors in a pre-eminent position; these were:

- to facilitate concerted action among those participating in the creation of intellectual works;

- to provide them with one of the most advanced systems of legal protection in the world;

- to foster the dissemination of works to the public.

The copyright philosophy of the government of the day, expressed by $M$. Lang, would not have been surprising coming from a British or US Minister. It laid emphasis on the promotion of creativity and the dissemination of works in the public interest, concepts which had been absent for many years from copyright debate in France. By contrast, reference may be made to Desbois' 1978 description of the nature of authors' rights in France. Making a distinction between government policy as applied to patents for invention and its policy towards authors' rights, he stated:

[The patent system] is in complete opposition to that of authors' rights, since the emphasis is laid on the public interest as opposed to the private interest of inventors. Under the French law, literary and artistic property rights are not considered as instruments of political policy, inspired by considerations of expediency or by concern to stimulate intellectual creativity; they represent the expression of the respect which is due to works of the mind and their creators. ${ }^{90}$

While there is no doubt that the 1985 Law fully respects the rights of authors, it is also clear that the government of the day also once again gave recognition to the positive role that copyright law plays in the public interest, by furthering creativity and promoting access by the public to copyright works. As Kerever has observed: "The social usefulness of copyright consists in providing an economic basis for creation. This usefulness is still there at the end of the 20 th century."91

This conclusion is confirmed by A. and H.-J. Lucas, writing in 1994 on the historical rationale for authors' rights in France. 
They emphasise the preeminence traditionally afforded to the author; these rights are centered on the person of the author, which explains the references in the literature to natural rights and provides the justification for moral rights. However, they acknowledge that other justifications have also played their part. Authors' economic rights have a dual basis, the reward for labour and respect for human personality. The principle of reward for labour naturally leads to authors' rights being regarded as an encouragement to creativity, a function which both the revolutionary legislator and the legislator of 1985 had in mind. ${ }^{92}$ They further draw attention to the need for a balance to be struck between the interests of authors and the public. "The French personalist conception of course implies a hierarchy of interests in principle favourable to the author, which is not found in the copyright tradition. But the public interest is nonetheless taken into account." 93

This study has shown that the original aims and objectives of the French revolutionary laws on copyright did not differ as extensively as has been suggested by most commentators from the Anglo-American approach. As no less an authority than Kerever has recognised: "Far from being personalist in nature, authors" rights as they emerged from the French revolution were inspired above all by legal and economic considerations.... Thus the French revolution's droit d'auteur was perfectly in line with the corresponding English and American copyrights". ${ }^{94}$

Ginsburg's examination of the French revolutionary sources provides powerful evidence that:

the differences between the U.S. and French copyright systems are in fact neither as extensive nor as venerable as typically described. In particular, despite the conventional portrayal, the French revolutionary laws did not articulate or implement a conception of copyright substantially divergent from that of the régimes across the Channel and across the Atlantic. The French revolutionary sources themselves cast doubt upon the assumed author-centrism of the initial French copyright legislation. The speeches in the revolutionary assemblies, the texts of the laws, and the court decisions construing the laws, all indicate at the least a strong instrumentalist undercurrent to the French Decrees of 1791 and $1793 .{ }^{95}$

She concluded that: "The first framers of copyright laws, both in France and in the US sought primarily to encourage the 
creation of and investment in the production of works furthering national, social goals". ${ }^{96}$

At the outset, the French law of copyright protected the rights of authors of works regardless of the aesthetic merit of the work. Article 1 of the 1793 law referred to "writings of any kind". As Laligant has shown, this "implied that the law sought to protect any piece of writing if its production had required an intellectual effort on the author's part.... In view of the expression's general nature, the courts affirmed and reaffirmed that compilations of all sorts enjoyed the protection afforded by the law", including dictionaries, guidebooks, catalogues, almanacs, directories, tariffs and abridgements and all those other works described in the 19 th century as "even the most paltry productions". ${ }^{97}$ In this broad interpretation, the revolutionary laws and the French courts did not differ from the English and American approach.

Laligant points out that it was not until the second half of the nineteenth century that emphasis began to be placed on the aesthetic character of works in France:

It was actually around 1860 -. ... when an unprecedented importance began at last to be attached to art...-- that legal literature started to refer less to the law on infringements or the rights of authors and more to literary and artistic property and to affirm more and more frequently that the natural and original calling of the literary and artistic property right was to protect works of the belles-lettres and the beaux-arts, that is to say works of an aesthetic nature. ${ }^{98}$

Thus, the concept that to be deemed a work of authorship protectable by literary and artistic property, a creation had to be aesthetic in nature, was a development of the late nineteenth century. This subsequently had a profound influence on copyright theory in France and became an article of faith for many distinguished commentators, including Plaisant, in whose opinion: "in the field of authors' rights, it is considered that the requisite originality must be aesthetic in nature, even if Article 2 of the Law of 11 March 1957 protects works regardless of their kind, form of expression, merit or purpose". ${ }^{99}$ (Emphasis added) 
Taken together with the personalist conception of authors' rights, which, as we have seen, had gained ascendancy in France by the turn of this century, and according to which only physical persons could be considered authors, the idea that to be protected a work must have an intrinsic aesthetic or artistic value is a further basic reason for the divergences which developed between the French and Anglo-American copyright systems during the first half of the twentieth century. The latter had less difficulties in extending copyright to new forms of "writings", such as designs and models, films, phonograms, computer programs and so on. French jurists were slower to afford these protection not only because they were often the work of more than one individual but also, in part, because their artistic value, as opposed to their commercial interest, was in doubt.

Laligant asserts that the aesthetic criterion rests on what he describes as:

a historical misinterpretation. Indeed, what authors' rights were always meant to protect is any expression of thought embodied in a form, and not certain expressions of thought only: namely those testifying to aesthetic concerns. Moreover, the irrelevance of the aesthetic character of the subject matter of authors' rights stems less from the impossibility of finding an objective criterion for this aesthetic element than from the concern of the legislature and the courts to open the protection offered by authors' rights as widely as possible. ${ }^{100}$

There is no doubt that historical examination of the sources of the French revolutionary copyright laws demonstrates conclusively that the popular conception that the French and Anglo-American copyright laws are based on totally different approaches is not valid. As Ginsburg concluded from her study of the matter:

Appreciation of the similarities between the initial French and U.S. literary property régimes may hold significance for modern copyright systems if only because it undermines "historical" assertions of the inherent and original incompatibility of the French and Anglo-American approaches to copyright. There is in fact a rich tradition of copyright congruity upon which modern advocates of international copyright harmonization may draw to formulate mutually acceptable principles for the protection of works of authorship. ${ }^{101}$ 
* In this chapter, the quotations from French texts have been translated by the author except where an English translation of the text has already been published, as is the case, for example, with articles published in the Revue internationale du droit d'auteur (RIDA), which is published in French, English and Spanish. Passages cited from RIDA are taken from the published English version.

Renouard, Ch. A., Traité des droits d'auteur dans la littérature, les sciences et les beaux-arts (Paris, Jules Renouard et Cie. Libraires, 1838), Vol. 1, at 27 .

Pouillet, E., Traité théorique et pratique de la propriété littéraire et artistique (Paris, Marchal et Billard, 3rd ed. 1908), at 6 . Ibid. at 7 .

Dock, M. -C., Etude sur le droit d'auteur (Paris, Librairie générale de droit et de jurisprudence, 1963), at 68 . Pouillet, E., op. cit. at 7; see also Dock, M. -C., op. cit. at 65 . Dock, M. -C., Ibid. at 68 .

Lucas A. and H.-J., Traité de la Propriété littéraire et artistique, Litec, Libraire de la Cour de cassation, Paris, 1994, para. 6.

Dock, M. -C., op. cit. at 82 .

Cited by Pouillet, op. cit. at 9 .

17 The texts of these regulations (les Arrêts du Conseil du Roi) dated 30 August 1777, are published in Renouard, op. Cit. at 167 et seq. For a recent account of developments in France during this period see Hesse, Carla, Enlightenment Epistemology and the Laws of Authorship in Revolutionary France, 1777-1793, 30 Representations (1990) at 109.

Dock, M. -C., op. Cit. at 129.

Decree of 10 August 1790, Article 13; Archives nationales, F 17, 1258, doss. 2 .

21 Decree of 17 March 1791; Collection générale des décrets rendus par l'Assemblée nationale (Paris, 1791).

Hesse, Carla, op. cit., at 117.

3 Ibid. at 118 . 
43 Matthyssens, Jean, Copyright Law Schemes in France during the Last Century, IV RIDA 15 (1954).

44 Commission de la propriété littéraire, collection des procès-verbaux, président le Vicomte de la Rochefoucauld (Paris, Imprimerie de Pillet Ainé, 1826), at 326 .

45 Matthyssens, J., op. cit. at 34.

46 Commission de la propriété littéraire et artistique, Rapports à l'Empereur, Décrets, Collection des procès-verbaux (Paris, Imprimerie Impériale, 1863). 
Ibid. at 252 .

Ibid. at 255 .

Desbois, H., Dalloz, 1957, 1.351.

Rochefoucauld Committee proceedings, supra note 43 , at 32 .

Renouard, op. cit., Vol. I at 435 et seq.

Ibid. at 6 .

Cited by Desbois, Henri in: Le Droit d'auteur en France (Paris, Dalloz, 3rd ed. 1978), at 265.

Ibid.

Pouillet, E., op. cit. at 24 .

Ibid., at 30 .

Cited by Vilbois, Jean in: Historical Account, XIX RIDA 41 (1958).

Travaux préparatoires, Loi no. 57-298 du 11 mars 1957, dossier documentaire, published by Institut de recherche en propriété intellectuelle Henri-Desbois (IRPI), Université Panthéon-Assas (Paris II), at 2 .

Boutet, Marcel, Considérations générales, XIX RIDA 13 (1958).

Speech of M. Jacques Debû-Bridel, Conseil de la République, session of 30 October 1956, Jo 31 October 1956: "In a law such as this, whatever the interests of the authors, which we must defend, whatever the perfectly legitimate interests of producers, which we must respect, the real interested party, not to say the only interested party, is the national community, in other words the public ... we must not forget that our main aim should be to defend the possibility of wider dissemination of works of the mind."

Tournier, Alphonse, An Appraisal of the Law, XIX RIDA 79 (1958).

2 Desbois, Henri, The Moral Right, XIX RIDA 121, 125 (1958); see also Desbois, La loi française du 11 mars 1957, 1957 Le Droit d'auteur $184,185$.

3 There was one exception to the rule that all works recognised by the courts were protected under the new Law. On 13 March 1957, the Civil Court of Paris had found that a producer of sound recordings was entitled to protection with respect to his original recording and that such recordings had to be assimilated in all respects to original literary and artistic works. XVII RIDA 162 (1957).

Pouillet, op. cit. at 140 .

Lang, Jack, 127 RIDA 6 (1986).

Exposé des motifs of the draft law on the rights of authors and the rights of performers, producers of phonograms and videograms and audiovisual communication enterprises, presented to parliament in the name of M. Pierre Mauroy, Prime Minister, by M. Jack Lang. French text in 127 RIDA 168 (1986).

Journal officiel, session of 2 April 1985. 
68 Report by M. Alain Richard in the name of the Commission des lois constitutionelles de la Législation et de l'Administration générale de la République sur le projet de loi relatif aux droits d'auteur et aux droits des artistes-interprètes, des producteurs de phonogrammes et de videogrammes et des entreprises de communication audiovisuelle. See document of the Assemblée nationale no. 2235 (Annex to the minutes of the session of 26 June 1984), 127 RIDA, 176 et seq. $(1986)$.

69 Report of M. Charles Jolibois in the name of the Special Committee of the Senate on the draft Law adopted with amendments by the National Assembly on second reading. Doc. Sénat No. 350. French text in 127 RIDA 278 et seq. (1986).

70 Observations de la commission des Affaires culturelles, familiales et sociales présentées par M. Charles Metzinger, rapporteur pour avis, No. 2235, at 105 .

71 Kerever, A., One Aspect of the Law of $3 \mathrm{July}$ 1985: Modernisation of the Law of 11 March 1957, 127 RIDA 22 (1986).

72 Report of M. Alain Richard in the name of the Commission des lois constitutionelles, de la législation et de l'administration générale de la République on the bill as modified by the Senate, Document No. 2682 of the Assemblée nationale (Annex to the minutes of the session of 15 May 1985), 127 RIDA 255 (1986). See also speech of M. Charles Jolibois in the Journal officiel, Senate session of 3 April 1985, at 104 .

Jolibois report, op. cit. at 282 .

See supra, pp. 115 and 116.

Tournier $A .$, op. cit. at 95.

76 Art. 11 of the Law of 3 July 1985.

77 Art. $41(2)$ of the Law of 11 March 1957.

78 Arts. 31-37 of the Law of 3 July 1985.

79 Supra n. 71 , op. cit. at 181.

80 Law No. 92.597 of 1 July 1992, Official Journal of 3 July 1992, replacing the Laws of 11 March 1957 and 3 July 1985.

81 Lucas, op. cit., paras. 1, 3 and 13.

82 Law No. 94-102 of 5 February 1994 (cf. Articles 335-2 and L. 335-4 Intellectual Property Code).

83 Law No. 94-361 of 10 May 1994 implementing EC Directive No. 91/250 EEC of 14 May 1991 on the legal protection of computer programs.

84 Law No. 95-4 of 3 January 1995 (cf. Articles L. 122-10 to L. 122-13 of the Code; see also Decree in Council of State of 14 April 1995).

85 Renouard, Ch. A., Des droits des auteurs sur les produits de leur intelligence (1838), at 242, and cited in: Ginsburg, Jane C., op. cit. at 169 .

86 Stewart, op. cit. at 374.

87 Escarra, J., Rault, J. \& Hepp, F., La Doctrine française du droit d'auteur (Paris, Editions Bernard Grasset, 1937), at 19. 
88 Desbois, Henri, 1957 Le Droit d'Auteur 185.

89 Lang, J. see supra n. 65.

90 Desbois, Henri, Le droit d'auteur en France, (Paris, Dalloz, 3 rd ed. 1978), at 7 .

91 Kerever, André, Is Copyright an Anacronism?, 1983 Copyright 374.

92 Lucas, op. cit. para. 28.

93 Lucas, Ibid.

94 See Kerever, André, supra n. 31.

95 Ginsburg, Jane C., A Tale of Two Copyrights: Literary Property in Revolutionary France and America, 147 RIDA 131 (1991).

96 Ibid., at 133 .

97 Laligant, Olivier, The French Revolution and Authors' Rights or Perenniality of the Subject Matter for Protection, 147 RIDA 36 (1991).

98 Ibid., at 50 .

99 Plaisant, Robert, La protection du logiciel par le droit d'auteur, 1983 G.P. 2.348 .

100 Laligant, op. cit. at 62.

101 Ginsburg, Jane C., op. cit. at 201. 


\section{Origins of the Law}

As we have seen, the antecedents of copyright in Germany, ${ }^{1}$ as in the other major European countries, are to be found in the system of privileges granted to printers and publishers from the early sixteenth century onwards. Like in other European countries these privileges served to protect printers and afforded no recognition or protection for authors' rights. Progression towards a real copyright system evolved more slowly than in England and France, where in both cases revolution, by overthrowing privileges derived from the crown, gave an impetus to the recognition of authors' rights.

Until the unification of Germany in 1870, the system of privileges and, subsequently, the rights of publishers and authors, was a matter for legislation in various Länder. Privileges thus lived on until the late nineteenth century and were specifically abolished only by the North German Federation Law on Copyright in Writings, Designs and Models, Musical Compositions and Dramatic Works of 11 June 1870. This subsequently became part of the law of the 'Reich' in 1871.

The changeover from privileges to copyright was a slow process, hampered by the fact that the publishers and authors in the many German states had little contact with each other and so were disorganised. First to obtain specific protection in legislation against unauthorised reproduction were the publishers in a Prussian Law of 1794. While this Law was primarily for the benefit of the publisher, the interest of the author was recognised. Although the author was not directly protected, the publisher had to obtain his consent for publication and that consent was only valid for the first edition. Privileges subsisted alongside the publishers' rights. Both privileges and publishers' rights were effective only in the state which granted them. They provided for penal sanctions against pirates, but 
these flourished in Germany in the seventeenth and eighteenth centuries due to the division of the country into so many small states.

Copyright theories as they evolved were based on the concepts and philosophy underlying the German legal system, namely Roman Law and natural law (Naturrecht). "Towards the end of the seventeenth century, the first attempts were made to base the right of the publisher who publishes with the consent of the author on the natural law." ${ }^{3}$

However, in the early eighteenth century the author was still not regarded as having rights in the product of his labour. "Writing was considered a mere vehicle of received ideas which were already in the public domain, and, as such a vehicle, it too, by extension or by analogy, was considered part of the public domain". Recognition of authors' rights as such was not achieved until the nineteenth century. From the mid-eighteenth century onwards, publishers began to offer "honoraria" to authors whose works they printed; these were not real payments, but more in the nature of tokens of esteem or gifts at the discretion of the publisher whose relationship to the author at this period was similar to that of a patron. ${ }^{5}$ On receipt of a flat sum, the work became the property of the publisher.

In the last quarter of the century, a debate took place on the nature of the book and the property rights of publishers and authors. ${ }^{6}$ Fichte, in an essay arguing against the practice of book piracy, distinguished between three distinct properties in the book. When the book is sold, ownership of the physical object passes to the buyer to do with as he pleases. The material aspect, the thoughts and ideas it presents, also pass to the purchaser. However, "the form of these ideas, the way in which, the combination in which, the phrasing and wording in which they are presented" remain the property of the author for ever. ${ }^{7}$ Here, barring the idea of perpetuity expressed by 'for ever', we can recognise the modern concept of copyright. Nevertheless, as already noted, the Prussian Law of 1794 did not recognise any 
rights of authors but reflected the common practice of the time for publishers to obtain the specific consent of authors.

In the early nineteenth century, the idea was conceived that piracy was an attack on the right of personality of the author as opposed to the property right of the publisher. This led in due course of time to the distinction between the so-called moral rights of the author and his economic, property rights in his published works. As the nineteenth century progressed, the concept of intellectual property was advanced in particular by the ideas and writings of leading philosophers like Kant, Hegel and schopenhauer. Kant defended copyright by considering an author's works not as objects the benefit of which should accrue to the author, but rather as extensions of the personality of the author and subject to protection as such.

It was not until the last quarter of the nineteenth century that Germany was finally to do away with privileges, to recognise the rights of the author and to find a solution for the whole territory. As elsewhere, the moving force was the book trade. At the Vienna Congress of 1815, a Committee of the German book trade obtained a commitment in the instrument establishing the Federation of German States to safeguard the rights of authors and publishers against piracy. Legislation remained, however, the responsibility of the Länder.

The first modern copyright law based on the rights of the author was the Prussian Law of 1837 for the protection of works of science and $a r t^{8}$. A major debate took place about the term of protection. Privileges had been granted for longer and longer periods and the publishers' Registry in Leipzig campaigned for protection in perpetuity. Moreover, it was argued that intellectual property should be perpetual like the right to any other property. The legislator, however, according to Ulmer, took account of the interest of the general public and looked to the example of the copyright laws of England and France where duration was limited. Duration was fixed, as a result, at 30 years p.m.a. Other Länder followed the example of Prussia and 30 years became the normal period of protection throughout Germany. 
This period was maintained in the Copyright Act of 1870 and not increased until 1934 when, against substantial opposition, it was increased to 50 years to conform with the Berne Convention. ${ }^{10}$

The influences on the origin of German copyright law were therefore many and various:

It did not grow directly out of the idea of intellectual property but is based on many diverse legal trends. This was reflected in the Acts of 1901 and 1907; the specific rights of the author were enumerated in detail and specific limitations were imposed having regard to conflicting interests.

In this development of the law, the public interest does not appear from the sources to have been a live issue. It may be assumed that it was considered to be in the public interest to protect the book trade against piracy. The authors' rights were conceived as natural rights or rights of personality. Thus, the public interest was not invoked in a positive sense in relation to their protection as it was in England, the United States of America and France. It was not suggested that authors needed rights so as to stimulate creativity or to ensure a supply of books to the general public. The public interest was, however, taken into account in the 1837 Prussian Law in a negative sense when the decision to limit the duration of authors' rights was taken.

The history of copyright theory, case law and legislation in Germany since 1901 has been a steady progression towards an ever-higher level of protection for authors and strengthening of the concept of authors' rights as having their roots in natural law. Its development has also been much influenced by that of the Berne Convention and by the international development of the concept of moral rights, incorporated expressly into German legislation for the first time in 1965.

The primary justification for copyright today in Germany is natural law. It is regarded as an individual, intellectual property right of the author in his work which, in turn, is considered to be an expression of his personality. Schricker points out that, in this respect, the justification for copyright 
law differs from that for patent law: "authors' rights have their justification as individual rights only whereas, in patent law theory, in addition to the individual right aspect, the interests of society in technical progress are also stressed." 12

In considering the development of German copyright law in the twentieth century, it is useful to distinguish between the period before the establishment of the Federal Republic of Germany in 1949 and thereafter. Since then, copyright legislation and case law derive from certain fundamental guarantees in the Basic Law of the Constitution. ${ }^{13}$ The rights of authors are property in the sense of Art. 14 of the Basic Law; in addition, the personal law component of copyright stands on the constitutional guarantees of human dignity and personal freedom found in Arts. 1 and 2 (1) of the Basic Law. The approach to copyright in the late nineteenth and early twentieth centuries would appear to have differed somewhat to that of the post-war period.

\section{Legislative Developments: 1870-1901}

The 1870 Law granted the exclusive right to reproduce a writing by mechanical means to the author (Sec. 1). The publisher was assimilated to the author in the case of collective works. The authors' right was transmissible by contract or will. He had the right to authorise translation and translations were also protected against infringement. There were no moral rights. Legal entities, being publishers of collective works, were assimilated to authors but enjoyed protection for 30 years from publication as opposed to 30 years p.m.a. (Sec. 13). The same protection was afforded to designs and models in the field of geography, topography, natural sciences, architecture, technical arts and other similar fields (Sec. 43), as well as to musical compositions. Public performance rights were recognised. No further privileges were to be granted; those possessing privileges could either maintain their privilege or claim the protection of the law. 
It would appear that the 1870 Law was not adopted without opposition. The arguments of the opponents to the Law were described in 1888 as including: that the protection of literary works was "opposed to the education of the people"; represented "an unjust monopoly"; was a "theft against intellectual well-being" and that the term "intellectual property" was inappropriate. ${ }^{14}$

In the 1880's, Germany was very active in the Conferences which preceded the adoption of the Berne Convention for the Protection of Literary and Artistic Works in 1886. In those discussions, Germany strongly argued against an obligatory period of protection of 50 years and, indeed, continued to do so up to and including the 1928 Rome Conference for the revision of the Berne Convention. Germany also defended the need for exceptions for personal and educational use to be written into the Berne Convention and opposed the efforts of the French to limit these exceptions in the Berlin (1908) and the Rome (1928) Conferences for the revision of the Berne Convention. ${ }^{15}$

In 1876, a Law concerning the right of the author in works of figurative art was adopted. The 1870 Law was replaced in 1901 by the new Act concerning the "Right of the Author in Literary and Musical Works" ${ }^{16}$ which was supplemented by a statute relating to publishing law. ${ }^{17}$ The 1876 Law on the figurative arts was likewise replaced in 1907 by the "Act on Authors' Rights in Artistic Works and Photography". ${ }^{18}$ These two laws reflected the influence of the Berne Convention. The author was defined as the person who had created the work. Legal entities responsible for publishing works, however, were considered to be the author in certain circumstances.

The 1901 Act spelt out the rights granted in detail and the limitations on those rights. Basically, the rights conferred were those of reproduction, translation and public performance. There were many specific exceptions. The author had no right with respect to lending. Reproduction for personal use was permitted provided it was not done for profit. Likewise, public performance 
of musical works was permitted when the performance was not organised for profit and no admission charge was made.

More far-reaching and in due course controversial were exceptions permitting reproduction of published musical works on disc, plate, cylinders, tapes, etc. for the mechanical reproduction of music; moreover, in the case of public performance of musical works accompanied by text, the consent of the author of the text was not required. Duration of protection remained as in the 1870 Law. Proposals to extend protection to 50 years p.m.a. were rejected on the grounds that the number of works still of interest after 30 years was small and that the public interest in obtaining free access to such works outweighed any prejudice that might be caused to a small number of authors. ${ }^{19}$ The 1907 Act extended protection to buildings and works of applied art.

\section{The Twentieth Century}

\section{1-1949}

The development of copyright continued to be influenced by the Berne Convention and its new Acts resulting from the revision Conferences of Berlin (1908) and Rome (1928). The Berlin Act took account of sound recordings and films and this was reflected in an amendment to the law in 1910. The Rome Act incorporated moral rights into the Berne Convention for the first time.

There was to be no further new legislation, however, until 1934, when the period of protection was extended to 50 years in order to conform with the Berne Convention. ${ }^{20}$ Meanwhile, German "case law was able to keep pace with the results of the Rome Conference owing to a liberal interpretation of the texts of the statute." 21 However, work started after the Rome Conference on new legislation. A series of private drafts were put forward at various times throughout the pre-war period. An official draft was published in 1932, representing a joint proposal of the German and Austrian justice ministries. That draft resulted in the Austrian Act of 1936. Another draft was put forward in a 
report of the German Academy of Law in 193922, but further work in Germany was held up as a result of the 1939-1945 Second World War. Work recommenced after the Brussels Revision Conference of the Berne Convention in 1948. Further official drafts were published in 1954, but it was not until 1965 that a new Act was promulgated.

The revision of the 1901 Act was, therefore, under discussion for over thirty years, a time of great changes both in the technology affecting authors' rights and in the development of international copyright.

From 1928 to 1955, Professor Hans Otto de Boor, of Frankfurt University, wrote annual "Letters from Germany" published in 'Le Droit d'Auteur', with only minor interruptions during the war. These provide a fascinating overview of copyright theory and developments in Germany throughout this period. The author has reviewed these accounts to pinpoint the most important developments in case law and to see to what extent the public interest was taken account of as a justification for copyright law, or for its limitation, in copyright theory during that time. After de Boor's death, Professor Eugen Ulmer continued the letters. ${ }^{23}$

In 1926, the Reich Supreme Court ruled on the question of whether the German Act provided protection against unauthorised broadcasting. ${ }^{24}$ According to de Boor, in the opinion of the Court, an opinion shared by exponents of copyright doctrine, the German Act recognised no general intellectual property rights but only protected the author in the exercise of the rights expressly granted to him. Thus, the court could only afford protection against broadcasting if it could be considered an infringement of such a right. The court resolved the issue by deciding that broadcasting could be considered to be a case of professional distribution rather than one of public recital and thus was subject to the authors' control; the definition of distribution was thus extended to embrace broadcasting. The question was debated at the time whether, in the interest of "public intellectual life", broadcasters should be given a compulsory 
licence allowing them to broadcast published works, or works already broadcast with consent, without permission but on payment of equitable remuneration.

In 1928, de Boor also reported on the ongoing dispute between protagonists of the maintenance of a 30-year period of protection, who upheld the interests of the public as against those of the authors' heirs, and those who favoured extending the protection period to 50 years. The leading proponent of the status quo was Professor Ernst Heymann ${ }^{25}$ of Berlin University, whose views on the issue were apparently shared by de Boor. He argued that the period of protection was not envisaged in Germany as a limitation on a presumed perpetual intellectual property right but rather as an additional period prolonging protection after the death of the author out of respect for his personality. Taking the various interests into account, Heymann considered that the interests of the entire German nation should always take priority in matters of copyright. He maintained that the 30-year period had beneficial effects for German intellectual life by promoting wide distribution of works thereafter; in his view, an extension of the term could present grave dangers by withholding works from general use for too long. Heymann also argued that German law, by contrast with French law, was inspired by social factors; it took account of the interest of the community, to which the interest of the individual should conform and even subordinate itself.

By 1930, four draft Acts had been published ${ }^{26}$ and reform of the copyright law continued to preoccupy copyright specialists throughout the 1930s. The major issues on which there was disagreement between the proponents were: the protection of photographs; the nature of the protection to be accorded to films; the question whether legal persons could be considered to be authors; the kind of protection to be accorded to performers and, in later years, producers of phonograms; and, finally, the perennial problem of the period of protection.

Opinion was divided on whether or not legal persons could be authors. This was of particular importance in relation to the 
question of who should be considered the author of a cinematographic work. In the early 1930s, it was proposed that performers should enjoy an author's right but, as the years went by, opinion hardened in favour of their being granted a related or neighbouring right. The question of duration of copyright continued to be controversial. In the four private drafts referred to above, only one proposed increasing the period of protection to 50 years, the others all supporting the retention of the 30-year period. It is of interest to note that two of the drafts proposed giving the author a right to authorise or prohibit commercial rental of a work. Another issue was the need to incorporate moral rights in German legislation following their inclusion in the Rome Act of the Berne Convention. While moral rights were recognised satisfactorily by German case law, they were not specifically protected by legislation.

The official 1932 Joint Proposal of the German and Austrian Justice Ministers proposed that the division of the German Act between literary and musical copyright, on the one hand, and artistic and photographic copyright on the other, should be abandoned. The draft took account of new methods of exploitation of literary and artistic works such as film, radio broadcasting and phonograms. Performers and legal persons were not recognised as being capable of benefiting from a copyright. The draft attempted to define and regulate moral rights. The Government remained undecided about increasing the period of protection from 30 years p.m.a. In these various discussions concerning the revision of the law, the point of view was put forward by some that the legislator should take account of the interests of the public.

The long discussion in Germany on the subject of the duration of protection was finally settled in 1934 when the Government legislated, as noted above, to extend the period of protection to 50 years p.m.a. in order to conform with the Rome Act of the Berne Convention. As Ulmer noted, "this was mainly due to international legal development, behind which Germany could not permanently remain. It may also be noted that this was a Government sponsored bill. From a parliamentary point of view it 
may be assumed that ... the extension could not have been passed at that time." 27

By the late 1930s the proposal had gained ground that a distinction should be made between copyright or authors' rights in the strict sense and other matters. The 1939 draft put forward by the German Academy of Law proposed that the Act should be divided into two main sections: one on authors' rights and a second on related rights which would cover technical designs, maps, photographs, phonograms, broadcasts, performers, etc. In October 1939, Professor de Boor described this draft as representing the completion of an evolutionary process rather than any break of principle with the past. He described the fundamental idea behind the draft as being that the person to be protected was the individual human creator. He drew attention to the fact that, in its origins, the protection of authors and inventors did not aim to protect the creative person. Although natural law had recognised the concept of intellectual property, German copyright law had replaced the system of privileges in the 18th century not by providing protection for the author but by protecting the publisher against counterfeiting. The object of protection in the past had been, therefore, the published work. In the 19th century, the emphasis had shifted to protection of the author with the intention of affording remuneration for the intellectual work of the author by means of an exclusive right. Subsequently, protection had been extended gradually to various new works including, in the 20 th century, films.

The 1939 draft, by contrast, instead of listing and enumerating the various categories of works to be protected included the general formula that all "literary and artistic works" should be protected, provided only that they were individual creations. The author was to be protected in his personal connection with his work by means of moral rights. It followed from these concepts that, in this draft, for the first time, the idea that an author's right could be granted in favour of a legal person was rejected. This applied also in the case of cinematographic works where previously the producer had been considered the author. The draft proposed that ownership of copyright in a film should be 
vested in all those who had made an important artistic contribution to the film. However, the right to distribute the film would belong only to the producer, for practical reasons. As a consequence of this approach, the draft included a separate chapter dealing with related or neighbouring legal domains, establishing protection for other right owners considered to merit the protection of an exclusive right but not an author's right, as such.

While the 1939 draft was not acted upon, an Act of 12 May 1940 extended the protection of photographs from 10 to 25 years. ${ }^{28}$

In 1942, de Boor compared the copyright system in Germany with that in the United States of America which he described as "more formalistic and more industrial" in character. According to him at that time, "for us Europeans the idea of copyright is to protect the creative personality manifested in his work. This idea is not very old. Copyright has developed from the idea of protecting publishers against counterfeiting, that is, from legal notions of an industrial character". However, the German point of view was that "if we wish to protect the creative personality, it is not sufficient to provide him with a financial reward for his work. Rather personal and cultural interests should be put first".

In 1945, de Boor strongly defended the thesis that the film producer should be recognised as the author of the copyright in a film. In his view, it was the only practical solution, without prejudice to moral rights in any pre-existing works.

\section{$1949-1965$}

After the Second World War, in 1951, de Boor described how the ongoing debate concerning the need to revise the copyright law had been enlivened by new inventions such as microphotography and recording machines. The courts were called on to consider whether the making of microfiches of printed editions was permitted under the exception for personal use provided for by Sec. 15(2) of the 1901 Act. Similar considerations arose in relation to the 
recording of broadcasts and phonograms and photographic reproductions of scientific journals.

In the early 1950's, the copyright experts were unanimous that such reproduction constituted a breach of copyright and that the authorisation of the author was required. Proposals were put forward for the granting of licences for such reproduction on payment of a royalty. In this connection, de Boor discussed the theory, with which he concurred, that copyright should be limited for social purposes. The theory in his view allowed for the regulation of relations between the rights of individuals and the public by means of limitations on copyright concerning the period of protection, exceptions for quotation, etc. He stressed, however, that the interests of the public or the collectivity should never be permitted to prevent the author from exercising a right given to him by the law and warned against a tendency to assimilate the public interest with that of a particular industry, for example, the establishments providing microphotographic facilities, who had invoked the public interest in their argument with authors. He pointed out that there are three opposed interests: those of the authors, those of commercial intermediaries (such as the publishers, etc.) and, finally, those of the readers and the general public. The essential task of copyright, he suggested, was to establish an equitable balance between those three groups. All three represented the public or a part thereof. He pointed out that damage caused to the author is as dangerous for the public interest as any prejudice which might affect other groups, and gave as an example of such danger the damage that photocopying and microfiches were causing at the time to scientific reviews.

When after the 1939-1945 Second World War, work resumed on the revision of the copyright law, the Ministry of Justice had in mind to bring the 1901 and 1907 laws up to date and to adapt them to new technology and to the Brussels Act of the Berne Convention. However, according to Ulmer ${ }^{29}$, the authors and their societies were not satisfied with a mere modernisation and argued for a considerable strengthening of their rights. In Ulmer's view, this claim was well-founded since cultural policy was 
backward compared with social policy and the situation of intellectual workers had not been reformed to the same extent as that of other workers. Moreover, the courts in a number of cases strengthened the position of authors with respect to new uses of their works.

In 1954, the Federal supreme Court (Bundesgerichtshof), recognised the existence of a general right of personality grounded in the Basic Law (Grundgesetz) of the Federal Republic of Germany, adopted in $1949 .{ }^{30}$ Article 1 thereof provides for the respect and protection of the dignity of man and Art. 2 for the right of everyone to the free development of his or her personality. The court reasoned that the expression of ideas is an emanation of the personality of the author. This being so, the author has the right to decide if, and in what form, his writings should be distributed to the public. This case was of considerable importance because, previously, only the right of an individual to be named and to authorise use of his own image had been recognised. ${ }^{31}$

In 1953, the District Court (Landgericht) of Frankfurt-am-Main found that the exception for personal use of Sec. 15(2) of the Copyright Act could be applied to photocopying. However, the Court said that that exception should be interpreted in a strict manner and could not be allowed if it would endanger the interests of the author. To the extent that authors' rights were exploited, they should not suffer essential damage and the court considered that regular reproduction could be contrary to the interests of the author. ${ }^{32}$

In 1955, the Federal Supreme Court (Bundesgerichtshof) handed down a landmark decision on a final appeal from the Regional Appeal Court of Frankfurt-am-Main in a case also concerning the interpretation of Sec. 15(2) of the Copyright Act. It decided that the copying of music onto blank, magnetic reel-to-reel tapes was subject to the authorisation of the author and, when sound recordings were copied, also of the producer of phonograms, even where the copy was made for private use. The court thus rejected the notion that copyright protection necessarily had its limit 
in private use. The Court based its decision not on the letter of the law but on its spirit and on general principles of copyright, relying on the fundamental idea of intellectual property. ${ }^{33}$ It stated that the author's control over his work and his right to remuneration for its use by third parties is not granted by the legislator but follows from the nature of things, namely, from his intellectual property which the law recognises but does not create. It followed that the copyright owner had absolute control over his creation in respect of a new method of private reproduction which "by its very nature, could cause a serious economic prejudice to authors if it was not subject to their exclusive rights" .

It is interesting to contrast this decision with that of the Reich Supreme Court in 1927 concerning broadcasting referred to above, where the court took the view that the German law recognised no general intellectual property right. In the meantime, copyright law in Germany had been strengthened by its foundation in the Basic Law of 1949.

A few weeks later, the Federal Supreme Court (Bundesgerichtshof) (4 $^{34}$ gave judgement in a case of photographic reproduction of articles from scientific journals by a firm for the use of its technical personnel. The Court considered such reproduction to be an infringement and not to fall within the exception of Sec. 15(2) of the Copyright Act. A firm, being a legal entity, could not make personal use of a copy; its technical personnel were not using the copies for their personal use but for the benefit of their employer.

In the fifties, two theories were vigorously debated: the authors' societies defended the idea, propounded previously in the nineteenth century, that authors' rights, because they represented intellectual property should be perpetual and give rise once copyright had expired to a perpetual public paying domain. Others, including de Boor and Roeber, contended that an author's right should be considered as a right sui generis emanating from the person of the author and having the dual function of protecting both personal and economic interests. 
Moreover, for them it was a right with social links and, thus, must be limited in time. ${ }^{35}$ Ulmer expressed his view on this debate as follows:

Copyright/authors' rights derive from the great idea of intellectual property which is common to all Europe. Today this idea has its importance ... as, being founded on natural law, it draws attention to the element of equity which is inherent in copyright. No doubt, unlike a material good, a work is not only attributed to the author for the purpose of its economic exploitation, but it is also attached to him as a child of his spirit.... I believe, in particular, that the constitutional guarantee of property applies to copyright. The Basic Law of Bonn guarantees property. In constitutional language, that means that intellectual property is also guaranteed - copyright in its component parts consisting both of patrimonial and moral rights. ${ }^{36}$

\section{The 1965 Act}

The long debate on the revision of the 1901 and 1907 laws finally bore fruit with the new Act on Authors' Rights and Related Rights of 9 September $1965 .{ }^{37}$ This represented a major and comprehensive reform, introducing a clear distinction between authors' rights and related rights ${ }^{38}$ (dealt with respectively in two separate sections of the law) and extending the period of protection for authors from 50 to 70 years p.m.a. At the same time, the law was supplemented by additional legislation on the administration of copyright and related rights providing for state supervision of collecting societies. ${ }^{39}$ It also paved the way for accession, inter alia, to the Brussels Act of the Berne Convention and the ratification of the Rome Convention for the Protection of Performers, Producers of Phonograms and Broadcasting Organisations, 1961.

The new Act, unlike the previous laws, recognised "an al1-embracing concept of literary and scientific and artistic works." 40 The various categories of works are mentioned only as examples so as to permit new types of works resulting from technical development to be protected in future. However, "the demarcation of unprotected works is determined by the axiom that only personal intellectual creations are works within the meaning of the law." ${ }^{11}$ The author is the person who is the creator of the work. Only natural persons are concerned and the law did away with the previous situation where in certain cases legal 
entities, including film producers, were regarded as authors. ${ }^{42}$ Previous drafts had proposed an exception to this rule in favour of film producers but the solution adopted was to provide a legal presumption of cession from the authors to the producers of all rights required for the exploitation of the film. In contrast to many other legislations, in Germany copyright belongs also to employees who create a work in the course of their employment.

The Act divides authors' rights into moral rights, exploitation rights and other rights.

Moral rights are defined so as to protect the author with respect to his intellectual and personal relations to the work. These provisions consolidate the all-embracing protection of the moral rights of the authors developed over the years by case law. Unlike French and Italian moral rights, the moral right in Germany is not a perpetual right and expires at the same time as economic rights.

The author was also granted a right of dissemination in the sense of first communication, which Ulmer described "as a fundamental right of the author, depending as well from the moral right as from exploitation rights". ${ }^{43}$ The provisions concerning rights of exploitation aimed to include all forms of reproducing and communicating a work which technical progress had made or might in the future make possible in original form and in any adaptation thereof. Thus, the author is afforded a comprehensive right to communicate the work to the public in immaterial, that is, unfixed form. Two new rights were introduced: the artists' resale right and a right of the author to equitable remuneration in the case of lending for profit. Non-profit making libraries, especially public libraries, were exempt. ${ }^{44}$

The limits imposed on the rights of authors and other right owners in the Act, representing the dividing line between the interests of right owners and those of the public, were described as follows by Ulmer: works. This granting is subject to certain limitations which are 
important from the practical standpoint: the needs of cultural life are served by freedom of quotation and borrowing. In the interests of public information, limits are placed on copyright in favour of press, radio and film reporting. ${ }^{45}$

The exceptions permitted by the new law in fact drew the line in a much more favourable position for the author than had the previous law. As regards reproduction for personal use, the law implemented case law by providing for royalties to be paid for private copying and included detailed regulations concerning reprography. The previous legal licence in favour of broadcasting was removed and that in favour of the phonographic industry was converted into a compulsory licence which may only be exercised if the so-called mechanical rights of the author (rights to authorise the reproduction of works in sound recordings) are not administered by a collecting society.

The extension of the term of protection to 70 years had not been proposed in the Government Bill. In the past, there had been great resistance to the adoption of a 50-year term, Germany having defended retaining 30 years for nearly 100 years. opponents of change had upheld the interests of the public against the interests of the authors' heirs. The 1965 decision was taken in the context that the Bill put forward by the Government had proposed a public paying domain (Urhebernachfolgevergütung) with the object of caring for the needs of authors and their dependants. That proposal was rejected mainly because the choice of authors meriting assistance could have involved the danger of a state-controlled culture. However, the 70-year protection period was adopted by Parliament as a compromise. The decision was not expected:

The wider public had not discussed the question. Nor did the plenary meeting of the Bundestag discuss either the pros or the cons. After the experience of the twenties this was surprising and showed a marked change in the emphasis on values. The interests of the public, which formerly had found such eloquent defenders, no longer seemed of such weight as to hold the scale against those of heirs of authors. ${ }^{46}$

Related or so-called neighbouring rights were introduced and regulated in detail by the law for the first time. Related rights in Germany concern not only the rights of performers, producers of phonograms and broadcasting organisations but also of film 
producers and rights in certain editions. The inclusion of related rights and the distinction drawn between the rights of authors and the beneficiaries of related rights reflected the fact that: "from the 1920s onwards German case law had been concerned to define with particular clarity the difference between creation and performance, and consequently between copyright and related rights (Leistungschutzrechte). "47

The legislator took over the distinction and, as Ulmer pointed out, the rights "are of special design and in general ... are inferior to copyright in both content and duration". ${ }^{48}$

The 1965 Act was in its time considered by many to be the most up-to-date in the world. Kreile has described it as having:

not only confirmed comprehensive moral rights for authors, but also aimed to shape the pecuniary powers of the author to such an extent that if possible every type of use of the work is subject to his or her control. Furthermore, the law aimed to make it clear that authors can make every use of their work subject to the payment of a fee. ${ }^{49}$

The Act was also considered to set new standards in its creation of specific related rights for phonogram and film producers and performing artists (with a period of protection of 25 years). Extension of the period of protection for authors to 70 years also set a new standard.

\section{The Public Interest and Article 14 of the Basic Law}

As has already been pointed out, the development of copyright legislation and case law since 1949 has been influenced by the Basic Law of the Federal Republic of Germany adopted in that year. It is important to note that the Basic Law not only guarantees the economic rights of authors under Art. 14 and their moral right under the rules on the protection of the personality (Arts. 1 and 2) but it also lays down certain rules as regards the public interest.

Article 14 of the Basic Law, concerning property, right of inheritance and expropriation, reads as follows: 
(i) Property and the right of inheritance are guaranteed. Their content and limits shall be determined by the laws.

(ii) Property imposes duties. Its use should also serve the public interest.

(iii) Expropriation shall be permitted only in the public interest. It may be effected only by or pursuant to a law which shall provide for the nature and extent of the compensation. Such compensation shall be determined by establishing an equitable balance between the public interest and the interests of those affected. In case of dispute regarding the amount of compensation, recourse may be had to the ordinary courts.

In a series of cases the German Federal Constitutional Court (Bundesverfassungsgericht) has clarified the impact of the Basic Law on copyright law and, in particular, the relationship between copyright and the public interest; the issue has arisen with respect to the extent to which the "limitations upon copyright" provided for by the Copyright Act "are justifiable in the public interest". The Court has also defined the role of the legislature under Art. 14(1), sentence 2, of the Basic Law with specific reference to copyright.

The constitutional validity of the 1901 and 1907 Acts could only be contested up to 1 April 1952, pursuant to Art. 93 of the Law Establishing the Federal Constitutional Court. All the cases, therefore, in which the court has examined the relationship between the Basic Law and copyright law postdate the 1965 Copyright Act. Subsequent amendments to that Act, in 1972 and 1985, were due, in large measure, to the need to implement certain decisions of the court.

Due to the fact that actions contesting the constitutional validity of newly-enacted legislation ${ }^{50}$ must be brought within a year, several cases were filed immediately after the adoption of the 1965 Act, with the result that the court delivered five copyright decisions in July 1971. The cases covered the constitutional validity of the following provisions of the 1965 Act : 
Sec. 27(1) exemption of public libraries from the payment of royalties;

Sec. 46 exemption from payment of remuneration in the case of collections for religious, school and instructional use;

Sec. 47 no payment of remuneration for the recording of school broadcasts;

Sec. 53(5) obligation for manufacturers of tape recorders to pay remuneration with respect to private copying of sound recordings;

Sec. 135 transformation of the formerly recognised copyright of performers in phonograms into a related right with a shorter protection period. ${ }^{51}$

The Court linked its decisions in these cases by express references and laid down its views on the relationship between the Copyright Act and the Basic Law in a detailed discussion in its judgement on the Sec. 46 case, known as the "school book case". In this study, the judgements are not analysed in all their detail but with special regard to the issue of the relationship between copyright and the public interest.

In the school book case, ${ }^{52}$ the court found:

(a) Copyright as a right of exploitation constitutes "property" within the meaning of Art. 14(1), sentence 1, of the Basic Law;

(b) Art. 14(1), sentence 1, of the Basic Law in principle guarantees the attribution of the economic value of a copyrighted work to the author. It does not, however, provide a constitutional safeguard for any and all kinds of exploitation. It is for the legislature to establish, in the course of determining the contents and limits of authors' rights through the substantive regulation of the copyright law, appropriate standards which guarantee an exploitation of these rights that is commensurate with the nature and social importance of copyright (Art. 14(1), sentence 2, of the Basic Law). 
(c) The interest of the general public in free access to things of cultural value justifies the incorporation, without the author's consent, of published protected works into collections which are intended for religious, school or instructional use, but not, however, that the author must make his work available free of charge (Sec. 46, Copyright Act).

In its judgement, the court identified a number of considerations relevant to the public interest in connection with the definition of the role of the legislator in determining the content and limits of property.

Having confirmed that the economic rights of authors are to be considered property in the sense of Art. 14 of the Basic Law, the court considered the extent to which the legislator could impose limitations on those rights and held:

Since there is no preexisting and absolute definition of property and since the content and function of property are capable and in need of adapting to social and economic situations, the Basic Law has put the legislature in charge of defining the scope and limits of property (Art. 14(1), sentence 2, of the Constitution). This applies also for the economic rights of the author, which, just as tangible property rights, need shaping by the legal order. The legislature, however, being bound by the Basic Law may not deal with this at random. In defining the privileges and duties that make up the content of this right, it must preserve the fundamental substance of the property guarantee while at the same time also keeping in line with the other constitutional provisions. Only to this extent is the copyright protected under the Basic Law.... This attribution in principle of economic rights to the author for his free disposal does not mean, however, that thereby every conceivable way of exploitation is constitutionally secured.... It is for the legislature to establish in detail, in the course of determining the content of copyright ... adequate standards which guarantee an appropriate exploitation and a utilisation that corresponds to the nature and the social meaning of the right....

In assessing the constitutional validity of a statutory limitation on authors' rights it is necessary to take into account:

that the legislature is not only obliged to secure the interests of the individual; rather, it is also charged with drawing bounds on the individual rights and powers that are necessary in the interest of the general public; it must bring about a just balance between the sphere of the individual and the interests of the public. Thus, the constitutionality of the contested provision ... hinges upon its justification by the public interest. 
Applying this principle to the case in question, the court found that the general public "had a substantial interest in seeing that its young people, in the course of an up-to-date education, become acquainted with intellectual creations.... The realisation of this social task would not be guaranteed," if the author could prohibit the inclusion of his work into a collection. However, it decided that, while the public interest demanded that the author could not prevent the use of his work in this case, he was entitled to be paid remuneration.

Under the property guarantee the author has in principle the right to be attributed the economic value of his work to the extent that the interests of the general public do not have priority over the author's affairs ... the general public's interest, as such, in an uninhibited access to copyrighted works is not sufficient. In view of the intensity of the limitation on the copyright owner's position, there must be an increased public interest in order to justify such a regulation under the Constitution.

In the Sec. 47 (school broadcasts) case, the court found that there was a public interest in making it possible that school broadcasts can be presented to the intended audiences at the right moment, and, therefore, in allowing schools to record works included in a broadcast. Since authors are remunerated in respect of the original broadcast, an additional remuneration for the recording (which in any case has to be destroyed in due course) is not necessary.

Again, applying the criteria laid down in the school books case, the Court decided, in the Sec. 27 (exemption of public libraries from payment of royalties) case, that the property guarantee of the Basic Law does not force the legislature to secure for the author all the means of economic exploitation imaginable. Section 27 granted authors a right to remuneration if copies of a work were lent and the lending was executed for the financial gain of the lender. This meant that public libraries of all kinds were exempt from payment. The Court ruled that the Basic Law did not oblige the legislator to guarantee remuneration to the author in every case of lending and that the differentiation in the law between profit-making libraries and public libraries was permissible. In this case, the public benefit from the limitation on the authors' rights is evident. 
In judging the constitutional validity of Sec. 135 (conversion of performers' copyright into a related right), the court held that Art. $14(1)$ of the Basic Law cannot be "an insurmountable barrier for the legislature when reforms prove necessary. "Thus, it is legitimate to reshape individual rights if it is in the public interest and does not constitute an undue burden. However, as regards the reduction of the term of protection for existing phonograms, resulting from a change in the time when the period of protection began, the court held it could not be reconciled with the property guarantee of Art. 14(1).

These issues were considered once again by the Federal Constitutional Court in the Church Music case in $1978^{53}$ when the constitutional validity of Sec. 52 of the Copyright Act, which permitted free and unauthorised use of musical works in churches, was the subject of examination. The Court held that, whereas the provision allowing the performance without authorisation was in accord with the Constitution, the exclusion of remuneration in the case of church events was unconstitutional and incompatible with the guarantee of property in Art. 14 of the Basic Law. The Court observed that "this guarantee of the Basic Law gives the author the economic right to use this intellectual property... The legislature is, in principle, required to attribute the economic control of the creative work to the author and to allow him the freedom to dispose of it at his own responsibility."

In its judgement, the Court emphasised the concept of the social obligation of intellectual property. It defined this concept by stating that no disproportionate reduction of the rights of individuals can be tolerated. For the public interest to prevail over the interests of the individual, that interest must be sufficiently important to override the right to remuneration. It held, inter alia:

Legislation moreover has the task of taking the interests of the general public into consideration. Yet the power of legislative provision is not unlimited. Any restrictions on the right of use that are made in the public interest must therefore be supported by legitimate grounds. An excessive restriction that is not dictated by the social demands on copyright cannot be justified by Art. 14(2) of the Basic Law.... As the right of use belonging to the author ... is the result of his own personal effort and not of an unearned property 
right accruing to him, he may not be denied his right to compensation on the basis of any consideration relating to the public good.

Within the framework of Art. 14 of the Basic Law, therefore, the question of the public interest arises in a negative sense as the basis for possible restrictions upon the property rights of authors. The basic rule as regards property in the result of intellectual creation is to give exclusive rights to the author. These rights may be reduced to a right to equitable remuneration if there is a social or public interest in restricting the exclusive right and even expropriated altogether if the public interest in free access to the work is considered of overriding importance.

The Court has established a concept of "proportionality" or "balancing of interests" to reconcile the interests of property owners, including right owners and the public. In each case, the question arises whether, taking the principle of proportionality into account, the "intellectual public interest" is more important than the right of the author. If so, it is justified for the payment of remuneration to be excluded altogether.

\section{Subsequent Amendments to the 1965 Act}

\section{The 1972 Amendment}

As mentioned above, the Federal Constitutional Court handed down its decisions in the five landmark cases already discussed in July 1971. These decisions prompted certain provisions of the 1972 Amendment to the 1965 Copyright Act: Sec. 27 (concerning library royalties), Sec. 46 (concerning textbook royalties) and Sec. 135 (period of protection for performers). The share of the artists' claim with respect to his resale right (droit de suite) was also increased (Sec. 26).

The Federal Constitutional Court had held that the exemption of public libraries from the so-called library royalty was not contrary to the Basic Law. The Government, however, in its 1972 Amendment, extended the obligation to pay royalties in all cases 
of rental or lending to "an institution accessible to the public (library, record library, or other collection)," whether public or private. As regards textbooks, the court had declared that the exemption from paying remuneration to authors in respect of their works included in collections for religious, school and instructional use was unconstitutional. The amendment to sec. 46 made it clear that the author should be paid an equitable remuneration for the reproduction and distribution of his works in such collections. The amendment to Sec. 135 took account of the Federal Constitutional Court's decision that the provision was unconstitutional to the extent that the shorter term of 25 years accorded to producers of phonograms and performers under the 1965 Act was retroactive and applied to phonograms made before 1 January 1966. The amendment provided that such phonograms should remain protected for 25 years from 1 January 1966 unless the protection period applying to them would have expired earlier under the old law. 'In the latter case," the previous protection period applied.

\section{The Amendment Act 1985}

A further significant reform took place in 1985 with the adoption of the Act Amending Provisions in the Field of Copyright of 24 June $1985 .{ }^{54}$

As Margret Möller has pointed out: "The central feature of the Amendment Act is its provision for the obligation to pay remuneration for the reproduction of copyright works for private and other personal uses." 55

The amendments relate to Sec. 53, which lays down the conditions under which copies may be made without the authors' consent, and Sec. 54, which specifies what is to be paid, and by whom, for such reproduction. Both private copying of sound and audiovisual recordings and reprography are affected. The levy on recording equipment which was first introduced in 1965 was extended also to blank recording media. ${ }^{56}$ With regard to reprography, the author is entitled to be paid equitable remuneration by the manufacturer or importer of photocopying appliances. In addition, where such 
appliances are operated in educational and research institutions, public libraries, etc., the operators of the appliances must pay. In each case, the rates of remuneration are laid down in the Act, giving rise to the risk of the amounts being devalued through inflation. For that reason, Parliament (the Bundestag), when voting on the $1985 \mathrm{Act}$, invited the Federal Government to submit a report every three years following its entry into force on "the development of copyright remuneration under sec. 54 of the Copyright Act taking into particular account whether the proceeds of remuneration are held equitable within the meaning of Sec. 54 of the Copyright Act", together with a report on the "impact of technical developments on copyright and related rights and where necessary to propose suitable measures to safeguard the economic substance of intellectual property".

The Bundestag in the same resolution invited the Government to conduct a study on the economic significance of copyright which has subsequently been carried out and the results published by the Institute for Economic Research (IFO) in Munich. ${ }^{57}$ Dietz remarks that the invitation of the Bundestag to study these and other issues of lesser significance bears

witness to the awareness of the Bundestag that an up-to-date copyright law is in need of continuous improvement and supplementing.... Only a well-devised ruling, striking an intelligent balance between the interests involved..., can provide effective protection for authors and for their successors in title, as for the owners of neighbouring rights, not only as regards the legal aspect but also from an economic point of view. ${ }^{58}$

A number of other reforms were introduced in 1985. Protection for computer programs as literary works was introduced confirming a principle already recognised by the Courts (Sec. 2(1)). A general obligation to pay remuneration for public communication of copyright works, even in cases where the communication takes place free of charge, serves no gainful purpose of the organiser and where the performers receive no fee, was introduced as a result of the Federal Constitutional Court's decision in the Church Music case. This principle is subject to only a few specified exceptions. 
The term of protection afforded to photographs was modified and a distinction made between three kinds of photographs on the ground of different levels of creativity. "Photographic works" enjoy protection for 70 years p.m.a.; "documentary photographs" 50 years from publication or, if unpublished, from making; and "all other photographs" 25 years from publication or making.

Criminal sanctions against piracy were reinforced to tackle what was seen as an increasing problem. The penalty for unlawful exploitation on a commercial basis was increased to imprisonment for up to five years or a fine. Public prosecution in cases of piracy was also provided for as a general rule. Previously, offenders had to be prosecuted by means of a private complaint except in cases where the public prosecutor found public prosecution to be in the public interest. A number of amendments were also introduced to the Copyright Administration Act.

\section{Follow-up to the 1985 Act}

As mentioned above, at the time of the passage of the 1985 Amendment Act, the Bundestag instructed the Government to report every three years on developments regarding: (i) the remuneration payable to right owners pursuant to Sec. 54 of the Act; (ii) the effects of technological developments on copyright and related rights; and (iii) to make proposals for suitable measures to protect intellectual property with particular regard to its economic aspects.

The Bundestag had also called for studies on the importance of copyright for the national economy and certain other matters.

In July 1989, therefore, the Government presented a report to the Bundestag which was passed in September of that year to the Legal Affairs Committee for consideration. The Government in its report took account of the economic study into the importance of copyright for the national economy which had been completed in the meantime. 
The economic study concluded that works which qualify for copyright protection account, directly and indirectly, for about DM 54 billion in income and roughly 799,000 jobs $13.1 \%$ of the population in gainful employment), and contribute $2.9 \%$ to the generation of domestic income. If computer software had been included - following the method of studies in other countries a contribution of $3.3 \%$ to the domestic generation of income would have resulted. The report also concluded that "the development in West German copyright industries has been more dynamic than for the economy as a whole.... Thus, the economic importance of copyright industries with respect to the generation of income and jobs deserves to receive special attention."

It concluded, further, that "it must be emphasised that a decisive precondition for this is appropriate copyright legislation, also with respect to the approaching single European market. " 59

The Government's report analysed four topics. Chapter 1 dealt with the development of the fees payable for private copying and reprography under Sec. 54 of the Act. Chapter 2 discussed the impact of technical developments on copyright and related rights, dealing in particular with the following issues: the impact of digital recording techniques; rental of sound recordings and videos; the term of protection to be afforded to sound recordings and performers; and, in the light of initiatives of the European Commission, cable distribution of TV broadcasts and the protection of computer programs and data bases. Chapters 3 and 4 address respectively the question whether sound engineers should enjoy a related right and legislation on copyright contracts. This is not the place for a detailed consideration of the Government's proposals. ${ }^{60}$

The Legal Affairs Committee of the Parliament in late 1989 called for a draft Act to be prepared incorporating the Government's proposals. Although it was clear that a comprehensive reform of the law could not be achieved during the legislative period, the Committee considered two matters to be so urgent that they should be dealt with straight away. They called for the extension of the 
term of protection for performers from 25 to 50 years and the improvement of the right to information under sec. 54 of the Copyright Act to facilitate the collection of levies for private copying and reprography.

These amendments were incorporated into the Law to Reinforce the Protection of Intellectual Property and to Combat the Piracy of Products, which entered into force on 1 July 1990 and is known as the "Product Piracy Act".

The right to receive information in connection with the collection of fees arises now with the claim for payment (instead of as previously with respect only to the previous calendar year). If the person obliged to provide the information fails to do so, double fees may be charged.

An array of effective provisions was also introduced in the Act for the pursuit and punishment of infringers of copyright and related rights. Penal sanctions were increased (commercial piracy being made punishable by up to five years' imprisonment or fine), civil and criminal possibilities for destruction and seizure of infringing goods extended, discovery procedures improved and, finally, the possibilities for customs authorities to intervene in product piracy cases improved.

\section{Recent Developments}

Several further pieces of legislation on copyright deserve mention, the most recent of these having been necessary to comply with EC Directives in the field of copyright and related rights. First, the Treaty of Union of 31 August $1990,{ }^{61}$ which effected the reunification of Germany, included a number of provisions on industrial and intellectual property. As a result, in the case of copyright, the law of the Federal Republic of Germany (i.e. the Copyright Act of 9 september 1965, as amended) has applied in the territory of the former German Democratic Republic since unification took effect on 3 October 1990. 
A second $\operatorname{law}^{62}$ to amend the Copyright Act 1965, dated 9 June 1993, had the purpose of bringing German law into line with the EC Directive on the legal protection of computer programs of 14 May $1991 .^{63}$

The provisions of the Directive were incorporated literally into the German law, resulting in one important change to the standard of protection in relation to computer programs. The Directive provides for a lower standard of originality than the previous German law, which required computer programs to be of a level of creativity considerably surpassing the average to qualify for protection as literary works. ${ }^{64}$ To conform with the criteria of originality in the Directive, the law now provides that computer progams shall be protected if they constitute original works in the sense that they are the result of their author's own intellectual creation. No other criteria, particularly of a qualitative or aesthetic nature, shall be applied to determine their eligibility for protection (emphasis added).

The Third Law Amending the Copyright Law of 23 June $1995^{65}$ implemented both the 1992 EC Directive on Rental Right and Lending Right and on Certain Rights Related to Copyright in the Field of Intellectual Property and the 1993 Directive Harmonising the Term of Protection of Copyright and Certain Related Rights. ${ }^{66}$ To comply with the former, amendments were necessary to introduce a distribution right and rental rights into the German law and to limit the previous law on exhaustion of rights so that rental rights will continue to subsist after first sale. Further amendments were needed to bring the law into conformity with the Directive as regards certain related rights of performers, producers of films and phonograms and broadcasting organisations.

As regards the term Directive, although the 70-year term of protection for literary and artistic works was already provided for under the German law, amendments were necessary to increase the period of protection for film and phonogram producers and broadcasting organisations from 25 to 50 years after publication or, if unpublished, 50 years after the production, bringing the term of protection for these right owners to the same as that for 
performers. The law has also been changed to provide for nationals of other Member States of the European Union to receive equal treatment under the Copyright Law to bring the law into conformity with the decision of the European Court in the Phil Collins case. ${ }^{67}$ The law has further been amended with respect to photographs to bring it into line with the Directive, which provides that photographs are to be considered original in the sense that they are the author's own intellectual creation; no other criteria such as merit or purpose are to be applied to determine their eligibility for protection. ${ }^{68}$ This necessitated a change to the German law, which previously distinguished between photographic works, documentary and other photographs, giving them different terms of protection. Thus, in future there will be two categories of photographs, photographic works protected for 70 years p.m.a. and all other photographs (not being the author's intellectual creation) will be protected for 50 years from publication.

Further legislation to amend the law to comply with the Directives on Satellite and Cable Distribution (1993) and on the Protection of Databases (1996) can be expected in due course. ${ }^{69}$

\section{Conclusion}

In German copyright law theory, the rights of authors are considered to derive from natural law. The legislation merely recognises and develops these rights, which may only be limited to the extent required by the social obligations of the author to the general public. It is as a result of this latter concept that it may be affirmed that the public interest has, throughout the development of modern copyright law, been taken into account as an important factor for consideration in setting limits to the exclusive rights of copyright owners. It has always been an important factor in determining the term of protection and, indeed, the reason why it took Germany until 1934 to extend the term to fifty years p.m.a. was because such an extension was considered to be against the public interest and of only marginal potential benefit to authors. 
As the case law of the Constitutional Court has shown, the issue of the balance between the interests of right owners and those of the public has gained in importance in the years since the adoption of the 1965 Copyright Act. The fact that this has led to the introduction of a whole series of compulsory licences, substituting remuneration for the exclusive right of the author has been criticised. For example, Nordemann ${ }^{70}$ has called for a return to an unrestricted exclusive right of the author on the ground that compulsory licences have led to an unjustified advancement of users' interests. According to him, under

the old German copyright law, there were clear lines of demarcation marking the borderline between the interests of the author and those of the public at large. Either the author had an exclusive copyright or third parties had the right to make free use of his work. The single exception, the compulsory licence for phonograms ... did not really spoil the purity of the system.

It is apparent, moreover, that by contrast with the development of copyright law in the UK and the USA, the public interest has not been considered in Germany as a factor to be taken into account in a positive way in relation to copyright. The concept that an effective system of copyright protection is of itself in the public interest because it has social benefits, stimulating creativity by providing a just reward for labour and encouraging people to write, compose, etc., thus benefitting the community, is not put forward as a justification for copyright. As we have seen, the primary justification for copyright is considered to be natural law.

Recently, however, it is apparent that the Bundestag has become aware of the importance of copyright for the national economy and it is significant that the 1989 IFO study concluded that appropriate copyright legislation is a precondition for a further increase in the weight of copyright industries with regard to more income and jobs. Here the German experience would appear to be moving towards the concept of copyright as a stimulus to creativity.

Moreover, Schricker ${ }^{71}$ notes that, taking account of the economic, social and cultural aspects of copyright, it may well be that 
there will be a demand in the future for the German legislator to take account of the public interest in a positive way. While emphasising the fundamental importance of copyright for intellectual creativity and for cultural life, he draws attention to its economic impact and to the fact that publishers, film producers and other cultural industries depend on the copyright system. He suggests that legislative policy should take account of the economic function of copyright by providing adequate protection for protected works in the market place so as to provide a sufficient return to authors and other right owners and to ensure that the copyright system promotes cultural production.

In his view, ${ }^{72}$ therefore, the objective of the copyright legislator should be to formulate the law in such a way that it will make a positive contribution to intellectual, cultural and economic progress. He accepts the view that an efficiently organised system of copyright protection providing adequate financial rewards to the author can provide a framework for optimal creative production and encourage the dissemination of works. He suggests that an acceptance of this point of view and taking into account of economic considerations would not necessarily lead to the underlying principle of natural law being disregarded. Rather, copyright law could find an additional justification in the idea that it stimulates creativity. This could strengthen the case for protection beyond the minimum standards guaranteed by the Basic Law. He suggests also that this justification could provide grounds for ensuring that the interests of industries which act as intermediaries between the author and the public are adequately protected. The Constitutional Court has declared it the task of the legislator to determine the social function of the rights guaranteed by the Basic Law. This could be understood not only as requiring the legislator to set limits to those rights but also to stimulate the development of copyright in a way that takes account of the public interest. 
In this study Germany means historical Germany up to 1949, thereafter the Federal Republic of Germany and, from 1990, reunited Germany. Copyright developments in the GDR during the post-war period until the reunification of Germany in 1990 are not covered.

The following definition of natural law is quoted in the oxford Companion to Law by David M. Walker (Oxford, 1980):

"In general, it denotes belief in a system of right or justice common to all men prescribed by the supreme controlling force in the universe and distinct from positive law, law laid down by any particular state or other human organization. The starting points of all natural law thinking have been 'reason' and 'the nature of man'."

Stewart, Stephen M., International Copyright and Neighbouring Rights (Butterworths, 1983), para. 2.06.

4 Woodmansee, Martha, The Genius and the Copyright: Economic and Legal Conditions of the Emergence of the Author, 17 Eighteenth Century Studies (1984) 425 at 434 .

Ibid. at 435 .

$6 \quad$ Ibid., 440 et seq.

7 Fichte, Johan Gottlieb, Proof of the Illegality of Reprinting, 225228 .

$8 \quad$ See p. 247 of this study for original text.

9 Ulmer, Eugen, Urheber-und Verlagsrecht (Berlin, Heidelberg, New York, Springer-Verlag, 1980), at 54 .

10 It is ironical that Germany, which for so long opposed any increase in the term of protection on grounds of the public interest should have been the driving force 60 years later behind the increase in term to 70 years p.m.a. throughout the European Union, and possibly as a direct result in the future, in the Berne Convention and the United States of America.

11 Ulmer, op. cit., at 55. On the history of German copyright law see especially Vogel, Martin, Deutsche Urheber und Verlagsrechtsgeschichte zwischen 1450 und 1850 (Frankfurt a. M., 1978); Die Geschichte des Urheberrechts im Kaiserreich, 12 GRUR (1987) at 873; Urheberrecht in Deutschland zwischen Aufklärung und Vormärz, Beilage zum Bbl. Nr. 77 Buchhandelsgeschichte (1989) at 96; Urheberpersönlichkeitsrecht und Verlagsrecht im letzten Drittel des 19. Jahrhunderts, 8/9 GRUR (1994) 587; Schricker, Gerhard, Hundert Jahre Urheberrechtsentwicklung, in Festschrift zum hundertjährigen Bestehen der Deutschen Vereinigung für gewerblichen Rechtschutz und Urheberrecht und ihrer Zeitschrift, $\mathrm{VCH}$ Verlagsgesellschaft mbH, Weinheim (1991) Part 4, at 1095.

12 Schricker, G., Urheberrecht, Kommentar (Munich, Beck Verlag, 1987), at 59 .

13 Grundgesetz (Basic Law) of the Federal Republic of Germany (FRG) of 23 May 1949, I Federal Law Gazette (Bundesgesetzblatt - BGBI. 1), 23 May 1949.

14 Fleischmann, Unsere Zeit, No. 10 1888, quoted in: 1888 Droit d'Auteur 113 . 
1908 Berlin Act (entry into force 9 September 1910) and 1928 Rome Act (entry into force 1 August 1931).

of 19 June 1901 (RGBI. S. 227).

Also of 19 June 1901 (RGBl. S. 217).

of 9 January 1907 (RGBl. S. 7).

See explanatory memorandum (Begründung) attached to the draft of the Act - presented to the Reichstag on 8 December 1900, Doc. No. 97, 10th legislative period, II Session 1900/1901, at 34. See also the Report of the Parliamentary Commission on the Report, Doc. No. 214, at $61-62$.

Act Relating to the Prolongation of the Period of Protection of Authors' Rights, 13 December 1934, Reichsgesetzblatt II Partie, No. 61, 19 December 1934, at 1395.

Ulmer \& Rauscher auf Weeg in: Stewart, op. cit. at 415.

GRUR 1939 at 242 .

From 1972 until 'Le Droit d'Auteur' and its English language version 'Copyright' ceased publication in December 1994, the task of writing regular reports on German copyright developments fell to Adolf Dietz. Due to her limited knowledge of the German language, the author has relied heavily on these accounts of German law and theory. Prior to 1960, Le Droit d'Auteur was published in French only. Quotations therefrom, therefore, are the author's translations.

RGZ 113 S. 413

Heymann, Ernst, Die Zeitliche Begrenzung des Urheberrechts (Berlin, Prussian Academy of Sciences, 1927).

By Messrs. Goldbaum/Wolf (UFITA 2 (1929) 185), Elster (UFITA 2 (1929) 652), Hoffmann, (UFITA 2 (1929) 659), and Marwitz (UFITA 2 (1929) 668).

Ulmer, E., 1965 Copyright 282.

Act of 12 May 1940, Reichsgesetzblatt I, at 758.

Ulmer, E., Lettre d'Allemagne, 1956 Le Droit d'Auteur 180, 182.

Grundgesetz (Basic Law) of the Federal Republic of Germany (see supra note 7).

1 Decision of the German Federal Supreme Court, 26 November 1954, 15 BGHZ 249. For a full account of the case see de Boor, Lettre d'Allemagne, 1955 Le Droit d'auteur 180.

32 Decision of 11 June 1953, cf. De Boor, Le Droit d'Auteur, April 1994, at 74 .

3 Decision of the German Federal Supreme Court, 18 May 1955, 17 BGHz 266.

Decision of the German Federal Supreme Court, 24 June 1955, 18 BGHZ 44 . 
De Boor, Lettre d'Allemagne, 1955 Le Droit d'Auteur 206; Roeber, G., Urheberrecht oder Geistiges Eigentum, 21 UFITA 150 (1956).

Ulmer, E., Lettre d'Allemagne, 1957 Le Droit d'auteur 16 (author's translation).

37 Act on Copyright and Related Rights of 9 September 1965 (Gesetz über Urheberrecht und verwandte Schutzrechte (Urheberrechtsgesetz)). It entered into force on 1 January 1966.

Prior to the 1965 Act, the protection of performers and producers of phonograms was governed by the Act concerning Copyright in Literary and Musical Works, of 19 June 1901, as amended in 1910, and the Act extending the terms of copyright protection of 13 December 1934. Section 2, para. 2 of the Act, as amended in 1910, assimilated the recording of literary and musical works to adaptations of those works. According to Ulmer (1961 Le Droit d'auteur 14), the intention of the legislator in including this provision was to protect the record producer against unauthorised reproduction. The legislator started from the premise that the contribution of the performer was similar to an adaptation of a work because of its personal character. Thus, the performer was designated as the beneficiary of the right, the producer being obliged to acquire any rights of his own contractually from the performer. The right of the performer was assimilated, therefore, to the right of the author of an adaptation. The courts subsequently confirmed that, as a result, the performer, and through the performer by contract the producer, benefited not only from rights of reproduction and distribution but also of broadcasting and public performance (Federal supreme Court, 31 May 1960).

Law on the Administration of Copyright and Related Rights of 9 september 1965, 1965 BGBl. I, p. 1273 (with subsequent amendments).

40 Ulmer, E., Letter from Germany, 1965 Copyright 275.

41 Ibid.

42 Under the 1901 Act as amended in 1910, in certain cases legal entities were recognised as authors of works. Over the years, the courts (the Reichsgericht and the Kammergericht) repeatedly recognised the film producer as the author of a cinematographic work (see in particular $106 \mathrm{RGZ} 365$ and $1924 \mathrm{JW}$ 413). For a discussion of this case law see Berthold, F.J. \& V. Hartlieb, H. in: Filmrecht (Munich Berlin, Beck Verlag, 1957). Early drafts of the 1965 Act had proposed continuing to recognise the producer as the author of a film. However, the 1965 Act provided that author's rights in cinematographic works vested in the intellectual creations of individuals (the co-authors of the film), and granted the film producer a related right in the picture carrier.

43 Ulmer, E., op. cit. at 277.

44 See also the decision of the Federal Constitutional Court, which upheld this exemption, in 1972 GRUR 485.

Ulmer, E., op. cit. at 278.

46 Ibid. at 283.

47 Ibid. at 285.

48

Ibid. 
Kreile, Reinhold, The 1989 Amendment to the German Copyright Act, 10 Copyright world 24 (1990).

Art. $93(2)$ of the Law Establishing the Federal Constitutional Court.

1972 GRUR 485; 1972 GRUR 481; 1972 GRUR 487; 1972 GRUR 488; 1972 GRUR 491. For commentaries in English on these cases on which the author has relied see Dietz, Letter from Germany, 1973 Copyright 93; and Rumphorst, 3 IIC 405 (1972).

See also 3 IIC 395 (1972).

Decision of the Federal Constitutional Court, 25 October 1978, 84 UFITA 317 (1979); see also Reute, The Kirchenmusik Judgment Constitutional and Intellectual Property Rights, (1980) EIPR 198.

1985 BGB1. 1, at $1137 ; 1985$ Copyright 368 .

Möller, Margret, 1986 Copyright 271, 272.

For an account of the law and practice with respect to remuneration for private copying in Germany see Kreile, $R$., Collection and Distribution of the Statutory Remuneration for Private Copying with Respect to Recorders and Blank Cassettes in Germany, 23 IIC 449 (1992).

Humme1, Marlies, Die volkswirtschaftliche Bedeutung des Urheberrechts, Gutachten im Auftrag des Bundesministers der Justiz, No. 125 in der Schriftenreihe des IFO-Instituts für Wirtschaftsforschung, (Berlin \& Munich, Duncker \& Humbolt, 1989).

Dietz, A., 1990 Copyright 56.

Supra note 57, quoted from the English summary of the report, at $226-7$.

For a brief account in English see Kreile, $R .$, supra note 49, op. cit.

1990 BGBI. Part II, at 885 et seq.

1993 BGBl. Part I, at 910. For an English-language translation of the Amendment Act see 25 IIC 51 (1994).

Council Directive No. 91/250/EEC of 14 May 1991, OJ EC No. L122, at 42 ; 22 IIC 676 (1991).

Federal Supreme Court Decision, BGH 1985 GRUR 1041, 1048 Inkassoprogramm.

Entered into force 24 June 1995.

Council Directive No. 93/98/EEC of 29 October 1993, OJ EC No. L290, at 9 .

Decision of 20 October 1993 (case C-92/92 and C-326/92 Phil Collins $v$ Imtrat Handelsgesellschaft $\mathrm{mbH}$ and Patricia Im-und Export Verwaltungsgesellschaft $\mathrm{mbH}$, Leif Emanuel Kraul and EMI Electrola $\mathrm{GmbH}$ ), in which the Court decided that the ban on discrimination on the basis of nationality provided for by Article 7 of the Treaty of Rome applies to the law on copyright and related rights and means that nationals of other Member States must receive equal treatment to that given to nationals under the Copyright Law in Germany. 
Article 6 of the Directive.

69 Council Directive 93/83/EEC of 27 September 1993 on the coordination of certain rules concerning copyright and rights related to copyright applicable to satellite broadcasting and cable retransmission (OJ No L 248, 6.10.93, 15); Directive 96/9/EC of the European Parliament and of the Council of 11 March 1996 on the Legal Protection of Databases (OJ EC No. L77, at 20).

70 Nordemann, W., A Right to Control or Merely to Payment? - Towards a Logical Copyright System, 11 IIC 49 (1980).

71 Schricker, op. cit., Introduction, Section 3, at 54-56.

72 Ibid., Sec. 4, at 56-58. 


\section{PART III COPYRIGHT AND PUBLIC POLICY}

The noblest motive is the public good

Sir Richard Steele

Chapter 8: Introduction

The introduction to this study was prefaced by a quotation from Lord Macaulay, the British 19th century author and statesman, which also provides a starting point for the concluding chapters: "The system of copyright has great advantages and great disadvantages, and it is our business to ascertain what these are, and then to make an arrangement under which the advantages may be as far as possible secured, and the disadvantages as far as possible excluded".

The advantages of the copyright system as generally acknowledged, may be summarised as follows. The copyright system guarantees the personal interests of the author in his work. It is also what Macaulay described as the "least objectionable" way of remunerating men of letters by providing mechanisms for authors and other right owners to obtain economic rewards for their efforts. By securing such financial rewards, it stimulates creativity, thereby in the words of the statute of Anne encouraging "learned men to compose and write useful books", and, in the modern world, investment in the creation of works such as films and works of architecture, in addition to providing the economic basis for the film, publishing, broadcasting and record industries. Finally, it answers to the general public interest in facilitating and promoting the widest possible availability of copyright protected material to the public, thereby encouraging both learning and the progress of science.

However, from the inception of the copyright system, there has been a built-in tension between the interests of the author on the one hand and those of the public on the other. It is seen to be in the public interest that authors and other right owners 
should be encouraged to publish their works so as to permit the widest possible dissemination of works to the public at large. "If the ideas and experiences of creators can be shared by a wide public in a short space of time they contribute to the advance of society." 1

Copyright is a monopoly.... It is good that authors should be remunerated; and the least exceptionable way of remunerating them is by a monopoly. Yet monopoly is an evil. For the sake of the good we must submit to the evil; but the evil ought not to last a day longer than is necessary for the purpose of securing the good. ${ }^{2}$

Thus, while copyright protection is justified by the public interest, the State imposes certain limitations thereto, again in the public interest. Copyright is always of limited duration; thereafter, the works fall into the public domain and may be used freely by all. Some limited uses of protected subject-matter are free, e.g. quotations, the use of short excerpts, and even, in some countries, copies made for private use. Copyright works may be subject to compulsory licensing with the result that the copyright owner cannot prevent the use of his work. In some circumstances, exclusive rights may only be exercised collectively through a representative body.

Striking the balance between individual and collective interests is an extremely complex procedure and cannot be done effectively unless account is taken of the possible repercussions in all sectors of society. That this is so, is borne out by the controversy associated with the legislative process in matters of copyright today, at the national and international level, in view of the many conflicting interests involved. "Broad principles tend to be buried under bitterly contested narrow issues" ${ }^{3}$

In setting limitations, and making such decisions as the period of duration, the extent to which free use may be made, limiting exclusive rights in favour of compulsory licensing, etc., the State makes choices in the light of its various policies - not only cultural but also economic and social policies. Some States, in striking the balance between the copyright owners and the public interest, lean in favour of the former, others in favour 
of the latter. The consequences of these choices may not be as anticipated. The potential of copyright as an instrument of policy in the hands of the state still remains to be recognised by many governments. The cultural identity of a country may be promoted or damaged by the government's decisions as to the categories of creators and works to be protected, the limitations on protection to be permitted, and so on. There is a continual need, therefore, for states to reassess, in the light of existing technical developments and those that may be anticipated, "what measure of protection is needed to bring about the creation and production of new works and other material within the copyright sphere." 4

This begs several questions, however. First, does the protection afforded by copyright legislation adequately serve the purposes for which it is intended and, in particular, does it serve as a stimulus to creativity? The functions of copyright have themselves been called in question. The arguments deployed in favour of doing away with the system and the suggested alternatives thereto are discussed below in chapter 9. If the premise is accepted that copyright is necessary, how far should these rights be limited in the public interest? How long should they last? There is a trend towards extending the period of protection of copyright owners. To what extent is this justified? These questions are discussed below in Chapter 10.

In recent years, the interrelationship of copyright laws with economic policies has become clear as a result of studies carried out into the economic contribution of the copyright-based industries to national economies. Some years ago, skilbeck calculated an international value for copyright on the basis of an average from the reports in four countries (Netherlands, Sweden, UK and USA). She estimated the international average contribution of the copyright industries at $2.7 \%$ of national income in 1988.5 In the meantime, national studies on the economic importance of copyright have been published showing a significant increase in this contribution. Thus in the UK, the copyright industries accounted for $3.6 \%$ of GDP (Gross Domestic Product) in $1990^{\circ}$; in the USA, the core US copyright industries' 
share of GDP was 3.7\% in $1993^{7}$. A German report published in 1989 on the basis of 1986 figures arrived at a figure of $3.6 \%$ of GDP for the copyright industries, including software ${ }^{8}$. A New Zealand report published in 1992 on 1988 figures resulted in a figure of $3.2 \%$ for these industries. ${ }^{9}$

Creation can be encouraged or discouraged, depending on the status assigned creators by society. Copyright, whose position has been complicated by the development of new technologies, is a decisive factor. The production policies of commercial distribution of works of the mind are determined primarily, and much more strictly than before by market principles. Accordingly, legal standards are being drafted or revised in order to adjust classical copyright laws to the new economic imperatives. ${ }^{10}$

The economic importance of copyright made the so-called cultural industries a key factor in the international trade negotiations in the context of the Uruguay Round of the GATT Negotiations concluded in December 1993, which led inter alia to the adoption of the Agreement on Trade-Related Aspects of Intellectual Property Rights, Including Trade in Counterfeit Goods (the TRIPS Agreement) signed in Marrakesh, Morocco, on 15 April $1994 .{ }^{11}$ Simon has described the relationship between copyright and trade as follows :

International trade may sound alien to copyright and other intellectual property holders, but it is not. Trade is merely the exchange of one class of products for another--products of the mind in this instance--travelling across borders. The products of imagination and creativity are increasingly replacing land and natural resources as the basis for productivity, increased economic welfare and wealth. Works and inventions are today very much an integral part of trade. Treating them as an element of trade policy neither diminishes nor corrupts the value of intellectual creativity. Rather it provides a rational extension to the basic laws and policies which nations have established to nurture and promote these activities. ${ }^{12}$

The economic and social aspects of the copyright debate are further discussed below. 
Stewart, S.M., International Copyright and Neighbouring Rights (London, Butterworths 1983), para. 1.05.

Macaulay, in: Hansard, Vol. 56, 5 February 1841, at 347-348.

3 Chafee, Zechariah Jr., Reflexions on the Law of Copyright, 45 Columbia Law Rev. 503, 719 (1945).

4 Cornish, W., Intellectual Property: Patents, Copyright, Trade Marks and Allied Rights (London, Sweet \& Maxwell, 1st ed. 1981), at 309.

5 Skilbeck, Jennifer, The Economic Importance of Copyright (London, International Publishers' Association, 1988).

6 Price, Tristan, The Economic Importance of Copyright, Common Law Institute of Intellectual Property, London, 1993.

7 Siwek, Stephen E. and Furchtgott-Roth, Harold, Copyright Industries in the US Economy 1977-1933, International Intellectual Property Alliance, January 1995.

8 Hummel, Marlies, The Economic Significance of Copyright in the Federal Republic of Germany, Institut für Wirtschaftsforschung, Munich, 1989.

9 Copyright Council of New Zealand, Employment in Copyright Based Industries, 1993.

10 Unesco, Third Medium-Term Plan (1990-1995), adopted in November 1989, para. 195.

11 The TRIPS Agreement deals, inter alia, with copyright and related rights. It sets standards for the member states of the World Trade organisation as regards the availability, scope and use of intellectual property rights generally, covering not only copyright and related rights but also trademarks, geographical indications, industrial designs, patents, layout-designs (topographies) of integrated circuits, know-how (undisclosed information) and control of anti-competitive practices in contractual licences. It includes also provisions for the enforcement of intellectual property rights and dispute prevention and settlement measures.

12 Simon, Emery, The Integration of Intellectual Property and Trade Policy, in "Economy and authors' rights in the international conventions", ALAI Geneva study session 1994, Groupe Suisse de I'ALAI et les auteurs, Berne 1994, at 33 . 
Chapter 9: The Functions of Copyright Revisited

A former US Librarian of Congress, writing in 1949, asserted that:

\begin{abstract}
determination of sound copyright policies raises, alike in the domestic and foreign field, the fundamental issues of our day: preservation of personal initiative with greater equality of opportunity; avoidance of the evils of monopoly with a minimum of state control; freedom and integrity of thought, speech, and communication reconciled to media of mass communication. Copyright properly understood and wisely handled may be at the same time a powerful stimulus to creation and the means of opening the channels of dissemination of thought, information and debate. Misunderstood, and with its true purposes lost sight of, copyright can become a limitation on creation and a barrier to free interchange and expression. Like many other products of man's genius in the realms both of science and of the law, it has a capacity for good or evil depending on his understanding and the use he makes of it... The balancing of conflicting interests and the weighing of ... testimony should be done by others with a broader perspective and in a spirit which makes the public interest the paramount test. ${ }^{1}$
\end{abstract}

The functions of copyright must not therefore be lost sight of . As we have seen, these have to a great extent been taken for granted.

The general function of copyright seems but rarely to have figured as a topic of debate ... all that can generally be gleaned is a few introductory statements to the effect that copyright is based on the principle of the labourer being worthy of his hire and that copyright has a stimulating effect on cultural activities. ${ }^{2}$

However, some very valuable analyses of these functions have been published in the last half century. In particular, there is a rich literature on the subject in the United States of America, both in connection with the long-drawn out debates on the revision of the Copyright Act of 1909, which lasted until 1976, and subsequently.

\title{
Chafee's Six Ideals of Copyright
}

In 1945, Professor Zechariah Chafee in a well-known article (described by Barbara Ringer as "probably the best single work on copyright law ever published in English" ${ }^{3}$ ) posed the question "What is it that the law of copyright is really trying to 
accomplish?" " He postulated six ideals of copyright law, each being a desirable end in itself. Three of his six ideals were affirmative, in that they favoured protection of the copyright owner. The others he described as negative, in that they tended to limit the scope of protection.

His first ideal was complete coverage: "If a person has invented some new collocation of visible or audible points, - of lines, colours, sounds or words", the law should protect this new collocation. This ideal concerns what is protected, what the author has given to the world. The second ideal he described as a single monopoly, i.e. copyright means the sole right to produce or reproduce the work or any substantial part thereof in any material form whatsoever. The essential principle is the author's right to control all the channels through which his work or any fragments of his work reach the market. The second ideal concerns what is protected against, what an imitator or appropriator must not do. According to the third ideal, protection should be international. Copyright law should facilitate the free flow of ideas and imaginative creations across national boundaries by giving the same protection to every author, wherever he lives or creates.

His other three ideals tended to limit protection. The fourth ideal was that protection should not extend substantially beyond the purposes of protection; he suggested that this ideal requires more attention than any other. Copyright being a monopoly is open to objection; it burdens competitors and the public. It is permitted and encouraged because of its advantages. However, the burdens must not outweigh the benefits. To ensure this result one must examine who is benefited and how much and at whose expense. The fifth ideal was that the protection given the copyright owner should not stifle independent creation by others. Nobody else should market the author's book, but other people should be able to use it. The world goes ahead because each of us builds on the work of our predecessors. Progress would be stifled if an author were to be granted a complete monopoly for a long period. Some use of the contents of a work must be permitted in connection with the independent creation of other authors. The very policy 
which leads the law to encourage the creativeness of an author also justifies it in facilitating the creativeness of others. The ideas in a book are not protected but the expression is. Quotation must be allowed; plagiarism prohibited. According to the sixth ideal, the legal rules governing copyright should be convenient to handle. They should be certain, readily understood, not unduly complicated, and as easy as possible to apply in order to facilitate the avoidance of litigation.

Few commentators on copyright would disagree with these principles as ideals to strive for, and as chafee points out: "The history of copyright law shows a somewhat jerky progress towards realization of the six ideals." 5

It is the fourth ideal which begs the question of the functions of copyright. For Chafee:

The burden which the monopoly imposes on readers and competing publishers should be roughly limited to what will produce the following benefits: (a) for the author, to supply a direct or indirect pecuniary return as an incentive to creation and to confer upon him control over the marketing of his creation; (b) for the surviving family, to give a pecuniary return which will save them from destitution and impel the author to create, without allowing the family to abuse a prolonged monopoly; (c) for the publisher, to give a continued pecuniary return which will indirectly benefit the author and yield to the publisher an equitable return on his investment, but which will not prevent the public from getting easy access to the creation after the author's death. ${ }^{6}$

Chafee put the emphasis on the economic justifications for copyright, namely, that it provides a pecuniary return to the author, his family and his publisher, thus stimulating creativity and promoting the general well-being of society. As we have seen, the economic and public interest rationales are the basic justifications for copyright in the Anglo-American system. Other laws and commentators lay greater emphasis on the moral justifications for copyright, based on the creator's rights in his creation deriving from natural law and on the obligations of society towards him as well as the notion of just reward for labour.

Both the economic and moral justifications for copyright have, however, been exposed to critical analysis in the UK and USA to 
a greater degree than elsewhere." A similar debate has also taken place since World War II in Scandinavia. ${ }^{8}$ Let us take a look at the validity of Chafee's ideals in the light of this debate. His three affirmative ideals favouring the protection of the copyright owner can only be realised if there is general acceptance of the moral and economic functions of copyright. In Chapter 10 we shall explore Chafee's negative ideals, which tend to limit the scope of protection.

\section{The Moral Justifications for Copyright Revisited}

The arguments against the moral justifications for copyright include the following: the personal interests of an author in his work do not justify giving him exclusive rights. The rationale for an author's work being his property because it is his creation is unsound. "We do not ordinarily create or modify property rights, nor even award compensation, solely on the basis of labor expended." Moreover, literary property is unlike other kinds of property since it is limited in scope. It is limited in time and protects only the expression of the author's idea, not the idea itself. Copyright is not the only means of protecting the moral rights of the author; the author's personal interests in his work could be given statutory recognition outside the copyright framework or according to common law rules of tort.

As regards the moral requirement to reward labour, it is suggested that the expectation of financial reward is not the only reason for authors and other artists to create. They are not motivated primarily by monetary interests; many are impelled to create as part of their personality, creation being in their nature. As Plant observed: "There is ... an important group of authors who desire simply free publication; they may welcome, but they certainly do not live in expectation of, direct monetary reward." 10

Some authors to this day pay to have their books published, when they cannot find a publisher ready to take the risk. Publishing 
brings prestige with it and, in the case of academics, may lead to promotion and higher salaries.

For such writers copyright has few charms. Like public speakers who hope for a good press, they welcome the spread of their ideas. Erasmus went to Basle in 1522, not apparently to expostulate with Frobenius for daring to print his manuscript writings, but to assist the printer in the good work. The wider the circulation, the more universal the recognition the author would receive. ${ }^{11}$

Besides, it is argued, the copyright system does not especially reward creators of great works of lasting social value. It favours instead the commercial, popular work with large sales.

The amount of the reward is determined solely by the public's willingness to pay for the work. More importantly, there is no selfevident reason why authors deserve compensation fundamentally different from that given to those who perform other kinds of work; yet workers on the whole are not paid with respect to the value of their work to society, but in the amount necessary to persuade them to perform their work, plus any premium resulting from the scarcity of similar workers. ${ }^{12}$

Other motives for creation include the desire for fame and recognition. Government subsidies could provide creators with basic financial security. Many governments as well as other institutions already do award substantial sums to creators in the form of grants and prizes. Alternatively, authors, publishers and buyers of works could make arrangements among themselves to provide authors with sufficient money to produce them. In ancient times and in the middle ages, it is argued, authors wrote books even though there was no copyright protection. They still contrived to secure a price for their product. Governments could take over the role of the patron and pay for works to be produced. "It is not unfair to finance through taxes the creation of works that benefit not only those who buy them but also many other members of society as well". ${ }^{13}$

Plant suggested that:

Patronage itself may not be wholly an evil. There seems to be no reason why a person who wants certain things written and published should not be at liberty to offer payment to suitable people to do the necessary work. If the task is uncongenial, some authors will need high remuneration, and others will no doubt decline any terms... ${ }^{14}$ 


\section{The Economic Justifications for Copyright Revisited}

As regards the economic justifications for copyright, the question to be answered is what would happen were copyright protection to be abolished. Plant argued that professional writers in the past secured a price for their product in the absence of copyright, provided a market existed for it. In support of this thesis, he drew attention to the often quoted example of English authors who in the nineteenth century were paid by US publishers in spite of the fact that their works were unprotected there.

During the nineteenth century anyone was free in the United States to reprint a foreign publication, and yet American publishers found it profitable to make arrangements with English authors. Evidence before the 1876-8 Commission shows that English authors sometimes received more from the sale of their books by American publishers, where they had no copyright, than from their royalties in [the UK].... In the first place, there was the advantage, well worth paying for, which a publisher secured by being first in the field with a new book.... secondly, there was a tacit understanding among the larger publishers in America that the books published by one should not be published by another. ${ }^{15}$

Plant concluded that the abolition of copyright need not therefore result in the complete abandonment of the business of book production either by publishers or by professional authors. He did concede, however, that "More authors write books because copyright exists, and a greater variety of books is published; but there are fewer copies of the books which people want to read." 16

Breyer, in a very thorough analysis of this question written in 1970, of which space only permits a very brief overview here, came to not dissimilar conclusions. He examined whether the benefits of copyright protection are sufficiently valuable to justify not only retaining it but also extending its scope. His analysis was based on the book trade, and focused on the rights of authors and their interrelationship with publishers. He started from the premise that copyright restrictions are justified only when necessary to achieve some important social benefit. Abolishing copyright in books would induce competition in the production and sale of high-volume titles, which would 
lead to lower prices and wider distribution. However, if competitive prices fell too low, author and publisher would be discouraged from producing the book in the first place and the reader would be worse off. The price of text books would fall; this would have particular social value. He argued that the absence of copyright protection would not lead to the abandonment of the business of book production. Several factors would help to maintain the production of many novels and popular works of non-fiction (tradebooks).

Without copyright, a publisher should still have a few weeks of "lead time" to recoup some of his expenses before copiers can reproduce his book and distribute it to local book sellers. Further, copiers may find that it does not pay to copy "low volume" trade books, i.e. books that sell only a few thousand copies. Not only is the market for each book small, but also the copier must fear that the book's publisher will retaliate by cutting his price to variable cost....17

Thus, the best defence against a rival publisher would be a lowprice policy. This was the policy the US publishers adopted in relation to English works. As Plant explained:

American editions might cost one-half as much as the English issue; one-quarter or even one-eighth of the English price was very frequent. In such circumstances, the American public enjoyed cheap books, the American publishers found their business profitable, and the English authors received lump sums for their advance sheets and royalties on American sales. ${ }^{18}$

Abolishing copyright would eliminate the administration costs of obtaining permission to reproduce a work. In this connection, Breyer drew attention to the high costs of copyright administration in clearing rights, for example, for radio and television broadcasting. According to his analysis, the case for copyright in books is weak and he suggested that to abolish protection would not produce a very large or harmful decline in most kinds of book production. It would be possible to sustain the publisher's revenue in other ways. For example, buyers of textbooks are few in number and could contract directly with the publisher. Government subsidies could maintain publishers' and authors' revenues. He pointed out that in any case at that time Government subsidised scientific writing by paying for nearly two-thirds of all research and development work done in America as well as by spending large sums on the dissemination of its 
results. The disadvantages of substituting Government money for funds raised through the copyright marketplace, however, would be serious. It would be difficult to obtain the necessary appropriations from Congress to support novels and other works not aimed at the educational/scientific market. The risk of censorship would increase.

He concluded that, "Taken as a whole, the evidence now available suggests that, although we should hesitate to abolish copyright protection, we should equally hesitate to extend or strengthen it". ${ }^{19}$ He suggested that certain questions should be posed in considering whether or not to extend copyright protection:

One should first ask: What forces are at work to sustain production in the absence of copyright protection? This query leads in turn to a series of other questions: (a) What other forces might inhibit competitors from responding with sufficient speed and ferocity to deprive the initial producer of a profit? (b) Does the Government now, in any event, pay for production through subsidy, and should it do so? (c) In the absence of protection, are buyers likely to find ways to channel sufficient funds to producers to maintain production?

Second, one should ask: To what extent may protection prove harmful? (a) Will it, by driving up the cost of copies, seriously diminish circulation? (b) Are the administrative or "transactions" costs involved likely to be high enough to impede the circulation? (c) Can copyright be used to inhibit competition throughout an industry? ${ }^{20}$

The merit of the major articles referred to above was that they renewed discussion of the functions of copyright, and in particular, of the economic rationale therefor, in both the UK and the USA, a debate in which many other distinguished commentators have participated. ${ }^{21}$ While Professor Breyer concluded that there was an "uneasy case for copyright", others who studied the economic rationale for copyright came to rather more positive conclusions on the subject.

One US commentator, for example, writing at about the same time in a study of book publishing, concluded that copyright permits the publisher:

to profit substantially on some books (where other publishers would otherwise jump in and divide the market) so as to pay for those books that produce losses. That is, the monopoly right permits the publisher to take risks that he would not take if his more successful books were subject to reprinting without permission and without fee. Thus the copyright promotes the public interest by encouraging a great variety of books to be published, many of them economically marginal, in the 
hope that some will be highly profitable, and it does this without causing significantly higher book prices on account of monopolistic pricing. ${ }^{22}$

Similarly, Ljungman, in his essay on the function of copyright in present day society, concluded that copyright has the function of encouraging investment in the publication of works.

A work of literature should be printed, a drama should be staged or filmed, a musical composition should be recorded and so forth. Without copyright, or at least without a knowledge of and control over utilisations of the same work, one's chances of financing these measures would be sensibly diminished if not eliminated.... Individual copyright channels investments in accordance with market demand. Supplementary measures by the state are preeminently desirable, but neither system would function properly without the protection of copyright. ${ }^{23}$

Ljungman considered that copyright served two other major purposes; first, if copyright did not exist,

an author would forfeit the chance of any further proceeds from his work as soon as it was published or performed ... remuneration for the initial utilization of a work would have to be made large enough to cover all the author's overheads and provide him with reasonable sustenance - all in one fell blow. Copyright on the other hand makes it possible to divide the author's remuneration between several users over a long period of time. ${ }^{24}$

Moreover, and here we come once again to the public interest, "Exclusive rights benefit the actual distribution of the fruits of intellectual labour. Copyright makes it possible, without any risk to the author's interests, for new works to be placed at the disposal of interested parties with a view to their possible reproduction, performance etc." 25

Finally, he pointed out that contractual agreements concerning exclusive rights to the material would not provide protection against publication by third parties.

Another article by Landes and Posner, written in 1989, discussed the evolution and major doctrines of the law of copyright from an economic standpoint. The authors addressed themselves specifically to the question "to what extent copyright law can be explained as a means for promoting efficient allocation of resources."26 For them the economic rationale for copyright protection is to prevent free-riding (appropriation without 
payment) of the author's expression. Starting from the premise that the "distinguishing characteristic of intellectual property is its public good aspect", they suggested that:

Copyright protection - the right of the copyright owner to prevent others from making copies - trades off the costs of limiting access to a work against the benefits of providing incentives to create the work in the first place. Striking the correct balance between access and incentives is the central problem in copyright law. For copyright law to promote economic efficiency, its principal legal doctrines must, at least approximately, maximise the benefits from creating additional works minus both the losses from limiting access and the costs of administering copyright protection. ${ }^{27}$

In the absence of copyright,

anyone can buy a copy of the book when it first appears and make and sell copies of it. The market price of the book will eventually be bid down to the marginal cost of copying, with the unfortunate result that the book will probably not be produced in the first place, because the author and publisher will not be able to recover their costs of creating the work. The problem is magnified by the fact that the author's cost of creating the work, and many publishing costs (for example, editing costs), are incurred before it is known what the demand for the work will be. Uncertainty about demand is a particularly serious problem with respect to artistic works, such as books, plays, movies and recordings. Even with copyright protection, sales may be insufficient to cover the cost of expression and may not even cover the variable cost of making copies. Thus the difference between the price and marginal cost of the successful work must not only cover the cost of expression but also compensate for the risk of failure. If a copier can defer making copies until he knows whether the work is a success, the potential gains from free riding on expression will be even greater, because the difference between the price and marginal cost of the original work will rise to compensate for the uncertainty of demand, thus creating a bigger profit potential for copies. So uncertainty generates an additional disincentive to create works in the absence of copyright protection. ${ }^{28}$

These analyses are particularly helpful in determining the extent to which copyright should be extended to cover new forms of works and the scope of the rights granted. Light points out that, in the context of the USA, the phrase "to promote the progress of science and the useful arts" in the copyright clause of the Constitution embodies the economic rationale for copyright, namely, "to enhance the public welfare by encouraging artistic endeavours through the creator's self-interest". Similarly, the constitutional limitation of the term of copyright protection is embodied in the term "by securing for limited times ... the exclusive right to their respective writings...". Congress may therefore not grant nor the courts enforce copyright protection 
which would impede the progress which is the very purpose of copyright. Thus, he suggests that "Where the extension of copyright would appear to be contrary to this constitutional purpose an analysis of the economic justification should be undertaken" . 29

\section{Alternatives to Copyright}

As seen above, the suggestion has also been made that, while some mechanism is needed to ensure that authors are remunerated,

it does not necessarily follow that the grant of a copyright monopoly is the only such device, nor that it is the most desirable device. If we wish to encourage works which require long periods of research or high costs of creation before they reach the publishing stage, it may be preferable to support authors during the period of production rather than during the moment of potential income protected through the copyright laws. This can be done through private patronage by taxexempt foundations, universities, and the like, or even by government support for desired literary creation. ${ }^{30}$

A proposal was even put forward in the form of a private member's bill to the Swedish parliament, the Riksdag, in 1960, which gained some support, calling for the Government's pending copyright bill to be rejected and replaced by a grant of 20 million kronor "for the support and promotion of works of art and literature" to be distributed by the Government "with due consideration towards creative writers and artists having to contend with financial difficulties". ${ }^{31}$ This proposal was no doubt inspired by two pieces of Norwegian legislation, introduced as long ago as 1948 and 1956, which replaced individual rights by Government subsidy and which are still in force. The 1948 law dealt with the resale of works of art but, instead of introducing a resale right for artists or droit de suite, introduced a $3 \%$ purchase tax on public sales of all fine art. "The whole of the surcharge is paid into a fund, administered by artists and representatives of the state, for the support of deserving elderly Norwegian artists and promising young ones." 32 The other similar solution was embodied in the King's Fund set up for performers and producers of phonograms in 1956, which provided for remuneration derived from the public performance of 
phonograms to be distributed collectively between Norwegian performers. ${ }^{33}$ More recently, both Norway in 1981 and Sweden in 1982 adopted legislation imposing taxes on the sale of certain recording equipment (audio and video blank tapes and recording equipment in Norway and blank audio tapes and blank and prerecorded videocassettes in Sweden), but the bulk of this revenue benefits the exchequers of these countries. In Norway, approximately $20 \%$ of the revenue collected is paid out by the Department of Culture to right owners to be used for collective purposes. In Sweden, of the total collected in 1988 only $2.3 \%$ found its way to the copyright and related rights organisations. ${ }^{34}$

These developments in the Nordic countries represent a movement away from individual rights to collectivist solutions controlled by the state.

Copyright may be an inefficient tool for rewarding authors, but the idea that the revenue that authors and other right owners derive from their individual rights could be replaced by private patronage or state support is difficult to support on economic or social grounds.

If it is accepted that a society's culture rests on the freedom of expression of individuals, then it follows that the individual must have a forum for that expression. In the world today, that forum includes the market place, and, as we have seen, one of the functions of copyright is to enable the author to sell or otherwise derive revenue from the products of his activities. ${ }^{35}$

Private patronage was the rule prior to the introduction of copyright legislation in the eighteenth century. At that time, however, there was a very restricted reading public. Readers, as pointed out by Lord Mahon in 1842,

in truth, were then [in the last quarter of the seventeenth century] only of two classes, of the court or the college - either the gay companions of Charles the second ... or the laborious student.... Reading had then in no degree, as now, penetrated and leavened the great mass and body of the people. The inferior authors, therefore, were left to starve or to beg as they could.... But with the better, or, if you please, the more fortunate authors, the want of purchasers 
to their books - the want of a public in fact - was supplied by a system of munificent private patronage. ${ }^{36}$

Subsequently, however, "a reading public began to arise, and then it was that copyright became for the first time a question of interest" . 37

Limited private patronage still exists today in the form of prizes for literary, artistic or musical works, in the private commissioning of works and in commercial sponsorship. However, it is not feasible for such private patronage to be sufficiently extensive so as to constitute a valid substitute for the copyright system. While it may provide financial support to the few, it could not provide a sufficient incentive or stimulus to creativity in general. To replace copyright, direct payment of all creators would require huge increases in the amounts available for this purpose at present. Such patronage would also deprive authors of financial and artistic independence, bringing with it the danger that the creator could be obliged to create to order and not at the promptings of his own genius and imagination. As Goldstein has commented: "Patronage supports only those authors whose creative efforts meet the patron's taste. Patronage depresses authorship by shutting the author off from the wider audience that he might hope to reach. "38 In any event, private patronage is far too haphazard a system for a responsible government to use as the basis of its cultural policy in the late twentieth century.

Patronage by the state as a substitute for copyright protection has the overriding disadvantage of resulting in state control with the attendant risk of censorship of artistic creativity. Moreover, as Ricketson has pointed out "immense administrative questions would immediately arise, to say nothing of the problems of political influence and nepotism and the age-old question of 'Where's the money coming from'?". "The countries which formerly had socialist economies did recognise the social importance of the author and the international copyright system. At the same time, however, the means of publishing and disseminating literary, artistic, musical and dramatic works, films, phonograms and other subject-matter protected by copyright was in the hands 
of monopolies, such as state publishing houses, film companies, record companies and state-controlled theatres and cinemas. Thus, the selection of the works to be published was made under state control.

Such state control is clearly incompatible with the overriding public interest that artists should be at liberty to create without any limitation on their freedom of expression. In such a system, aesthetic considerations may be subject to political ideology, the whims of government employees acting as selfappointed arbiters of taste, or the need to conform to the standards of a reactionary establishment. "I can conceive of no system more fatal to the integrity and independence of literary men, than one under which they should be taught to look for their daily bread to the favour of ministers and nobles". 40

State patronage can operate in various ways and at different levels. It can take the form of subsidies or pensions for authors. The collectivist systems referred to above are one way. The grant of tax relief on the earnings of authors has been suggested as another solution but that would only be of any help to those already having an income on which to pay taxes. Moreover, no state could afford to substitute the income derived by creators from copyright by direct state subsidy. On the basis of statistics available to him in 1976, Ljungman made the calculation that, at that time, there were more than 17,000 persons deriving an income in sweden from literary and artistic activities amounting to an amount of approximately 100 million Swedish kronor. Although such a figure was "a negligible item in the national economy",

Their importance in the field of cultural policy on the other hand would seem to be considerable. In the present day situation, at least, it would certainly not be easy to secure a new annual state grant of the same proportions for the benefit of Swedish authors ... the automatic functioning of copyright protection produces the money in a way which does little to prejudice the planning of the national economy. ${ }^{41}$

At this distance in time, Ljungman's point has been greatly reinforced by the various studies into the economic importance of the copyright sector, referred to in more detail below, which 
have shown that the copyright-related industries account for over $3 \%$ of national income in some countries.

It is clear that patronage - whether private or state - is inadequate to assure the freedom upon which the cultural life of a modern state should depend. That freedom should extend not only to the creator's expression but also to the public's choice, that is, the test of the market.

It may be that state patronage will continue to have a role to play in supporting certain cultural activities which through their minority appeal or disproportionate expense are unable to compete successfully in the market place. But even in such cases, state assistance should be carefully measured to avoid the uneven distribution of financial support leading to minority activities being removed still further from the competition of the market place.

In this connection, it may be noted that there has been a tendency for much of the revenue derived from the collectivist solutions in existence in the Nordic countries and referred to above to be channelled not to the individual right owners whose works have given rise to the revenue but to support various projects considered worthy by the state. The revenue is paid either to funds for the benefit of the young and talented and the old and indigent or to the public exchequer. In the latter case, the money either disappears into public funds or is used for "cultural" purposes determined not by right owners but by the State.

Over thirty years ago, Stuevold Lassen, discussing what he saw as a general trend in copyright law away from individualism towards collectivisation, pointed out the dangers of the collectivist approach then gaining ground in Norway, whose legislation was the forerunner of collectivism in Europe:

It is, admittedly, surprising that during the painstaking preparation of a Copyright Act built on exclusive rights for the author, three subsidiary copyright statutes should come out which completely discard the principle of individual copyright, replacing it with strictly collectivist arrangements. Demands for the extension of authors' and 
artists' rights are met, not with the creation of new prerogatives for the individual but with the introduction of new taxes, and redistribution of the tax money according to principles of social policy. The welfare state has entered the field of copyright law, and has established what has become known as the 'Norwegian' system. Utilisers and consumers are - as long as they pay for what they use free to choose and reject. There is no question of asking anybody's permission; neither the State nor the foundation board nor the artist has a right to prohibit the use. Fees are paid into a fund and redistributed according to rules strongly resembling socialistic principles.

Such a system has obvious disadvantages. It combines the disadvantages of a system of compulsory licensing with the risk that those controlling the disbursements may use their power as a means of censorship. It may also be maintained that collectivisation might deprive the authors of the motive power of their creative activity the hope of a "just remuneration" for their toil.42

Lassen also pointed out that the danger of censorship is inherent in all systems which include a substantial degree of state intervention:

Moreover, the danger seems to be more or less the same, no matter whether the cause of authors being state-paid and the means of communication being state-owned is a general socialisation or merely the State's pursuance of an active policy to stimulate production in the cultural sphere. It is, therefore, hardly contestable that state broadcasting, State-owned theatres, State-subsidised production of films, state-owned publishing houses, state orchestras, etc. may in the long run present a risk of censorship just as dangerous and far more likely to be realised than the direct socialisation of authors' rights. ${ }^{43}$

Collectivisation carries with it other dangers. It has a stultifying effect on creativity:

But it is perhaps no less disturbing a thought that the collective allocation of income payments - mainly according to need - can in the long run undermine the stimulating function of copyright. A successful creative author ... may in the long run cease to feel the urge to contribute towards the maintenance of less successful colleagues. ${ }^{44}$

It also prejudices the international copyright system. Revenue from state taxes escapes the international copyright system altogether and revenue distributed through a collective system also avoids the international allocation to foreign right owners of their share of incoming revenues. In both cases, payments are made for the use of foreign works but only the domestic government or its nationals benefit from the revenue. 
The question of principle, copyright versus patronage, was succinctly argued by Lord Mahon in 1842:

Literary men can never be fairly rewarded by places or pensions. If left to these and these alone, the influence or at least the suspicion, of partiality could never be vanquished. The fairest rule is, to leave them to the patronage of the public, but at the same time to secure to them the full enjoyment of that patronage. The fairest principle is that of rewarding them according to the sale of their works - the fairest test of their merits is the test of time. ${ }^{45}$ 
1 Evans, Luther H., Copyright and the Public Interest, 53 Bulletin of the New York Public Library 4 (1949).

2 Ljungman, Seve, The Function of Copyright in the Present Day Society, 88 RIDA 51 (1976).

3 Ringer, Barbara, The Demonology of Copyright, Bowker Memorial Lecture, US Publisher's Weekly, 18 November 1974, at 30 .

4 Chafee, Zechariah Jr., Reflexions [sic] on the Law of Copyright (Parts I and II), 45 Colombia Law Rev. 503 and 719 (1945). The following paragraphs summarise Professor Chafee's arguments, including much of his own language.

Ibid. at 519 .

Ibid. at 510 .

7 Report of the British Commission appointed in 1878 for the Investigation of the subject of Copyright (London). See also: Birrel1, A., Seven Lectures on the Law and History of Copyright in Books (London, 1899); Breyer S., The Uneasy Case for Copyright: A Study of Copyright in Books, Photocopies, and Computer programs, 84 Harv. L. Rev. 281 (1970); see also: Copyright A Rejoinder, 20 UCLA L. Rev. 75 (1972); Tyerman, B.W., The Economic Rationale for Copyright Protection for Published Books: A Reply to Professor Breyer, 18 UCLA Law Rev. 1100 (1971); Plant A., The Economic Aspects of Copyright in Books, 1 Economica (n.s.) 167 (1934); The New Commerce in Ideas and Intellectual Property (University of London 1953) in: Plant A., Selected Economic Essays and Addresses (London \& Boston, 1974); Light, S.N., Parody, Burlesque and the Economic Rationale for Copyright, 11 Connecticut Law Rev., No. 4, 615 (1979); Gordon, W.J., Fair Use as Market Failure: A Structural and Economic Analysis of the Betamax Case and its Predecessors, 82 Colum. Law Rev. 1600 (1982), Adelstein A. \& Peretz S., The Competition of Technologies in Markets for Ideas: Copyright and Fair Use in Evolutionary Perspective, 5 Int. Rev. of Law and Economics 209 (1985); Kaufmann, Gary, Exposing the Suspicious Foundations of Society's Primacy in Copyright Law: Five Accidents, 10 Colum.-VLA Journal of Law and the Arts, 381 (1986); Gordon, W.J., An Enquiry into the Merits of Copyright: The Challenges of Consistency, Consent, and Encouragement Theory, 41 Stanford L. Rev. 1343 (1989); Landes W.M. \& Posner R.A., An Economic Analysis of Copyright Law, 18 Journal of Legal Studies 325 (1989); Palmer, Tom G., Are Patents and Copyrights Morally Justified? The Philosophy of Property Rights and Ideal Objects? 13 Harvard Journal of Law and Public Policy 816 (1990). Vaver, David, Intellectual Property Today: of Myths and Paradoxes, LXIX The Canadian Bar Review 98 (1990);

See Ljungman, supra note 2; and Lassen, B.S., Collectivism and Individual Rights in Norwegian Copyright Law, 1963 Scandinavian Studies in Law 79.

Breyer, S., The Uneasy Case for Copyright, op. cit. at 289.

Plant, A., The Economic Aspects of Copyright in Books, I Economica (n.s.), No. 167, at 59 (1934).

Ibid.

Light, Sheldon N., Parody, Burlesque and the Economic Rationale for Copyright, 11 Connecticut Law Rev., No. 4, at 619 (1979). 
Plant, Arnold, op. cit. at 60 .

Plant, A., Ibid. at 62 .

Plant, A., Ibid. at 64 and 80.

Breyer, S., Copyright: A Rejoinder, 20 UCLA L. Rev. 75, 77 (1972).

Plant, A., op. cit. at 63 .

Breyer, S., The Uneasy Case for Copyright, op. cit., at 284, and see $321-323$ and $350-351$.

Breyer, S., Copyright: A Rejoinder, op. cit. at 76.

See, e.g., Cohen Jehoram, 20 IIC 485 (1989); De Freitas, 2 Intellectual Property in Business 26 (1990); Gordon, 82 Columb. Law Rev. 1600 (1982); Humme1, 12 IFO-Digest, No. 4/89, at 32; Hurt \& Schuchman, 56 Am. Econ. Rev. 42 (1966); Kasdan, Working Paper, Columbia Law School, October 1966; Landes \& Posner, 18 Journal of Legal Studies 325 (1989); Olsson, 1982 Copyright 130; id., 7 EIPR 179 (1984); Pratt, 1988 Rev. of the LES 159; Uchtenhagen, 1989 Copyright 280 .

Bailey, H., The Art and Science of Book Publishing (1970), at 169 .

Ljungman, op. cit. at 67.

Ljungman, Ibid. at 69.

Ibid.

Landes, William M. \& Posner, Richard A., An Economic Analysis of Copyright Law, 18 Journal of Legal Studies 325 (1989).

Ibid. at 326 .

Ibid. at $328-329$.

Light, Sheldon N., op. cit. at 622 and 623 .

Hurt, R.M. \& Schuchman, R.M., The Economic Rationale for Copyright, $56 \mathrm{Am}$. Econ. Rev. 426 (1966).

Ljungman, S., op. cit. at 55 .

Ljungman, S., Ibid.

Fund Law of 14 December 1956.

For further details see Davies, Gillian \& Hung, Michèle E., Music and Video Private Copying, An International Survey of the Problem and the Law (London, Sweet \& Maxwell, 1993), at 208 and 209.

5 Some passages in this section have been adapted from an article written by the author in 1984: New Technology and Copyright Reform, 12 EIPR 335 (1984).

3 Lord Mahon, moving the recommittal of the Copyright Bill 1842 in the House of Commons, Hansard, April 61842 , at 1349.

Ibid. at 1350 . 
38 Goldstein: Copyright: The Donald C. Brace Memorial Lecture, Journal of the Copyright Society of the USA, Vol. 38, no. 3, 1991 at 109.

39 Ricketson, S., op. cit. at 760 .

40 Macaulay T., Hansard, Vol. 56, 5 February 1941, at 347.

41 Ljungman, S., op. cit. at 79.

42 Lassen, B.S., op. Cit. at $82-83$ and 88 .

43 Ibid. at 87 .

44 Ljungman, S., op. cit. at 85.

45 Lord Mahon, Hansard, April 61842 , at 1358. 


\section{Chapter 10: Limitations on Copyright}

Let us turn now to Chafee's three negative copyright ideals of which the most important is his fourth ideal, namely, that protection should not extend substantially beyond the purposes of protection. In this connection, perhaps the issue that has been most debated in copyright is the question of duration. The fifth ideal that protection should not stifle independent creation by others concerns exceptions to protection, including the Anglo-American concepts of fair dealing and fair use. Finally, limitations on protection are relevant to Chafee's sixth ideal, that the legal rules of copyright should be convenient to handle.

\section{Duration of Protection}

As demonstrated by Part II of this study, the question of how long copyright should last has been a controversial matter from the outset. It has been pointed out that the very first national laws granted rights to authors for limited times on policy grounds, it being considered essential to protect the rights of the public to have access to works. As Ricketson has pointed out:

This 'public interest' viewpoint has continued to pervade all copyright legislation, both nationally and internationally.... Natural rights theories with their focus on the individual (and corresponding absence of attention to the wider interests of the public) have therefore never triumphed in their pristine form and authors' rights, unlike those of other property owners, have remained limited in time.

Nevertheless, partisans of perpetual rights remained vocal for many years and their arguments were met in part by a gradual extension of the term of protection. Following the incorporation of the term of 50 years p.m.a. first as a goal in the Berlin Act 1908 of the Berne Convention and subsequently as the standard of the Berne Convention following the Brussels Conference in 1948, that term came to be considered the norm and to represent a proper balance between the rights of the authors and the public interest. It should be noted in this connection that "the historical development of these norms is also notable for an 
almost complete absence of debate of the policy and theoretical issues involved". ${ }^{2}$

Recently, however, as discussed in Part II with respect to the copyright laws of France, Germany and the United States of America, there has been a move towards extending the period of protection. In 1992, the European Commission put forward a proposal ${ }^{3}$ to extend the period of protection for authors throughout the Community to 70 years p.m.a.. This resulted in the adoption in October 1993 of a Directive harmonising the term of protection of copyright and certain related rights ${ }^{4}$. The Directive provided for a uniform period of protection for authors of seventy years p.m.a. ${ }^{5}$, thus harmonising upwards to the longest period of protection in any Member state, in spite of the fact that only three of the then twelve ${ }^{6}$ Member states previously protected certain works for longer than 50 years p.m.a., namely France ( 70 years for musical works only), Germany ( 70 years for literary, artistic and musical works) and Spain (60 years also for literary, artistic and' musical works). The World Intellectual Property Organisation (WIPO) in 1991 also suggested, in connection with a possible Protocol to the Berne Convention, an extension of the term of protection for authors to 70 years p.m.a. ${ }^{7}$

The Commission justified extending the term of protection as follows in the Preamble to the draft Directive: "The Commission stresses the need to harmonise copyright and neighbouring rights at a high level of protection since these rights are fundamental to intellectual creation and their protection ensures the maintenance and development of creativity in the interest of authors, cultural industries, consumers and society as a whole." 8

It should be noted, however, that the principal concern of the Commission in this respect was to harmonise the period of protection throughout the Community in view of the completion of the Single Market, which took effect on 1 January 1993, so as "to establish a legal environment conducive to the harmonious development of literary and artistic creation in the community". Harmonisation upwards was simpler to achieve in view of the 
difficulties inherent in cutting back acquired rights. Other arguments deployed in favour of the extension included longer Iife expectancy and the desire to protect the interests of the author's direct descendants for two successive generations.

The rationale for WIPO's proposal was similar:

The main reason for envisaging a possible extension of the term of protection was that the 50 -year p.m.a. term of protection (which is the minimum provided for by the Berne Convention) had originally been adopted to make reasonably certain that at least the first generation of authors' heirs should normally be able to enjoy the rights protected, but, because of the continuous increase in life expectancy, such certainty no longer existed. ${ }^{10}$

These proposals did not meet with unanimous approval and, indeed, the proposal to extend the term of protection to 70 years in the possible Protocol to the Berne Convention has since been dropped ${ }^{11}$.

According to von Lewinski, the European Commission's proposals were countered by doubts being expressed as to whether

an author's descendant can participate sufficiently, if at all, in the fruits of his creation. Usually, assignment or transfer of copyright goes to an exploiting enterprise for the entire duration of protection. Therefore, an extension of the term of protection lies primarily in the interest of such exploiting enterprises in regaining their investments. ${ }^{12}$

The extension was also opposed by the Economic and Social Committee of the EU, which favoured harmonisation at 50 years p.m.a. ${ }^{13}$

Following the event, the extension of the period of protection for literary, artistic and musical works under the EU Directive to 70 years in the Member States of the European Union (Member States should have implemented the Directive by July 1, 1995) has been seen as controversial and strongly criticised. This may well be why the WIPO proposal has been withdrawn for the time being. Cornish has argued that 
decisions by reference to much shorter time scales than these. It is only considerations of moral entitlement which can possibly justify even the present minimum term in the Berne Convention...

He points out that the principal argument put forward that the lifespan of authors has increased is without foundation because "this added longevity is brought into account under the existing system of measurement. At least the first generation of inheritors is compensated by that, since it is not argued that children are on average being born to older parents". In his view "it is clear that simple, unsubstantiated pressure from the copyright industries for more protection has been the governing factor in getting the Directive onto the books with such alacrity"... and ..."to say that consumers and society as a whole will benefit is eye-wash". ${ }^{14}$

In the WIPO context, some delegations opposed the proposal for extension, considering that basing an extension of the term on continuous increases in life expectancy was not valid, and asked for further study of the justifications for any extension. It was also suggested that extension of the term of protection would lead to practical difficulties for the access of developing countries to protected works and for the users of works, in general, since the author's heirs were often difficult to find for the purpose of obtaining their authorization. Others argued that extension of the period of protection was justified not only by the increased life expectancy of authors, but also because a longer term of protection would increase the value of copyright. ${ }^{15}$

That a serious discussion of the rationale for the term of copyright protection should be taking place internationally at present, is in itself positive, particularly since, as Ricketson has pointed out, in recent years there has been relatively little discussion of this question, either at national or international levels. ${ }^{16}$ Many commentators start from the premise that any extension of the term of protection necessarily represents progress, and, as Ricketson puts it, those favouring extension of the term have latterly occupied as it were the high moral ground, those opposing extension of the term being put on the defensive to justify the status quo. As Ricketson reminds us, in 
the various debates on the subject of the term of protection leading to the adoption of the term of 50 years p.m.a. as the minimum standard in the Berne Convention, by the Brussels Revision Conference in 1948:

One is hard pressed to find reasoned justifications for the adoption of longer terms of protection. The 50-year post mortem term was taken as a self-evident 'good thing', and the onus was clearly on countries with shorter or restricted terms to justify their deviance from this standard.... One must conclude that the 50-year post mortem adherents had won the higher moral ground in the argument and therefore had their opponents at a disadvantage. ${ }^{17}$

Moreover, as we have observed in Part II, the comparatively recent extensions of term adopted in France and Germany took place without serious debate as to the justification therefor. In France, as already discussed, it was the music publishers who persuaded the French legislators to extend the term of protection of musical compositions to 70 years on the ground that in the field of serious music it was necessary for them to be able to recoup their investments over a longer period than 50 years p.m.a. There was no attempt to justify the extension in the interests of the author or his heirs. The public interest was not even mentioned.

Assuming that there is general agreement with the proposition that authors should be protected during their life time, and for a limited period thereafter, ${ }^{18}$ the point in issue here is how long should copyright last after the death of the author? As Macauley put it: "It can hardly be disputed by any rational man that this is a point which the legislature is free to determine in the way which may appear to be most conducive to the public good."19

The legislature, however, should arrive at what it considers a period most conducive to the public good after debating the issue and taking account of the arguments. That such debate has been scarce in recent times, and that the EU Directive should have been adopted with so little discussion of the issues, is regrettable. Ricketson in his 1992 article, ${ }^{20}$ sought to remedy that deficiency by drawing attention once more to the main arguments, which in former times played such a vital role in the shaping of the modern copyright system, as discussed in part II. 
It is not the aim of the author here to rehearse all these arguments anew, nor does space permit. The following summary focuses on the public policy aspects of the debate.

Since the Statute of Anne first introduced a period of protection for copyright works of 14 years from publication, renewable by the author for a further fourteen years, the arguments put forward in favour of either perpetual rights or longer periods of protection based on the life of the author, plus a certain number of years after his death, have become traditional.

A man ought to have the same property in productions of his mind as in those of his hands. It is in the interests of the public that valuable literature should be encouraged, and the great and good authors will benefit most from long periods of protection because such works have a lasting public. Authors are stimulated to create by the need to provide for their dependants; long periods of protection ensuring the provision of financial support to their descendants even after their death will, therefore, encourage them in their chosen profession. The author has expenses and works without being assured of certain and immediate returns; his heirs should be in a position to recoup his investment. Likewise, publishers need time to recover their investment costs; long terms are necessary because publishers usually offset losses on less popular books by their profits on the more successful. This is especially true of serious works of literature and music in respect of which investments are only recovered on a long-term basis. Long terms of protection strengthen the negotiating position of the copyright owner, thus ensuring him of a higher income while he is still alive.

The author and his descendants should be able "to protect the public from the evil of garbled editions" of his books. "It is to the public advantage that works of literature should be protected from those whose habit is to mutilate or misapply them, and that the authors' representative and one publisher should have power and interest to do so" ${ }^{21}$ 
Finally, uniformity (which in effect means harmonisation upwards) of terms of protection at the international level provides advantages in facilitating world-wide dissemination of works. As Ricketson points out:

national differences in term ... will lead to various disadvantages. Rights owners will be uncertain as to the duration of their rights in different countries and it will be expensive to monitor this. Third parties will also be under a similar burden. Furthermore, there may be distinct imbalances created in international trade, where a work can be exploited freely in one country but not in another where it is still protected. ${ }^{22}$

The arguments against long periods of protection include the following, most of which were eloquently phrased by Macaulay in the famous debate in the UK House of Commons in 1841, to which reference has already been made. The same arguments obviously gain additional strength in the case against perpetual rights. A strong case against such rights was argued also by Renouard in his treatise published two years previously. ${ }^{23}$

It is doubtful that authors are inspired to create by the possibility of their grandchildren obtaining remuneration for their efforts: "But an advantage that is to be enjoyed more than half a century after we are dead, by somebody unborn, by somebody utterly unconnected with us, is really no motive to action." ${ }^{24}$ The descendants of the author may not be his chosen heirs; the author should be free to dispose of his property as he sees fit. Authors thus do not obtain greater motivation from a sixty year period of protection than from a twenty year period. Moreover, long periods of protection benefit not the individual author but his publisher to whom the rights in his works are more than likely to have passed before his death.

Long terms of protection "inflict grievous injury on the public, without conferring any compensating advantage on men of letters". ${ }^{25}$ The publisher will not give appreciably more for a copyright of sixty years than for one of twenty. Taste and fashion in literature and the arts change and very few books have a life of more than a few years. "Such is the inconstancy of the public taste, that no sensible man will venture to pronounce, 
with confidence, what the sale of any book published in our days [1841] will be in the years between 1890 and 1900." 26

As Chafee observed: "The publisher must have always shaped his lump sum offer according to his expectations of sales within the first few years of the copyright. That is when he makes his killing.... Good publishing accounting writes off all books within three years after publication as no longer an asset ". ${ }^{27}$

Here the US experience of the copyright renewal scheme, in force until the 1976 Act, provides evidence in support of Macaulay's thesis. Evans tells us that, in 1949, only eleven per cent of original copyrights were renewed for a further term after the expiration of the initial term of 28 years, suggesting that this provided pertinent evidence that the longer full-term was not much of an inducement to either original creation or publication. ${ }^{28}$ In a more recent study of the same subject undertaken by Barbara Ringer in 1960, she found that on average only 15\% of copyright owners saw any need to renew their copyright for a further term. ${ }^{29}$

Long terms are contrary to the public interest in that they enable descendants of the author and indeed publishers to either suppress works altogether or to limit access to and exploitation of works by demanding unreasonable royalties or imposing various restrictive conditions on their publication or performance. Long terms encourage piracy because they represent an unacceptable monopoly, which burdens the user with high prices, and thus leads to disrespect for the law.

Long periods of copyright protection lead to difficulties in identifying the successors in title of the original authors to whom application should be made for permission to reproduce the work, and are thus contrary to Chafee's sixth ideal of convenience. As Ricketson points out, "this is a concern to all users of copyright material, but the problems of educationalists, librarians, historians and performers probably loom largest in this respect". ${ }^{30}$ 
The problem with the issue of duration as Ricketson suggests is that "There has been little sustained discussion of the economic, social and cultural issues involved, and the steady trend towards longer terms has remained largely unquestioned". ${ }^{31}$

In 1992, Ricketson proposed that national and international studies should be carried out to seek to establish on a factual basis what the appropriate term for copyright protection should be. He called for such studies also to take account of the fact that copyright protection embraces many different subjectmatters, and while there may be a case for long periods of protection for certain categories of works, this may not be so for all works. The case of computer programs, to take an example, is one where increasing the term of protection would seem inappropriate in view of the short useful life of such works.

It is regrettable that Ricketson's proposal was disregarded by the European Commission. Requests for a study of the justifications for an increase in the term of protection in the context of the ongoing negotiations concerning a possible Protocol to the Berne Convention have not been followed up either, presumably because the issue has been dropped from the agenda for the time being.

The increase in term in the $\mathrm{EU}$ is a fait accompli. However, before the USA and other Member States of the Berne Union, or of the World Trade Organisation as regards any future review of the TRIPS Agreement, adopt a minimum term of 70 years p.m.a. for the protection of literary, musical and artistic works, they would be wise to adopt Ricketson's proposal. The limitation on the duration of protection is imposed in the public interest in order to provide the public with free access to copyright works as soon as possible and to promote the widest possible dissemination of such works for the benefit of the public. To extend the term of protection without having first ascertained the likely benefits and disadvantages to be derived therefrom on the basis of factual evidence and discussion of the public policy issues involved is not in the best interests of the public at large. 
On the subject of duration, the last word may be left to Dr. Johnson:

Were an author's right in his book to be perpetual, no book, however useful, could be universally diffused among mankind, should the proprietor take it into his head to restrain its circulation. For the good of the world, therefore, whatever individual work has once been created by an author, and issued out by him, should be understood as no longer in his power, but as belongiong to the publici at the same time, the author is entitled to an adequate reward. This he should have by an exclusive right to his work for a considerable number of years. ${ }^{32}$

\section{Exceptions to Protection}

Chafee's fifth ideal was that the protection given the copyright owner should not stifle independent creation by others. Thus, other people should be able to use the work in the sense that there is no monopoly in the ideas or facts contained therein but only in the form in which they are expressed. This ideal is a well-established principle of copyright legislation. "The limitations on copyright are necessary to keep the balance between two conflicting public interests: the public interest in rewarding creators and the public interest in the widest dissemination of their works, which is also the interest of the users of such works". ${ }^{33}$

In determining the scope of such exceptions, it is incumbent on the state to strike a fair balance between the interests of the authors on the one hand and those of the public on the other hand. "Limitations on the author's exclusive right may be imposed in order to facilitate the work's contribution to the intellectual and cultural enrichment of the community. However, the limitations must not be such as to dampen the will to create and disseminate new works".$^{34}$

\section{Free Fair Use}

The international copyright conventions and national laws permit limited free use of protected works in certain special cases in the public interest. As we have seen in Part II, at national 
level these limitations are prescribed by statute but the extent thereof has given rise to abundant case law in Germany, the UK and the USA. The exceptions permitted by the Berne Convention include free use of public speeches, lectures and speeches in legal proceedings; use of short excerpts by way of quotation or illustration for teaching (in such cases, the use must be compatible with fair practice and justified by the purpose); use justified in connection with the reporting of current events; use solely for the purposes of private study and research; and, finally, reproduction for 'personal' or 'private' use. ${ }^{35}$

In the UK and the USA, according to the doctrine of 'fair dealing' or 'fair use', the copyright owner may not object to minor borrowings from his protected work. It is the courts which have to decide whether copying for any particular purpose is fair dealing or not, in the light of the particular circumstances. The case law on these subjects has been described above.

\section{Non-Voluntary Licensing Systems}

Limitations may also take the form of statutory or compulsory licences, according to which, subject to certain conditions including the payment of equitable remuneration, a work may be used without the authorisation of the author. Such limitations are permitted by the Berne Convention for the right of reproduction, the right of broadcasting and the right of cable distribution. ${ }^{36}$ Under such schemes, the right owner loses control of his work; he cannot prevent its use. In a statutory licence scheme, the amount of the remuneration is laid down by statute. In the case of a compulsory licence, the right owner is entitled to negotiate with the user to fix the terms of the use, including the amount of the equitable remuneration. If the parties do not agree, the amount of remuneration is fixed by government authority, often a special government-appointed body or tribunal. As regards the choice between a statutory licence and a compulsory licence, the German Federal supreme Court has suggested that: 
There should be no limitations on copyright which serve merely the financial interests of individual users of works. One must also ensure that a limitation imposed in the public interest does not lead to the unjustified advancement of private commercial interests of users. In this dilemma, it seems appropriate to control merely the author's power to forbid but to leave him with the right to claim an equitable reward for the use of his work. ${ }^{37}$

The rationale for these licensing schemes is that they represent the most practical means of exercising rights in cases where it is impossible for the user to negotiate with all the right owners involved, for example, in the case of broadcasting or cable distribution, and that it is in the public interest to afford maximum access by the user to copyright material.

A comparatively new form of limitation imposed by statute on the exclusive rights of authors, again designed to facilitate the exercise of such rights and access by the user, is the grant of rights subject to the condition that such rights be exercised through a representative collecting society. This is the solution, for example, adopted by all laws providing for remuneration to be paid in respect of private copying to authors, producers of phonograms and performers. It is recognised that in this particular case individual collection would be impossible in practice. EU Directives in the field of copyright and related rights have opted for this solution as regards the rights of authors and performers to equitable remuneration for rental ${ }^{38}$ and generally in the case of cable distribution. ${ }^{39}$

\section{Private Use and Modern Technology}

Modern technical developments have put the generally recognised exception to protection which permits reproduction of works for limited and defined purposes under strain. The general public now has the means to copy works cheaply and easily for private and educational use. Under Art. 9(2) of the Berne Convention, exceptions to the right to authorise or prohibit the reproduction of works are only permitted in national legislation, "provided that such reproduction does not conflict with a normal exploitation of the work and does not unreasonably prejudice the legitimate interests of the author". These two rules are cumulative, both having to be fulfilled before reproduction is 
allowed. "In cases where there would be serious loss of profit for the copyright owner, the law should provide him with some compensation", such as, for example, a system of compulsory licensing with equitable remuneration. ${ }^{40}$

The exceptions permitted by the Berne Convention and reproduced in many legislations were framed either before the advent of modern reproduction techniques or, at the least, before the use of offset printing, the photocopier and audio and video recording machines became as widespread as it is now. The availability of these new machines has caused two major new uses of works, known respectively as 'reprography', as regards the copying of printed matter and 'private copying' or 'home taping' as regards recording of sound recordings, film and video. These practices are both consequences of technical progress and pose closely related, although not identical, legal problems. ${ }^{41}$ The main difference is that private copying is the copying of copyright material for personal use by a private individual in the home, whereas the bulk of photocopying is done by institutions and offices and much of what is copied is non-copyright material. Moreover, while vast numbers of private individuals have audio and video reproduction equipment at home, they do not yet possess photocopying machines for personal use. Thus, while private copying is a problem caused in the main by private individuals, reprography is a problem caused by institutions, and especially educational institutions.

It is now generally recognised that copying of this kind made possible by modern technology does not represent a normal exploitation of the work and does unreasonably prejudice the interests of the author. As a result, copyright laws are slowly being adapted to the new realities and, for example, introducing legislation to provide at least for remuneration to be paid to right owners with respect to these new uses of their works.

Other traditional exceptions, such as those relating to use for educational purposes, also involve conflicts of interest between private interests as represented by right owners, on the one hand, and public interests represented by the state on the other. 
Again, the state is called on to strike a balance between the interests of the copyright owners and those of the public and, in so doing, in the modern world, the state should have regard to technical developments and should not lightly set aside the individual rights of creators.

In the 1990s, the digital revolution has compounded these problems and the world is entering a new communications era, that of the Information Society ${ }^{42}$, made possible by the new Global Information Infrastructure currently in the course of construction, combining computer, telephone, satellite and cable technologies. All kinds of works, including multi-media works ${ }^{43}$, recorded in digital form and therefore capable of perfect-quality reproduction, are now beginning to be distributed on a worldwide scale over the emerging Information superhighways, the first manifestation of which is the Internet ${ }^{44}$.

As computers plug into the global net and so-called cyberspace, the physical containers in which we are used to seeing information bottled up -- like floppy discs and CD Roms -- may become obsolete. Once that happens, all products of the information age, from books to films to computer programs, will exist as speeding electrons darting around the world on the computer net. Where do we put the copyright turnstile on the global computer network in order to charge users and copiers? ${ }^{45}$

Governments and right owners are struggling to seek ways to keep pace with these developments and to ensure that the use of copyright works over the Internet and other such information systems is monitored and controlled. In this context, exceptions to copyright protection permitting free copying for private use need to be reassessed and the copyright system needs to evolve to secure adequate reward to right owners for use of their works in these new information systems.

The new means of reproduction and communication made possible by new technology have given rise to claims -- supported by consumer groups -- that the general public should be entitled to take full advantage thereof, regardless of the rules of copyright. Kerever has described this argument as follows:

New communication techniques make it possible for programs to be distributed instantaneously anywhere, and for recorded programs to be appropriated by individuals. The public has the right to benefit fully 
from these techniques, especially since they are used for the dissemination of information and culture. The legitimate demands of the public - in other words the general interest - are not done justice if each of the many uses of one and the same work is subject to the authorisation of a holder of rights. What makes the obstacle all the more formidable is that the right asserted is exclusive, monopolistic and discretionary, and that each program is made up of several protected works to which a complex web of intertwined rights is applicable....

This is the political challenge facing the law-maker who seeks to maintain the balance between the interests of creators and the disseminators of their works, on the one hand, and the interest of the public in access thereto, on the other. As stewart points out :

Even under the Berne Convention, each member country has to decide what the legitimate interests of the author are, whether the prejudice of these interests, which is inevitable, is reasonable or unreasonable, and what amounts to a normal exploitation of the work, which must be safeguarded. Fair dealing must always be a matter of degree. ${ }^{47}$

\section{The Exercise of Rights}

Chafee's sixth ideal of copyright is that the legal rules thereof should be convenient to handle. He remarked: "The rules should be certain, readily understood, not unduly complicated, as easy as possible to apply", to facilitate inter alia the avoidance of litigation.

The lawyers who advise authors, publishers, and other business men in drafting contracts and other transactions should be able to ascertain the rights of the parties and protect those rights with assurance. To require officials, judges, and lawyers to work with a statute which is intricate and leaves many important points unsettled is like asking an engineer to do his calculations with a warped and illegible sliderule.

In some respects, the rules of copyright meet this ideal. According to the Berne Convention, copyright protection is automatic and arises free from all formalities as soon as the work is created. As a matter of domestic law, a country is free to subordinate the existence or exercise of rights to formalities, such as deposit of copies with national libraries, registration, etc., but outside the country of origin the author is fully protected by the Berne Convention. ${ }^{49}$ This is obviously 
of great benefit not only to the right owner but also to the public, since to determine anywhere in the world whether a work is protected is a comparatively simple task.

Some of the exceptions and limitations on exclusive rights referred to above have been adopted by governments in response to the needs, interests and the convenience of the public. It would be clearly burdensome for the writer of an essay to have to clear the copyright in every quotation used. The difficulty of clearing the rights of authors long dead with their successors in title is one practical restraint on increasing terms of protection. Systems of non-voluntary licensing have also been introduced for the sake of convenience in order to facilitate the exercise of rights.

Another extremely important aspect of the administration of copyright, which meets Chafee's ideal of convenience, is the role of the collecting societies. In fact, regardless of whether nonvoluntary licensing systems exist or not, the need to negotiate with the various categories of right owners does not normally present problems to the user because of the existence of representative collecting societies which are well placed to represent their members in negotiations with all potential users of their works. ${ }^{50}$

Collective administration through such societies operates worldwide. Although the precise nature, representation and practices of collective licensing bodies vary from country to country, collective administration of copyrights by licensing bodies is standard practice. Such collecting societies are generally recognised as being the best means of protecting the right owners' interests, on the one hand, while facilitating the ease of access of copyright protected works to the consumer, on the other hand. Indeed, given the emergence of secondary mass usage by means of new uses such as reprography, private copying of sound and audiovisual recordings, satellite broadcasting, cable distribution, rental of phonograms and videograms, storage of protected works in data bases, and the use of computer technology to digitise and store works in combination with the new 
distribution and communication technologies mentioned above, the need for collective licensing bodies has become even more acute. It would be idealistic and impracticable to expect owners of exclusive rights to be able to control such exploitation on an individual basis and likewise to force users to negotiate with individual right owners.

Collective administration of copyrights serves two principal purposes:

(ii) to provide a service to users by facilitating access to copyright works and making it possible for users to comply with their obligations under the law to obtain licences for the use of copyright works.

There is a general consensus today that such collective administration bodies provide the best available mechanism for licensing and administering copyrights. The convenience offered by such bodies both to the owner and the user of copyright cannot be matched by any other means and, in their absence, in a totally free market, individual users and copyright owners would be at a serious disadvantage in negotiating and subsequently enforcing their rights. Thus, such bodies benefit right owners and users alike and operate in the public interest.

However, collecting societies are currently facing perhaps the greatest test of their history in facing the challenge of monitoring and securing reward for the use of their members' works on the Information Superhighways. Digital technology has the potential to facilitate the administration of rights. It offers scope for identifying, controlling access to, tracing, monitoring and rewarding all uses of works. It provides right owners for the first time with tools to control uses such as private copying. For the collecting societies, "the challenge is both to secure reward for use and also to ensure that securing that reward is for the users as fast, simple and painless as possible." ${ }^{51}$ To that end, the organisations and collecting 
societies representing the various copyright owners are establishing systems, which take advantage of digital technology to provide for digital identification of all works. Such digital identification is the first step in building an electronic system which will enable the use of copyright materials to be tracked, the users to be identified, recorded and charged in order for appropriate payment to be made for the use made. "The Answer to the Machine is in the Machine" . 52

As the 1995 US NII Report stated, such identification will be critical to the efficient operation and success of the NII.

Copyright management information will serve as a kind of license plate for a work on the information superhighway, from which a user may obtain important information about the work. The accuracy of such information will be crucial to the ability of consumers to find and make authorised uses of works on the NII. Reliable information will also facilitate efficient licensing and reduce transaction costs for licensable uses of copyright works (both fee-based and royaltyfree). ${ }^{53}$

The Report recommended that to provide legislative back up for such systems, the following should give rise to criminal offences and penalties: the circumvention of copyright protection systems, the providing of false copyright management information, and the removal or alteration of copyright management information. ${ }^{54}$

There would appear to be an international consensus developing on the need for legislative back up of the kind recommended by the US NII Report. The Commission of the European Communities in its Green Paper on Copyright and Related Rights in the Information Society ${ }^{55}$ suggested that it may be advisable for the Community to act in order to make technical systems of identification and protection compulsory, on a harmonised basis, once they have been developed. ${ }^{56}$ At the international level, the issue is under discussion with a view to including specific provisions in the Protocol to the Berne Convention, New Instrument for the Protection of Performers and Producers of Phonograms and Possible Instrument for the sui generis Protection of Databases, currently being negotiated under the auspices of the World Intellectual Property Organisation (WIPO). 
The digital revolution and the unprecedented scope for new means of distribution promised by the future Global Information Superhighway has once more altered the balance between copyright owners and users. This is a clear case where the legislator is required to intervene to reestablish the balance and to take proper account in the law of the current technology. In doing so, however, the public interest in the dissemination of and access to works should not be lost sight of. As Vinje reminds us:

So far, the debate on anti-circumvention legislation ...has occurred in a relative atmosphere of specialists who have special interests. Policy-makers, who no doubt seek a balanced and fair approach, would be wise to reach out and involve a broader circle of those representing the public interest in the current debate... Even if representatives of the public interest are more difficult to find in the corridors of power in Brussels, Washington and Geneva than those advocating current anti-circumvention proposals, policy-makers have a duty to seek them out and listen to them carefully. In the end, perhaps legislators can devise a law that achieves the laudable purposes behind the existing proposals without threatening the public interest. ${ }^{57}$

The setting of limits to the rights afforded by copyright must be seen as a balancing process between the conflicting interests of the copyright owners and the users, a process which requires adjustment from time to time by the legislature and the courts in the light of new circumstances and methods of exploitation. In making such adjustments the law-maker should have regard to the public interest in seeking solutions which will: "safeguard, in a concern for equity and justice, the interests both of the intellectual creators and those that make lawful use of the works and thus render a fundamental service to both the author and the community at large". ${ }^{58}$ 
Ricketson, Ibid. at 777 .

Proposal for a Council Directive Harmonising the Term of Protection of Copyright and Certain Related Rights, COM (92) final-Syn 395, OJ EC No. C 92/6, 23 IIC 806 (1992). For a discussion of the proposal see von Lewinski, Silke, 23 IIC 785 (1992).

4 See Directive 93/98: [1993] O.J. L290/9.

5 The duration of the related rights of performers, producers of phonograms and films and broadcasting organisations were fixed at fifty years from the relevant starting point for the calculation of the term, ie the respective performance, fixation, transmission, lawful publication, or lawful communication to the public.

6 On 1 January 1995, Austria, Finland and Sweden joined the European Union.

7 Memorandum of the International Bureau of WIPO on Questions concerning a possible Protocol to the Berne Convention, Doc. $\mathrm{BCP} / \mathrm{CE} / \mathrm{I} / 3$, October 1991.

8 See Directive, Recital 10.

9 See Directive, Recital 11.

10 WIPO Memorandum, Ibid., para. 159.

11 Extension of the duration of the protection of works under the Berne Convention, other than photographic works, was dropped from the list of topics to be covered by the Committee of Experts on a Possible Protocol to the Berne Convention as from its third session, following a decision of the Assembly of the Berne Union on September 19, 1992 .

Von Lewinski, op. cit. at 788-9.

OJ 1992 C $287 / 53$.

Cornish W.R., Intellectual Property, 13 Yearbook of European Law (1994) 485 at 489 et seq..

15 Report of the Committee of Experts on a Possible Protocol to the Berne Convention for the Protection of Literary and Artistic Works, second session, Geneva, 10 to 18 February 1992, paras. 147 to 160.

Ricketson, op. cit. at 753 .

Ricketson, Sam, Duration of Term of Protection Under the Berne Convention, 1991 Copyright 88.

The major advantage of a term post mortem over a fixed term after publication is that the term ceases at one and the same time with respect to all the works of the author. A fixed term of a period of years calculated from the date of publication was strongly advocated, however, inter alia, by Pouillet, op. cit. para. 137. This was, of course, also the system of the USA until 1 January 1978 and remains the system for calculating the term of protection of certain categories of works protected by copyright or related rights such as films and phonograms.

19 Macaulay, Hansard, Vol. 56, 5 February 1841, at 365.

Ricketson, op. cit., n. 1 supra; see also on this subject Evans, Luther, op. cit.; Masouyé, Claude, Towards a Prolongation of the General Duration of Protection, XXIV RIDA 93 (1959). 
Morgan, Charles, The House of Macmillan, (London, Macmillan, 1944), at $174-177$.

Ricketson, Sam, op. cit., n. 1 supra, at 771.

It would seem likely that this argument will be put forward forcefully in the future by the EU Member States to promote a general increase of the term of protection to 70 years p.m.a.. As has already been noted above (see page 78), the USA has been prompted by the EU Directive to introduce draft legislation to bring about such an increase. Should this occur, the combined pressure of the EU and USA for a general increase in the Berne convention and the TRIPS Agreement (a general review clause requires a review of the latter agreement two years after expiration of the transitional period following the entry into force of the WTO and at regular intervals thereafter (Article 71)) will be difficult to resist.

Renouard, op. cit. Vol. I, at 466 et seq.: "Making books more expensive in perpetuity, the complete destruction of any competition, for the present and for the future, would cause a mortal prejudice to social progress by slowing down the circulation of ideas. Not only society would suffer; the glory of the author and of his memory would be diminished; his dearest and most noble desire to see his ideas propagated would be compromised and betrayed."

Macaulay, op. cit. at 349.

Macaulay, Ibid. at 344.

Macaulay, Ibid. at 351.

Chafee, op. cit. at 721.

Evans, Luther, op. cit. at 10.

Ringer, Barbara, Renewal of Copyright, Study No. 1 (Vol. 1, Studies in Copyright, 1963), at 583 .

Ricketson, Sam, op. cit., n. 1 supra.

Ricketson, Ibid. at 783 .

Cited by Macaulay, Hansard, House of Commons debate, 6 April 1842, at 1384 .

Stewart, S.M., op. cit., Chapter 2, n. 13 supra, at 79.

Fabiani, Mario, A Profile of Copyright in Today's Society, 1982 Copyright 154 .

Berne Convention, Paris Act 1971, Articles $2^{\text {bis }}(1)$ and (2), $9(2)$, $10^{\text {bis }}(1),(2)$ and (3).

Berne Convention, Paris Act 1971, Articles $11^{\text {bis }}(2)$ and $13(1)$.

17 BGHZ 266-278 - Tonband.

Article $4(3)$ and (4) of the Rental Right Directive, see Chapter 4, n. 70 supra.

Article 9 of the Cable and Satellite Directive, see Ibid.

Masouyé, Claude, Guide to the Berne Convention (WIPO, 1978), at 56. 
41 For more information on these subjects see Davies, Gillian \& Hung, Michèle, op. cit., on private copying; and Neumann, Till, Urheberrecht und Schulgebrauch (115 UFITA 1994), on reprography.

42 The House of Lords Select Committee on Science and Technology in its report on the 'Information Society: Agenda for Action in the UK' has defined the 'Information Superhighway' as meaning "a publicly accessible network capable of transferring large amounts of information at high speed between users". The principle feature distinguishing a superhighway from existing telecommunications networks is that it should be capable of handling the two-way delivery of text, pictures, sound and video (ie multimedia). HL Paper 77, Session 1995-96, 5th. Report, July 1996, para. 1.1.

43 Multimedia works have been defined by the EU as being "combinations of data, text, sound, graphics, animation, still and moving images, stored in digital form and interactively accessible". See council Decision of 20 May 1996 adopting a multiannual Community programme to stimulate the development of a European multimedia content in the emerging information society (INFO 2000), Article 1.

44 "The Internet is a global network of computers linked mainly via the telephone system and the academic, research and commercial computing networks. The Internet is a fledgling superhighway network which is limited by the rate at which the network components can transmit and handle data. The Internet is not a genuine superhighway because it does not offer the basic capability of two-way real-time video transmission and interactivity. It is, however, widely available and highly functional as an information exchange and electronic mail service. The Internet also provides a useful prototype from which a full information superhighway might evolve. Part of that evolution has been the development of a user-friendly interface in the form of the world wide Web (WWW). The WWW allows access to a global network of computers by millions of people with no formal training in computer technology". Ibid., paras. 1.8 and 1.9 .

45 McCarthy, J. Thomas, Intellectual Property-America's Overlooked Export, 28 Intellectual Property L. Rev. (1996) 315.

46 Kerever, André, Reflections on the Future Development of Copyright, 1983 Copyright 373 .

47 Stewart, S.M., op. cit. at 80.

48 Chafee, op. cit. at 514.

49 Masouyé, op. cit. at 33.

50 See also Davies, Gillian, The Public Interest in Collective Administration of Rights, 1989 Copyright 82 .

51 Clark, Charles, The Copyright Environment for the Publisher in the Digital World, International Publishers' Association, March 1996. See also Vinje, Thomas C., A Brave New World of Technical Protection Systems: Will there Still be Room for Copyright? [1996] 8 EIPR 431.

clark, op. cit., at 20 .

53 NII Report, see Chapter 5, n. 33 supra, at 235.

54 Ibid, Appendix 1 - Proposed Legislation, Section 4, paras. 1201 and 1202 . 
56 Ibid., at 82 .

57 Vinje, op. cit., at 432 and 440 .

58 Fabiani, M., op. Cit. at 156. 
Chapter 11: Conclusions

Consider what you think justice requires and decide accordingly

Lord Mansfield

In the course of this study, attention has been directed to the public interest in the copyright system. An objective definition of the public interest in relation to copyright was suggested in 1981 by Barbara Ringer:

Given the political and cultural framework of a particular society and the economic resources at its disposal, the public interest is the aggregate of the fundamental goals that the society seeks to achieve for all of its members - not for a majority of its members or for any large and powerful group, but for all of the people within the society. Considered separately, a society's goals are often in conflict with one another, and in that case there must be a balancing. The art of government consists of achieving a harmonious rather than a destructive balance among conflicting goals. ${ }^{1}$

As we have seen, copyright provides the framework required to induce authors, artists and other creators, to create and to reward them for their work. It acts as an incentive for others to invest in the dissemination and exploitation of works for the ultimate benefit of the public. At its inception, copyright had as its purpose to provide a reward and stimulus to creators, and to encourage and improve learning and the progress of the arts and sciences. This study has shown that this was the common purpose of the first laws on the subject in the UK, USA and France. As Ginsburg concluded in her study of the origins of the copyright laws in France and the USA, "the first framers of copyright laws ... sought primarily to encourage the creation of and investment in the production of works furthering national, social goals". ${ }^{2}$

Copyright also serves the public interest in freedom of expression. By enabling the creator to derive a financial reward from his work, his artistic independence and right to create and publish according to his own wish and conscience is assured. Alternative methods of rewarding creators, such as patronage, whether by the state or by individuals, carry the risk of control or censorship. 
From the outset, it has also been seen to be in the public interest that copyright law should balance the interest of the copyright owner, on the one hand, and the interest of the public, in the sense of the user or consumer, on the other, in obtaining access as cheaply and easily as possible to information of all kinds. Although there is an apparent conflict between these two latter interests, the reality seems to be that any conflict is more imaginary than real. Protection of the rights of the creator of new works, in the form of a limited monopoly, and the possibility for the creator to derive profit from the exercise of those rights, has been shown to favour creativity, and ultimately, therefore, to be of more benefit to the consuming public than if there were no rewards based on copyright.

The temptation to think in terms of making desirable goods and services free to those who need them is deeply rooted in our culture, and may be seen already in the proposal that all loans should be made free of interest, as is suggested in Exodus 22, 25. It is still advocated at the present time in some Islamic countries. The problem is to find lenders in any such society. The situation is no different when it comes to deciding whether or not to protect works through copyright.

In 1989, the Organisation for Economic Cooperation and Development (OECD), in a research paper ${ }^{3}$ setting out the case for the effective international protection of intellectual property rights, concluded that the existence of such rights is a way to (a) encourage and safeguard intellectual and artistic creation; (b) disseminate new ideas and technologies as quickly as possible; (c) promote investment; (d) provide consumers with the fruits of creation and invention; (e) distribute these positive effects across all countries in a manner commensurate with their level of economic, industrial and technological development. The study also found that the existence of such rights has a positive economic effect. It encourages international trade; it supports the innovation process; it encourages investment and improves competition and, finally, has a positive effect on national creativity. 
Reference has already been made to the national studies carried out into the economic importance of copyright in the UK, USA, Germany and elsewhere, which have shown that the international average contribution of the copyright industries today may be estimated at over $3 \%$ of national income. ${ }^{4}$ The various national studies undertaken around the world have also shown the level of copyright-related employment to be up to $3.5 \%$ of the workforce. ${ }^{5}$ These studies also demonstrated that the development of the copyright-related industries during the $1980 \mathrm{~s}$ was more dynamic than for the economy as a whole and that this trend is continuing. The sector is growing faster than the rest of the economy, and new jobs are being created, whereas in other sectors of the economy jobs are being lost. As Marlies Hummel pointed out in a comparative analysis of the results of the various national economic studies available in 1990: "Thus, the economic importance of copyright industries with respect to the generation of income and jobs deserves to receive special attention." 6

The economic importance of copyright at a national level, allied to the vast increase in international trade involving intellectual property rights, has led to concern for greater respect for these rights at an international level. The US Government has estimated that the proportion of total world trade in goods protected by intellectual property has doubled since the Second World War." The International Chamber of Commerce, however, has calculated that up to $6 \%$ of total world trade is in products which infringe intellectual property rights. ${ }^{8}$

This being so, issues relating to intellectual property came to be regarded as new trade barriers.

In terms of international trade and GATT, the absence of adequate protection, or the existence of excessive protection, amount to trade barriers often having similar effects to quantitative restrictions or distortion of competition within a country... [And] upon addressing technical barriers to trade mainly in the Uruguay Round, issues relating to intellectual property were increasingly felt as a third generation of trade barriers. Insufficient protection not only frustrated and nullified advantages and market access in the country concerned. It also distorted competition in third markets.

It is in this context that international measures to control trade in counterfeit goods were incorporated in the Agreement on 
Trade Related Aspects of Intellectual Property (the TRIPS Agreement) adopted in 1993, in order to counter increasing problems of counterfeiting and piracy originating, in particular, in newly industrialised countries throughout the world.

Works protected by copyright represent a significant proportion of this international trade in addition to its economic importance at national level. It is crucial therefore for governments to recognise that they have an obligation to foster the creation of intellectual works and that a basic precondition for the continued success of creators and the copyright-related industries is appropriate and up-to-date copyright legislation.

Copyright exists to encourage and protect creativity. In an economic sense, too few resources will be devoted to the production of creative "works" if the creator is subsequently unable to exploit this creativity, by earning a sufficient return on the effort and investment expended in producing the work. ${ }^{10}$

Governments, therefore, should have a positive 'copyright policy', the aims of which should be to keep their copyright laws continually under review, so as to adapt them quickly to the changing environment and the challenges posed by rapid technological change, and to maintain a balance between the interests of creators, on the one hand, and those of the public, on the other, thus ensuring the protection of both individual and collective interests. Jacques Lang expressed the problem succinctly in his exposé des motifs presenting the bill that subsequently became the 1985 French Copyright Law to Parliament. Speaking of the need to introduce related rights for the first time into French law, he remarked: "It is in this field that there is the most acute need to legislate. It is a question of conferring rights ... in order to enable [the beneficiaries] to master the economic and social consequences of the rapid development of new means of communication without however obstructing their use." 11

There would be wisdom in keeping in mind Chafee's six ideals when contemplating such a copyright policy. Chafee suggested that: 
The law should seek to attain, so far as practicable, the six ideals I have described: complete coverage for all intellectual and artistic creations...; a monopoly against all forms of reproduction; international protection; absence of excessive protection for the monopoly; refusal to stifle independent creation; and legal rules convenient to handle. "12

Chafee admitted that the mere formulation of general principles would not solve all problems. Nevertheless, he added: "Yet general principles will help a good deal. We can keep aiming at them. If we fall short of them, it is worth while to know that fact and then ask whether the failure is permanently necessary or is merely preservation of the inadequate work of past legislators." 13

Chafee's principles were propounded in 1945, but, as David Ladd has reminded us: "Copyright principles are eternal - or should be to those who care at all about human progress and freedom but the precise rules by which we achieve copyright's objectives must vary and may need substantial changes to meet substantially changed circumstances" ${ }^{14}$

From the beginning, the law of copyright has developed in response to significant changes in technology. Indeed, as we have seen, it was first introduced as a consequence of the invention of printing. The greatest challenge to the copyright system of the past 50 years has been to keep pace with the proliferation of new categories of creative works made possible by new technology and of the new uses of works resulting from the new communication media. Experience has demonstrated the need for copyright legislation to be adapted swiftly to new technology, and new uses of works. If government fails in this task, users and consumers come to believe that they have a right to free use of works. Subsequently, the entrenched interests they represent make the task of the law-maker in redressing the balance between the interests of the copyright owners and the public at large much more difficult. It is the law-maker who has the duty to evaluate the issues and the conflicting interests of the various, often warring factions within the interested parties, to consider what justice requires and to take the necessary hard decisions in the general public interest of society as a whole. This 
remains the principal challenge that the law-maker faces today in the field of copyright.

In 1996, this challenge is compounded by the risk that the legislative process will be overtaken by events in the light of the accelerating pace of technological innovation. While governments commission reports on the impact of the transmission of works in digital form over information superhighways ${ }^{15}$ and discuss in the various international fora concerned how to address the copyright issues involved ${ }^{16}$, the Internet is developing apace (it is currently being used by up to 50 million people ${ }^{17}$ ) and governments are putting into place the telecommunications networks for the Global Information Infrastructure. International cooperation and rules are of course essential for copyright interests to be adequately protected in the global marketplace but such cooperation by its nature takes time.

In order for modern copyright legislation to meet Chafee's three positive ideals, first complete coverage of new forms of works, second the single monopoly, i.e. the sole right to control all the channels through which a work or a fragment of a work reach the market, and third international protection, existing legislation and the international conventions need regular fine tuning.

The ideal of securing complete coverage of new forms of works under copyright legislation has not always been swiftly accomplished. Edison invented the art of recording sound in 1877 , for example, but sound recordings were given specific protection against unauthorised commercial reproduction by copyright or related rights law only in 1976 in the United States of America and 1985 in France. International protection under the Rome Convention for the Protection of Performers, Producers of Phonograms and Broadcasting Organisations, 1961, remains limited by the relatively small number of member states, 50 as of 1 october 1996. Another example is the case of computer programs, which have been generally accepted for the past twenty-five years as being capable of protection under national legislation and the Berne Convention as literary works. Specific protection to that 
effect under the law, however, has only gradually found its way into national laws (although the $1991 \mathrm{EC}$ Directive $^{18}$ on the subject has hastened the process for the member states of the European Union). Likewise it is only now in the context of the possible Protocol to the Berne Convention, presently under negotiation, that the question of international protection of computer programs as literary works is likely to be settled.

The intervals at which states have legislated in the past to bring copyright legislation up to date have arguably been too long. In the past century, taking as examples the four countries covered by this study, the United kingdom has undertaken major revisions of its legislation on only three occasions (1911, 1956 and 1988), the United States of America on two occasions, 1909 and 1976, France on two occasions, 1957 and 1985 and Germany also on two occasions, 1901 and 1965. Technical and international developments in the meantime have made regular and ever more frequent adaptation and revision of the most recent laws necessary, as has been seen above in Part II. The Berne Convention itself was last revised 25 years ago in 1971.

In adapting copyright legislation to technical and marketplace developments, as the US NII report stated:

Certain issues merely require an explanation of the application of the current law, and clearly are appropriately covered. Others present rights or limitations that clearly fit within the spirit of the law but the letter of the law is in need of clarification to avoid uncertainty and unnecessary litigation. Still others need new solutions.

Issues requiring explanation in the context of the Global Information Infrastructure include the question of multimedia works and the impact of digitisation of works. There appears to be consensus that multimedia works are not a new category of work but may be considered to be compilations or collections of works, and, as such, protected under national laws and the Berne Convention. ${ }^{20}$ Digital technology can record, store and communicate, throughout the world electronic marketplace, all existing works, whether originally expressed as the written word or as films, sound recordings, pictures, photographs and so on. 
However, the process of digitization of works does not create a new category of work; it merely constitutes the expression of copyright subject-matter in a different format. An example of an issue where the law requires clarification is the need to make it clear that the electronic transmission of works in a nonphysical format from computer to computer over telecommunications systems represents a communication to the public and is a protected act subject to the authorisation of the copyright owner, even if the transmission may be received at the convenience of an individual user in an on-demand service. In the same context, the letter of the law needs to be clarified to make it clear that copying protected works by means of down-loading audiovisual and printed matter from telecommunications networks is an act of reproduction subject to the exclusive reproduction right. Again, in this context, an example of a new solution required is legislation to provide a legal framework to promote and protect the copyright protection and management systems being developed to monitor, control and ensure payment for the use of copyright subject-matter on the information superhighways and referred to above in Chapter $10 .{ }^{21}$

Legislative proposals for change should meet certain general standards. In 1985 Kastenmeier and Remington ${ }^{22}$ put forward a political test for intellectual property legislation in the United States of America, which holds good today and is relevant to law-makers in all jurisdictions. They suggested that legislation should respond to specific problems and "at the outset the proponents of change should have the burden of showing that a meritorious public purpose is served by the proposed Congressional action". The change should be necessary, fair and practical. To discharge that burden, the proposed legislation would have to satisfy a four-fold political test.

First, the proponent of a new interest ought to show that the interest can fit harmoniously within the existing legal framework without violating existing principles or basic concepts. The proponent must further indicate whether fundamental aspects of current law, such as the term of protection and exclusive rights are compatible with the protection sought for the new interest...

Second, the proponent of a new intellectual property interest must be able to commit the new expression to a reasonably clear and satisfactory definition... 
Third, the proponent of change should present an honest analysis of all the costs and benefits of the proposed legislation. The proponent must show the difference between the status quo and the future contemplated by the legislation...

Fourth, any advocate of a new protectable interest should show in the record how giving protection to that interest will enrich or enhance the aggregate public domain. The aggregate public benefit should outweigh the proprietary gains which result from protection... ${ }^{23}$

Congress will attempt to recognise and balance the legitimate rights of producers, creators or copyright holders and the interests of the public. The legislator must attend to the voices of less powerful interests in order to achieve sound public policy. ${ }^{24}$ They suggest that Congress can safely move forward if the cost to the public of the monopoly is deemed to be less than the value to the public of the total benefits caused by the 1 aw. ${ }^{25}$

According to Chafee's third ideal, protection should be international. In 1996, this ideal takes on far greater significance than when it was first propounded in 1945. The world has become a much smaller place in the meantime. The international copyright system has grown dramatically: in 1945, the Berne Convention numbered 35 Member states, as of 1 October 1996 it had 119. The influence of the harmonisation programme of the European Union cannot be overlooked either by its member states or their trading partners. The TRIPS Agreement has highlighted the essential need for adequate protection of intellectual property in all countries which take part in the international trading system of the World Trade Organisation. Governments can therefore no longer pursue national copyright policies and consider legislation only as regards its domestic impact; they must take account also of the consequences of their domestic policies on other countries, on their bilateral and multilateral partners and on trade.

It is submitted, therefore, that the economic and cultural policies of states as expressed through copyright legislation should ensure that an adequate framework exists to provide "a proper balance based upon equity, fair competition and fair access and the public interest", ${ }^{26}$ and to ensure the level of investment required to take full advantage, for the benefit both of right owners and the public, of new means of communication and 
distribution of copyright works made possible by new technology. Such policies should keep uppermost the principle that, as this study has shown, the interests of the public in general are ultimately best served by safeguarding the interests of creators and giving them a level of protection sufficient to encourage them to continue to create.

In conclusion, this study has demonstrated that the roots of European and US copyright legislation shared a common approach and that such differences in copyright theory and practice as may have arisen in the past century should not be regarded as obstacles to future international copyright harmonisation.

In relation to authors' rights, for over a hundred years, the Berne Convention has evolved in such a way as to provide a bridge between the approaches of the common law and civil law systems in many respects. Differences in relation to such conditions of protection as the requirement of originality, formalities, ownership of rights and moral rights appear to be diminishing so far as authors' rights are concerned. While theoretical and even ideological differences have undoubtedly developed over the years as regards the objects of protection under authors' rights and copyright legal systems, and as regards the scope of that protection, the modern copyright legislation of the countries discussed in this study shows a remarkable harmony with respect to the categories of works protected and to the beneficiaries of such protection, whether such protection be by means of copyright, author's rights or related rights. In practical terms there has been a considerable convergence in the scope of the protection afforded under the common law and civil law systems. ${ }^{27}$

In the context of the present efforts to harmonise copyright and related rights legislation within the European Union and to find common solutions to new problems within the framework of the international copyright conventions, it is incumbent on the lawmaker to bear in mind Ginsburg's conclusion, already referred to, that: "There is in fact a rich tradition of copyright congruity upon which modern advocates of international copyright 
harmonization may draw to formulate mutually acceptable principles for the protection of works of authorship." ${ }^{28}$

It should be a priority, therefore, for all concerned to steer clear of theological debates about the respective merits of various national approaches and to seek solutions and an international framework which can accomodate both the common law and civil law approaches, thus building further bridges between the systems as traditionally the Berne Convention has done in the past.

Providing high levels of legal and technical protection of creative content will be one of the essential conditions to ensure the necessary climate for the investment needed for the development of the information society. Thus, there is a need for internationally recognised protection for the creators and providers of materials that will be disseminated over the Global Information Infrastructure. ${ }^{29}$ 
Ringer, Barbara, Authors' Rights in the Electronic Age: Beyond the Copyright Act of 1976, 1 Loyola Entertainment Law Journal 1 (1981).

2 See Ginsburg, Jane C., A Tale of Two Copyrights: Literary Property in Revolutionary France and America, 147 RIDA 131, 133 (1991).

3 Economic Arguments for Protecting Intellectual Property Rights, (Paris, Organisation for Economic Cooperation and Development, Trade Division, 1989). For a summary of the results of the study, see 2 Intellectual Property in Business, Issue 6, at 26 (1990).

Skilbeck, Jennifer, The Economic Importance of Copyright (London, International Publishers Association, 1988). See also the recent reports cited in Chapter 8 , nn. 6 to 9.

Humme1, Marlies, The Economic Importance of Copyright, UNESCO Copyright Bulletin, Vol. XXIV, No. 2, at 14 (1990).

Humme1, Ibid. at 21.

7 Slaughter, John, TRIPS: The GATT Intellectual Property Negotiations Approach their Conclusion, 11 EIPR 418 (1990).

Slaughter, Ibid.

Cottier, Thomas, The value and effects of protecting intellectual property rights within the World Trade Organisation, in ALAI Geneva study session 1994, Groupe suisse de l'ALAI et les auteurs, Berne 1994, at 16.

10 Price, T., op. cit., Chapter 8, supra n. 6.

11 Lang, Jack, 127 RIDA 6 (1986).

12 Chafee, op. cit., Chapter 1, n. 13 supra, at 515.

13 Chafee, Ibid. at 519.

14 Ladd, David, To Cope with the World Upheaval in Copyright, 1983 Copyright 289,294 .

15 See, for example, in addition to the US NII Report, cf. Chapter 5, n. 33 supra: Europe's Way to the Information Society, An Action Plan, Communication of the Commission to the Council and the European Parliament, (COM (94) 347 final) 19 July 1994; European Commission Green Paper on Copyright and Related Rights in the Information Society, (COM (95) 382 final) 19 July 1995; The Challenge of the Information Highway, Final Report of the Information Highway Advisory Council, Canada, 1995. Industrie Culturelle et Nouvelle Technique, Sirinelli report, Ministère de la Culture et de la Francophonie, Paris, 1994; Information Society: Agenda for Action in the UK, Report of the House of Lords Select Committee on Science and Technology, HL Paper 77, Session 1995-96, 5th. Report, July 1996.

In parallel with the discussions which have been taking place since 1993 in WIPO on a possible Protocol to the Berne Convention and on a possible new instrument for the protection of the rights of performers and producers of phonograms, WIPO has also held a series of Conferences: the WIPO Worldwide Symposium on the Impact of Digital Technology on Copyright and Neighbouring Rights, Harvard University, 1993; the WIPO Worldwide Symposium on the Future of Copyright and Neighbouring Rights, Paris, 1994; WIPO Worldwide Symposium on Copyright in the Global Information Infrastructure, Mexico City, 1995 . 
"The growth of the Internet has been the most astonishing technological phenomenon of the last decade of this century. In 1990 only a few academics had heard of it; now, anything up to $50 \mathrm{~m}$ people use it. In a year's time, that figure could be $100 \mathrm{~m}--\mathrm{so}$ far, the network's only constant has been that the number of people tapping into it has doubled every 12 months." Quoted from article "Why the Net should grow up". The Economist, 19 October 1996, at 15.

18 Council Directive 91/250/EEC of 14 May 1991 on the legal protection of computer programs (OJ EC NO. L122/42).

19 US NII report, op. cit. at 211.

20 Article 2, paragraph (5) of the Berne Convention provides: "Collections of literary or artistic works such as encyclopaedias and anthologies which, by reason of the selection and arrangement of their contents, constitute intellectual creations shall be protected as such, without prejudice to the copyright in each of the works forming part of such collections."

21 For a comprehensive account of these issues see the Basic Proposal for the Substantive Provisions of the Treaty on Certain Questions Concerning the Protection of Literary and Artistic Works to be considered by the forthcoming Diplomatic Conference on Certain Copyright and Neighbouring Rights Questions, to be held in Geneva from 2-20 December, 1996. On the impact of digital technology on copyright and related rights, see inter alia: Records of the WIPO Worldwide Symposium on the Impact of Digital Technology on Copyright and Neighbouring Rights, Harvard University, 1993, WIPO Publication No. 723 (1993); Christie, Andrew, Reconceptualising Copyright in the Digital Era, [1995] 11 EIPR 522; Davison, Mark, Geographical Restraints on the Distribution of Copyright Material in a Digital Age: Are they Justified? [1996] 9 EIPR 477; Dixon, Allen N. and Self, Laurie $C_{.}$, Copyright Protection for the Information Superhighway, [1994] 11 EIPR 465; Geller, Paul E., The Universal Electronic Archive: Issues in International Copyright, 25 IIC 54 (1994); Gendreau, Ysolde, Digital Technology and Copyright: Can Moral Rights Survive the Disappearance of the Hard Copy?, [1995] 6 ENT. LR 214 . olswang, Simon, Accessright: An Evolutionary Path for Copyright into the Digital Era? [1995] 5 EIPR 215; Samuelson, Pamela, Digital Media and the Changing Face of Intellectual Property Law, 16 Rutgers Computer and Technology Law Journal 323 (1990).

Kastenmeier, Robert $W$. and Remington, Michael J., The Semiconductor Chip Protection Act of 1984: A Swamp or Firm Ground? 70 Minnesota L. Rev. 417 (1985). Mr. Kastenmeier was at the time the Chairman of the House Committee on the Judiciary subcommittee on Courts, Civil Liberties and the Administration of Justice; Mr. Remington was Chief Counsel to the Committee. See also Kastenmeier, Robert $W$., The 1989 Horace S. Manges Lecture--"Copyright in an Era of Technological Change: A Political Perspective", 14 Colum.-VLA J.L. \& Arts, 1 (1989).

23 Kastenmeier and Remington, op. cit., at 440-441.

24 Kastenmeier, Robert W., op. cit., at 6 .

25 Kastenmeier and Remington, op. cit., at 442 .

26 Dworkin \& Taylor, op. cit. at 3. 
27 Cf. Davies, Gillian, The Convergence of Copyright and Authors' Rights - Reality or Chimera? 26 IIC 964 (1995) and Strowe1, Alain, Droit d'auteur et copyright. Divergences et Convergences. Etude de droit comparé (Brussels) 1993.

28 Ginsburg, op. cit., at 201.

29 Conclusions of the G 7 Ministerial Conference on the Global Information Society, Round-table meeting of business leaders, Brussels, February 1995. 


\title{
Appendices
}

\author{
UNITED KINGDOM
}

Statute of Anne 1709

\section{CAP XIX}

An Act for the Encouragement of Learning, by vesting the Copies of printed Books in the Authors or Purchasers of such Copies, during the Times therein mentioned.

I. Whereas Printers, Booksellers and other Persons have of late frequently taken the Liberty of printing, reprinting and publishing, or causing to be printed, reprinted and published, Books and other Writings, without the Consent of the Authors or Proprietors of such Books and Writings, to their very great Detriment, and too often to the Ruin of them and their Families: For preventing therefore such Practices for the future, and for the Encouragement of learned Men to compose and write useful Books; May it please your Majesty, that it may be enacted, and be it enacted by the Queen's most Excellent Majesty, by and with the Advice and Consent of the Lords Spiritual and Temporal, and Commons, in this present Parliament assembled, and by the Authority of the same, That from and after the tenth Day of April, one thousand seven hundred and ten, the Author of any Book or Books already printed, who hath not transferred to any other the Copy or Copies of such Book or Books, Share or Shares thereof, or the Bookseller or Booksellers, Printer or Printers, or other Person or Persons, who hath or have purchased or acquired the Copy or Copies of any Book or Books, in order to print or reprint the same, shall have the sole Right and Liberty of printing such Book and Books for the Term of one and twenty years, to commence from the said tenth Day of April, and no longer; and that the Author of any Book or Books already composed, and not printed and published, or that shall hereafter be composed, and his Assignee or Assigns, shall have the sole 
Liberty of printing and reprinting such Book and Books for the Term of fourteen Years, to commence from the Day of the first publishing the same, and no longer; and that if any other Bookseller, Printer or other Person whatsoever, from and after the tenth Day of April, one thousand seven hundred and ten, within the Times granted and limited by this Act, as aforesaid, shall print, reprint, or import, or cause to be printed, reprinted, or imported, any such Book or Books, without the Consent of the Proprietor or Proprietors thereof first had and obtained in Writing, signed in the Presence of two or more credible Witnesses; or knowing the same to be so printed or reprinted, without the Consent of the Proprietors, shall sell, publish, or expose to Sale, or cause to be sold, published or exposed to Sale, any such Book or Books, without such Consent first had and obtained, as aforesaid; Then such offender or offenders shall forfeit such Book or Books, and all and every Sheet or Sheets, being Part of such Book or Books, to the Proprietor or Proprietors of the Copy thereof, who shall forthwith Damask and make Waste Paper of them; and further, That every such offender or Offenders shall forfeit one Penny for every sheet which shall be found in his, her, or their custody, either printed or printing, published or exposed to sale, contrary to the true Intent and Meaning of this Act; the one Moiety thereof to the Queen's most excellent Majesty, her Heirs and Successors, and the other Moiety thereof to any Person or Persons that shall sue for the same, to be recovered in any of her Majesty's Courts of Record at Westminster, by Action of Debt, Bill, Plaint, or Information, in which no Wager of Law, Essoin, Privilege, or Protection, or more than one Imparlance shall be allowed.

II. And whereas many Persons may through Ignorance offend against this Act, unless some Provision be made, whereby the Property in every such Book, as is intended by this Act to be secured to the proprietor or proprietors thereof, may be ascertained, as likewise the Consent of such Proprietor or Proprietors for the printing or reprinting of such Book or Books may from time to time be known; Be it therefore further enacted by the Authority aforesaid, That nothing in this Act contained 
shall be construed to extend to subject any Bookseller, Printer, or other Person whatsoever, to the Forfeitures or Penalties therein mentioned, for or by Reason of the printing or reprinting of any Book or Books without such Consent, as aforesaid, unless the Title to the Copy of such Book or Books hereafter published shall, before such Publication, be entred in the Register Book of the Company of stationers, in such Manner as hath been usual, which Register Book shall at all Times be kept at the Hall of the said Company, and unless such Consent of the Proprietor or Proprietors be in like Manner entred as aforesaid, for every of which several Entries six Pence shall be paid, and no more; which said Register Book may, at all seasonable and convenient times, be resorted to, and inspected by any Bookseller, Printer or other Person, for the Purposes before-mentioned, without any Fee or Reward; and the Clerk of the said Company of stationers shall, when and as often as thereunto required, give a Certificate under his hand of such Entry or Entries, and for every such Certificate may take a Fee not exceeding six Pence.

III. Provided nevertheless, That if the clerk of the said Company of Stationers for the Time being, shall refuse or neglect to register, or make such Entry or Entries, or to give such Certificate, being thereunto required by the Author or Proprietor of such Copy or Copies, in the Presence of two or more credible Witnesses, That then such Person and Persons so refusing, Notice being first duly given of such Refusal, by an Advertisement in the Gazette, shall have the like Benefit, as if such Entry or Entries, Certificate or Certificates had been duly made and given, and that the Clerks so refusing, shall, for any such offence, forfeit to the Proprietor of such Copy or Copies the Sum of twenty Pounds, to be recovered in any of her Majesty's Courts of Record at Westminster, by Action of Debt, Bill, Plaint, or Information, in which no Wager of Law, Essoin, Privilege or Protection, or more than one Imparlance shall be allowed.

IV. Provided nevertheless, and it is hereby further enacted by the Authority aforesaid, That if any Bookseller or Booksellers, Printer or Printers, shall, after the said five and twentieth Day of March one thousand seven hundred and ten, set a Price upon, 
or sell, or expose to Sale, any Book or Books at such a Price or Rate as shall be conceived by any Person or Persons to be too high and unreasonable; it shall and may be lawful for any Person or Persons, to make Complaint thereof to the Lord Archbishop of Canterbury for the time being, the Lord Chancellor, or Lord Keeper of the Great Seal of Great Britain for the time being, the Lord Bishop of London for the time being, the Lord Chief Justice of the Court of Queen's Bench, the Lord Chief Justice of the Court of Common Pleas, the Lord Chief Baron of the court of Exchequer for the time being, the Vice Chancellors of the two Universities for the time being, in that Part of Great Britain called England; the Lord President of the Sessions for the time being, the Lord Chief Justice General for the time being, the Lord Chief Baron of the Exchequer for the time being, the Rector of the College of Edinburgh for the time being, in that part of Great Britain called Scotland; who, or any one of them, shall and have hereby full Power and Authority, from time to time, to send for, summon, or call before him or them such Bookseller or Booksellers, Printer or Printers, and to examine and enquire of the Reason of the Dearness and Inhauncement of the Price or Value of such Book or Books by him or them so sold or exposed to Sale; and if upon such Enquiry and Examination it shall be found, that the Price of such Book or Books is inhaunced, or any wise too high or unreasonable, then and in such case the said Archbishop of Canterbury, Lord Chancellor or Lord Keeper, Bishop of London, two Chief Justices, Chief Baron, Vice Chancellors of the Universities, in that Part of Great Britain called England, and the said Lord President of the Sessions, Lord Justice General, Lord Chief Baron, and Rector of the College of Edinburgh, in that Part of Great Britain called Scotland, or any one or more of them, so enquiring and examining, have hereby full power and Authority to reform and redress the same, and to limit and settle the Price of every such printed Book and Books, from Time to Time, according to the best of their Judgments, and as to them shall seem just and reasonable; and in case of Alteration of the Rate or Price from what was set or demanded by such Bookseller or Booksellers, Printer or Printers, to award and order such Bookseller and Booksellers, Printer and Printers, to pay all the Costs and Charges that the Person or Persons so complaining shall 
be put unto, by Reason of such Complaint, and of the causing such Rate or Price to be so limited and settled; all which shall be done by the said Archbishop of Canterbury, Lord Chancellor or Lord Keeper, Bishop of London, two Chief Justices, Chief Baron, Vice Chancellors of the two Universities, in that Part of Great Britain called England, and the said Lord President of the Sessions, Lord Justice General, Lord Chief Baron, and Rector of the College of Edinburgh, in that Part of Great Britain called Scotland, or any one of them, by Writing under their Hands and Seals, and thereof publick Notice shall be forthwith given by the said Bookseller or Booksellers, Printer or Printers, by an Advertisement in the Gazette; and if any Bookseller or Booksellers, Printer or Printers, shall after such settlement made of the said Rate and Price, sell, or expose to Sale, any Book or Books, at a higher or greater Price, than what shall have been so limited and settled, as aforesaid, then, and in every such Case such Bookseller and Booksellers, Printer and Printers, shall forfeit the Sum of five Pounds for every such Book so by him, her, or them sold or exposed to Sale; one Moiety thereof to the Queen's most excellent Majesty, her Heirs and Successors, and the other Moiety to any Person or Persons that shall sue for the same, to be recovered, with costs of Suit, in any of her Majesty's Courts of Record at Westminster, by Action of Debt, Bill, Plaint or Information, in which no Wager of Law, Essoin, Privilege, or Protection, or more than one Imparlance shall be allowed.

V. Provided always, and it is hereby enacted, That nine copies of each Book or Books, upon the best Paper, that from and after the said tenth Day of April, one thousand seven hundred and ten, shall be printed and published, as aforesaid, or reprinted and published with Additions, shall, by the Printer and Printers thereof, be delivered to the Warehouse keeper of the said Company of Stationers for the Time being, at the Hall of the said Company, before such Publication made, for the use of the Royal Library, the Libraries of the Universities of oxford and Cambridge, the Libraries of the four Universities in Scotland, the Library of Sion College in London, and the Library commonly called the Library belonging to the Faculty of Advocates at 
Edinburgh respectively; which said Warehouse keeper is hereby required within ten Days after Demand by the Keepers of the respective Libraries, or any Person or Persons by them or any of them authorized to demand the said Copy, to deliver the same, for the Use of the aforesaid Libraries; and if any Proprietor, Bookseller, or Printer, or the Warehouse keeper of the said Company of Stationers, shall not observe the Direction of this Act therein, that then he and they so making Default in not delivering the said printed Copies, as aforesaid, shall forfeit, besides the value of the said printed Copies, the Sum of five Pounds for every Copy not so delivered, as also the value of the said printed Copy not so delivered; the same to be recovered by the Queen's Majesty, her Heirs and Successors, and by the Chancellor, Masters, and Scholars of any of the said Universities, and by the President and Fellows of Sion College, and the said Faculty of Advocates at Edinburgh, with their full Costs respectively.

VI. Provided always, and be it further enacted, That if any Person or Persons incur the Penalties contained in this Act, in that Part of Great Britain called Scotland, they shall be recoverable by any Action before the Court of Session there.

VII. Provided, That nothing in this Act contained do extend, or shall be construed to extend to prohibit the Importation, Vending or Selling of any Books in Greek, Latin, or any other foreign Language printed beyond the Seas; any thing in this Act contained to the contrary notwithstanding.

VIII. And be it further enacted by the Authority aforesaid, That if any Action or Suit shall be commenced or brought against any Person or Persons whatsoever, for doing or causing to be done any Thing in pursuance of this Act, the Defendant in such Action may plead the General Issue, and give the special Matter in Evidence; and if upon such Action a Verdict be given for the Defendant, or the Plantiff become nonsuited or discontinue his Action, then the Defendant shall have and recover his full Costs, for which he shall have the same Remedy as a Defendant in any Case by Law hath. 
IX. Provided, That nothing in this Act contained shall extend, or be construed to extend, either to prejudice or confirm any Right that the said Universities or any of them, or any Person or Persons have, or claim to have, to the printing or reprinting of any Book or Copy already printed, or hereafter to be printed.

x. Provided nevertheless, That all Actions, Suits, Bills, Indictments or Informations for any offence that shall be committed against this Act, shall be brought, sued, and commenced within three Months next after such offence committed, or else the same shall be void and of none Effect.

XI. Provided always, That after the Expiration of the said Term of fourteen Years, the sole Right of printing or disposing of Copies shall return to the Authors thereof, if they are then living, for another Term of fourteen years. 
U.S.A.

\section{Copyright Act 1790}

CHAP. XV. - An ACt for the encouragement of learning, by securing the copies of maps, charts, and books, to the authors and proprietors of such copies, during the times therein mentioned.

SECTION 1. Be it enacted by the senate and House of Representatives of the United States of America in Congress assembled, That from and after the passing of this act, the author and authors of any map, chart, book or books already printed within these United States, being a citizen or citizens thereof, or resident within the same, his or their executors, administrators or assigns, who hath or have not transferred to any other person the copyright of such map, chart, book or books, share or shares thereof; and any other person or persons, being a citizen or citizens of these United States, or residents therein, his or their executors, administrators or assigns, who hath or have purchased or legally acquired the copyright of any such map, chart, book or books, in order to print, reprint, publish or vend the same, shall have the sole right and liberty of printing, reprinting, publishing and vending such map, chart, book or books, for the term of fourteen years from the recording the title thereof in the clerk's office, as is herein after directed: And that the author and authors of any map, chart, book or books already made and composed, and not printed or published, or that shall hereafter be made and composed, being a citizen or citizens of these United States, or resident therein, and his or their executors, administrators or assigns, shall have the sole right and liberty of printing, reprinting, publishing and vending such map, chart, book or books, for the like term of fourteen years from the time of recording the title thereof in the clerk's office as aforesaid. And if, at the expiration of the said term, the author or authors, or any of them, be living, and a citizen or citizens of these United States, or resident therein, the same exclusive right shall be continued to him or them, his or their executors, administrators or assigns, for the further term of fourteen years: Provided, he or they shall cause the title 
thereof to be a second time recorded and published in the same manner as is herein after directed, and that within six months before the expiration of the first term of fourteen years aforesaid.

$S E C$. 2. And be it further enacted, That if any other person or persons, from and after the recording the title of any map, chart, book or books, and publishing the same as aforesaid, and within the times limited and granted by this act, shall print, reprint, publish, or import, or cause to be printed, reprinted, published, or imported from any foreign kingdom or state, any copy or copies of such map, chart, book or books, without the consent of the author or proprietor thereof, first had and obtained in writing, signed in the presence of two or more credible witnesses; or knowing the same to be so printed, reprinted, or imported, shall publish, sell, or expose to sale, or cause to be published, sold, or exposed to sale, any copy of such map, chart, book or books, without such consent first had and obtained in writing as aforesaid, then such offender or offenders shall forfeit all and every copy and copies of such map, chart, book or books, and all and every sheet and sheets, being part of the same, or either of them, to the author or proprietor of such map, chart, book or books, who shall forthwith destroy the same: And every such offender and offenders shall also forfeit and pay the sum of fifty cents for every sheet which shall be found in his or their possession, either printed or printing, published, imported or exposed to sale, contrary to the true intent and meaning of this act, the one moiety thereof to the author or proprietor of such map, chart, book or books who shall sue for the same, and the other moiety thereof to and for the use of the United States, to be recovered by action of debt in any court of record in the United States, wherein the same is cognizable. Provided always, That such action be commenced within one year after the cause of action shall arise, and not afterwards.

SEC. 3. And be it further enacted, That no person shall be entitled to the benefit of this act, in cases where any map, chart, book or books, hath or have been already printed and 
published, unless he shall first deposit, and in all other cases, unless he shall before publication deposit a printed copy of the title of such map, chart, book or books, in the clerk's office of the district court where the author or proprietor shall reside: And the clerk of such court is hereby directed and required to record the same forthwith, in a book to be kept by him for that purpose, in the words following, lgiving a copy thereof to the said author or proprietor, under the seal of the court, if he shall require the same.) "District of ... to wit: Be it remembered, That on the ... day of ... in the ... year of the independence of the United States of America, A.B. of the said district, hath deposited in this office the title of a map, chart, book or books, (as the case may be) the right whereof he claims as author or proprietor, (as the case may be) in the words following, to wit: [here insert the title] in conformity to the act of the Congress of the United States, intituled 'An act for the encouragement of learning, by securing the copies of maps, charts, and books, to the authors and proprietors of such copies, during the times therein mentioned.' C. D. clerk of the district of -.-." For which the said clerk shall be entitled to receive sixty cents from the said author or proprietor, and sixty cents for every copy under seal actually given to such author or proprietor as aforesaid. And such author or proprietor shall, within two months from the date thereof, cause a copy of the said record to be published in one or more of the newspapers printed in the United States, for the space of four weeks.

$S E C$. 4. And be it further enacted, That the author or proprietor of any such map, chart, book or books, shall, within six months after the publishing thereof, deliver, or cause to be delivered to the secretary of state a copy of the same, to be preserved in his office.

SEC. 5. And be it further enacted, That nothing in this act shall be construed to extend to prohibit the importation or vending, reprinting or publishing within the United States, of any map, chart, book or books, written, printed, or published by any person not a citizen of the United States, in foreign parts or places without the jurisdiction of the United States. 
SEC. 6. And be it further enacted, That any person or persons who shall print or publish any manuscript, without the consent and approbation of the author or proprietor thereof, first had and obtained as aforesaid, (if such author or proprietor be a citizen of or resident in these United States) shall be liable to suffer and pay to the said author or proprietor all damages occasioned by such injury, to be recovered by a special action on the case founded upon this act, in any court having cognizance thereof.

SEC. 7. And be it further enacted, That if any person or persons shall be sued or prosecuted for any matter, act or thing done under or by virtue of this act, he or they may plead the general issue, and give the special matter in evidence.

APPROVED, MaY 31, 1790. 
FRANCE

\section{Le décret des 13-19 janvier 1791}

Relatif aux spectacles.

L'Assemblée nationale, oui le rapport de son comité de constitution décrète ce qui suit:

Article premier: Tout citoyen pourra élever un théâtre public et Y faire représenter des pièces de tous les genres, en faisant préalablement à l'établissement de son théâtre sa déclaration à la municipalité des lieux.

Article 2: Les ouvrages des auteurs morts depuis cinq ans et plus sont une propriété publique et peuvent nonobstant tous anciens privilèges qui sont abolis, être représentés sur tous les théâtres indistinctement.

Article 3: Les ouvrages des auteurs vivants ne pourront être représentés sur aucun théâtre public, dans toute l'étendue de la France, sans le consentement formel et par écrit des auteurs sous peine de confiscation du produit total des représentations au profit des auteurs.

Article 4: La disposition de l'article 3 s'applique aux ouvrages déjà représentés, quels que soient les anciens règlements.

Article 5: Les héritiers, ou les cessionnaires des auteurs seront propriétaires de leurs ouvrages durant l'espace de cinq années après la mort de l'auteur.

\section{Le décret des 19-24 juillet 1793}

La Convention nationale après avoir entendu son comité d'instruction publique, décrète ce qui suit: 
Article premier: Les auteurs d'écrits en tous genres, les compositeurs de musique, les peintres et dessinateurs qui feront graver des tableaux ou desseins, jouiront leur vie entière, du droit exclusif de vendre, faire vendre, distribuer leurs ouvrages dans le territoire de la République et d'en céder la propriété en tout ou en partie.

Article 2: Leurs héritiers ou cessionnaires jouiront du même droit durant I'espace de dix ans après la mort des auteurs.

Article 3: Les officiers de paix seront tenus de faire confisquer à la réquisition et au profit des auteurs, compositeurs, peintres ou dessinateurs ou autres, leurs héritiers ou cessionnaires, tous les exemplaires des éditions imprimées ou gravées sans la permission formelle et par écrit des auteurs.

Article 4: Tout contrefacteur sera tenu de payer au véritable propriétaire une somme équivalente au prix de trois mille (3.000) exemplaires de l'édition originale.

Article 5: Tout débitant d'édition contrefaite, si'il n'est pas reconnu contrefacteur, sera tenu de payer au véritable propriétaire une somme équivalente au prix de cinq cents exemplaires de l'édition originale.

Article 6: Tout citoyen, qui mettra au jour un ouvrage soit de littérature ou de gravure, dans quelque genre que ce soit, sera obligé d'en déposer deux exemplaires à la Bibliothèque Nationale ou au Cabinet des Estampes de la République dont il recevra un reçu signé par le bibliothécaire; faute de quoi, il ne pourra être admis en justice pour la poursuite des contrefacteurs.

Article 7: Les héritiers de l'auteur d'un ouvrage de littérature ou de gravure ou de toute autre production de l'esprit ou du génie qui appartient aux Beaux-Arts en auront la propriété exclusive pendant dix années. 


\section{GERMANY}

Preußisches Gesetz zum Schutze des Eigenthums an Werken der Wissenschaft und Kunst gegen Nachdruck und Nachbildung vom 11. Juni 1837

Wir Friedrich Wilhelm von Gottes Gnaden, König von Preußen ...

Damit dem Eigenthum an den Werken der Wissenschaften und Kunst der erforderliche Schutz gegen Nachdruck und Nachbildung gesichert werde, haben Wir Uns bewogen gefunden, die darüber bestehenden Gesetze einer Abänderung und Ergänzung zu unterwerfen, und verordnen demnach auf den Antrag Unseres Staats=Ministeriums und nach erfordertem Gutachten Unseres Staats=Raths, für den ganzen Umfang Unserer Monarchie, was folgt.

\$. 1 .

1. Schriften.

a) Ausschließendes Recht der Schriftsteller.

Das Recht, eine bereits herausgegebene Schrift, ganz oder theilweise, von neuem abdrucken oder auf irgend einem mechanischen Wege vervielfältigen zu lassen, steht nur dem Autor derselben oder denjenigen $z u$, welche ihre Befugniß dazu von ihm herleiten.

\section{\$. 2 .}

b. Verbot des Nachdruckes.

Jede solche neue Vervielfältigung, wenn sie ohne Genehmigung des dazu ausschließlich Berechtigten (\$.1.) geschieht, heißt Nachdruck, und ist verboten. 


\section{\$. 3 .}

c. Was dem Nachdruck gleich zu achten.

Dem Nachdruck wird gleich geachtet, und ist daher ebenfalls verboten, der ohne Genehmigung des Autors oder seiner Rechtsnachfolger bewirkte Abdruck

a. von Manuscripten aller Art;

b. von nachgeschriebenen Predigten und mündlichen Lehrvorträgen, gleichviel, ob dieselben unter dem wahren Namen des Autors herausgegeben werden oder nicht.

Dieser Genehmigung bedarf auch der rechtmäßige Besitzer eines Manuscripts oder einer Abschrift desselben (litt. a.), imgleichen nachgeschriebener Predigten oder Lehrvorträge (litt. b.).

\section{§. 4 .}

d. Was nicht als Nachdruck anzusehen.

Als Nachdruck ist nicht anzusehen

1) das wörtliche Anführen einzelner stellen eines bereits gedruckten Werkes;

2) die Aufnahme einzelner Aufsätze, Gedichte u.s.w. in kritische und literar=historische Werke und in Sammlungen zum Schulgebrauche;

3) die Herausgabe von Uebersetzungen bereits gedruckter Werke.

Ausnahmen.

Ausnahmsweise sind jedoch Uebersetzungen in folgenden Fällen dem Nachdruck gleich zu achten:

a. Wenn von einem Werke, welches der Verfasser in einer todten Sprache bekannt gemacht hat, ohne seine Genehmigung eine Deutsche Uebersetzung herausgegeben wird. 
b. Wenn der Verfasser eines Buches solches gleichzeitig in verschiedenen lebenden Sprachen hat erscheinen lassen, und ohne seine Genehmigung eine neue Uebersetzung des Werkes in eine der Sprachen veranstaltet wird, in welchen es ursprünglich erschienen ist. Hat der Verfasser auf dem Titelblatte der ersten Ausgabe bekannt gemacht, daß er eine Uebersetzung, und in welcher Sprache, herausgeben wolle, so soll diese Uebersetzung, wenn sie innerhalb zweier Jahre nach dem Erscheinen des Originals erfolgt, als mit dem Original gleichzeitig erschienen behandelt werden.

\section{§. 5 .}

e. Dauer des ausschließlichen Rechts.

Der Schutz des gegenwärtigen Gesetzes gegen Nachdruck und diesem gleichgestellte Handlungen ( $\$ \S .2$. und 3.) soll dem Autor einer Schrift, Predigt oder Vorlesung während seines Lebens zukommen.

\section{\$. 6 .}

Auch die Erben des Autors sollen denselben Schutz noch dreißig Jahre lang nach dem Tode ihres Erblassers genießen, ohne Unterschied, ob während seines Lebens ein Abdruck bereits erschienen ist oder nicht. Nach Ablauf dieser dreißig Jahre hört der Schutz dieses Gesetzes auf.

\section{§. 7 .}

In so fern von dem eigentlichen Nachdrucke die Rede ist ( $\$ \S$. 1. und 2.), setzt die in den $\S \S .5$. und 6. vorgeschriebene Dauer des Schutzes voraus, daß der wahre Name des Verfassers auf dem Titelblatte oder unter der Zueignung oder Vorrede angegeben ist. Eine Schrift, die entweder unter einem andern, als dem wahren Namen des Verfassers erschienen, oder bei welcher gar kein Verfasser genannt ist, soll funfzehn Jahre lang, von der ersten Herausgabe derselben an gerechnet, gegen den Nachdruck geschützt sein, und zur Wahrnehmung des Rechts auf diesen Schutz der 
Verleger an die Stelle des unbekannten Verfassers treten. Wird innerhalb dieser funfzehn Jahre der wahre Name des Verfassers von ihm selbst oder von seinen Erben, vermittelst eines neuen Abdruckes oder eines neuen Titelblattes für die vorräthigen Exemplare, bekannt gemacht, so wird dadurch dem werke der Anspruch auf die in den $\S \S .5$. und 6 . bestimmte Dauer des Schutzes erworben.

\section{§. 8 .}

Akademien, Universitäten, offentliche Unterrichts=Anstalten, gelehrte und andere erlaubte Gesellschaften genießen das ausschließende Recht zur neuen Herausgabe ihrer Werke dreißig Jahre lang.

\section{Diese Frist ist}

a. bei Werken, die in einem oder mehreren Bänden eine einzige Aufgabe behandeln, und mithin als in sich zusammenhängend betrachtet werden können, $z u$ denen namentlich auch die lexikalischen $z u$ zählen sind, von dem zeitpunkt ihrer Vollendung an,

b. bei Werken aber, die nur als fortlaufende Sammlungen von Aufsätzen und Abhandlungen über verschiedene Gegenstände der gelehrten Forschung anzusehen sind, von dem Erscheinen eines jeden Bandes an

zu rechnen.

Veranstalten jedoch die Verfasser besondere Ausgaben solcher Aufsătze und Abhandlungen, so kommen ihnen die Bestimmungen der §. 5. und 6 . zu statten.

\section{\$. 9 .}

f. Abtretung desselben.

Das ausschließende Recht zur Veröffentlichung und Verbreitung von Schriften, welches dem Autor und dessen Erben zusteht, kann von diesen ganz oder theilweise durch eine hierauf gerichtete Vereinbarung auf Andere übertragen werden. 


\section{\$. 10 .}

g. Strafen des Nachdrucks.

Wer das, den Autoren, ihren Erben oder Rechtsnachfolgern zustehende, ausschließende Recht dadurch beeintrăchtigt, daß er ohne deren Genehmigung von demselben Gebrauch macht, ist den Beeinträchtigten vollständig zu entschädigen verpflichtet und hat, außer der Confiscation der noch vorräthigen Exemplare, eine Geldbuße von funfzig bis tausend Thalern verwirkt.

\section{11}

War das Werk von dem Berechtigten bereits herausgegeben, so ist der Betrag der Entschädigung nach Beschaffenheit der Umstände auf eine dem Verkaufswerthe von funfzig bis tausend Exemplaren der rechtmäßigen Ausgabe gleichkommende Summe richterlich zu bestimmen, in so fern der Berechtigte nicht einen höheren Schaden nachzuweisen vermag.

\section{\$. 12 .}

Die confiscirten Exemplare der unrechtmäßigen Ausgabe sollen vernichtet oder dem Beschädigten auf sein Verlangen überlassen werden. Im letzten Falle muß sich jedoch der Beschädigte die von dem Verurtheilten auf diese Exemplare verwendeten Auslagen auf die Entschädigung anrechnen lassen.

\section{\$. 13 .}

Wer widerrechtlich vervielfältigte Werke wissentlich zum Verkauf hält, ist dem Beeintrăchtigten, mit dem unbefugten Vervielfältiger solidarisch, zur Entschädigung verpflichtet, und hat, außer der Confiscation, eine nach Vorschrift des \$. 10. zu bestimmende Geldbuße verwirkt. 


\section{\$. 14 .}

Das Vergehen des Nachdrucks ist vollendet, wenn Exemplare eines Buches vorgefunden werden, welche den gegenwärtigen Vorschriften zuwider angefertigt worden sind.

\section{\$. 15 .}

h. Untersuchungs =Verfahren .

Die gerichtliche Untersuchung der in den $\S \S .2 .3 .4$. bezeichneten Vergehen ist nicht von Amtswegen, sondern nur auf den Antrag der Verletzten einzuleiten.

Will der Verleger der Schrift den Antrag nicht machen, so kann dieses von dem Autor oder dessen Erben geschehen, in so fern dieselben noch ein von dem Verleger unabhăngiges Interesse haben.

\section{\$. 16 .}

Nach einmal erfolgter Einleitung der Untersuchung kann die Zurücknahme des Antrags zwar in Beziehung auf die Entschädigung stattfinden, nicht aber in Beziehung auf die Confiscation und Geldbuße.

\section{\$. 17 .}

Scheint es dem Richter zweifelhaft, ob eine Druckschrift als Nachdruck oder unerlaubter Abdruck $\mathrm{zu}$ betrachten ist, oder wird der Betrag der Entschädigung bestritten, so hat der Richter das Gutachten eines aus sachverständigen gebildeten vereins einzuholen.

Die Bildung eines oder mehrerer solcher Vereine, die vorzüglich aus geachteten Schriftstellern und Buchhăndlern bestehen sollen, bleibt einer besonderen, von Unserem Staats=Ministerium zu erlassenden Instruction vorbehalten. 


\section{s. 18 .}

2) Geographische, topographische, naturwissenschaftliche, architektonische und ähnliche Zeichnungen.

Was vorstehend in den $\S \S .1 .2 .5$ bis 17 . über das ausschließende Recht zur Vervielfältigung von Schriften verordnet ist, findet auch Anwendung auf geographische, topographische, naturwissenschaftliche, architektonische und ähnliche zeichnungen und Abbildungen, welche nach ihrem Hauptzwecke nicht als Kunstwerke ( $\$ .21$.$) zu betrachten sind.$

\section{§. 19 .}

3) Musikalische Compositionen.

Dieselben Vorschriften gelten hinsichtlich der ausschließenden Befugniß zur Vervielfältigung musikalischer Compositionen.

\section{\$. 20 .}

Einem verbotenen Nachdruck ist gleich zu achten, wenn Jemand von musikalischen Compositionen Auszüge, Arrangements für einzelne Instrumente, oder sonstige Bearbeitungen, die nicht als eigenthümliche Compositionen betrachtet werden können, ohne Genehmigung des Verfassers herausgiebt.

\section{\$. 21 .}

4) Kunstwerke und bildliche Darstellungen.

Die Vervielfăltigung von Zeichnungen oder Gemälden durch Kupferstich, Stahlstich, Holzschnitt, Lithographie, Farbendruck, Uebertragung u.s.w. ist verboten, wenn sie ohne Genehmigung des Urhebers des Original=Kunstwerks oder seiner Rechtsnachfolger bewirkt wird. 


\section{\$. 22 .}

Unter gleicher Bedingung ist die Vervielfältigung von Sculpturen aller Art durch Abgüsse, Abformungen u.s.w. verboten.

\section{\$. 23 .}

Hinsichtlich dieser Verbote, $\S \S .21$. und $22 .$, macht es keinen Unterschied, ob die Nachbildung in einer andern Größe, als das nachgebildete Werk, oder auch mit andern Abweichungen von demselben vorgenommen worden ist; es seien denn die Veränderungen so überwiegend, daß die Arbeit nicht als eine bloße Nachbildung, sondern als ein eigenthümliches Kunstwerk betrachtet werden könnte.

\section{\$. 24 .}

Als eine verbotene Nachbildung ist es nicht zu betrachten, wenn ein Kunstwerk, das durch die Malerei oder eine der zeichnenden Künste hervorgebracht worden ist, mittelst der plastischen Kunst, oder umgekehrt, dargestellt wird.

\section{\$. 25 .}

Die Benutzung von Kunstwerken als Muster zu den Erzeugnissen der Manufakturen, Fabriken und Handwerke ist erlaubt.

\section{§. 26 .}

Dauer des ausschließenden Rechts der Künstler,

a. bei unverăußertem Original.

Der Urheber eines Kunstwerkes und seine Erben genießen die ihnen in den $\S \S .21$ u. f. zugesicherten, ausschließenden Rechte, so lange das Original in ihrem Eigenthum bleibt. 


\section{\$. 27 .}

Wollen sie in dieser Lage von dem ihnen ausschließend zustehenden Rechte der Vervielfältigung Gebrauch machen und sich gegen die Eingriffe Anderer sichern, so haben sie von ihrem Unternehmen, ehe noch die erste Kopie an einen Andern abgelassen wird, zugleich mit der Erklärung, daß sie eine Vervielfältigung durch Andere, welche nicht die besondere ErlaubniB von ihnen erhalten haben, nicht zulassen wollen, dem obersten Curatorium der Künste (Ministerium der geistlichen, Unterrichts= und Medizinal=Angelegenheiten) Anzeige zu machen. Ist diese Anzeige und Erklärung erfolgt, so soll dem Künstler und seinen Erben das ausschließende Recht zur Vervielfältigung des Kunstwerkes für die Dauer von zehn Jahren zustehen. Wenn daher ein Anderer das von dem Urheber oder dessen Erben bereits vervielfältigte Kunstwerk mittelst irgend eines Kunstverfahrens nachbilden und das Nachbild verbreiten will, so hat er zuvor eine amtliche Aeußerung des obersten Curatoriums der Künste darüber einzuholen, ob eine Anzeige und Erklärung der obgedachten Art bei demselben abgegeben worden sei. Ist eine solche Anzeige und Erklärung unterblieben oder seit ihrer Abgebung ein Zeitraum von zehn Jahren abgelaufen, so ist die Nachbildung erlaubt.

\section{ฐ. 28 .}

b. nach Veräußerung des Originals.

Begeben sich der Urheber oder seine Erben des Eigenthums des Kunstwerkes, ehe mit dessen Vervielfältigung ein Anfang gemacht worden ist, so geht, falls eine ausdrückliche Verabredung darüber nicht statt gefunden hat, das ausschließende Recht dazu gănzlich verloren. Es kann aber auf die Dauer von zehn Jahren fortbestehen, entweder zu Gunsten des Urhebers oder seiner Erben, indem sie sich solches vorbehalten, oder $z u$ Gunsten des Erwerbers, indem sie ihm solches übertragen, in so fern nur in beiden Fällen gleichzeitig mit der Veräußerung eine Verabredung in glaubhafter Form darüber getroffen und davon dem obersten Curatorium der Künste die obgedachte Anzeige gemacht wird. 
Abbildungen von Original=Kunstwerken .

Die Abbildung eines Kunstwerkes, welche durch ein anderes, als bei dem Original angewendetes Kunstverfahren, z. B. durch Kupferstich, Stahlstich, Holzschnitt u. s. w. (\$. 21.), oder durch Abgüsse, Abformungen u.s.w. ( .22 .) rechtmäßig angefertigt worden, darf nicht ohne Genehmigung des Abbildners oder seiner Rechtsnachfolger, durch ein rein mechanisches Verfahren vervielfältigt werden, so lange die Platten, Formen und Modelle, mittelst welcher die Abbildung dargestellt wird, noch nutzbar sind. Auch hierbei kommt die Bestimmung des §. 23. zur Anwendung.

\section{s. 30 .}

Strafen und Untersuchungs=Verfahren.

Die Vorschriften der $\S \S .10$ bis 16. sollen auch in Beziehung auf Kunstwerke und bildliche Darstellungen aller Art in Anwendung kommen.

Die im §. 10. vorgeschriebene Confiscation ist auch auf die zur Nachbildung der Kunstwerke gemachten Vorrichtungen, als der Platten, Formen, Steine u. s. w. auszudehnen.

\section{\$. 31 .}

Der Richter hat, wenn Zweifel entsteht, ob eine Abbildung unter die Fälle des $\S .18$. oder unter die des $\S .21$. gehöre, ob im Falle des $\S$. 20. ein Musikstück als eigenthümliche Composition oder als Nachdruck, in den Fällen der $\S \S .21$. bis 29. eine Nachbildung, als unerlaubt $\mathrm{zu}$ betrachten, oder wie hoch der Betrag der dem Verletzten zustehenden Entschädigung zu bestimmen sei, und ob die im $\$ .29$. als Bedingung gestellte Nutzbarkeit der Platten, Formen und Modelle noch Statt finde, in gleicher Weise, wie §. 17. verordnet ist, das Gutachten eines aus Sachverständigen gebildeten Vereins zu erfordern. 
Die Bildung solcher Vereine, welche vorzugsweise aus Kunstverständigen und geachteten Künstlern bestehen sollen, bleibt ebenfalls der im $\S .17$. erwähnten Instruction vorbehalten.

§. 32 .

5) Oeffentliche Aufführung dramatischer und musikalischer Werke.

Die öffentliche Aufführung eines dramatischen oder musikalischen Werkes im Ganzen oder mit unwesentlichen Abkürzungen darf nur mit Erlaubniß des Autors, seiner Erben oder Rechtsnachfolger Statt finden, so lange das werk nicht durch den Druck veroffentlicht worden ist. Das ausschließende Recht, diese Erlaubniß zu ertheilen, steht dem Autor lebenslänglich und seinen Erben oder Rechtsnachfolgern noch zehn Jahre nach seinem Tode zu.

\section{\$. 33 .}

Hat der Autor jedoch irgend einer Bühne gestattet, das Werk ohne Nennung seines Namens aufzuführen, so findet auch gegen andere Bühnen kein ausschließendes Recht statt.

\section{\$. 34 .}

Wer dem ausschließenden Rechte des Autors oder seiner Rechtsnachfolger zuwider, ein noch nicht durch den Druck veröffentlichtes dramatisches oder musikalisches Werk öffentlich aufführt, hat eine Geldbuße von zehn bis hundert Thalern verwirkt.

Findet die unbefugte Aufführung eines dramatischen Werkes auf einer stehenden Bühne Statt, so ist der ganze Betrag der Einnahme von jeder Aufführung, ohne Abzug der auf dieselbe verwendeten Kosten, und ohne Unterschied, ob das Stück allein, oder verbunden mit einem andern, den Gegenstand der Aufführung ausgemacht hat, zur strafe zu entrichten.

Von den vorstehenden Geldbußen fallen zwei Drittheile dem Autor oder seinen Erben, und ein Drittheil der Armen=Casse des Orts zu. 
\$. 35 .

6) Allgemeine Bestimmungen.

Das gegenwärtige Gesetz soll auch zu Gunsten alter bereits gedruckten Schriften, geographischen, topographischen und ähnlichen Zeichnungen, musikalischen Compositionen und vorhandenen Kunstwerke in Anwendung kommen.

\section{\$. 36 .}

Dem Inhaber eines vor Publikation des gegenwärtigen Gesetzes ertheilten Privilegiums steht es frei, ob er von diesem Gebrauch machen, oder den Schutz des Gesetzes anrufen will.

\section{s. 37 .}

All diesem Gesetze entgegenstehende oder von ihm abweichende frühere Vorschriften treten außer Kraft.

\section{\$. 38 .}

Auf die in einem fremden Staate erschienenen Werke soll dieses Gesetz in dem Maaße Anwendung finden, als die in demselben festgestellten Rechte den in Unseren Landen erschienenen Werken durch die Gesetze dieses Staates ebenfalls gewährt werden.

Urkundlich unter Unserer Höchsteigenhändigen Unterschrift und beigedrucktem Königlichen Insiegel.

Gegeben Berlin, den 11ten Juni 1837.

(gez.) Friedrich Wilhelm.

Carl, Herzog von Mecklenburg. Frhr. v. Altenstein. v. Kamptz. Mühler.

Beglaubigt :

Für den Staats=Secretair Düesberg.

Gesetz zum Schutze des Eigenthums an Werken der Wissenschaft und Kunst gegen Nachdruck und Nachbildung. 


\section{Bibliography}

\section{Books and Publications}

Bailey, H.: The Art and Science of Book Publishing (1970)

Bal1, H.: The Law of Copyright and Literary Property (1944)

Beier, F.K., Schricker, G. \& Fikentscher, W.: German Industrial Property, Copyright and Antitrust Laws, IIC Studies, Vol. 6 (Weinheim, VCH, 2nd ed. 1989)

Bercovitz, R.: Comentarios a la Ley de Propiedad Intelectual (Madrid, Tecnos 1989)

Birrel1, A.: Seven Lectures on the Law and History of Copyright in Books (London, Cassell \& Co. Ltd. 1899)

Brennan, T.J.: Economic Analysis Group Discussion Paper, US Dept. of Justice, Antitrust Division, Taxing Home Audio Taping, 15 April, 1986

Bugbee, B.W.: Genesis of American Patent and Copyright Law (Washington, Public Affairs Press 1967)

The Challenge of the Information Highway, Final Report of the Information Highway Advisory Council, Canada, 1995

Colombet, $C_{.}:$Grands principes du droit d'auteur et des droits voisins dans le monde (Unesco 1990)

Copyright Council of New Zealand, Employment in Copyright Based Industries, 1993

Cornish, W.R.: Intellectual Property: Patents, Copyright, Trademarks and Allied Rights (London, Sweet \& Maxwell, 2nd ed. 1989) 
Cramer, J.S., Meijering, J.M. \& Nijseen, T.J.M.: The Economic Importance of Copyright in the Netherlands in 1982, survey commissioned by Stichting Auteursrechtbelangen (Amsterdam, SEO 1986)

Davies, G. \& Hung, M.: Music and Video Private Copying, An International Survey of the Problem and the Law (London, Sweet \& Maxwell 1993)

Desbois, H.: Le droit d'auteur en France (Paris, Dalloz, 3rd ed. 1978)

Desbois H., Francon $A$. \& Kerever $A$. : Les conventions internationales du droit d'auteur et des droits voisins (1976)

Dietz, A.: Copyright Law in the European Community (Alphen aan den Rijn, Sijthoff \& Noordhoff 1978)

Dock, M.-C.: Etude sur le droit d'auteur, Librairie générale de droit et de jurisprudence (Paris 1963)

Dworkin G. \& Taylor R.D.: Blackstone's Guide to the Copyright, Designs and Patents Act 1988 (London, Blackstone Press Ltd. 1989)

Eddy, J.P.: The Law of Copyright (London, Butterworth \& Co. 1957)

The English Book Trade 1660-1853 (Warburton on Literary Property) (London, Garland Publishing Co., 1974)

Escarra, J., Rault, J. \& Hepp, F.: La doctrine française du droit d'auteur (Paris, Editions Bernard Grasset 1937)

Europe's Way to the Information Society, An Action Plan, Communication of the Commission to the Council and the European Parliament, (COM (94) 347 final) 19 July 1994

European Commission Green Paper on Copyright and Related Rights in the Information Society, 19 July 1995 


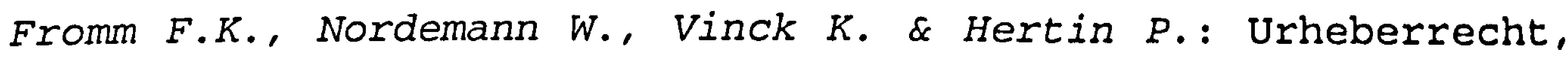
Kommentar (7th ed. 1988)

von Gamm, O.F.: Urheberrechtsgesetz, Kommentar (Munich, Beck Verlag 1968)

Ghering, M., Van Puffelen, F. \& Schilthuis, F.: The Economic Importance of Copyright in the Netherlands in 1985 (Amsterdam 1989)

Goldstein, P.: Copyright Principles, Law and Practice, 3 Vols. (Boston, Little, Brown \& Co. 1989)

Guldberg, H. \& Candi, E.: Copyright - An Economic Perspective, Study prepared for the Australian Copyright Council (Sydney 1987)

Halsbury's Laws of England, fourth edition, Lord Hailsham of St. Marylebone, Vol. 9, Butterworths, London, 1974

Heymann, E.: Die zeitliche Begrenzung des Urheberrechts (Berlin, Verlag der Akademie der Wissenschaften 1927)

Hummel, M.: Die Volkswirtschaftliche Bedeutung des Urheberrechts, Vol. 125 in the series of the IFO Institut für Wirtschaftsforschung, with a summary in English (Berlin \& Munich, Duncker \& Humbolt 1989)

Hummel, M., Berger, M. \& Müller, F.: Die volkswirtschaftliche Bedeutung von Kunst und Kultur, Gutachten im Auftrag des Bundesministers des Innern, Vol. 122 in the series of the IFO Institut für Wirtschaftsforschung (Berlin \& Munich 1988)

Kaplan, B.: An Unhurried View of Copyright, James S. Carpentier Lectures, (New York \& London, Columbia University Press 1967)

Kase, J.R.: Copyright Thought in Continental Europe (1971) 
Kirchhof, P.: Der Gesetzgebungsauftrag zum Schutz des geistigen Eigentums gegenüber modernen Vervielfältigungstechniken (Heidelberg, Decker \& Müller Verlag 1988)

Laboulaye, L. \& Guiffrey, G.: La propriété littéraire au XVIII siècle, Hachette, Paris (1859)

Ladas, S.P.: The International Protection of Literary and Artistic Property, 2 Vols. (New York, Macmillan 1938)

Lehmann, H.: Über das Wesen des Urheberrechts, Vol. 2 in the Series of the Internationale Gesellschaft für Urheberrecht (Berlin, Verlag Musik und Dichtung 1956)

Lucas, A. and H.-J.: Traité de la propriété Littéraire \& Artistique, Litec, Librairie de la Cour de Cassation, Paris, 1994

MacQueen, H.L.: Copyright, Competition and Industrial Design, Second edition, Hume Papers on Public Policy: Vol. 3, No. 2, Edinburgh University Press, 1995

Manni-Loukkola, S. \& Esala, P.: A Study of the Economic Importance of Copyright-Related Industries in Finland (Helsinki 1988)

Masouyé, C.: WIPO Guide to the Berne Convention, WIPO publication (Geneva 1978)

Mestmäcker, E.-J.: Copyright in Community Law, Journal of World Trade Law, Special Supplement No. 3, 1976

Neumann, T.: Urheberrecht und Schulgebrauch, UFITA Vol. 115 (Baden-Baden, Nomos 1994)

Nimmer, M.B.: Nimmer on Copyright. A Treatise on the law of Literary, Musical and Artistic Property and the Protection of Ideas, 5 Vols. (New York, Matthew Bender 1992)

Nimmer, M.B.: Studies on Copyright (Fisher Memorial Edition 1960) 
Nordemann, W., Vinck, K. \& Hertin, P.: International Copyright and Neighboring Rights Law (Weinheim, VCH 1990)

O'Donnell, G.C.: A Short Note on Anti-Copyright (Copyright Agency Ltd. Australia, 1985)

OECD (Organisation for EConomic Cooperation and Development) Trade Division: Economic Arguments for Protecting Intellectual Property (Paris, November 1990)

Patterson, L.R.: Copyright in Historical Perspective (Nashville, Vanderbilt University Press 1968)

Phillips, J.: The Economic Importance of Copyright (London, CLIP 1985)

Posner, R.A.: Economic Analysis of Law (Boston, Little, Brown \& Co., 2nd ed. 1977)

Pouillet, E.: Traité théorique et pratique de la propriété littéraire et artistique (Paris, Marchal et Billard, 3rd ed. 1908)

Putnam, G.H.: The Question of Copyright (New York, The Knickerbocker Press, 2nd ed. 1896)

Putnam, G.H.: Books and their Makers During the Middle Ages, 1476-1600 (New York \& London 1896)

von Rauscher auf Weeg, H.H.: Das Musikalische Urheberrecht und der Schutz von Werkteilen, doctoral thesis, Heidelberg University (1954)

Records of the WIPO Worldwide Symposium on the Impact of Digital Technology on Copyright and Neighbouring Rights, Harvard University, 1993, WIPO Publication No. 723 (1993) 
Records of the WIPO Worldwide Symposium on the Future of Copyright and Neighbouring Rights, Paris, 1994, WIPO Publication No. 731

Records of the WIPO Worldwide Symposium on Copyright in the Global Information Infrastructure, Mexico City, 1995, WIPO Publication Nr. 746.

Renouard, A.Ch.: Traité des droits d'auteurs dans la littérature, les sciences et les beaux arts, 2 Vols. (Paris, Jules Renouard et Cie. Libraires 1838)

Ricketson, S.: The Berne Convention for the Protection of Literary and Artistic Works 1886-1986 (London, Centre for Commercial Law Studies, Queen Mary College 1987)

Rose, M.: Authors and Owners, The Invention of Copyright, Harvard University Press, 1993

Rubin, M.R.: The Copyright Industries in the United States in 1980, study prepared for the American Council, (Washington, D.C. 1985)

Rüster, B. (Ed.): Business Transactions in Germany (New York, Matthew Bender 1982)

Scheuch, F. \& Holzmüller, H.: Die wirtschaftliche Bedeutung des Urheberrechts in Österreich (Vienna 1989)

Schricker, G.: Urheberrecht, Kommentar (Munich, Beck Verlag, 1st ed. 1987)

Schultze, E. \& Mestmäcker, E.J.: Kommentar zum deutschen Urheberrecht unter Berücksichtigung des internationalen Rechts und des Gemeinschaftsrechts in den Mitglied-staaten der EG (Frankfurt, Metzner 1982)

Sherman, B. and Strowel, A.: Of Authors and Origins, Essays on Copyright Law, Clarendon Press, Oxford, 1994 
Siwek, S. \& Furchtgott-Roth, H.: Copyright Industries in the US Economy, Reports prepared for the International Intellectual Property Alliance, 1990, 1992, 1993 and 1995

Skilbeck, J.: The Economic Importance of Copyright - An International Survey, $23 \mathrm{rd}$ Congress of the International Publishers Association, 1988

Skilbeck, J.: The Export Performance of the Copyright-Dependent Industries (London, CLIP 1988)

Skone James, E.P.: Mummery, J.F., Rayner James, J. \& Garnett, K.M.: Copinger and Skone James on Copyright (London, Sweet \& Maxwel1, 13th ed. 1991)

Steenbergen, J.: Intellectual Property and the Uruguay Round in GATT: The Interests of Industry, CEPS Business Policy study No. 1 (Brussels, CEPS 1988)

Stewart, S.M.: International Copyright and Neighbouring Rights (London, Butterworths, 2nd ed. 1989)

Street, H.: Freedom, the Individual and the Law (Penguin, 5th ed. 1982)

Strömholm, S.: Le droit moral de l'auteur en droit Allemand, Français et Scandinave, 3 Vols. (Stockholm, Norstedt \& Söners 1967)

Stroombergen, A.: The Economic Importance of Copyright - The Economic Contribution of Copyright-Based Industries in New Zealand (Wellington 1989)

Strowel, A.: Droit d'auteur et copyright. Divergences et convergences. Etude de droit comparé (Brussels) 1993.

Ulmer, E.: Urheber- und Verlagsrecht (Berlin, Heidelberg \& New York, Springer Verlag, 3rd ed. 1980) 
Voge1, M.: Deutsche Urheber- und Verlagsrechtsgeschichte zwischen 1450 und 1850 (Frankfurt 1978)

Waldon, J.: The Right to Private Property (Oxford, Clarendon Press 1988)

White, H.S. (Ed.): The Copyright Dilemma (Chicago, American Library Association 1978)

Wittenberg, P.: The Protection of Literary Property (Boston, The Writer Inc. Publishers, revised ed. 1978)

\section{Articles}

Abrams, H.: The Historic Foundation of American Copyright Law: Exploding the Myth of Common Law Copyright, 29 Wayne Law Rev. 1119 (1985)

Adelstein, R. \& Peretz, S.: The Competition of Technologies in Markets for Ideas: Copyright and Fair Use in Evolutionary Perspective, 5 Int. Rev. of Law and Economics 209 (1985)

Baker, T.: The Property Concepts of Copyright Law, 22 Missouri Law Rev. 200 (1957)

Becourt, D.: La révolution française et le droit d'auteur pour un nouvel universalisme, 143 RIDA 231 (1990)

Besen, S., Kirby, S. \& Salop, S.: An Economic Analysis of Copyright Collectives, working paper prepared for Georgetown University Law Center, Washington 1991

Blanco White T.: A Future for British Concepts?, 1988 EIPR 229

de Boor H.O.: Lettre d'Allemagne, 1928 Le Droit d'Auteur 38 de Boor H.O.: Lettre d'Allemagne, 1934 Le Droit d'Auteur 115 
de Boor H.O.: Lettre d'Allemagne, 1936 Le Droit d'Auteur 115 de Boor H.O.: Lettre d'Allemagne, 1937 Le Droit d'Auteur 111 de Boor H.O.: Lettre d'Allemagne, 1938 Le Droit d'Auteur 117 de Boor H.O.: Lettre d'Allemagne, 1939 Le Droit d'Auteur 111 de Boor H.O.: Lettre d'Allemagne, 1940 Le Droit d'Auteur 112 de Boor H.O.: Lettre d'Allemagne, 1941 Le Droit d'Auteur 121 de Boor H.O.: Lettre d'Allemagne, 1942 Le Droit d'Auteur 110 de Boor H.O.: Lettre d'Allemagne, 1943 Le Droit d'Auteur 123 de Boor H.O.: Lettre d'Allemagne, 1944 Le Droit d'Auteur 10 de Boor H.O.: Lettre d'Allemagne, 1945 Le Droit d'Auteur 61 de Boor H.O.: Lettre d'Allemagne, 1948 Le Droit d'Auteur 134 de Boor H.O.: Lettre d'Allemagne, 1950 Le Droit d'Auteur 63 de Boor H.O.: Lettre d'Allemagne, 1951 Le Droit d'Auteur 29 de Boor H.O.: Lettre d'Allemagne, 1953 Le Droit d'Auteur 30 de Boor H.O.: Lettre D'Allemagne, Part I, 1954 Le Droit d'Auteur 71, Part II, 1954 Le Droit d'Auteur 95

de Boor H.O.: Lettre d'Allemagne, 1955 Le Droit d'Auteur 4 de Boor H.O.: Lettre d'Allemagne, 1955 Le Droit d'Auteur 203 Boutet, M.: Réflexions, IV RIDA 3 (1954) Boutet, M.: Considérations générales, XIX RIDA 13 (1958) 
Braun, T.: Bedeuten Herstellung und Vertrieb von DoppelVideorecordern eine Urheberrechtsverletzung?, 11 ZUM 487 (1990)

Breyer, S.: The Uneasy Case for Copyright: A Study in Copyright in Books, Photocopies and Computer Programs, 84 Harv. L. Rev. 281 (1970)

Breyer, S.: Copyright: A Rejoinder, 20 UCLA L. Rev. 75 (1972)

Chafee, Z.: Reflections on the Law of Copyright, 45 Columbia Law Rev. 503 and 719 (1945)

Christie, A.: Reconceptualising Copyright in the Digital Era, [1995] 11 EIPR 522

Clark, C.: The Copyright Environment for the Publisher in the Digital World, International Publishers' Association, March 1996

Cohen Jehoram, H.: Critical Reflections on the Economic Importance of Copyright, 20 IIC 485 (1989)

Cornish, W.R.: Moral Rights Under the 1988 Act, 12 EIPR 449 (1989)

Cornish, W.R.: Intellectual Property, in 13 Yearbook of European Law 485 (1994)

Cottier, T.: The value and effects of protecting intellectual property rights within the World Trade Organisation, in ALAI Geneva study session 1994, Groupe suisse de I'ALAI et les auteurs, Berne 1994, 16.

Davies, G.: The Public Interest in Collective Administration of Rights, 1989 Copyright 82

Davies, G.: New Technology and Copyright Reform, 12 EIPR 335 (1984) 
Davies, G.: New Technology and Copyright Reform - The Viewpoint of the Music Industry, The Council of Europe, document CC-GP 11 (84) 8 (Strasbourg 1984)

Davies, G.: The Convergence of Copyright and Authors' Rights Reality or Chimera?, 26 IIC 964 (1995)

Davis, I.: A Century of Copyright: The United Kingdom and the Berne Convention, 1986 Copyright 117

Davison, M.: Geographical Restraints on the Distribution of Copyright Material in a Digital Age: Are they Justified? [1996] 9 EIPR 477

De Freitas, D.: Economic Arguments for Protecting Intellectual Property, 2 Intellectual Property in Business 26 (1990)

Deely, P.: Copyright, Limitation on Exclusive Rights: Fair Use, 13 Houston Law Rev. 1041 (1976)

Desbois, H.: The Moral Right, XIX RIDA 121 (1958)

Desbois, H.: La loi française du 11 mars 1957, 1957 Le Droit d'Auteur 184

Dietz, A.: Letter from Germany, Part I, 1973 Copyright 93, Part II, 1974 Copyright 86

Dietz, A.: Letter from Germany, Part I, 1980 Copyright 85, Part II, 1980 Copyright 129

Dietz, A.: Letter from Germany, Part I, 1984 Copyright 426, Part II, 1984 Copyright 457

Dietz, A.: Letter from Germany, Part I, 1990 Copyright 58, Part II, 1990 Copyright 96

Dietz, A.: Copyright Law Developments in the Federal Republic of Germany, 157 RIDA 128 (1993) 
Dillenz, W.: Functions and Recent Developments of Continental Collecting Societies, 6 EIPR 191 (1990)

Dixon, A.N. and Self, L.C.: Copyright Protection for the Information Superhighway, [1994] 11 EIPR 465

Dock M.-C.: Genèse et évolution de la notion de la propriété littéraire, LXXIX RIDA 165 (1974)

Dworkin G.: Moral Rights in English Law - the Shape of Things to Come, 11 EIPR 329 (1986)

Ermecke, G.: The Social Significance of Intellectual Property, lecture given at the Congress of the International Copyright Society, Berlin, September 16, 1962.

Escarra, J.: Le projet de loi française sur la propriété littéraire et artistique, V RIDA 3 (1954)

Evans, L.: Copyright and the Public Interest, 53 Bulletin of the New York Public Library 3 (1949)

Fabiani, M.: A Profile of Copyright in Today's Society, 1982 Copyright 152

Feather, J.: Authors, Publishers and Politicians: The History of Copyright and the Book Trade, 12 EIPR 377 (1988)

Fernay, R.: Grandeur, misère et contradictions du droit d'auteur, 1979 Il Diritto di Autore Anno L 419, 109 RIDA 138 (1981)

Ficsor, M.: Disquieting Report from the Maginot Line of Authors, 1982 Copyright 104

Finkelstein, T.: La loi américaine de 1790 sur le droit d'auteur, XXXVII RIDA 35 (1963)

Françon, A.: Letter from France, 1986 Copyright 359 
Françon, A.: Letter from France, 1991 Copyright 283

Friedman, B.: From Deontology to Dialogue: The Cultural Consequences of Copyright, 13 Cardozo Arts and Entertainment (1994) 157 .

Geller, P.E.: Can the GATT Incorporate Berne Whole?, 4 World Intellectual Property Report 193 (1990)

Geller, P.E.: The Universal Electronic Archive: Issues in International Copyright, 25 IIC (1994) 54

Geller, P.E.: New Dynamics in International Copyright, 16 Colum.VLA J.L. \& Arts 461 (1993)

Geller, P.E.: The Universal Electronic Archive: Issues in International Copyright, 25 IIC 54 (1994)

Gendreau, Y.: Digital Technology and Copyright: Can Moral Rights Survive the Disappearance of the Hard Copy?, [1995] 6 ENT. LR 214

Ginsburg, J.C.: A Tale of Two Copyrights: Literary Property in Revolutionary France and America, 147 RIDA 125 (1991)

Ginsburg, J.C.: Copyright in the US Since Berne Accession, 61 NIR (Nordiskt Immateriellt Rättskydd/Nordic Intellectual Property Review) 159 (1992)

Goldberg, G.: Copyrights and the Public Interest, 50 American Bar Assoc. Journal 56 (1964)

Goldstein, P.: Copyright and the First Amendment, 70 Columbia Law Rev. 983 (1970)

Goldstein, P.: Copyright; The Donald C. Brace Memorial Lecture, 38 Journal of the Copyright Society of the USA, No. 3 (1991) 109 
Gordon, W.J.: Fair Use as Market Failure: A structural and Economic Analysis of the Betamax Case and its Predecessors, 82 Columbia Law Rev. 1600 (1982)

Gordon, W.J.: An Enquiry into the Merits of Copyright: The Challenges of Consistency, Consent, and Encouragement Theory, 41 Stanford L. Rev. 1343 (1989)

Hemmer, J.J.: The Supreme Court and the First Amendment, Praeger Special Studies, Vol. XV (New York, Praeger 1986)

Hemnes, T.: Three Common Fallacies in the User Interface Copyright Debate, 6 Computer Law \& Practice 163 (1990)

Hesse, C.: Enlightenment Epistemoloy and the Laws of Authorship in Revolutionary France, 1777-1793, 30 Representations (1990) 109

Hesser, T.: Letter from Sweden, 1965 Copyright 18

Hirsch-Ballin, E.D.: Gegenüberstellung der Rechte des Urhebers mit denen der Allgemeinheit (Authors' Rights Compared with Those of the Community), X RIDA 18 (1956)

Hummel, M.: The Economic Importance of Copyright, 12 IFO-Digest, 4/89, at 32 (Munich, IFO Institute for Economic Research)

Hummel, M.: The Economic Importance of Copyright, XXIV UNESCO Copyright Bulletin, No. 2, at 14 (1990)

Hurt, R.M. \& Schuchman R.M.: The Economic Rationale of Copyright, 56 Am. Econ. Rev. 426 (1966)

Jolibois, C.: Report of the Commission (Doc. Sénat No. 350), 127 RIDA 278 (1986)

Jovanovich, W.: To Vouchsafe Identity, 14 Bulletin of the Copyright Society of the USA 355 (1967) 
Kaplan, B.: Performer's Right and Copyright: The Capitol Records Case, 69 Harvard Law Rev. 409 (1956)

Karjala, D.S. et al.: Comment of US Copyright Law Professors on the Copyright office Term of Protection Study, [1994] 12 EIPR 531

Kasdan, J.: The Economics of Copyright with Applications to Licensing, working paper prepared for Columbia Law School, October 1986

Kastenmeier, R.W.: The 1989 Horace Manges Lecture - Copyright in an Era of Technological Change: A Political Perspective, 14 Colum. - VLA J.L. \& Arts 1 (1989)

Kastenmeier, R.W. and Remington, M.J.: The Semiconductor Chip Protection Act of 1984: A Swamp or Firm Ground? 70 Minnesota L. Rev. 417 (1985)

Kaufmann, G.: Exposing the Suspicious Foundations of Society's Primacy in Copyright Law: Five Accidents, 10 Colum-VLA J.L \& Arts, 381 (1986)

Kerever, A.: Le droit d'auteur français et l'Etat, 110 RIDA 3 (1981)

Kerever, A.: Is Copyright an Anachronism?, 1983 Copyright 368

Kerever, A.: One Aspect of the Law of 3 July 1985: Modernisation of the Law of 11 March 1957, 127 RIDA 22 (1986)

Kerever, A.: La révolution française et le droit d'auteur, 141 RIDA 9 (1989)

Kerever, A.: Le droit d'auteur, son présent et son avenir, 143 RIDA 3 (1990)

Kerever, A.: Copyright: The Achievements and Future Development of European Legal Culture, 1990 Copyright 130 
Koktvedgaard, M.: Ophavsrettens existensberettigelse, 1975 NIR 294

Kreile, R.: The 1989 Amendment to the German Copyright Act, 1990 Copyright World 24

Kreile, R.: Collection and Distribution of the statutory Remuneration for Private Copying with Respect to Recorders and Blank Cassettes in Germany, 23 IIC 449 (1992)

Lacey, L.J.: Of Bread and Roses and Copyright, 1989 Duke Law Journal 1532

Ladd, D.: The Concept of Harm in Copyright, 1983 Bull. Cop. Soc. USA 421

Ladd, D.: To Cope with the World Upheaval in Copyright, 1983 Copyright 289

Ladd, D.: Securing the Future of Copyright, a Humanist Endeavor, lecture given for the International Publishers Association, Mexico, March 1984

Ladd, D.: Die Sorge um die Zukunft des Urheberrechts als humanistischer Auftrag, 1985 GRUR Int. 77

Laddie, H.: Copyright: Overstrength, Over-regulated, Over-rated?, [1996] 5 EIPR 253

Laligant, 0.: La révolution française et le droit d'auteur ou pérennité de l'objet de la protection, 147 RIDA 3 (1991)

Landes, W. \& Posner, R.: An Economic Analysis of Copyright Law, 18 Journal of Legal Studies 325 (1989)

Lang, J.: La Loi du 3 juillet 1985, 127 RIDA 6, 168 (1986)

Lassen, B.S.: Collectivism and Individual Rights in Norwegian Copyright Law, 1963 Scandinavian studies in Law 79 
Lehmann, M.: Property and Intellectual Property - Property Rights as Restrictions on Competition in Furtherance of Competition, 20 IIC 1 (1989)

von Lewinski, S.: EC Proposal for a Council Directive Harmonizing the Term of Protection of Copyright and Certain Related Rights, 23 IIC 785 (1992)

Liedes, J.: A Study of the Economic Importance of CopyrightRelated Industries in Finland, 1988 ALAI Journées d'Etude 44

Light, S.N.: Parody, Burlesque and the Economic Rationale for Copyright, 11 Connecticut Law Review, No. 4, 615 (1979)

Litman, J.: Copyright and Information Policy, 55 Law and Contemporary Problems (1992) 185

Ljungman, S.: Något om verkshöjd, 1972 NIR 35

Ljungman, S.: The Function of Copyright in the Present Day Society, 88 RIDA 51 (1976)

Masouyé, C.: Vers une prolongation de la durée générale de protection, XXIV RIDA 93 (1959)

Masouyé, C.: Droit d'auteur: Horizon 2000 ou la grandeur et les servitudes du droit d'auteur, 1979 Il Diritto di Autore 163

Masterson, S.: Copyright: History and Development, 28 California Law Rev. 620 (1940)

Matthyssens, J.: Copyright Law Schemes in France during the Last Century, IV RIDA 15 (1954)

Mayton, W.T.: Seditious, Libel and the Lost Guarantee of a Freedom of Expression, 84 Colum. Law Rev. 91 (1984)

Metaxas-Marangidis, G.: EC Law and the Future of Copyright Management Societies, 1990 Copyright World 15 
Möller, M.: The Reform of the Copyright Law in the FRG, 1986 Copyright 271

Möller, M.: Collective Administration of Copyright and Neighbouring Rights - the Experience in the FRG, 1988 Copyright 482

Monta, R.: The Concept of "Copyright" Versus the "droit d'auteur", 32 Southern California Law Rev. 177 (1959)

Morrill, S.: Harper \& Row, Publishers $v$ National Enterprises: Emasculating the Fair Use Accommodation of Competing Copyright and First Amendment Interests, 79 Northwestern University Law Rev. 587 (1984)

Muenchinger, N.E.: French Law and Practice Concerning Multimedia and Telecommunications, [1996] 4 EIPR 186.

Muskovic, N.: Copyright and CDI, 8 International Media Law 46 (1990)

Nimmer, D.: The Impact of Berne on United States Copyright Law, 8 Carduzo Arts \& Entertainment Law Journal 27 (1989)

Nimmer, M.B.: Does Copyright Abridge the First Amendment Guarantees of Free Speech and Press?, 17 UCLA Law Rev. 1180 (1970)

Nordemann, W.: The 1972 Amendment of the German Copyright Act, 4 IIC 179 (1973)

Nordemann, W.: A Right to Control or Merely to Payment? - Towards a Logical Copyright System, 11 IIC 49 (1980)

Oakes, J.E.: Copyright and the First Amendment: Where Lies the Public Interest?, 59 Tulane Law Rev. 135 (1984) 
von Olenhausen, A.G.: Ewiges geistiges Eigentum und Sozialbindung des Urheberrechts in der Rechtsentwicklung und Diskussion in: 19. Jahrhundert in Frankreich und Deutschland, in Herschel, W., Hubmann, H. \& Rehbinder, M. (Eds.): FS Georg Roeber zum 10. Dezember 1981 (Freiburg, HochschulVerlag 1982)

Olson, T.P.: The Iron Law of Consensus: Congressional Responses to Proposed Copyright Reforms Since the 1909 Act, 36 Journal, Copyright Soc. of the USA, 109 (1989)

Olsson, A.H.: Copyright in the National Economy, 1982 Copyright 130

Olsson, A.H.: Copyright and the National Economy, 7 EIPR 179 (1984)

Olswang, S.: Accessright: An Evolutionary Path for Copyright into the Digital Era? [1995] 5 EIPR 215

Oman, R.: The Role of the United States in International Copyright, speech at the Finnish Copyright Society in Helsinki, 22 August 1989, 58 NIR (Nordiskt Immateriellt Răttsskydd/Nordic Intellectual Property Review) 243 (1989)

Oman, R.: Berne Revision: The Continuing Drama, 7 World Intellectual Property Report, 160 (1993)

Palmer, T.G.: Are Patents and Copyrights Morally Justified? The Philosophy of Property Rights and Ideal Objects? 13 Harvard Journal of Law and Public Policy 816 (1990)

Pares, P.: La conception française du droit d'auteur, II RIDA 3 (1954)

Parrinder, P.: The Dead Hand of European Copyright, [1993] 11 EIPR 391

Patterson, L.R.: The Statute of Anne: Copyright Misconstrued, 3 Harv. Law Rev. 223 (1966) 
Patterson, L.R.: Copyright and Author's Rights: A Look at History, XVI Harvard Library Bulletin, No. 4, 370 (1968)

Patterson, L.R.: Private Copyright and Public Communication: Free Speech Endangered, 28 Vanderbilt Law Rev. 1161 (1975)

Patterson, L.R.: Free Speech, Copyright and Fair Use, 40 Vanderbilt Law Rev. 1 (1987)

Philips, J.: Copyright: Towards a Positive Approach?, LXXXII RIDA 34 (1974)

Philips, J.: The Berne Convention and the Public Interest, 11 Colum.-VLA J. I. and A. 165 (1986)

Plaisant, M.: Bienvenue à la Loi, XIX RIDA 9 (1958)

Plaisant, $R .:$ La protection du logiciel par le droit d'Auteur, 1983 G.P.2. 348

Plant, A.: The New Commerce in Ideas and Intellectual Property, stamp Memorial Lecture (London, Athlone Press 1953)

Plant, A.: The Economic Aspects of Copyright in Books, in: Plant, A., Selected Economic Essays and Addresses (London \& Boston 1974)

Prager, F.D.A.: A History of Intellectual Property From 1545 to 1787, 26 Journal of the Patent Office Society, No. 11 (1944) 711

Prager, F.D.A.: The Early Crown and Influence of Intellectual Property, 34 Journal of the Patent Office Society, No. 2 (1952) 106

Pratt, E.T.: Intellectual Property Role in US Trade Policy, 1988 Review of the LES 159

Prescott, P.: The Origins of Copyright: A Debunking View, 12 EIPR 453 (1989) 
Price, T.: The Economic Importance of Copyright, Common Law Institute of Intellectual Property, London, 1993

Radojkovic, z.: The Legal Character of the "Moral Right", 1965 Copyright 203

Recht, P.: Copyright, a New Form of Property, 1969 Copyright 94

Reute, M.: The Kirchenmusik Judgment - Constitutional and Intellectual Property Rights, (1980) EIPR 198

Revue international du droit d'auteur: special issues on the French law (July 3, 1985, January 27, 1986 and April 28, 1986)

Richard, A.: Report, 127 RIDA 176 (1986)

Ricketson, S.: The Copyright Term, 23 IIC 753 (1992)

Ringer, B.: Renewal of Copyright, Study No. 1, Vol. 1, Studies in Copyright (1963)

Ringer, B.: The Role of the United States in International Copyright - Past, Present and Future, 56 Georgetown Law Journal 1050 (1968)

Ringer, B.: Copyright in its Historical and Philosophic setting. From records of a meeting of the Information Industry Association, July 18-19, 1969, published by Information Industry Association, 1970

Ringer, B.: The Demonology of Copyright, Bowker Memorial Lecture, November 18, 1974, US Publishers Weekly, November 18, 1974

Ringer, B.: Copyright and the Future of Authorship, 1976 Copyright 156

Ringer, B.: Copyright in the 1980's, 1976 Bulletin of the Copyright Society of the USA 299 
Ringer, B.: Two Hundred Years of American Copyright Law, Bicentennial Symposium of the American Bar Association, 1976

Ringer, B.: Author's Rights in the Electronic Age: Beyond the Copyright Act of 1976, 1 Loyola Entertainment Law Journal 1 (1981)

Roeber, G.: Urheberrecht oder Geistiges Eigentum, 21 UFITA 150 (1956)

Rose, M.: The Author as Proprietor: Donaldson and Beckett and the Genealogy of Modern Authorship, in of Authors and Origins, Essays on Copyright Law, eds. Sherman Brad and Strowel, Alain, Clarendon Press, Oxford, 1994

Rosenfield H.N.: The Constitutional Dimension of Fair Use in Copyright Law, 50 Notre Dame Law Rev. 790 (1975)

Rumphorst, W.: Comment on the School Book Case, 3 IIC 401 (1972)

Samuelson, P.: Digital Media and the Changing Face of Intellectual Property Law, 16 Rutgers Computer and Technology L.J. $323(1990)$

De Sanctis, V.: De la nature juridique du droit d'auteur, 1962 Interauteurs, No. 146, 12

De Sanctis, $\quad .:$ Le développement et la consécration internationale du droit d'auteur, LXXIX RIDA 207 (1974)

Saunders, D.: Purposes or Principle? Early Copyright and the Court of Chancery, [1993] 12 EIPR 452

Sayal, M.: Copyright and Freedom of the Media: A Balancing Exercise? [1995] 7 ENT. LR 263 
Schricker, G.: Hundert Jahre Urheberrechtsentwicklung, in Festschrift zum hundertjährigen Bestehen der Deutschen Vereinigung für gewerblichen Rechtschutz und Urheberrecht und ihrer Zeitschrift, VCH Verlagsgesellschaft mbH, Weinheim (1991) Part 4 , at 1095 .

Simon, E.: The Integration of Intellectual Property and Trade Policy, in "Economy and authors' rights in the international conventions", ALAI Geneva study session 1994, Groupe suisse de I'ALAI et les auteurs, Berne 1994, 33 .

Slaughter, J.: TRIPS: The GATT Intellectual Property Negotiations Approach their Conclusion, 11 EIPR 418 (1990)

Stewart, S.: Two Hundred Years of English Copyright Law, Bicentennial Symposium, American Bar Association, 1976, 1977 Copyright 225

Stewart, S.: International Copyright in the 1980s, Geiringer Memorial Lecture 1980,28 Bulletin of the Copyright society of the USA 351 (1981)

Stojanovic, M.N.: The raison d'être of Copyright, 102 RIDA 124 (1979)

Strowel, A.: Considérations sur le droit d'auteur à la lumière des intérêts sous-jacents, in: Droit positif, droit comparé et histoire du droit, Vol. 3 in the series Droit et Intérêt (Brussels, Facultés universitaires Saint Louis, Vol. 49, 1990)

Tompson, R.S.: Scottish Judges and the Birth of British Copyright, The Juridical Review, Part 1 (1992) 18

Tournier, $A .:$ Le bilan de la loi (An Appraisal of the Law), XIX RIDA 79 (1958)

Tournier, J.-L.: Le droit exclusif du compositeur de musique: réalité ou fiction (The Sole Rights of the Composer: Reality or Fiction?), XXXIII RIDA 20 (1961) 
Tyerman, B.W.: The Economic Rationale for Copyright Protection for Published Books: A Reply to Professor Breyer, 18 UCLA Law Rev. 1100 (1971)

Uchtenhagen, U.: The Economic Significance of Copyright, 1989 Copyright 280

Ulmer, E.: Lettre d'Allemagne, 1955 Le Droit d'Auteur 154 Ulmer, E.: Lettre d'Allemagne, 1956 Le Droit d'Auteur 180 Ulmer, E.: Lettre d'Allemagne, 1957 Le Droit d'Auteur 12 Ulmer, E.: Lettre d'Allemagne, 1958 Le Droit d'Auteur 171 Ulmer, E.: Lettre d'Allemagne, 1961 Le Droit d'Auteur 12 Ulmer, E.: Letter from Germany, 1965 Copyright 275 Ulmer, E.: The Federal Republic of Germany and the Berne Union, 1986 Copyright 83

Vaver, D.: Intellectual Property Today: of Myths and Paradoxes, LXIX The Canadian Bar Review 98 (1990)

Vilbois, J.: Historical Account, XIX RIDA 41 (1958)

Vinje, T.C.: A Brave New World of Technical Protection Systems: Will there Still be Room for Copyright? [1996] 8 EIPR 431

Vogel, M.: Urhebervertragsrechtsprobleme am Ende des 18. Jahrhunderts, in: Herschel, W., Hubmann, H. \& Rehbinder, M., (Eds.) FS Georg Roeber zum 10. Dezember 1981, at 423 (Freiburg, HochschulVerlag 1982)

Vogel, M.: Die Geschichte des Urheberrechts im Kaiserreich, 12 GRUR (1987) 873 
Voge1, M.: Urheberrecht in Deutschland zwischen Aufklärung und Vormärz, Beilage zum Bbl. Nr.77 Buchhandelsgeschichte (1989) 96

Vogel, M.: Urheberpersönlichkeitsrecht und Verlagsrecht im letzten Drittel des 19. Jahrhunderts, 8/9 GRUR (1994) 587.

Woodmansee, M.: The Genius and the Copyright: Economic and Legal Conditions of the Emergence of the Author, 17 Eighteenth Century Studies (1984) 425 at 434 .

Yen, A.C.: Restoring the Natural Law: Copyright as Labor and Possession, 51 Ohio State Law Journal, No. 2 (1990)

Other Material - Governmental Reports, Parliamentary Proceedings, Landmark Cases, etc.

\section{United Ringdom}

Millar v Taylor, [1769] 4 Burr. 201

17 Parliamentary History of England 953 (HL 1774)

Donaldson $v$ Beckett, decision of the House of Lords [1774], reported in Cobbetts Parliamentary History of England, Vol. 17, 1813, at 953

Hansard, UK Parliamentary Records, Vol. 56, 1841

Records of House of Commons, debate on copyright, 2 August 1842

Copyright Commission, The Royal Commissions and the Report of the Commissioners, Presented to both Houses of Parliament by Command of Her Majesty, C-2036, HMSO, London (1878)

Report of the Committee on the Law of Copyright, London, HMSO (1909) 
Decision of the UK House of Lords - Hubbard $v$ Vosper, The Weekly Law Reports, February 18, 1972, at 389

Decision of the UK High Court of Justice, Chancery Division Beloff $v$ Pressdram Ltd., [1973] RPC 765

Copyright and Designs Law, Report of the Committee to consider the Law on Copyright and Designs (the Whitford Report), HMSO, cmnd 6732 (1977)

Reform of the Law relating to Copyright, Design and Performers' Protection, HMSO, Cmnd 8302 (1981)

Making a Business of Information, Cabinet office Publication (1983)

Intellectual Property Rights and Innovation, HMSO, Cmnd 9117 (1983)

Recording and Rental of Audio and Video Copyright Material, HMSO, Cmnd 9445 (1985)

Information Society: Agenda for Action in the UK, Report of the House of Lords Select Committee on Science and Technology, HL Paper 77, Session 1995-96, 5th. Report, July 1996.

\section{United states of America}

Decision of the US Supreme Court, Wheaton and Donaldson $V$ Peters and Grigg, 33 US 591 (8 Pet.) 591 [1834]

Report of the Register of Copyrights on the General Revision of the US Copyright Law, Report to the House Committee on the Judiciary, 87th Cong., 1st Sess. (1961)

Report of the House of Representatives Committee on the Judiciary, HR Rep. No. 94-1476, 94th Cong., 2nd Sess. (1976) 
An Analysis of Computer and Photocopyright Copyright Issues from the Point of View of the General Public and the Ultimate Comsumer, National Commission (USA) of New Technological Uses of Copyright Works (CONTU) (June 1977)

Performance Rights in Sound Recordings, House Committee on the Judiciary (Print No. 15), 95th Cong., 2nd Sess. (1978)

The Impact of Copyright Law on the Economy, study prepared by the US Central Bureau of Statistics, February 26, 1982

Report of the United States Copyright Office to the Subcommittee on Patents, Copyright and Trademarks, Committee on the Judiciary, United States Senate, on the Size of the Copyright Industries in the United States, December 1984

Lasercomb America Inc. $v$ Job-Reynolds et al., 1990 Trade Regulation Reports, at $64 \& 289$

Fogerty v Fantasy, Inc., 114 S. Ct. 1023 [1994]

National Information Infrastructure Task Force, Working Group on Intellectual Property Rights, Chair: Bruce A. Lehman, September 1995 .

\section{France}

Commission de la propriété littéraire, collection des procèsverbaux, président Le Vicomte de la Rochefoucauld, Paris, Imprimerie de Pillet Ainé, 1826

Commission de la propriété littéraire et artistique, Rapports à l'Empereur, Décrets, collection des procès-verbaux, Paris, Imprimerie Impériale, 1863

Archives Parlementaires de 1787 à 1860, Receuil complet des débats législatifs et politiques des Chambres françaises (Paris, Paul Dupont 1887) 
IRPI - Institut de recherche en propriété intellectuelle Henri Desbois, Dossier documentaire, Travaux préparatoires, Loi no. 57298 du 11 mars 1957 sur la propriété littéraire et artistique, Paris, Université Pantheon-Assas (Paris II)

IRPI - Institut de recherche en propriété intellectuelle Henri Desbois, Dossier documentaire, Travaux préparatoires, Loi no. 85660 du 3 juillet 1985 relative aux droits d'auteurs et aux droits des artistes interprètes, des producteurs de phonogrammes et de vidéogrammes et des entreprises de communication audiovisuelle, Tomes 1 et 2, Paris, Université Pantheon-Assas (Paris II)

"Industrie Culturelle et Nouvelle Technique", Report of the Committee chaired by Pierre Sirinelli, Ministère de la Culture et de la Francophonie, Paris, 1994.

\section{Germany}

Report in 1888 Le Droit d'Auteur 111

Entwurf und Begründung eines Gesetzes, betreffend das Urheberrecht an Werken der Literatur und der Tonkunst, 8. Dezember 1900, Nr. 97, Reichstag, 10. Legislatur Periode, II. Session, 1900/1901

Bericht der XI. Kommission über den Entwurf eines Gesetzes, betreffend das Urheberrecht an Werken der Literatur und der Tonkunst, No. 214, Reichstag, 10. Legislatur Periode, II. Session $1900 / 1901$

Report in 1901 Le Droit d'Auteur 94

Report in 1927 Le droit d'auteur 101

L'Union internationale au seuil de 1935, Étude générale, 1935 Le Droit d'Auteur 4 
Decision of the Federal Constitutional Court - Kirchen- und Schulgebrauch, 1972 GRUR 481

Decision of the Federal Constitutional Court - Bibliotheksgroschen, 1972 GRUR 485

Decision of the Federal Constitutional Court - Schulfunksendungen, 1972 GRUR 487

Decision of the Federal Constitutional Court - Tonbandvervielfältigungen, 1972 GRUR 488

Decision of the Federal Constitutional Court - Schallplatten, 1972 GRUR 491

Decision of the Federal Constitutional Court - School Book, 3 IIC 394 (1972)

Veranstaltungen von Kirchenmusik, 84 UFITA, 317 (1974)

Decision of the Federal Supreme Court - Photocopies, 10 IIC 265 (1979)

\section{other}

Impact of Copyright Law on the Economy of Sweden, Stockholm, Central Bureau of Statistics, 1982

From Gutenberg to Telidon: A White Paper on Copyright, Ottawa, Consumer and Corporate Affairs Canada and Department of Communications, 1984

Copyright - An Economic Perspective, study prepared by the Australian Copyright Council, Sydney 1987

Competition Policy and Intellectual Property Rights, OECD Study, 1989 
UNESCO Third Medium-Term Plan (1990-1995), adopted in November 1989

Memorandum of the International Bureau of WIPO on Questions concerning a possible Protocol to the Berne Convention, document $\mathrm{BCP} / \mathrm{CE} / \mathrm{I} / 3$, October 1991

Report of the Committee of Experts on a Possible Protocol to the Berne Convention for the Protection of Literary and Artistic Works, second session, Geneva, 10 to 18 February, 1992

Green paper on Copyright and Related Rights in the Information Society, presented by the Commission of the European Communities, Brussels, 19 July 1995 (COM (95) 382 final).

Documents of the Committee of Experts on a Possible Protocol to the Berne Convention, first to sixth sessions, 1991 to 1996.

Documents of the Committee of Experts on a Possible Instrument for the Protection of the Rights of Performers and Producers of Phonograms, first to fifth sessions, 1991 to 1996.

Europe's Way to the Information Society, An Action Plan, Communication of the Commission to the Council and the European Parliament, (COM (94) 347 final) 19 July 1994.

The Challenge of the Information Highway, Final Report of the Information Highway Advisory Council, Canada, 1995. 